\title{
Persoonlijke vaardigheidstherapieen voor kansarmen
}

Citation for published version (APA):

Beckers, B. M. C. (1986). Persoonlijke vaardigheidstherapieen voor kansarmen. [Doctoral Thesis, Maastricht University]. Swets \& Zeitlinger. https://doi.org/10.26481/dis.19860502bb

Document status and date:

Published: 01/01/1986

DOI:

10.26481/dis.19860502bb

Document Version:

Publisher's PDF, also known as Version of record

\section{Please check the document version of this publication:}

- A submitted manuscript is the version of the article upon submission and before peer-review. There can be important differences between the submitted version and the official published version of record.

People interested in the research are advised to contact the author for the final version of the publication, or visit the DOI to the publisher's website.

- The final author version and the galley proof are versions of the publication after peer review.

- The final published version features the final layout of the paper including the volume, issue and page numbers.

Link to publication

\footnotetext{
General rights rights.

- You may freely distribute the URL identifying the publication in the public portal. please follow below link for the End User Agreement:

www.umlib.nl/taverne-license

Take down policy

If you believe that this document breaches copyright please contact us at:

repository@maastrichtuniversity.nl

providing details and we will investigate your claim.
}

Copyright and moral rights for the publications made accessible in the public portal are retained by the authors and/or other copyright owners and it is a condition of accessing publications that users recognise and abide by the legal requirements associated with these

- Users may download and print one copy of any publication from the public portal for the purpose of private study or research.

- You may not further distribute the material or use it for any profit-making activity or commercial gain

If the publication is distributed under the terms of Article $25 \mathrm{fa}$ of the Dutch Copyright Act, indicated by the "Taverne" license above, 


\section{PERSOONLIJKE \\ VAARDIGHEIDSTHERAPIEEN \\ VOOR KANSARMEN}





\section{PERSOONLIJKE VAARDIGHEIDSTHERAPIEEN VOOR KANSARMEN}

\section{PROEFSCHRIFT}

ter verkrijging van de graad van doctor in de Sociale Wetenschappen

aan de Rijksuniversiteit Limburg te Maastricht, op gezag van de Rector Magnificus, prof. dr. F.I.M. Bonke, volgens het besluit van het College van Dekanen in het openbaar te verdedigen in de Aula van de Universiteit op vrijdag 2 mei 1986, des namiddags om 16.00 uur

door

BARBARA MARIA CATHERINA BECKERS

geboren te Heugem, Maastricht

SWETS \& ZEITLINGER B.V. / LISSE 1986 


$\begin{array}{lll}\begin{array}{l}\text { Promotor } \\ \text { Co-promotor }\end{array} & : & \text { Prof. Dr. J.J.C.B. Bremer } \\ \text { Referenten } & : \quad & \text { Dr. R.J.M. Beekers } \\ & & \text { Prof. Dr. R.W.F. Diekstra } \\ & \text { Prof. Dr. H. Philipsen } \\ & \text { Prof. Dr. M.A.J. Romme }\end{array}$

Het onderzoek werd uitgevoerd in het kader van een samenwerkingsproject tussen de Rijksumiversiteit Limburg gevestigd te Maastricht, de RIAGG Maastricht en omstreken gevestigd te Maastricht, de RIAGG Oostelijke Mijnstreek gevestigd te Heerlen, en de Toneelacademie gevestigd te Maastricht.

\section{CIP-GEGEVENS KONINKLIJKE BIBLIOTHEEK}

\section{Beckers, Barbara Maria Catherina}

Persoonlijke vaardigheidstherapieën voor kansarmen / Barbara Maria Catherina Beckers. - Lisse : Swets \& Zeitlinger Onderzoek in het kader van een samenwerkingsproject tussen de Rijksuniversiteit Limburg, de RIAGG Maastricht en omstreken, de RIAGG Oostelijke Mijnstreek en de Toneelacademie te Maastricht. - Proefschrift Maastricht.

- Met lit. opg. - Met samenvatting in het Engels.

ISBN $90-265-0707-0$

SISO 607.29 UDC $615.851-052-058.14(043.3)$

Trefw.: psychotherapie ; kansarmen.

\section{Typewerk: Isel van Noppen}

Omslag ontwerp H. Veltman

Gedrukt bij Offsetdrukkerij Kanters B.V., Alblasserdam

(-) Copyright 1986 B. Beckers en Swets \& Zeitlinger

\footnotetext{
Alle rechten voorbehouden. Niets uit deze uitgave mag worden verveelvoudigd, opgeslagen in een gea utomatiseerd gegevensbestand, of openbaar gemaakt, in enige vorm of op enige wijze, hetzij elektronisch, mechanisch, door fotokopieën. opnamen, of op enige andere manier, zonder voorafgaande schriftelijke toestemming van de uitgever.

All rights reserved. No part of this publication may be reproduced stored in a retrieval system or transmitted, in any form or by any means, electronic, mechanical, photocopying, recording, or owherwise, without the prior witien permission of the publisher.
} 
Deel I. Ontwikkeling van een serie persoonlijke vaardigheidstherapieën voor kansarme geestelijke gezondheidszorg clienten

1. Gestructureerde vaardigheidstherapieën voor clienten uit de lagere sociaal-economische klassen 3

1.1. Inleiding 3

1.2. Psychotherapie en sociaal-economische $k 1$ asse

1.3. Recente ontwikkelingen in de psychotherapeutische hulpverlening aan clienten uit de lagere sociaal-economische $\mathrm{k} 1$ assen

1.3.1. Stand van zaken in de Verenigde Staten 8

1.3.2. Stand van zaken in Nederland 9

1.3.3. Ontwikkelingen in Zuid-Limburg 12

1.4. Beschrijuing van de door Goldstein ontworpen methode. 13

1.4.1. De vaardigheden 14

1.4.2. Modeling 16

1.4.3. Gedragsoefening 18

1.4.4. Bekrachtiging 18

1.4.5. Transfertraining 19

1.5. De Maastrichtse variant 20

1.5.1. Ontwikkeling van een aangepast pakket vaardigheden 20

1.5.2. Productie van video-programma's 21

1.5.3. Ontwikkeling van therapie-protocollen 22

1.5.4. Bandura's "self-efficacy" theorie als theoretisch verk 1 aringsmodel 24

1.5.5. Effectiviteit van de Maastrichtse variant 24

1.6. Persoonlijke vaardigheidstherapieën 25 
2. Beschrijwing van de wijze warop de inhoud van de persoon1ijke vaardigheidstherapieën werd bepald

2.1. Inleiding

2.2. Goldsteiln's ontwerp

2.3. De in Mastricht ontwikkelde serie persoanlijke vaardigheden

2.3.1. "Dagel ijkse problemen aanpakken"

2.3.2. "Veranderingen aanpakken"

2.3.3. "Bes1 issingen nemen"

2.3.4. "Informatie verzamelen"

3. Beschrijving van de wijze waarop de persoonlijke vaardigheids therapieprogramma's worden uitgevoerd

3.1. Inleiding

3.2. Operationalisatie van de basiscomponenten uit Goldstein's methode

3.2.1. Modeling

3.2.1.1. Video-modeling

$3.2,1.2$. Modeling in levende 1 ijuve

3.2.2. Gedragsoefening

3.2.2.1. Gedragsoefening met behulp van standaardsituaties

3.2.2.2. Schriftelijke gedragsoefening

3.2.2.3. Anticiperende gedragsoefening

3.2.2.4. Reconstruerende gedragsoefening

3.2.2.5. Gedragsoefening in spelvorm

3.2.3. Bekrachtiging

3.2.3.1. Bekrachtiging door relevante anderen

3.2.3.2. Zelfbekrachtiging

3.2.4. Transfertraining

3.2.4.1. Huiswerkopdrachten

3.2 .4 .2 . Huiswerkboekjes

$3 \cdot 2 \cdot 4 \cdot 3$. Bepaling van "herinneringssignalen"

3.3. Indicaties voor deelname

3.3.1. "Dagelijkse problemen aanpakken"

3.3.2. "Veranderingen aanpakken"

3.3.3. "Beslissingen nemen" 
3.4. Algemene richtlijnen woor therapeuten

3.5. De relatie tussen persoanlijke en interpersoonlijke vaardigheidstekorten

3.6. "Impliciete" leerpunten 77

3.7. Protocallen voor therapeuten

4. Plaats van de persoonlijke vaardigheidstherapieên à la Goldstein in het totale veld van de cognitieve gedragstherapie

4.1. Inleiding

4.2. Beknopte inhoudelijke typering van de cognitieve gedrags therapie

4.3. De cognitieve gedragstherapie ingedeeld in drie categorieën

4.3.1. Cognitieve herstructurering.

4.3.2. Coping-skil1s-therapleën

4.3.3. Problem-solving-therapieën

4.4. De persoonlijke vaardigheidstherapleën à la Goldstein als een vorm van cognitieve gedragstherapie

4.5. Kanttekeningen bij de cognitieve ontwikkelingen in de gedragstherapie

Dee 1 II. Theoretische aspecten

5. A1gemeen theoretische ontwikkelingen en hun implicaties voor vaardigheidstherapileën

5.1. Inleiding

5.2. De opkomst van cognitieve verklaringsmodellen ten aanzien van de wijze waarop leerprocessen verlopen in vogelvlucht beschreven

5.3. Keuze van 3 relevante verk1aringsmodellen

5.3.1. Het cognitief sociaal-1eertheoretisch model van Rotter

5.3.1.1. Beschrijuing van het mode1 
5.3.2. Het cognitief sociaal-leertheoretisch model van Bandura

5.3.2.1. Beschrijuing van het model

5.3.2.2. Implicaties voor valardigheids therapieën

5.3.3. Het stressmodel van Lazarus

5.3.3.1. Beschrijuing van het model

5.3.3.2. Relevantie ten aanzien van vaardigheidstherapieenn

5.4. Constructile van een geintegreerd cognitief sociaal-leertheoretisch madel

5.5. De uitvoering van de vaardigheidstherapieën à la Goldstein beschreven vanult een cognitief sociaal-leertheoretisch perspectief

5.5.1. Verhoging en generalisatie van de persoonlijke competentie-verwachtingen

5.5.2. Optimalisering van de respons-uitkomst-verwachtingen

Deel III. Empirisch onderzoek naar de effecten van persoonl ijke vaardigheidstherapieën bij kansarme geestelijke gezandheidszorg $\mathrm{clienten}$

6. Antwikkeling van een evaluatie-instrument

6.1. Inleiding

6.2. Li teratuuroverzicht

6.3. Constructite van de items

6.4. Opzet van het onderzoek naar de psychometrische eigenschappen van de DH-1 ijst

6.4.1. Proefgroep en procedure

6.4.2. Resul taten factor-analyse

6.4.2.1. DH-subschaal 1. "Vertrouwen in eigen

probleemoplossingsvaardigheid"

6.4.2.2. DH-subschaa1 2. "Plannen maken en vooruit denken"

6.4.2.3. DH-subschaal 3. "Consequent handelen"

6.4.3. Betrouwbaarheid en stabiliteit van de 3 subschalen 130

6.4.4. Correlaties tussen de $3 \mathrm{DH}$-subschalen onderling 
6.4.5. Bepaling van de divergerende validiteit

6.4.6. Invloed van demografische variabelen op de vragenlijstscores

6.5. Samenvatting en conclusies ten aanzien van de DH-lijst

7. Effecten van persoonlijke vaardigheidstherapieën

7.2. Opzet van effectiviteitsonderzoek

7.3. Effectiviteitscriteria en meetinstrumenten

7.3.1. Uitbreiding van het "vertrouwen in eigen probleemoplossingsvardigheid" $\left(\mathrm{DH}_{1}\right)$

7.3.2. Verandering ten aanzien van "plannen en vooruitdenken" $\left(\mathrm{DH}_{2}\right)$

7.3.3. Verandering ten aanzien van "consequent handelen" $\left(\mathrm{DH}_{3}\right)$

7.3.4. Verandering in locus of control

7.3.5. Vergroting van zelfwardering

7.3.6. Vermindering van rigiditeit

7.3.7. Verandering in copingstijlen

7.4. Proefpersonen

7.4.1. Experimentele groep

146

7.4.2. Controlegroep

7.5. Dataverzame 1 ing

7.5.1. Wijze van dataverzameling

7.5.2. Tijdstippen van dataverzameling

7.6. Dataverwerking en resultatem

7.6.1. Effecten ten aanzien van "vertrouwen in eigen probleemoplossingsvaardigheid" $\left(\mathrm{DH}_{1}\right)$

7.6.2. Effecten ten aanzien van "plannen en vooruitdenken" $\left(\mathrm{DH}_{2}\right)$

7.6.3. Effecten ten aanzien van "consequent handelen" $\left(\mathrm{DH}_{3}\right)$

7.6.4. Effecten ten aanzien van lacus of control

7.6.5. Effecten ten aanzien van zelfwaardering

7.6.6. Effecten ten aanzien van rigiditeit

7.6.7. Effecten ten aanzien van copingstijlen

7.6.8. Effecten bij herhaalde nameting na een jaar 
8. Conclusies en discussie 164

8.1. Inleiding 164

8.2. Psychotherapie met $c l$ ienten uit de lagere sociaaleconomi sche $k$ lassen $\quad 164$

8.3. Persoonlijke en interpersoonlijke vaardigheidstherapieën 165

8.4. De cognitieve ontwikkelingen in de gedragstherapie 167

8.5. Het geintegreerd cognitieve sociaal-1eertheoretische $\begin{array}{ll}\text { model } & 169\end{array}$

8.6. Het effectiviteitsonderzoek 172

8.7. De wijze waarop de persoonlijke vaardigheidstherapieën worden uit tgevoerd

Bijlage I. Protocol voor de vaardigheid "Dagelijkse problemen a anpakken"

II. Protocol voor de vaardigheid "Veranderingen a anpakken"

IV. Biografische gegevens proefgroep onderzoek DH-1ijst

Nawoord 
"Psychotherapy is most effective for those who need it the least and least effective for those who need it the most ${ }^{\text {II }}$ (Goldberg, 1966).

"Die Trennung von Gesellschaft und Psyche ist falsches Bewusstsein: sie verewigt kategorial die Entzweiung des lebendigen Subjects und der von ihnen herrührende objectivität" (Adorno, 1955). 
Sinds 1977 steit het Maastrichtse Goldsteinproject zich ten doel een bijdrage te leveren aan de psychotherapeutische hulpveriening aan clienten uit de lagere sociaal-economische klassen: de kansarmen in de geestelijke gezondheidszorg. In 1976 introduceerde de door de Nederlandse Instituten voor Multidisciplinaire Psychotherapie (afgekort IMP-en) opgerichte Stuurgroep Maatschappelijke Spreiding het begrip LIBO-client als formele omschrijuing voor de (psycho)therapie-client, afkomstig uit de lagere sociaal-economische klassen. De term LIBO vormt de afkorting van Lager Inkomen, Beroepsstatus en opleidingsniveau.

De projectgroep besloot een voor Nederland aangepaste versie te ontwikkelen van de "structured learning therapy". Deze door Arnold Goldstein (1973) ontworpen methode is gebaseerd op principes uit de sociale leertheorie (Bandura, 1966) en maakt gebruik van gedragstherapeutische procedures zoals modeling, gedragsoefening, (sociale) bekrachtiging en transfertraining. De Goldsteinmethode is een kortdurende, directieve groepstherapie gericht op het aanleren van hetzij interpersoonlijke, hetzij persoonlijke vaardigheden. De gehanteerde psychotherapeutische leermethode sluit aan aan de levensstijl, behoeften, gedragskenmerken en psychologische efigenschappen van clienten afkomstig uit de lagere sociaal-economische klassen.

De eerste fase van het project betrof de ontwikkeling en evaluatie van een reeks interpersoonlijke vaardigheidstherapieën, zoals beschreven in "Interpersoonlijke vaardigheidstherapieën voor kansarmen" (Beekers 1982).

De tweede fase, waarvan verslag wordt gedaan in deze studie, had betrekking op de ontwikkeling en evaluatie van een serie persoonlijke vaardigheidstherapieën voor dezelfde doelgroep.

Het proefschrift dat nu voor u 1igt, is uit vier delen apgebouwd. Deel I beschrijft de ontwikkeling van een serie persoonlijke vaardigheidstherapieên voor clienten uit de lagere sociaal-economische klassen. Deel I omvat hoofdstuk 1 tot en met 4 . 
Hoofdstuk 1 beschrijft de ontwikkeling wan de "structured learning therapy (A. Goldstein, 1973) als mogelijk antwoord op de alom te constateren problemen in de psychotherapeutische hulpverlening aan clienten uit de lagere social-economische klassen. ook wordt de door de Mastrichtse Goldsteimprojectgroep ontwikkelde variant op deze methode beschreven. Hoofdstuk 2 besteedt andacht aan de wijze warop de inhoud van de serie persoonlijke valardigheldstherapieän tot stand kwam. In hoofdstuk 3 wordt beschreven op welke wijze de persoonlijke vaardigheidstherapie-programma "s worden uitgevoerd. Hoofdstuk 4 geeft aan wat de plaats is van de persoonlijke vaardigheidstherapieẽn in het totale veld van de cognitieve gedragstherapeutische interventies.

Dee1 II, hoofdstuk 5, besteedt aandacht aan relevante theoretische ontwikkelingen. De implicaties van cagnitief sociaal-leertheoretische verklaringsmodellen voor vaardigheidstherapieën à la Goldstein worden uitvoerig beschreven.

Deel III, hoofdstuk 6 en 7, wormt het verslag van een empirisch onderzoek naar de effecten van persoonlijke vaardigheidstherapieën bij vier subgroepen geestelijke gezondheidszorg-clienten, afkonstig uit de 1agere sociaal-economische klassen.

In deel IV, hoofdstuk 8 , is er ruimte voor conclusies en discussie. In dit hoofdstuk worden de belangrijkste topics uit dit proefschrift samengevat en van discussie voorzien.

Het proefschrift eindigt met een samenvatting, een literatuuroverzicht, een viertal bijlagem en een nawoord en is woorzien van een curriculum vitae van de auteur. 
DEEL I.

ONTWIKKELING VAN EEN SERIE PERSOONLIJJEE VAARDIGHEIDSTHERAPIEEN VOOR KANSARME GEESTELIJKE GEZONDHEIDSZORG CLIENTEN

HDOFDSTUK 1. GESTRUC TUREERDE VAARDIGHEIDSTHERAPIEEN VOOR CLIENTEN UIT DE LAGERE SOCIAAL-ECONOMISCHE KLASSEN

\subsection{INLEIDING}

In dit hoofdstuk zal worden ingegaan op de psychotherapeutische hulpverlening aan clienten uit de lagere sociaal-economische klassem. De door Goldstein (1973) ontwikkelde, speciaal op de psychologische eigenschappen en specifieke leerstijl van deze doelgroep afgestende "structured learning therapy" wordt beschreven. Vervolgens wordt aandacht besteed aan de wijze warop deze methode werd uitgewerkt door de Maastrichtse Goldsteinprojectgroep. Tot slot wordt een eerste omschrijving gegeven van het onderzoeksobject wan dit proefschrift: de persoonlijke vaardigheidstherapieën.

\subsection{PSYCHOTHERAPIE EN SOCIAAL-ECONOMISCHE KLASSE*}

Uit de literatuur blijkt dat er specifieke relaties bestaan tussen sociaal-economische variabelen en indicaties voor psychotherapie (Goldstein, 1973; Lorion, 1973; Jones, 1974). In vergelijking met clienten wit de midden en hogere $k l a s s e n$ worden clienten wit de lagere klassen gekenmerkt door het feit dat ze

- vaker niet geschikt worden geacht voor psychotherapeutische behandeling;

- langer op de wachtlijst blijuen staan;

* Over dit onderwerp werd eerder gepubliceerd: zie Beekers, Beckers, Bongaarts en Peters, 1980. 
- meer kans maken op een ernstiger ziektelabel;

- een minder hechte relatle aangaan met hun therapeut;

- vaker voortijdig met de behandeling stoppen;

- er verwachtingen op na houden met betrekking tot therapie en therapeut, die niet overmeenkomen met de verwachtingen die de therapeut daromtrent heeft:

- vaker toegewezen worden aan de minst ervaren therapeuten;

- bij voorbat een slechtere prognose krijgen;

- zelf niet veel vertrouwen hebben in een positief therapieresultaat.

Mensen uft de lagere sociaal-economische klassen maken nauwelijks gebrulk van bestaande psychotherapeuti sche voorzieningen (Hollingshead en Reditch, 1958; Myers en Bean, 1968; Meltzhoff en Kornreich, 1970; Gleiss, Seidel en Abhoiz, 1973; Goldstein, 1973).

Schoffeld (1964) onderscheidt twee verschillende typen psychotherapie clienten: mister Yavis en mister Hound. De term mister Yavis verwijst naar de door de meeste psychotherapeuten als ideaal ervaren psychotherapieclienten. Yavis varmt de afkorting voor young, attractive, verbal, intelligent, successful. Mister Yavis is het prototype van de client uit de midden en/of hogere sociaal-economische klassen. De afkorting mister Hound typeert de client uit de lagere sociaal-economische klassen. Hij is humble, ordinary, unattractive, naughty en du11. Lorion (1973) constateert dat clienten uit de lagere sociaaleconomilsche $k l$ assen weelal bij voorbaat al ongeschikt worden geacht voor psychotherapeutische behandeling. Brager (1964) constateert eveneens problemen in de psychotherapeutische hulpverlening aan clienten uft de lagere soclaal-economische klassen. Hij wijt deze problemen aan verschlllen in verwachtingspatroon c.q. opstelling tussen therapeut en client. Deze verschillen zijn weergegeven in tabel 1.1 . 
- legt nadruk op zelf doen, zelfverantwoordel ljkheld. ZIJn leuzen zljn: werander Jezelf. Neen zelf de ver antwoordel ijkheld voo de oplassing van je problemen".

- ger lcht op introspectle: denken em woorden.

- werkt ongestructureerd; is zeer permisslefi.

- nadruk op erwarlngen ult het verleden.

- focus op het individu.

- nadruk op Innerlljk comfllicten: anaIyse van overdrachts- en weerstandsfenomenen.

- verkl ar ingen zijn symbol Isch, clrkellvormilg.

- intensleve overdrachts- en tegenoverdrachtsrelaties.
- yraagt on autorltoit dle directleven geeft.

- extrospectlef: voorkeur woor doen, activitient.

- wenst structuur.

- nadruk op siltuatles van mat.

- focus op gezln, famllle, groep.

- nadruk op concrate levensproblemen.

- verkl ar Ingen zlJn cenvoudlig, concret, objectlef on vanzel fsprokend.

- behoefte aran inindor Intensleve rellatles; behoefte an Informele vrlendel IJ kheld en respect: bem noefte am anpathlle.

Auld en Myers (1954), Frank e.a. (1957), Rosenthal en Frank (1958), Bailey e.a. (1959), Cole e.a. (1962), Baekeland en Lundwall (1975) toonden empirisch aan dat clienten uit de lagere sociaal-economische klassen hun psychotherapieën vaker voortijdig beëindigen dan clienten wit de midden en/of hogere $k l$ assen.

De tot nu toe aangehaalde 1 iteratuur bevestigt dat de psychotherapeutische hulpverlening aan clienten uit de lagere sociali-economische klassen veelal problematisch verloopt (zie ook Lorion, 1978). Deze bevinding staat op gespannen voet met het gegeven dat psychische problemen en stoornissen relatief vaker voorkomen in de lagere sociaaleconomische klassen (Hollingshead en Redlich, 1958; Srole, Langer, Michae1, Opler en Rennie, 1962; Dohrenwend en Dohrenwend, 1969). Nijhof (1979) en Ormel (1981) toonden aan dat ook in Nederland geldt dat psychische stoornissen vaker voorkomen in de lagere sociaal-economische klassen.

Ormel (1981) komt tot de conclusie dat voor lager geschoolden geldt dat er zowel sprake is van een zwaardere belasting alsook van een ge- 
ringere belastbaarheid. Nijhof (1979) concludeert dat de wijze waarop men in een bepalde samenleving sociale stratificatie en de daarmee samenhangende ongelijkheid in levensomstandigheden interpreteert, van invloed is op de psychische gezondheid van de individuen die tot de laagste strata behoren. Interpretatie van sociale stratificatie en de daarmee samenhangende ongelijkheid in levensomstandigheden in termen van persoonlijke problemen, vergroot zijn inziens de kans op het tot stand komen van psychische stoornissen. Deze auteur is dus van mening dat individualisering c.q. subjectivering van matschappelijke bepaalde problemen van invloed is op het tot stand komen van psychische stoornissen.

De relevante literatuur overziend, kan men verschillende opvattingen onderscheiden over de wijze warop men de problemen in de psychotherapeutische hulpverlening aan clienten uit de lagere sociaal-economische k1 assen kan verk1 aren.

Een aantal auteurs is van mening dat de negatieve houding - stereotypen en vooroordelen - van psychotherapeuten ten aanzien van clienten uit de lagere sociaal-economische klassen in dit opzicht een belangrijke rol spelen (Heine en Trosman, 1960; Meltzoff en Kornreich, 1970; Lorion, 1973, 1974a, 1974b, 1978). Anderen concluderen dat de negatieve verwachtingen van de client in deze de meest adequate verklaring vormen (Hollingshead en Redlich, 1958; Overall en Aronson, 1963; Aronson en Overa11, 1966). Lorion (1974b) draagt op zijn beurt echter weer onderzoek aan dat met laatstgenoemde conclusie in strijd blijkt. Hij is van mening dat de verwachtingen van clienten uit de lagere sociaalecomonische $k l$ assen ten aanzien van psychotherapie in de loop wan de tijd steeds adequater en realistischer zijn geworden tengevolge van informatieverstrekking via televisie, film, radio en populaire pers (vgl. de protoprofessionaliseringstheorieën van A. de Swaan, 1979) en dat deze verklaring zodoende niet langer opgaat. Brager (1964) is van mening dat de problemen verklaard moeten worden vanuit de interactie therapeut-client. Bij interacties tussen twee individuen afkomstig uit ufteenlopende sociaal-economische klassen spelen verschillen in houding en verwachtingspatronen een belangrijke rol. De auteur is van mening dat dergelijke verschill en aanleiding (kunnen) geven tot proble- 
men in de werkrelatie die tussen therapeut en client tot stand dient te komen. Minuchin (1967), Ryan (1972), Goldstein (1973), Minuchin (1973) zijn van mening dat er, wat de psychotherapeutische hulpverlening aan clienten uit de lagere klassen betreft, vooral sprake is van een methodiek probleem: bestaande methodes - met name psycho-analytisch georienteerd en Rogeriaans - sluiten op geen enkele wijze aan bij de levenstij1, kenmerken, behoeften en psychologische eigenschappen van $\mathrm{clienten}$ afkomstig uit deze klassen.

De tot mu toe besproken 1 iteratuur illustreert dat de problemen in de psychotherapeutische hulpverlening aan clienten uit de lagere sociaaleconomische klassen op verschillende wijzen verklaard kunnen worden. Verschillende soorten verklaringen geven aanleiding tot verschillende soorten oplossingen. De voorgestelde oplossingen betreffen uiteenlopende aspecten van een en hetzelfde probleem. De in dit opzicht relevante variabelen kan men globaliter in vijf categorieën verdelen, te weten:

a. variabelen die de houding, opvattingen, verwachtingen en persoonlijkheid van de therapeut betreffen,

b. variabelen die de houding, opvattingen, verwachtingen en persoonlijkheid van de $c l i e n t$ betreffen,

c. variabelen die de interactie tussen therapeut en client betreffen,

d. variabelen die de levensomstandigheden en sociale positie van de client betreffen,

e. variabelen die de door de psychotherapeut gehanteerde methodiek betreffen.

Het gaat er niet om verdere pogingen te doen het relatieve belang van elk van deze variabelen afzonderlijk vast te stellen en tegen elkaar af te wegen. Veel belangrijker is dat men effectieve en pragmatische oplossingen voor de geconstateerde problemen ontwikkelt en op hun effectiviteit toetst. 
1.3. RECENTE ONTWIKKELIWGEN IN OE PSYCHOTHERAPEUTISCHE HULPVERLENING AAN CLIENTEN UIT DE LAGERE SOCIAAL-ECONOMISCHE KLASSEN

\subsubsection{Stand van zaken $\mathrm{in}$ de Verenigde Staten}

In 1978 constateert Lorion in een door hem geschreven overzichtsartikel dat het duidelijk is dat clienten uit de lagere sociaal-economische $k l a s s e n$ te weinig aan bod komen in de psychotherapeutische hulpverlening. Hij stelt dat het zoeken naar effectieve oplossingen voor de in dit opzicht te constateren probiemen momenteel de hoogste prioriteit verdient. Net als Heine en Trosman (1960), Reiff en Scribner (1964), Riessman (1964), Rlessman e.a. (1964), Schneiderman (1965), Grey (1969), Rubin (1976) is Lorion van mening dat men bij het zoeken naar oplossingen rekening moet houden met de typische levensstij1, kenmerken, behoeften en psychologische eigenschappen van deze groep mensen.

In de Amerikaanse $1 i$ teratuur kan men 4 soorten oplossingen onderscheiden:

a. Pogingen de client uit de lagere $k l$ asse beter voor te bereiden op psychotherapie. Deze voorbereiding kan op verschillende manieren gebeuren. Er kan sprake zijn van direkte instructies, informatieve gesprekken en/of inoefening van adequat therapiegedrag. Heitler (1973, 1976) is van mening dat een betere voorbereiding op psychotherapie de behandelingsresultaten bij clienten uit de lagere sociaal-economische $k l$ assen kan verbeteren.

b. Pogingen de stereotypen en vooroordelen van psychotherapeuten ten aanzien van clienten uit de lagere sociaal-economische $k l a s s e n$ te doen verdwijnen. Jacobs, Charles, Jacobs, Weinstein en Mann (1972) toonden aan dat het doorbreken van negatieve verwachtingen en attitudes van psychotherapeuten vooraf aan behandeling, positievere behandel ingsresultaten tot gevolg heeft.

c. Pogingen de psychotherapeutische methodieken aan te passen aan de psychologisch relevante kenmerken van clienten uit de lagere sociaal-economische klassen. In dit opzicht kan men in de literatuur twee verschillende opvattingen onderscheiden. 
Enerzijjds de auteurs die van mening zijn dat bestaande methodieken - waaronder ook de psychoanalytische benadering - bruikbaar kunnen zijn in het psychotherapeutisch werk met clienten uit de lagere klassen (Gould, 1967; Lerner, 1972; Gleiss, Seidel en Abholz, 1973). Deze auteurs maken daarbij de kanttekening dat men deze technieken dan wel in een aantal pragmatische opzichten - waaronder frequentie en plaats van de zlittingen zowel als totale duur van de behandeling en kostenfactor - dient aan te passen aan de levensstijl en daarmee samemhangende mogelijkheden en beperkingen van de doelgroep.

Anderzijds de auteurs die van mening zijn dat bestaande op inzicht gebaseerde methodes niet geschikt zijn voor het psychotherapeutisch werk met clienten uit de lagere sociaal-economische klassen (Minuchin, 1967; Ryan, 1972; Goldstein, 1973) Deze auteurs zijn van mening dat men nieuwe psychotherapeutische technieken dient te ontwikkelen, speciaal aangepast aan de levensstijl, maatschappelijke omstandigheden en psychologische kenmerken van bedoelde clientgroep.

d. Psychotherapeutische hulpverlening door para-professionals afkomstig uit dezelfde klasse (Cowen, 1973; Sobey, 1970).

Uit de literatuur blijkt (Lorion, 1978) dat elk van deze pogingen tot oplossing van de geconstateerde problemen positieve resultaten oplevert. De beschikbare literatuur geeft geen aanwijzingen voor mogelijke superioriteit van een van deze benaderingen.

\subsubsection{Stand van zaken in Nederland}

In de zeventiger jaren was er, wat de geestelijke gezondheidszorg betreft, sprake van een toenemende belangstelling voor de psychotherapeutische hulpverlening aan clienten uit de lagere sociaal-economische $k$ lassen. Deze belangstelling liep parallel aan een algemene trend in onderwijs en welzijnszorg meer aandacht te besteden aan mensen in zgn. achterstandssituaties.

Het merendeel van de in 1.2 . en 1.3 . aangehalde 11 teratuur heeft be- 
trekking op de Amerikaanse situatie. In deze 1 teratuur wordt het begrip lagere sociaal-economische klasse geoperationaliseerd op de door Hollingshead en Redlich (1958) voorgestelde wijze. De indicatoren met behulp waarvan bepaald wordt tot welke klasse men behoort zijn opleiding, beroep en inkomensniveau.

In 1976 introduceerde de door de Mederlandse Instituten voor Multidisciplinaire Psychotherapie (afgekort IMP-en) opgerichte Stuurgroep Maatschappelijke spreiding het begrip LIBO-cilient als formele omschrijuing voor de (psycho)therapie-client afkomstig uit de lagere sociaal-economische $\mathrm{k} 1$ assen. Bij deze omschrijving worden dezelfde indelingscriteria gehanteerd als door Hollingshead en Redlich (1958), aangepast aan de in Nederl and vigerende maatschappelijke verhoudingen. De term LIBO vormt de afkorting van Lager Inkomen, Beroepsstatus en opleidingsniveau. Lager inkomen verwijst naár een bruto-inkomen beneden de ziekenfondsgrens. Het nombedrag voor deze grens is de laatste 10 jaar sterk verhoogd. Voor 1984 bedroeg deze grens $f 47.850$,- bruto per jaar. Lagere beroepsstatus houdt in dat men werkzaam is als arbeider of als lagere employè. Lager onderwijsniveau impliceert lager onderwijs plus maximal 3 jaar vervolgonderwijs.

op basis van beschikbare gegevens kwam de bovengenoemde stuurgroep in 1976 tot de inschatting dat de totale werkende bevolking van Nederland voor 35 à $45 \%$ uit LIBO's bestaat. Ook kwam men tot de conclusie dat LIBO's ondervertegenwoordigd waren in het $c$ lientenbestand van de eerder genoemde IMP-en*. Van de IMP-clienten bleek slechts 3 à $4 \%$ tot de LIBO-categorie te behoren.

Door Hollingshead en Redlich (1958) en Lorion (1973, 1978) wordt de totale groep clienten afkomstig wit de lagere sociaal-economische $k 1$ assen in twee subgroepen verdeeld, te weten de "blue collar workers" en "the poor". De eerder genoemde Nederlandse Stuurgroep doet geen uitspraken over een dergelijke onderverdeling. De indruk bestaat dat

* Ten gevolge van structuurveranderingen in de geestelijke gezandheidszorg - de zogenaamde RIAGG-vorming - zijn de IMP-en inmiddels opgeheven en zijn er OEP-en (Organisatorische Eenheden voor Psychotherapie) in elke RIAGG gevormd. RIAGG vormt de afkorting voor Regionale Instellingen Ambul ante Geestel ijke Gezondheidszorg. 
er ook in Nederland sprake is van een dergelijke tweedeling, warbij bovendien opgemerkt kan worden dat individuen behorend tot de allerlaagste groep, vrijwel niet bij de bestaande instellingen voor geestelijke gezondhelidszorg over de drempel komen.

De Stuurgroep Maatschappelijke Spreiding van de Psychotherapie koos, wat de psychotherapeutische behandeling van clienten uit de lagere sociaal-economische klassen betreft, voor een zogenaamd "retro-discriminatoir" beleid. Dit betekent dat men ernaar streefde ongewenste sociale selectie-effecten, zoals die bij de psychotherapeutische behandeling van LIBO-clienten een rol spellen, ongedaan te maken. Men streefde posittleve discriminatie van LIBO-c1lenten na. De Stuurgroep ging, in navolging van Gould (1967), Lerner (1972), Gleiss, Seidel en Abholz (1973), Willems (1976) wit van de vooronderstelling dat bestaande op inzicht georiënteerde psychotherapiemethodes brulkbaar kunnen worden gemaakt voor het psychotherapeutisch werk met clienten uit de lagere klassen. De Stuurgroep beoogde bestaande stereotypen en vooroordelen met betrekking tot de psychotherapeutische hulpverlening aan deze doelgroep te doen verdwijunen.

Naast de door de Stuurgroep gepropageerde oplossingen kon men hier ten 1 ande twee tendenzen in andere richting onderscheiden. Pijpe (1976) en Stufkens (1977) werkten voorbereidingsprogramma's uit die ten doel hadden clienten uit de lagere sociaal-economische $k l$ assen beter voor te bereiden op psychotherapie. Van der Velden (1977), Beekers e.a. (1980), Mei1lo en Goedhart (1980) streefden ernaar psychotheraplemethodes te ontwikkelen, aangepast an en afgestemd op de specifieke levensstij1, behoeften en psychologische kenmerken van deze doelgroep. Samenvattend $k a n$ men dus stellen dat men ten aamzlien van de psychotherapeutische hulpverlening aan clienten uit de lagere sociaal-economische kiassen in Nederland globaal gezien dezelfde ontwikkelingen kan onderscheiden als in de Verenigde staten, zij het met de uitzondering dat het psychotherapeutisch werk met para-professionals afkomstig uit dezelfde $k$ lasse in Nederland tot nog toe niet systematisch ontwikkeld werd. 
Eind 1977 werd er in Mastricht een projectgroep geformeerd die bestond uit medewerkers van de Rijksuniversiteit Limburg, de RIAGG Maastricht en omstreken, de RIAGG Oostelijke Mijnstreek en de Toneelacademie Maastricht. Aanlefding tot de formatie van deze projectgroep vormde de bif beide RIAGG's gesignaleerde problemen in de psychotherapeutische hulprerlening aan clienten utt de lagere sociaal-economische kT assen.

Uit beschikbaar registratiemateriaal bleek dat voor de Maastrichtse RIAGG gold dat mindergeschoolden en mensen met lagere inkomens ruim vertegenwoordigd waren in het $\mathrm{clientenbestand} \mathrm{(Beekers,} \mathrm{1982).} \mathrm{Ge-}$ sprekken met hulpverleners verbonden aan deze instelling leidden tot de conclusie dat men behoefte had aan uitbreiding van beschikbare hulpverleningstechnteken. Men was van mening dat het ontwikkelen van een aan de elgenschappen en mogelijkheden wan de clienten uit de lagere sociaal-economische $k$ lassen angepaste hulpverleningsmethodiek de kwaliteit van de hulpverlening aan deze clientgroep ten goede zou komen. Aansluitend aan deze behoefte, besloot de projectgroep een aan de doelgroep aangepaste psychotherapiemethode te gaan ontwikkelen. Het werk van Goldstein (1973) bleek in deze een adequaat uitgangspunt te kunnen vormen. De door deze auteur uitgewerkte psychotherapiemethode is gebaseerd op een zijns inziens fundamenteel verschil in leerstij1 tussen mensen wit de midden en/of hogere $k l$ assen en mensen wit de lagere klassen.

Tabel 1.2. geeft de wiljze weer waarop Goldstein (1973) dit verschi1 typeert.
Tabel 1.2. Verschil In leerstlJ| tussen monsen atkonstlg ult de lagere soclab-aconomlsche klassien en mensien afkomstlig ult mididen en/of hogere kllassen

\begin{tabular}{|c|c|}
\hline $\begin{array}{l}\text { MI dden/Hogere kl asse } \\
\text { Leerst IJI gekenmerkt door: }\end{array}$ & $\begin{array}{l}\text { Lager klasse } \\
\text { Leerstijl gekennerkt door: }\end{array}$ \\
\hline $\begin{array}{l}\text { nedruk op: } \\
\text { - Intentles } \\
\text { - empathle } \\
\text { - zel fcontrole }\end{array}$ & $\begin{array}{l}\text { nodruk op: } \\
\text { - gevolgen, resultaten } \\
\text { - actlie } \\
\text { - externe autorltelt }\end{array}$ \\
\hline
\end{tabular}


Op basis van uitgebreid literatuuronderzoek komt Goldstein tot de conclusie dat aan de leerstijl van de lagere sociaal-economische klassen aangepaste psychotherapiemethodes aan de volgende eisen moeten voldoen:

- ze moeten kortdurend, direktief en gestructureerd van aard zijn;

- de nadruk moet liggen op het aanleren van concrete gedragingen: ski11s of vaardigheden genoend;

- als leemethode moet men gebruik maken van modeling, instructie, gedragsoefening, transfertraining, (sociale) bekrachtiging;

- het aanleren van vaardigheden moet bij voorkeur groepsgewijs gebeuren;

- tijjdens de groepsbijeenkomsten moet(en) de therapeut(en) eenvoudige, duidel ijke, op LIBO-clienten afgestende, taal spreken. Ingewikkelde abstracties dient men zoveel mogelijk te vermijden. Humor moet een plaats hebben binnen de therapie.

De in navolging van Goldstein door de Maastrichtse projektgroep ontwikkelde vaardigheidstherapieën zijn erop gericht clienten uit de lagere sociaal-economische klassen effectiever te leren omgaan met de eisen die het dagelijks leven aan hen stelt. Men leert hen de in hun levenssituatie aamwezige ruimte tot zelfcontrole en zelfbepaling beter waar te nemen en adequater te benutten, hetgeen tot gevolg zal hebben dat de zelfwaardering van de betreffende individuën versterkt wordt.

1.4. BESCHRIJVING VAN DE DOOR GOLDSTEIN ONTWORPEN METHODE*

In 1973 verscheen het door Goldstein geschreven boek "Structured Learning Therapy, toward a psychotherapy for the poor". Hij beschreef daarin voor het eerst de door hem ontwikkelde vaardigheidstherapieën voor clienten ult de lagere sociaal-economische $\mathrm{klassen.} \mathrm{De} \mathrm{methode} \mathrm{is}$ gebaseerd op leertheoretische principes. Men streeft ernaar clienten

* Over dit onderwerp werd eerder gepubliceerd: zie Beekers, Beckers, Bongaarts en Peters, 1980. 
concrete gedragingen - ook wel vaardigheden of skills genoemd - aan te leren door middel vam modeling, gedragsoefening, (sociale) bekrachtiging en transfertraining. Men werkt in groepen die, afhankelijk van de aan te leren vaardigheden, 3 tot 15 keer bij elkaar komen. De trefwoorden directief, gestructureerd en kortdurend kenmerken de methode. In het nu volgende zullen de vaardigheden alsook de gehanteerde leertheoretische principes elk af zonderlijk worden beschreven.

\subsubsection{De vaardigheden}

In 1976 beschreef Goldstein 59 verschillende vaardigheden opgesplitst In 37 "basisvaardigheden" en 22 "toepassingsvaardigheden" (=application ski11s).

onder een skill (vaardigheid) verstat Goldstein een nauwkeurig omschreven doelgedrag geoperationaliseerd als een - veelal chronologisch geordende - sequentie van concreet omschreven deelgedragingen. De "basisvaardigheden" kan men opdelen in een serie interpersoonlijke vaardigheden en een serie persoonlijke vaardigheden.

Elke basisvaardigheid wordt geoperationaliseerd met behulp van leerpunten variërend in aantal van 3 tot 7 per vaardigheid. Hier volgt een voorbeeld van een interpersoonlijke basisvaardigheid met leerpunten (in letterlijke vertaling):

Vaardigheid 1.: Een gesprek beginnen

Leerpunten

1. Kies de juiste plaats en tijd

2. Groet de ander

3. Praat over koetjes en kalfjes

4. Ga na of de ander luistert en met je wil praten

5. Snij het onderwerp aan waar je het over wilt hebben.

De interpersoonlijke basisvaardigheden hebben betrekking op de interacties van het individu met anderen. De persoonlijke basisvaardigheden betreffen de wijze waarop het individu zijn dagelijks leven structureert. Bij deze vaardigheden ligt de madruk op het aanleren van overt gedrag. 
Goldstein e.a. (1976) presenteerden de interpersoonl ijke basisvaardigheden aanvankelijk in 4 subgroepen, te weten:

- gespreksvaardigheden gericht op het leggen, onderhouden en afsluiten van een eerste contact met een ander: 4 afzonderlijke vaardigheden.

- gespreksvaardigheden gericht op het actief zichzelf uiten: 9 afzonderlijke vardigheden.

- gespreksvaardigheden gericht op het reageren op anderen: 9 afzonder1 ijke vaardigheden.

- vaardigheden geldend als alternatieven voor agressie: 8 afzonder1ijke vaardigheden.

De persoonlijke basisvaardigheden worden ook wel aangeduid met behulp van de termen "planning skills" en "cognitive skills". Voorbeelden van deze persoonlijke vaardigheden zijn:

- een doel stellen

- plannen maken

- een besluit nemen

- prioriteiten stellen

Bij de persoonlijke basisvaardigheden ligt de nadruk op het aanleren van covert $d . q$. denkgedrag.

Een toepassingsvaardigheid is een samenvoeging van een aantal basisvaardigheden in een zodanige combinatie en volgorde dat het aanpakken van een reëel levensprobleem door middel van deze samengestelde vaardigheid mogelijk wordt. Een voorbeeld van een dergelijke vaardigheid ter illustratie (in letterlijke vertaling):

Vaardigheid 41.:Omgaan met geld

Basisvaardigheden:

1. Een doel stellen

2. Informatie verzamelen

3. Anderen overreden

4. Beslissingen nemen

5. Waardering uitdrukken

Goldstein maakt nergens duidelijk hoe hij tot de keuze en uitwerking van de diverse vaardigheden is gekomen. Hij blijkt het door hem aan- 
geboden pakket nog steeds verder uit te breiden (Goldstein e.a., 1976, $1977,1978,1979,1980,1981)$. Ook wordt door hem geen consequente indeling in skillseries gehanteerd.

Per vaardigheid heeft Goldstein een geluidsband samengesteld, bedoeld om tijdens de groepsbijeenkomsten een voorbeeld - in leertheoretische termen model-functie - te vervullen. Elke band bestaat uft:

- een introductie door een inleider met een hage status. Hij beschrijft de betreffende vaardigheid en onderstreept het belang van de uitvoering daarvan,

- 10 korte "hoorspelen" waarin de leerpunten door verschillende hoofdrolspelers in uiteenlopende situaties worden toegepast,

- een eplloog door eerder genoemde inleider ter afronding.

De vaardigheden worden aangeleerd met behulp van modeling, gedragsoefening, (sociale) bekrachtiging en transfertraining.

Deze basiscomponenten van de methode worden in het nu volgende beschreven.

\subsubsection{Modeling}

De term modeling is afkomstig uit onderzoek met betrekking tot sociale leerprocessen, verricht door Bandura (1969). Deze auteur ontdekte dat model Ing ofwel het demonstreren van gedrag leerprocessen bij de toeschouwers tot gevolg had. Overtuigd van de effectiviteit van de door Bandura ontdekte modelingprocessen, besloot Goldstein (1973) van deze principes gebruik te maken bij de operationalisatie van zijn speciaal op de psychologische kenmerken van clienten uit de lagere sociaaleconomi sche $k l$ assen afgestemde psychotherapte-methode.

Goldstein was van mening dat modeling ofwel model-leren bij uitstek aansloot aan de leerorlëntatie van clienten uit de lagere klassen. In zijn boek uit 1973 doet hij verslag van een aantal experimenten die het optreden van leerprocessen tengevolge van het demonstreren van voorbeelden bevestigen. Goldstein besloot de model-functie te operationaliseren door middel van het laten horen van concrete voorbeelden van de nieuw aan te leren vaardigheden. Deze voorbeelden werden op 
geluidsband opgenomen en met behulp van een cassette-recorder aan de deel nemers gepresenteerd.

Bij de vormgeving van het modelingsprincipe moet, aldus coldstein $(1973)$, rekening gehouden worden met de op emplrisch material gebaseerde bevindingen dat modeling effectlever is wanneer het model c:q. het object wan identificatie:

- meer bedreven of deskundig iljkt,

- een hogere status heeft,

- In meerdere opzichten overeenkamt met degene die het getoonde gedrag wenst aan te leren: hetzelfde geslacht, dezelfde leeftijd etc.,

- vriendelijk en behulpzaam is,

- positieve gevolgen ondervindt van het (doellgedrag.

Deskundigheid en status worden geoperationaliseerd met behulp van de autoriteit die de inleiding verzorgt. De overige voorwarden worden verwerkt in de voringeving van de voorbeelden.

Wat het gedemonstreerde gedrag betreft, geldt dat de tijdens de demonstratie optredende leereffecten optimaal zijn wanmeer het betreffende doelgedrag:

- duidellijk, concreet en gedetailleerd wordt uitgevoerd,

- herhalde malen wordt getoond,

- in de vorm van een hiërarchile van moellijkheidsgraad wordt aangeboden,

- géén dirrelevante nevengedragingen omvat,

- door meerdere personen wordt uittgevoerd.

Voor degene dle het doelgedrag wenst aan te leren, geldt dat het leereffect tijdens de demonstratie het grootst is, wanneer:

- hem van te voren duidelijk wordt gemaakt dat het de bedoellng is dat hilj het doelgedrag gaat imiteren,

- hij dezelfde achtergrond of attitude heeft met betrekking tot de doelvardigheid als het model;

- hij het model vriendelijk gezind is,

- hilj positief bekrachtigd wordt voor het imitteren van het modelgedrag. 


\subsubsection{Gedragsoefening}

A.1s tweede belangrijke leerprincipe, aansluitend aan de leerstiji van clienten uit de lagere sociaal-economische klassen koos Goldstein (1973) het principe van de gedragsoefening. Dit principe impliceert dat de deelnemers aan de vaardigheidstherapieen worden gestimuleerd de nieuw aan te leren doelgedragingen in te oefenen in een therapeutische setting die voldoende velligheid biedt om met eigen gedrag te gaan experimenteren.

Aanvankelijk wordt er gestreefd naar letterlijke imitatie van (delen van) het gedemonstreerde gedrag. Geleidelijk aan worden steeds hogere eisen gesteld aan de client. De oefensituaties worden steeds moeilijker. Men streeft uiteindelijk naar een persoonlijke versie van de betreffende leerpunten. Goldstein is van mening dat leren door gedragsoefening effectiever is:

- naarmate de client het participeren aan de gedragsoefening meer als een eigen keuze ervaart,

- naarmate er sprake is van een grotere mate van "commitment" ten aanzien van het in te oefenen gedrag,

- naarmate de $c l i e n t$ in stat is tot imitatie van het doelgedrag zonder al te veel voorbereidingen en aamwijzingen van de kant van de therapeut(en),

- naarmate het aan te leren gedrag vaker positief bekrachtigd wordt. Gedragsoefening vindt plaats zowel tijdens de groepsbijeenkomsten alsook in de eigen leefsituatie.

\subsubsection{Bekrachtiging}

Positieve sociale bekrachtiging neemt een belangrijke plaats in in het leerproces. Tijdens de groepsbijeenkomsten vindt sociale bekrachtiging plats door therapeut(en) en medegroepsleden. Naast deze sociale bekrachtiging wordt ook uitgebreid aandacht besteed an allerlei vormen van zelfbekrachtiging. Bekrachtiging blijkt het meest effectief wanneer men:

- het soort bekrachtiging dat men hanteert, afstemt op de behoeften en 
wensen van de persoon wiens gedrag(ingen) bekrachtiging behoeft (ven). Hierbij dient bij voorbaat rekening te worden gehouden met het mogelijk optreden van verzadigingseffecten.

- de bekrachtiging onmiddelijk laat wolgen op het optreden van het gewenste gedrag.

- kwantiteit en kwaliteit van de bekrachtiging afstemt op het niveau van de door de clifent geleverde prestatie(s).

- de client in de gelegenheid stelt veelvuldig bekrachtigd te worden,

- in de loop van de behandeling van een continu bekrachtigingsschema averschakelt op een onderbroken bekrachtigingsschema. 0it om te bewerkstelligen dat het gewenste gedrag in het gedragsrepertoire van het betreffende individu aanwezig blijft, ook zonder externe bekrachtiging contingent aan het stellen daarvan.

\subsubsection{Transfertraining}

Het begrip transfertraining verwijst naar de in therapieprogramma's ingebouwde matregelen die erop gericht zijn te bewerkstelligen dat het nieuw aangeleerde doelgedrag ook buften de therapeutische setting en na het verstrijken van de therapieduur wordt toegepast. Het principe van de tramsfertraining heeft dus ook betrekking op de duurzaamheid van het nieuw aan te leren gedrag. Het principe van de transfertraining wordt onder meer geoperationaliseerd in de vorm van huiswerkopdrachten. Teneinde transfer van in therapie aangeleerde gedrag naar de eigen leefsituatie te optimaliseren, dient de therapeut ernaar te streven dat:

- de clienten in therapie gedragsregels aanleren met een brede toepasbaarheid,

- de clienten tijdens de therapiesessies in de gelegenhelld worden gesteld het doelgedrag zo vaak mogelijk te oefenen,

- de oefensituaties tijdens de sessies de nodige overeenkomsten vertonen met de eigen levenssituatie(s),

- het doelgedrag geoefend wordt in een breed scala van uilteenlopende stimulussituaties en met verschillende typen tegenspelers,

- positieve bekrachtiging en correctieve feedback öök in de eigen leefsituatie plaatsvinden. 
De in 1977 in Mastricht geformeerde projectgroep - ook wel Goldsteinprojectgroep genoemd - stelde zich ten doel de door Goldstein ontwikkelde "structured learning therapy" operationeel te maken voor de geestelijke gezondheldszorg in de reglo Zuid-Limburg. Men achtte het noodzakelijk de door Goldstein gepresenteerde methode op een aantal punten te herzien. Besloten werd:

a. een aangepast pakket vaardigheden te definiëren,

b. de geluidsbanden te vervangen door video-programma's,

c. protocollen te ontwikkelen voor de uftvoering van de vaardigheidstherapleën die recht doen aan recente theoretische ontwikkelingen ten aanzien van de verwerving van vaardigheden,

d. onderzoek te doen naar de effecten van de aldus tot stand gekomen vaardigheidstherapleën.

De in Mastricht ontwikkelde Goldsteinversie vormt geen psychotherapeutfsche behandeling "an sich", maar is altijd onderdeel van een meer omvattend(e) behandeling(splan). Er is steeds sprake van een hoofdbehandel aar die een client tijdelijk naar een of meerdere Goldsteintherapleën verwijst. Na afloop van de Goldsteintherapie gaat de client terug naar de hoofdbehandelaar.

\subsubsection{Ontwikkeling van een aangepast pakket vaardigheden}

In 1.4.1. werd de inhoud beschreven van de door Goldstein e.a. ontwikkelde vaardigheidstherapieën. Besloten werd na te gaan op welke wijze het brede scala van interpersoonlijke en persoonlijke vaardigheden, zoals dat door Goldstein werd aangeboden, tot een overzichtelifik en zinvol aantal kon worden teruggebracht.

Wat de keuze van de interpersoonlijke vaardigheidstherapleën betreft, werd het model van Leary (1957) als uitgangspunt gekozen (Beekers en Halfens, 1981; Beekers, 1982).

Op basis van empirisch onderzoek besloot men een serie van 9 interpersoonlijke vaardigheden samen te stellen. Voor een madere beschrij- 
ving van de inhoud van deze serie, zie Beekers (1982).

In navolging van Goldstein werd per vaardigheid een aantal voorgestructureerde leerpunten geformuleerd die de betreffende vaardigheid in zijn afzonderlijke al sook opeenvolgende elementen beschrijven. Deze leerpunten $\mathrm{kwamen}$ tot stand op basis van 1 iteratuurstudie, brainstorming, discussie en rollenspel. Beekers (1982) geeft een overzicht van de leerpunten voor de interpersooml ijke vaardigheden. Wat de persoonlijke vaardigheden betreft, koos men voor de ontwikkeling van een serie van vier vaardigheden. De inhoud van deze vaardigheden werd bepaald op basis van literatuurstudie. Deze literatuurstudie zal in hoofdstuk 2 gerapporteerd worden.

\subsubsection{Productie van videoprogramma's}

op basis van praktische ervaringen en literatuurstudfe werd besloten de geluidsbanden te vervangen door videoprogramma's. Videoprogramma"s blijken een aantal specifieke voordelen te bieden in vergelijking met de door Goldstein ontwikkelde geluidsbanden. Videoprogramma"s vormen een effectievere operationalisatie van de model functie ondat:

- men op video verbale èn non-verbale aspecten van het doelgedrag kan laten zien,

- visuele weergave van het modelgedrag de attentie van de deelnemers bevordert,

- visuele weergave van het modelgedrag meer mogelijkheden biedt tot herkenning van het doelgedrag en identiffcatie met de hoofdrolspe1ers. (Beekers, 1980, 1982 ).

Teneinde de discriminatie van relevante aspecten uit het getoonde modelgedrag te bevorderen, besloot men videomodellen te produceren in de vorm van contrastparen (Beekers, 1980). Dit betekent dat elke voorbeeldscene twee keer achter elkaar aan de clienten wordt aangeboden: eerst zonder dat de leerpunten daarin worden toegepast, vervolgens met toepassing van leerpunten. Praktijkervaringen gaven er bovendien aanleiding toe de belde scenes per contrastpaar door dezelfde hoofdrolspelers te laten vertolken (Beekers, 1982). 
De beschikbare videoprogramma's zlijn gestandaardiseerd van opzet. Een inleider met hoge status introduceert zichzelf en de betreffende vaardigheid. Vervolgens worden drie voorbeeldsituaties aangeboden in de vorn van contrastparen zonder en met leerpunten. Wat deze voorbeeldsituaties betreft, is er steeds sprake van een voorbeeld uit de gezinssfeer, een voorbeeld uit de werksfeer en een voorbeeld uit het openbare leven. Ter afsluiting komt de inleider nogmaals in beeld en onderstreept het belang van het inoefenen van de betreffende vaardigheid: tijdens groepsbijeenkomsten èn in de eigen leefsituatie. Voor elk van de ontwikkelde vaardigheidstherapleën werd een aldus samengesteld videoprogramma geproduceerd. Voor een beschrijving van de videoprogramma's voor de persoonlijke vaardigheden zie 5.2.2.1.

\subsection{3. antwikkeling van therapie-protocollen}

Goldstein (1973) en Goldstein e.a. (1976) geven slechts globale beschrijuingen van de door therapeut(en) tijdens de groepsbijeenkomsten te volgen werkwijze. Dit leidde ertoe dat men besloot voorgestructureerde therapie-protocollen te ontwikkelen ten einde (aspirant) Goldsteintherapeuten meer concrete richtlijnen aan te reiken voor de uitvoering van de vaardigheidstherapieën. Wat de interpersoonlijke vaardigheldstherapieën betreft, hebben deze protocollen inmiddels hun definitieve vom gekregen (Beekers en Gooijen, 1980; Beekers, 1982). Per aan te leren vaardigheid is er sprake van 4 groepsbijeenkomsten verspreid over 4 achtereenvolgende weken. Elke bijeenkomst duurt 2 uur. Per groep nemen 5 à 8 clienten deel. De groep wordt geleid door twee therapeuten.

Het principe van de gedragsoefening werd op eigen wijze uitgewerkt. Het bleek zinvol 3 soorten gedragsoefening - in termen van Beekers (1982) rollenspelen genoemd - van elkaar te onderscheiden, te weten:

- Imiterende gedragsoefening

- anticiperende gedragsoefening

- reconstruerende gedragsoefening.

Elk van deze vormen heeft (een) specifieke doelstelling(en). Deze doelstellingen worden in tabel 1.3. schematisch weergegeven. 


\begin{tabular}{|c|c|}
\hline Soort gedragsoefienling & Doel stoli Ing(en) \\
\hline $\begin{array}{l}\text { - Imiter ende } \\
\text { gedragsoefenlng }\end{array}$ & 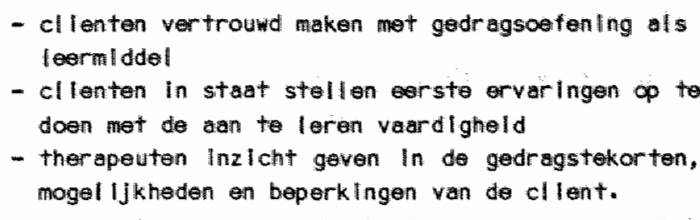 \\
\hline $\begin{array}{l}\text { - Antlciperende } \\
\text { gedragsoefenlng }\end{array}$ & 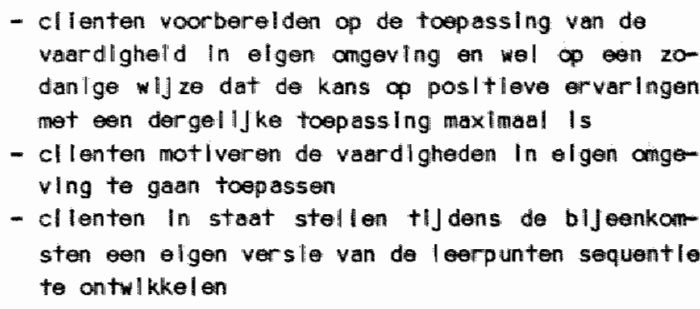 \\
\hline $\begin{array}{l}\text { - Reconstruerende } \\
\text { gedragsoefenling }\end{array}$ & 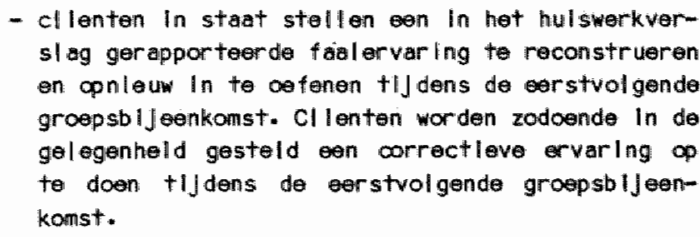 \\
\hline
\end{tabular}

Voor een uitgebreidere beschrijving van de werkwijze bij de interpersoonlijke vaardigheidstherapieën zie Beekers (1982).

In hoofdstuk 3 wordt beschreven op welke wijze het principe van de gedragsoefening wordt geoperationaliseerd bij de uitwoering van de persoonl ijke vaardigheidstherapieën.

In paragraaf 3.7 . worden de therapie-protocollen beschreven zoals die voor de persoonl ijke vaardigheidstherapieën ontwikkeld werden.

Als therapeutische hulpmiddelen bij de uitvoering van persoomlijke en interpersoonlijke vaardigheidstherapieën werden posters ontworpen en huiswerkboekjes samengesteld. Voor elk van de in Maastricht ontwikkelde vaardigheden werd een poster ontworpen met daarop de betreffende leerpuntensequentie in duidelijk leesbare drukletters. Doel van deze posters is de leerpuntensequentie onontkoombaar in de groepszittingen aanwezig te doen zijn. Ook werd voor elke vaardigheld een bijpassend 
huiswerkboekje ontwikkeld. Dit als hulpmiddel voor de deelnemers bij de toepassing van de leerpunten en de uitvoering van de huiswerkopdrachten in de periode tussen de groepsbijeenkomsten.

Voor een beschrijuing van de huiswerkboekjes zoals die bij de persoonilljke vaardigheidstherapleën worden gehanteerd, zie 3.2.4.2.

1.5.4. Bandura's "self-efficacy" theorie als theoretisch verklaringsmodel

Om de tijdens deelname aan vaardigheidstherapleën optredende leerprocessen afdoende te verklaren, werd aansluiting gezocht bij bestaande theoretische verklaringsmodellen. De cognitieve sociale leerthearie van Bandura (1977) bleek een in dit opzicht relevant theoretisch kader te kunnen vormen (zie ook Beekers, 1982). Bandura's "self-efficacy" theorle blijkt implicaties te hebben voor de wijze warop persoonlijke en Interpersoonlijke vaardigheidstherapieën worden uitgevoerd.

In hoofdstuk 5 zullen de implicaties van een driletal cognitief soclaal-1eertheoretische theorieën voor vaardigheidstherapieën uitvoerig worden beschreven.

\subsubsection{Effectiviteit van de Maastrichtse variant}

Besloten werd de door de projectgroep ontwikkelde versie van de vaardighelidstherapieën op effectiviteit te toetsen. Het effect-onderzoek met betrekking tot de interpersoonlijke vaardigheden is immiddels afgerond (Beekers, 1982 ). Uit de resultatem blijkt dat deelname aan deze programma"s ertoe leidt dat:

- clienten de betreffende vaardigheid beter beheersen,

- cllenten ma floop van de therapie melden minder problemen te ervaren met betrekking tot de aangeleerde vaardigheid,

- de zelfwaardering van de clienten toeneemt,

- de algemene klachten warwoor de clienten bij de betreffende instellingen voor geestellijke gezondheidszorg in behandeling kwamen, niet significant meer afnemen dan bij een vergelijkbare controlegroep. 
Deze controlegroep stond op de wachtlijst voor Goldsteintherapie. Tijdens de wachtperiade liepen de individuele contacten van de cl ient met de hoofdbehandel aar gewoon door.

Follow-up onderzoek toonde aan dat de gevonden effecten - vaardigheidsspecifiek en met betrekking tot zelfwaardering - duurzaam waren.

In hoofdstuk 7 wordt een onderzoek beschreven naar de effecten van de persoonlijke vaardigheidstherapieën à la Goldstein.

\subsection{PERSOONLIJKE VAARDIGHEIDSTHERAPIEEN}

In navolging van Goldstein werd door de Maastrichtse projektgroep ook een serie persoonlijke vaardigheldstherapieën ontwikkeld. Tijdens deze vaardigheidstherapieën worden aan de deelnemers daaraan strategieën aangeleerd, gericht op het effectief omgaan met diverse typen van probleemsituaties. De uitwoering van de persoonlijke vaardigheidstherapieën is gebaseerd op dezelfde principes als de uftroering van de interpersoonlijke vaardigheidstherapieèn. In de praktijk bleek echter al spoedig dat het noodzakelijk was de werkwijze zoals die bij de uitvoering van de interpersoonlijke vaardigheldstherapieën werd toegepast, in een aantal opzichten te herzien. Bij het inoefenen van persoonlijke vaardigheden speelt het aanleren van denkstappen, c.q. cognitieve gedragselementen een grotere rol dan bij het inoefenen van interpersoonlijke vaardigheden. Bij de interpersoonlijke vaardigheden ligt de nadruk op het aanleren van overt gedrag, bij de persoonlijke vaardigheden op het aanjeren van covert gedrag. Het inoefenen van persoonlijke vaardigheden bleek daardoor andere eisen te stellen aan client, therapeut en vormgeving van met name modeling al sook gedragsoefening dan het inoefenen van interpersoonlijke vaardigheden. In de nu volgende hoofdstukken zal de ontwikkeling en evaluatie van de persoonl ijke vaardigheidstherapieën à la Goldstein worden beschreven. 
HOOFDSTUK 2. BESCHRIJVING VAN DE WIJZE WAAROP DE INHOUD VAN DE PERSOONLIJKE VAARDIGHEIDSTHERAPIEEN WERD BEPAALD

\subsection{INLEIDING}

In dit hoofdstuk wordt aandacht besteed aan de wijze waarop de inhoud van de persoonlijke vaardigheidstherapieën werd vastgesteld. Het werk van Arnold Goldstein diende daarbij als uitgangspunt, aangevuld met bevindingen uit literatuluronderzoek. In het nu volgende zullen zowel Goldstein"s ontwerp als de daarop in Maastricht ontwikkelde variant aan de orde komen. De bedoelde variant omvat een serie van vier persoonlijke vaardigheden, te weten "dagelijkse problemen aanpakken", "veranderingen aanpakken", "beslissingen nemen" en "informatie verzamelen"'. Deze vaardigheden worden in het nu volgende elk afzonderlijk beschreven.

\subsection{GOLDSTEIN'S ONTWERP}

Zoals reeds eerder vermeld werd, onderscheiden Goldstein e.a. (1976, $1977,1978,1979,1980,1981$ ) in het door hen ontworpen pakket basisvaardigheden een serie skills die zij nu eens aanduiden als "personal skills", dan weer als "self-control-ski11s".

De door hen in 1976 im dit opzicht beschreven serie bestaat uit de volgende vaardigheden:

- setting a goal

- gathering information

- concentrating on a task

- evaluating your abilities

- preparing for a stressful conversation

- setting problem priarities

- decision making. 
Deze vaardigheden (ski11s) hebben betrekking op de wijze waarop het individu zijn persoonlijk leven structureert: de wijze waarop men doelen stelt, informatie verzamelt, beslissingen neemt en actief probleemoplossend te werk gaat. Door toepassing van deze vaardigheden is het individu in staat adequat het hoofd te bieden aan problematische situaties uit het dagelijks leven. Ter onderscheiding van de interpersoonlijke vaardigheden noemt Goldstein deze vaardigheden persoonlijke vaardigheden. Naar zijn mening heeft psychologische vaardigheidstraining in vele gevallen de voorkeur boven psychotheraple, waarbij hij waardigheidstraining omschrijft als "the planned, systematic training of the specific behaviors needed and consciously desired by the individual in order to function in an effective and satisfying manner over an extended period of time, in a broad array of positive, negative and neutral personal and interpersonal contexts" (Goldstein, 1981, p.6).

Interpersoonlijke vaardigheden verwijzen naar de competenties van het individu zoals die een rol spelen in interacties met anderen.

Persoonlijke vaardigheden omschrijft Goldstein als de "emotional, cognitive, observational skills that relate to practical aspects of daily living in work, school or home environments. They include selfcontrol, decision making, goal setting, preparing for a stressful conversation and setting problem priarities" (Goldstein, 1981, p.8). $B i j$ het intrainen van persoonlijke vaardigheden maakt de therapeut conform de werkwijze bij de interpersoonlijke vaardigheidstherapieên gebruik van voorgestructureerde leerpunten en een geluidsband met daarop een autoriteit die de vaardigheid inleidt en een aantal voorbeelden, warin de betreffende leerpunten zijn verwerkt.

Goldstein is van mening dat de persoonlijke vaardigheden op dezelfde wijze aan clienten kunnen worden aangeleerd als interpersoonlijke vaardigheden. Hij acht het niet noodzakelijk de basisprincipes van de door hem ontworpen leermethode aan te passen aan de typische eigen aard van de persoonlijke vaardigheidstherapieën. Bij het aanleren van persoonlijke vaardigheden wordt dan ook gebruik gemaakt van dezelfde leerprincipes $\mathrm{nl}$. modeling, gedragsoefening, (sociale) bekrachtiging en transfertraining als bij het aanleren van interpersoonlijke vaardigheden. 
In 2.3.1. $t / m$ 2.3.4, wordt de inhoud van de serje persoonlijke vaardigheden beschreven aan de hand van een literatuurstudie, waarbij de begrippen "cognitive skills", "personai ski1ls", "problem-solving sk111:s" als trefwoorden fungeerden.

Aans1uitend aan de 1 iteratuurgegevens en het in 2.2. beschreven ontwikkel ingswerk van Goldstein C.S., besloot men de volgende vier vaardigheden te kiezen: "dagelijkse problemen aanpakken", "beslissingen nemen", "informatie verzamelen" en "veranderingen aampakken". Deze vaardigheden werden aanvankelijk aangeduid als "vaardigheden voor doelmatig handelen" en als "cognitieve vaardigheden". Bij nader inzien bleken beide benamingen zwaarwegende nadelen te hebben. De benaming "vaardigheden voor doelmatig handelen" heeft als nadeel dat hij eenzijdig verwijst naar een louter rationalistïsche aanpak waarin geen enkele aandacht wordt besteed aan emotionele aspecten.

De benaming cognitieve vaardighedien heeft als nadeel dat de indruk wordt gewekt dat alleen cognitieve gedragsaspecten worden aangeleerd terwijl in feite sprake is van het aanleren van een combinatie van overte en coverte ( $=$ cognities) aspecten van gedrag. Op basis van bovenstaande overwegingen besloot men de term "persoonlijke" vaardigheden te verkiezen boven "vaardigheden voor doelmatig handelen" en ook boven "cognitieve" vaardigheden.

\subsection{1. "Dagelijkse prob1emen aanpakken"}

De vaardigheid "dagellijkse problemen aanpakken" werd ontwikkeld aan de hand van de bestaande probleemoplos-1iteratuur. De term probleemoplossen wordt in de psychologie veelvuldig gehanteerd. In zijn algemeenheid kan men stellen dat de term verwijst naar een complex cognitief proces dat in verschillende typen probleemsituaties van toepassing is. De experimentele psychologie houdt zich reeds sinds Thorndike (1898) bezig met de bestudering van dit proces. Het probleemoplos-proces werd jarenlang alleen experimenteel onderzocht in het psychologisch laboratorium en aan de hand van puzzels, anagrammen en inzichtsproblemen 
(Underwood en Schultz, 1960; Mayzner en Tresselt, 1958; 0 "Connell en Duncan, 1961 ).

Rond $1960 \mathrm{kan}$ men de eerste pogingen onderscheiden, de tot dan toe ontwikkelde inzichten uit de probleemoplos-1iteratuur van toepassing te doen zijn op zgn. sociale problemen. In deze periode kwamem de eerste trainingen in probleemoplossen tot ontwikkeling. Zo ontwierpen osborn (1963) en Suchman e.a. (zie Davis, 1973) als eersten trainingsprogramma's in probleemoplossen voor managers $c . q$. studenten. Tien jaar later werden de eerste pogingen gedaan de kennis opgeslagen in de probleemoplos-literatuur van nut te doen $z i j n$ voor de $k l i n i s c h e$ zowel als ambulante geestelijke gezondheidszorg (D'Zurilla en Goldfried, 1971). Alvorens nader op deze toepassingsvorm in te gaan, wordt allereerst aandacht besteed aan een korte verkenning van de probleemoplosliteratuur.

Conform Davis (1973) kan men in de psychologische literatuur met betrekking tot probleemoplossen twee stromingen onderscheiden.

Enerzijds een groep van fundamentele onderzoekers die de basisfuncties c.q. basisprocessen bestuderen, die bij probleemoplossen een rol spe1 en.

Anderzijds een groep toepassingsdeskundigen, werkzaam in de industriële en educatieve sector, die de probleemoplos-vaardigheden, zoals die in het dagelijks leven van het individu van belang zijn, proberen op te sporen en te operationaliseren ten behoeve van trainingsprogramma's.

Feldhusen en Guthrie (1979) onderscheiden 3 soorten benaderingen wat de bestudering van het probleemoplos-proces betreft, te weten:

a. de probieemoplos-modellen gebaseerd op computersimulaties,

b. de zgn. "mensel ijke vermogens" opvattingen,

c. de zgn. "creatieve" probleemoplos-modellen.

In het nu volgende zal elk van deze benaderingen nader worden toegelicht.

a. Miller, Gallanter en Pribam (1960); Newell en Simon (1972); Gagnë (1977); Scandura (1977) zijn van mening dat men computerprogramma's kan ontwikkelen die het verloop van complexe menselijke probleemoplos-pracessen simuiteren. Bij deze benadering wordt probleemoplossen 
opgevat als een combinatie van een aantal cognitieve basisfuncties die volgens vastgestelde regels met elkaar interacteren.

De mogelijkheid tot het opslaan van informatie in het geheugen en het na verloop van tijd opnieuw kunnen oproepen van de opgeslagen informatie vormen in dit opzicht essentiële vaomaarden. Waarnemings- en beoordelingsprocessen worden als sturende mechanil smen opgevat bij het probleemoplos-proces dat volgens vaste, hièrarchisch gestructureerde regels 11 jkt te verlopen.

Uitgaande van een dergelijk model veronderstelden Feldhusen $e_{*} a$. (1972) dat bij probleemoplossen een twalftal factoren een rol spe1en. Op basis van deze factoren ontwierpen zij een problem-solwing test voor kinderen. Factor-analytisch onderzoek van Speedie e.a. (1973) vond bevestiging voor 6 van deze factoren $n 1$. :

- verificatie

- het opmerken van relevante detalls

- het herkenmen van het probleem

- het definiëren van het probleem

- het kunnen zien van mogelijke impilicaties

- bekende voorwerpen op ongebruikelijke wijzen kunnen warnemen.

b. Ultgaande van de corspronkelijk uit de wijsgerige antropologie in de psychologie overgenomen vermogensleer, stelt Guilford (1967) complexe typisch menselijke vermogens centraal in het probleemoplos-proces. 0ok Gullford streeft ernaar meer inzicht te krijgen in aard en aantal van de mentale operaties die in dit opzicht een rol spelen. Geheugen, opname van informatie, cognitie, productie en evaluatie worden door hem als typisch menselijke basisfuncties opgevat. (Zle ook Schuerman, 1977).

Guilford en Hoepfner (1971) vonden in door hen werricht onderzoek bevestiging voor de rol van de nu volgende mentale operaties:

- het vermogen objecten/ideeën te classificeren;

- het vermogen verschillende relaties te ontdekken tussen de diverse eigenschappen wan een object of situatie;

- het vermogien een reeks kenmerken te onderkennen met betrekking tot het doel dat men nastreeft;

- het vermogen de antecedenten van een situatie te kunnen analyseren conform de wetten van de logica. 
Het onderzoek leverde geen empirische bevestiging op voor de rol van:

- het vermogen snel een aantal kenmerken van een voorwerp te kunnen bedenken;

- het vermogen alternatieven te genereren;

- een algemene probleemoplos-factor.

c. De model-ontwikkeling met betrekking tot creatief probleemoplossen ontstond op basis van uitgebreide research met betrekking tot creativiteit en divergent denken (Guilford, 1967). De term divergent denken verwijst naar de denkprocessen die resulteren in "nleuwe" oplossingen. Zoals de fundamentele research de factoren analyseert die in het probleemoplos-proces een rol spelen, zo neemt de toegepaste research de stadia en daarbij behorende vaardigheden onder de loupe zoals die in het creatieve probleemoplos-proces een rol spelen. Deze stadia worden veelal aangeduid als de lineatre stappen uit een strategie. Het werk van 0sborn (1963) vormt een van de belangrijkste ontwikkelingen op dit gebied. Hij ontwierp een aantal zeer bekend geworden brainstormingstechnieken. Deze auteur onderscheidt de volgende 10 stappen in het creatieve probleemoplosproces:

1. inventariseer alle aspecten aan het probleem;

2. kies een subprobleem om aan te gaan werken;

3. bepaal welke gegevens van pas komen;

4. kies manieren om deze gegevens te verzamelen;

5. bedenk alle mogelijke oplossingen;

6. selecteer de meest belovende oplossingen uft;

7. bepaal op welke manieren je de oplossingen kunt uittesten;

8. zoek de beste uit;

9. bedenk alle mogelijke gevolgen;

10.kies de beste oplossing.

Torrance en Meyers (1970) op hun beurt delen dit proces op in 6 lineaire stappen:

1. de voorwaarden creëren die probleemoplossen mogelijk maken;

2. problemen en uitdagingen zien/waarnemen; 
3. het werkelijke probleem herkennen;

4. alternatieven/oplossingen bedenken;

5. ideeën evalueren;

6. de implementatile van deze ideeën voorbereiden.

Parnes, Noller en Biondi (1977) leren creatief probleemoplossen aan met behuip van 5 stappen $\mathrm{ni}$ :

1. onderzoek naar feiten;

2. beslult het probleem op te lossen;

3. ideeën verzamelen;

4. oplossingen bedenken;

5. uitvoering/implementatie.

Uit de hierboven besproken modellen blijkt dat er geen overeenstemming bestaat over aantal, aard en inhoud van de stadia c.q. stappen die men in het creatieve probleemoplos-proces kan onderscheiden. Waar 0sborn 10 stadia onderscheidt, onderscheiden Torrance en Meyers er 6 en Parnes e.a. 5. Wat de inhoud van de stadia betreft, blijkt dat:

- in alle drie de modellen het verzamelen c.q. bedenken van oplossingen een rol speelt.

- onderzoek naar feiten in twee van de drie modellen een rol speelt (Osborn, 1963; Parnes e.a., 1977).

- herkenning c.q. omschrijuing van het probleem in twee van de drie modellen als apart stadium voorkomt (Osborn, 1963; Torrance en Meyers, 1970).

- uitvoering/implementatie in twee van de drie modellen als aparte fase wordt onderscheiden (Torrance en Meyers, 1970; Parnes e.a., 1977).

- Torrance en Meyers (1970) expliciet aandacht besteden aan het creëren van een adequate probleemoplos-set c.q. -attitude.

- Parnes e.a. (1977) expliciet andacht besteden aan de beslissing het probleern al dan niet te gaan oplossen.

- het model van Osborn (1963) het stellen van subdoelen en het uittesten van oplossingen als aparte stadia benoemt. 
Bovenstande leidt tot de conclusie dat de auteurs die creatieve probleemopios-modellen ontwikkelen, leder hun elgen keuze doen wit aard en aantal van de diverse stadia betreft. Er is sprake van een groot aantal verschillende varianten op hetzelfde thema. over het algemeen genomen kan men stellen dat deze varianten globaliter allen dezelfde lijn vertomen maar daarbij verschillende aspecten uit het totale probleemoplos-proces benadrukken c.q. meer in detail uitwerken. In de beschikbare literatuur zijn geen aanwijzingen beschikbaar die de superioritelt van éen wan deze modellen bevestigen. Voor elk wan de door de diverse auteurs onderschelden stadia kan men in de probleemopios-literatuur ondersteunend feitenmateriaal ontdekken. De beschikbare gegevens bieden geen houvast in de richting van éën uniform model. Het felt dat er met zoveel verschillende modellen wordt gewerkt, heeft tot gevolg dat onderzoeksgegevens onderling niet vergelijkbaar zijn en daardoor slechts van beperkte waarde c.q. beperkt generaliseerbaar.

Bovenstaande leidt tot de conclusie dat computer-simulaties (a) en vemogens-modellen (b) erop gericht zijn meer inzicht te verwerven in de wijze waarop het probleemoplos-proces verloopt. Beide soorten modellen streven ernaar de psychologische functiles c.q. eigenschappen op te sporen die bij: complex menselijk probleemoplossen een rol spelen. De computer-simulaties richten zich op algemeen functie-onderzoek terwijl de vermogens-modellen onderzoek doen naar specifieke eigenschappen bij welomschreven groepen. De creatieve probleemoplos-modellen (c) daarenteglen stellen zich ten doel trainingsprogramma's in probleemoplossen te ontwikkelen voor specifieke doelgroepen.

Uitgaande van de vooronderstelling dat veel vormen van abnormaal gedrag en de daarmee samenhangende emotionele stoornissen kunnen worden opgevat in termen van ineffectief gedrag en de gevolgen daarvan, stelden D'Zurl11a en Goldfried (1971) als eersten voor probleemoplossen een eigen plaats te geven in het veld van de gedragsmodifficatie. De auteurs verkiezen de term problematische situatie boven de term probleem vanwege het feit dat de sociale contekst vrijwel altijd een cruciale rol speelt. onder een problematische situatie verstaan $D^{\prime} Z u_{-}$ 
rilla en Goldfried (1971, p.107):

"A specific situation or set of situations to which a person must respond in order to function effectively in his environment. To point up this situational emphasis the term problematic situation w111 be used in most instances instead of problem. In the present context a situation is considered problematic if no effective alternative is immediately available to the individual confronted with the situation".

Een effectieve respons kan daarbij worden opgevat als een respons of patroon van responsen die de situatie zo veranderen dat deze niet langer problematisch is, dat wil zeggen voor het individu een maximum aan positieve en een minimum aan negatieve gevolgen met zich meebrengt. Probleemoplossen wordt door hen omschreven als een "behavioral process wether covert or cognitive in nature which:

a. makes avallable a variety of potentially effective response alternatives for dealing with the problematic situation.

b. increases the probability of selecting the most effective response from among these various alternatives."

Probleemoplossen betekent zo gezien niet hetzelfde a1s het stellen van een effectieve respons in een bepaalde probleemsituatie, maar duidt op het proces waarlangs men een oplossing voor het betreffende probleem tracht te vinden. Het stellen van een effectieve response vooronderstelt motivatie en beschikbaarheid van adequate uitvoeringsvaardigheden. D"Zurilla en Goldfried (1971) veronderstellen dat:

a. ineffectiviteit in het omgaan met problematische situaties gevolgen heeft op persoonlijk en sociaal vlak die kunnen leiden tot stoornissen in emoties c.q. gedrag(ingen), die psychologische behande1 ing behoeven.

b. training in algemene vaardigheden, die het individu in staat stellen "to deal independently with the challenge of day to day 1 iving" een uitbrelding $c . q$. versterking van het algehele copingrepertoire van het betreffende individu bewerkstelligt en een preventief effect heeft.

Spivack, Platt en Shure (1976) en Mahoney en Arnkoff (1978) komen bij hun inventarisaties van onderzoeksbevindingen met betrekking tot de 
relatie tussen probleemoplossen en geestellijke gezondheid tot de conclusies dat:

- mensen met zogenaamd "normaal" gedrag anders omgaan met problemen dan subpopulaties met "abnomaal" gedrag (verslaafden, psychiatrische patienten etc.). Emotioneel gestoorden bijken minder oplossingen te kunnen bedenken voor aan hen aangeboden standaardprobleemsituaties, terwijl de door hen wel bedachte oplossingen vaak antisociaal van aard zijn. Bovendien blijkt deze groep nauwelijks enig idee te hebben van de mogelijke gevolgen van de door hen zelf bedachte oplossingen.

- "personal problem solving" aan individuen kan worden aangeleerd met als gevolg dat hun emotionele problemen verminderen.

Bovenstaande gegevens leidden ertoe dat men steeds meer pogingen ging doen trainingsprogramma's in probleemoplossen te ontwikkelen voor de geestelijke gezondheidszorg. Velen hanteerden daarbij het door D"Zurilla en Goldfried (1971) beschreven probleemoplos-model als uitgangspunt. Bestudering van de ult tgebreide en nogal veelomvattende probleemoplos-1iteraturur had tot gevolg dat laatstgenoemde auteurs vijf fasen in het probleemoplos-proces wensten te onderscheiden: een algemene probleemariëntatie-fase, een probleemdefinitie-fase, het genereren van altermatieven, een besluitwormingsfase en een verificatie-fase. Tijdens de training worden deze stappen aan het individu aangeleerd: elk afzonderlijk èn als organisch geheel. De auteurs die in navolging van D'Zurilla en Goldfried soortgelijke programma"s ontwikkelden, presenteren allen een eigen variant op de door deze auteurs uitgewerkte fasering. Tabel 2.1. geeft een overzicht van de overeenkomsten en verschillen tussen de diverse auteurs onderling, waarbij het model van D'Zurilla en Goldfried als referentle-punt dient. 
Tabel 2.1. Overzleht wan wersehlll lande problemioplos-modellen

\begin{tabular}{|c|c|c|c|c|c|c|}
\hline $\begin{array}{l}\text { proces } \\
\text { itosent } \\
\text { Auteurs }\end{array}$ & $\begin{array}{l}\text { lgeneno } \\
\text { orlentio- } \\
\text { ll }\end{array}$ & $\begin{array}{l}\text { probleen } \\
\text { definl illo } \\
\text { on formut } \\
\text { lerling }\end{array}$ & $\begin{array}{l}\text { gemereren } \\
\text { wan an- } \\
\text { yerno- } \\
\text { tlevent }\end{array}$ & $\begin{array}{l}\text { besluit- } \\
\text { worming: } \\
\text { byalua } \\
\text { the en } \\
\text { selectlo }\end{array}$ & $\begin{array}{l}\text { werlicar } \\
\text { the }\end{array}$ & $\begin{array}{l}\text { stadia nlet be- } \\
\text { noend Im thet } \\
\text { coor o"Zur } 111 \mathrm{a} \\
\text { en coldtrled } \\
\text { ultgewerkte mo- } \\
\text { dal }\end{array}$ \\
\hline Helims, 1970 & - & + & $=$ & - & + & $\begin{array}{l}\text { - Informetle } \\
\text { verzamelen la } \\
\text { elgen krling } \\
\text { - objectlef on- } \\
\text { derzook }\end{array}$ \\
\hline $\begin{array}{l}\text { Allan, Chlns- } \\
\text { ky, Larcan, } \\
\text { Lochnen en } \\
\text { Sel Inger, } \\
1976\end{array}$ & - & 4 & + & & - & geen \\
\hline $\begin{array}{l}\text { Arnkoff on } \\
\text { stemart, } 1975\end{array}$ & + & * & + & + & - & geen \\
\hline $\begin{array}{l}\text { Badell., Ar- } \\
\text { cher on Mar- } \\
\text { lowe Jir., } 1980\end{array}$ & (- & $\#$ & + & + & - & $g e n$ \\
\hline $\begin{array}{l}\text { Br Ight Ro- } \\
\text { bIn, } 1981\end{array}$ & - & + & + & + & - & $\begin{array}{l}\text {-het tot lin do } \\
\text { talls plannen } \\
\text { van de gekozen } \\
\text { oplosilng }\end{array}$ \\
\hline $\begin{array}{l}\text { Coché en } \\
\text { Filck, 1975: } \\
\text { Coché en } \\
\text { Douglas, } 1977\end{array}$ & - & + & + & - & - & geen \\
\hline $\begin{array}{l}\text { Crolghead, } \\
\text { Kazdin an Mar } \\
\text { honey, } 1976\end{array}$ & * & \# & $\because$ & $\therefore$ & + & geen \\
\hline $\begin{array}{l}\text { Edelstaln, } \\
\text { Couturo, Cray, } \\
\text { Dickensi } \\
\text { br Luse- } \\
\text { brink, } 1980\end{array}$ & - & + & + & 4 & - & $\begin{array}{l}\text { - de gekozen op- } \\
\text { losslng in } \\
\text { prak+lJk bram- } \\
\text { gen }\end{array}$ \\
\hline $\begin{array}{l}\text { Gor shaw on } \\
\mathrm{B} \| \text { I }^{*}, 1977\end{array}$ & + & + & * & + & + & geon \\
\hline Glllosplo, 1977 & + & + & $*$ & + & * & $g e e n$ \\
\hline
\end{tabular}




\begin{tabular}{|c|c|c|c|c|c|c|}
\hline $\begin{array}{l}\text { Coldo lad an } \\
\text { Davisom, } 976\end{array}$ & + & + & + & + & + & gen \\
\hline Goldfrled, $\quad 980$ & $*$ & + & + & + & + & gevin \\
\hline Hepp ner 1978 & + & + & + & + & t & $\operatorname{gan}$ \\
\hline Hal I andor, 1980 & + & + & + & + & + & 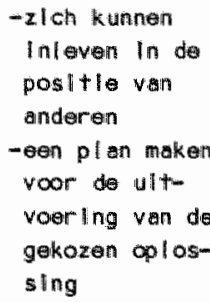 \\
\hline $\begin{array}{l}\text { Houtz an Fold- } \\
\text { husen, } 1976\end{array}$ & - & + & + & + & H & 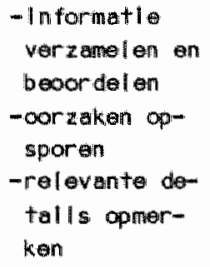 \\
\hline $\begin{array}{l}\text { Intag | I ata, } \\
1978\end{array}$ & + & + & + & + & - & ge⿻n \\
\hline Jacobson, 1977 & - & t. & + & + & - & gean \\
\hline $\begin{array}{l}\text { Jacabson em } \\
\text { Anderson, } 1980\end{array}$ & - & + & + & + & - & 900 \\
\hline $\begin{array}{l}\text { Kendall en } \\
\text { Hol loni. } 1979\end{array}$ & + & 4 & + & + & + & gom \\
\hline Hor $1 \mathrm{sin}, 1974$ & - & + & + & + & - & 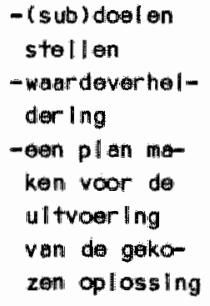 \\
\hline Magoon, 1969 & - & + & - & + & + & $\begin{array}{l}\text { - ln formetlo } \\
\text { verzamellen en } \\
\text { beoordolen } \\
\text { - do gakozen } \\
\text { oplossing } \\
\text { ul troerer }\end{array}$ \\
\hline
\end{tabular}




\begin{tabular}{|c|c|c|c|c|c|c|}
\hline $\begin{array}{l}\text { Mayo on Nor- } \\
\text { ton, } 1980\end{array}$ & - & 4 & + & * & - & guen \\
\hline $\begin{array}{l}\text { Molchentoum, } \\
\text { 1977 }\end{array}$ & - & 4 & + & + & + & $\begin{array}{l}\text { - de gekozen op- } \\
\text { loss Ing in } \\
\text { praktlJk bran- } \\
\text { gen }\end{array}$ \\
\hline $\begin{array}{l}\text { McGutre en } \\
\text { s1fneos, } 1970\end{array}$ & - & * & + & + & - & $\begin{array}{l}\text {-reall tells- } \\
\text { toets lng } \\
\text { - nagaan welke } \\
\text { omgewlingscon- } \\
\text { ditles van In- } \\
\text { vloed zijn } \\
\text { - de reactles } \\
\text { van de persoon } \\
\text { op succes en } \\
\text { falen vast- } \\
\text { stellen }\end{array}$ \\
\hline $\begin{array}{l}\text { Mendonca on } \\
\text { siless, } 1976\end{array}$ & + & + & + & + & * & gen \\
\hline Meyers, 1978 & - & + & 4 & + & - & $\begin{array}{l}\text { - ultwoer ing van } \\
\text { de gekozen op- } \\
\text { losiling }\end{array}$ \\
\hline $\begin{array}{l}\text { Patter son, hops } \\
\text { on Walss, } 1975\end{array}$ & - & $\#$ & + & + & - & -onder handet en \\
\hline $\begin{array}{l}\text { Poltras-Martlin } \\
\text { en Stone, } 1977\end{array}$ & - & + & + & + & - & geen \\
\hline $\begin{array}{l}\text { Ven Quekel- } \\
\text { ber ghe, } 1979\end{array}$ & + & + & + & + & - & $\begin{array}{l}\text { - het maken van } \\
\text { oen sltuatle- } \\
\text { en doel analyse } \\
\text {-plannling en } \\
\text { ultwoer ing van } \\
\text { de gekozen op- } \\
\text { lossing }\end{array}$ \\
\hline $\begin{array}{l}\text { Rlichards on } \\
\text { Perr 1. } 1978\end{array}$ & $*$ & + & + & + & + & geen \\
\hline $\begin{array}{l}\text { Robln, Kent, } \\
\text { o'Leary, Fos } \\
\text { ter en PrInz, } \\
1977\end{array}$ & - & + & + & + & - & $\begin{array}{l}\text {-pllaming wan } \\
\text { de ultroer lng } \\
\text { van de gekozen } \\
\text { oplossing }\end{array}$ \\
\hline $\begin{array}{l}\text { Slegel en } 5 p \mid- \\
\text { veck, } 1976\end{array}$ & - & * & + & + & - & geen \\
\hline
\end{tabular}




\begin{tabular}{|c|c|c|c|c|c|c|}
\hline $\begin{array}{l}\text { Sp Ivack on } \\
\text { Shure, } 1974\end{array}$ & - & + & + & + & $=$ & $\begin{array}{l}\text { - de gekozen op- } \\
\text { losslng ln } \\
\text { praktllk brem- } \\
\text { gen }\end{array}$ \\
\hline \multirow[t]{2}{*}{$\begin{array}{l}\text { Splvack, Platt } \\
\text { en Shure, } 1976\end{array}$} & \multirow[t]{2}{*}{+} & \multirow[t]{2}{*}{-} & \multirow[t]{2}{*}{+} & \multirow[t]{2}{*}{+} & \multirow[t]{2}{*}{ - } & $\begin{array}{l}\text {-de middelen } \\
\text { vaststellen } \\
\text { dle nodlg IIJn } \\
\text { or on bepari- } \\
\text { do oplassling } \\
\text { In praktlJk to } \\
\text { brengen }\end{array}$ \\
\hline & & & & & & $\begin{array}{l}-00 \mathrm{~g} \text { hebben } \\
\text { voor belnwloe- } \\
\text { dling door an- } \\
\text { derim }\end{array}$ \\
\hline $\begin{array}{l}\text { Stono, HInds an } \\
\text { Schmidt, } 1975\end{array}$ & - & + & + & + & - & goen \\
\hline $\begin{array}{l}\text { Urbain en Ken- } \\
\text { dall }, 1980\end{array}$ & + & + & + & $*$ & + & geen \\
\hline
\end{tabular}

+ WEL AAWWEZIG

- NIET AANWEZ\|G

Uit tabel 2.1. blijkt dat:

- 16 van de 37 geciteerde studies een algemene orientatiefase onderscheiden.

- 36 van de 37 geciteerde studies een probleemdefinitie fase onderscheiden.

- 35 van de 37 geciteerde studies het genereren van al ternatieven als een aparte fase onderscheiden.

- 35 van de 37 geciteerde studies een besluitvormingsfase onderscheiden.

- 15 van de 37 geciteerde studies een verificatiefase onderscheiden.

- de categorie toegevoegde fasen een verzameling van tamelijk uiteenlopende fasen vormt waarbij informatie-verzameling en planning en uftwoering van de gekozen oplossing het meest frequent voorkomen.

- dat dit soort trainingsprogramma's wordt toegepast in geestelijke gezondheidszorg en onderwijs; voor preventieve en therapeutische doeleinden. 
Op basis van bovenstaande gegevens besloot de Maastrichtse Goldsteinprojectgroep een probleem-oplos-vaardigheid in de serie persoonlijke vaardigheidstherapleën op te nemen. Gekozen werd voor een vaardigheid probleem-oplossen warin in ieder geval een probleemdefinitiefase, het genereren van alternatieven en een beslultwormingsfase waren opgenomen. Een en ander conform de eerder aangehaalde 1 iteratuur. De ontwikkelde probleem-oplos-vaardigheid kreeg als titel "dagelijkse problemen aanpakken" en werd geoperationaliseerd met behulp van de nu volgende leerpunten:

1. ga na wat precies het probleem is.

2. bedenk een aantal oplossingen.

3. zet de voor- en nadelen van elke oplossing op een rij.

4. kies de oplossing die je het beste past.

5. breng die oplossing in praktijk.

Toelichting: leerpunt 1 vormt de operationalisatie van de probleemdefinitiefase; leerpunt 2 van het genereren van alternatieven en leerpunt 3 en 4 operationaliseren tesamen de besluitvormingsfase. Aanleiding tat deze opsplitsing vormde de door Spivack Platt en Shure (1976) gerapporteerde bevinding dat het vooruit kunnen bedenken van gevolgen een vaardigheid op zich vormt die bij veel mensen met emotionele problemen ontbreekt. De toetsingsfase - ook wel verificatiefase genoemd werd vervangen door een uitvoeringsfase vanwege het idee dat een uitvoeringsfase een noodzakelijk onderdeel dient te vormen van een training c.q. therapie in probleemoplossen in leertheoretisch kader. Wat de titel van de vaardigheid betreft, koos de projectgroep voor "dage1 ijkse problemen aanpakken", enerzijds on aan te geven dat het gaat om problemen in situationele context, anderzijds appelleert deze betite1 ing op toepassing van de aan te leren strategie op alledaagse (=minor) problemen. "Aanpakken" benadrukt dat men de deelnemers aan deze vaardigheidstherapie een strategie voor het actief vinden van oplossingen wenst aan te leren en dat $z i j$ miet een passief aanbod van concrete oplossingen dienen te verwachten.

De probleenorientatle-fase is niet in de leerpunten sequentie opgenomen, maar komt wel uitgebreid aan de orde tijdens de groepsbijeenkomsten. Deze fase betreft de attitude van het individu ten opzichte van 
het hebben van problemen. Het bleek niet mogelijk deze attitude-aspecten in de vorm van ëén enkel leerpunt weer te geven. Deze attitude of set is impliciet in de ontworpen wardigheidstheraple aanwezlg.

Trainingen in probleemoplossen blijken door de eerder beschreven auteurs (zie tabel 2.1.) bij zeer witeenlopende populaties te worden toegepast. Tabel 2.2. geeft een owerzicht van deze populaties.

Tabell 2.2. Owerzlcht doelgroepen problemoplos-ther ap leen

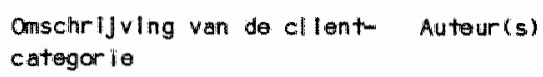

- adollescenten

Coché en FIIckk (1975); Coché en Douglas (1977); Goldfirlad en Dawison (1976); Melchenbaum (1977): Spllwack, Platt on Shure (1976).

\begin{tabular}{|c|c|}
\hline - alcohol ver sl ala fdan & Intagl lata (1978); Goldfrled (1980). \\
\hline - dellinquenten & kendall on Hollon (1979). \\
\hline - (echt)p aren & $\begin{array}{l}\text { Patterson: hops an Welss (1975); Jacobson }(1977 \text { : } \\
1979) \text {; Jiacobson an Anderson }(1980) \text {. }\end{array}$ \\
\hline
\end{tabular}

- ex-gevangemer Goldfr led an Dawison (1976)

- ex-psychiatrlsche patienten Gershaw en Blllar (1977); Goldfrled en bavlson $(1976)$.

\begin{tabular}{|c|c|}
\hline - ex-versl aafden & $\begin{array}{l}\text { Goldfrled on Davison }(1976) ; \text { Goldfrled }(1980) \text {; } \\
\text { Molchenbaun (1977). }\end{array}$ \\
\hline - gezlanen & $\begin{array}{l}\text { Brilght en Robln (1981); Goldfrled (1980); RobIn; } \\
\text { Kent on O"Leary (1977). }\end{array}$ \\
\hline - kInderen & $\begin{array}{l}\text { Goldfr lead en Devlson }(1976) \text {; Houtz en Feldhusen } \\
\text { (1976); Meyers (1978); Poltras-Martin on Stone } \\
(1977) \text {; Splvack on Shure (1974); Stome, Hlinds en } \\
\text { Schmldt (1975); Urbaln gn Kendall (1980). }\end{array}$ \\
\hline
\end{tabular}

- menisen ult de lagere socl- Adkins (1970) y Allen, ChInsky, Larcen, Lochinan on aall economl sche $\mathrm{klassen}$ Solltinger (1976); Lor

- milde bare scholleren

GIIItesp Ia $(1977)$.

- (chronlsche) psychlatrlische Bedel, Archer en Marlow Jr. (1980); Edelsteln, petilenten Couturo, Cray, Dlckans en Lusebrink (1980); Melchenbaum (1977); Slegel en splvack (1976); Splvack, Platt en Shur (1976), Golldirlad (1980).

- studenten met beroepskeuza Magoon (1969); Hendonca on Sloss (1976); Coldproblemen frled (1980). 
- sudenten mot Interperscon- Melchenbaum (1977); Mayo en Norton (1980). IIIke angsten

- studenten met persoonlljke Arnkoff en Stewart (1975); Heppner (1978). probll emen

- studenten met studle-

Coldrrlad (1980); Mayo en Hortoll (1980). problemen

Tabe1 2.2. leidt tot de conclusie dat training in probleemoplossen bij uiteenlopende doelgroepen wordt toegepast. Dit soort programma's blijkt in verschillende settingen - geestelijke gezondheidszorg zowel als onderwijs - met ui teenlopende doelstellingen te worden uitgevoerd. Wat de doelstellingen betreft, is er sprake van preventieve zowel als therapeutische doeleinden.

De in dit overzicht behandelde auteurs geven een vrij concrete omschrijving van de categorieën clienten waarop hun methodiek is afgestemd. Goldfried en Davison (1976); D'Zurilla en Goldfried (1971) en J. Hollander (1980) doen een poging de in aanmerking komende clientcategorieën in meer algemene termen te vatten. D'Zurilla en Goldfried (1971) spreken over afhankelijke clienten met een adequaat gedragsrepertoire wat betreft algemene performance skills en clienten met emotionele blokkades. Goldfried en Davison (1976) richten zich vooral op clienten met tekorten in probleemoplossend vermogen en clienten met emotionele blokkades. J. Hollander (1980) benoemt de doelgroep in termen van aanpassing aan verandering: verandering van leefomgeving alsook verandering van (sociale) rol. Wat de persoonlijke vaardigheidstherapieën à la Goldstein betreft, komt de doelgroep zoals Hollander die omschrijft, veel meer in aanmerking voor deelname aan de in paragraaf 2.3.2. te beschrijuen vaardigheidstheraple "veranderingen aanpakken" dan voor deelname aan de in deze paragraaf behandelde vaardigheidstheraple "dagelijkse problemen aanpakken".

Wat clienten uit de lagere sociaal-economische klassen betreft, is traiming in problemoplossen relevant omdat clienten uit deze groep bij uitstek geconfronteerd worden met probleemsituaties waarvoar ze niet direct een adequat response-alternatief voor handen hebben (Rapaport, 1962; Schmidt, Smart en Moss, 1968). 
De vaardigheid "veranderingen aanpakken" is van toepassing wanneer het individu zelf bepaalde veranderingen wenst te realiseren in zijn (1evens)situatie. Deze veranderingen kunnen betrekking hebben op woon- of werkomgeving, dagindeling, eet-, drink- of slaapgewoontes, vrijetijdsbesteding en/of sociale contacten. Wie kiest voor verandering, heeft meestal een 1 ange weg te gaan. In de organisatiekunde spreekt men in dit kader over "planned change" (Bennis, Benne en Chin, 1973). Im de leertheoretische 1 iteratuur treft men het concept "behavioral selfcontrol" aan. Het meest wezenlijke aan het begrip "self-control" schuilt volgens Thoresen en Mahoney (1974) in het feit dat de persoon zelf "the agent of his own behavior change" vormt. Self-control of selfmanagementtrainingen worden voornapelijk toegepast in het kader van zelf-hulp. Doelgroepen en gekozen veranderingsdoelen lopen sterk uiteen. De betreffende therapieprogramma's zijn bedoeld om individuen, die zelf verandering(en) wensen aan te brengen in hun levenssituatie, een passende plannings- en uitvoeringsstrategie aan te leren. Men leert de deelnemers een aantal algemene gedragsveranderingsprincipes toe te passen op hun eigen gedrag.

Tabe1 2.3. geeft een overzicht van bestaande trainingsprogramma's die in dit kader relevant zijn.

Tabel 2.3. Overzl cht tralnIngsprograma's "wer ander Ingen aanpakken".

\begin{tabular}{|c|c|c|c|}
\hline Autheur & $\begin{array}{l}\text { Wiadere omschr lJving van } \\
\text { het programa }\end{array}$ & $\begin{array}{l}\text { Theme"s voor } \\
\text { verander Ing }\end{array}$ & $\begin{array}{l}\text { Onschr IJ wing } \\
\text { cl lentcategor lo }\end{array}$ \\
\hline $\begin{array}{l}\text { Coldd li amond } \\
(1965)\end{array}$ & 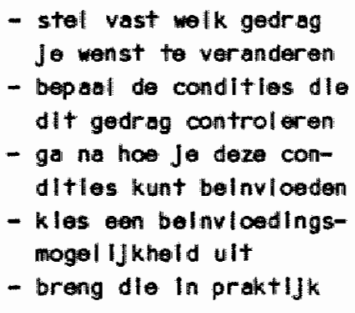 & $\begin{array}{l}\text { - overgew lcht } \\
\text { - stud leprobl emen } \\
\text { - huwel lJ Jik sproblemen } \\
\text { - probl emen m.b.t. } \\
\text { handschr Ift }\end{array}$ & $\begin{array}{l}=\text { Kl Inlsche pa- } \\
\text { tlenten }\end{array}$ \\
\hline $\begin{array}{l}\text { Kuenst ler } \\
(1976)\end{array}$ & Geon & $\begin{array}{l}\text { - structureren } \\
\text { wrlje tiju } \\
\text { - moell jlke token } \\
\text { aanpakken } \\
\text { - meuwe mensen } \\
\text { on trioeten } \\
\text { - lgen gedrag } \\
\text { verenderen }\end{array}$ & $\begin{array}{l}\text { - abulante psy- } \\
\text { chl atr l sche } \\
\text { potlenten } \\
\text { - recent gepen- } \\
\text { slioneerden }\end{array}$ \\
\hline
\end{tabular}




\begin{tabular}{|c|c|c|c|}
\hline Leo (1978) & 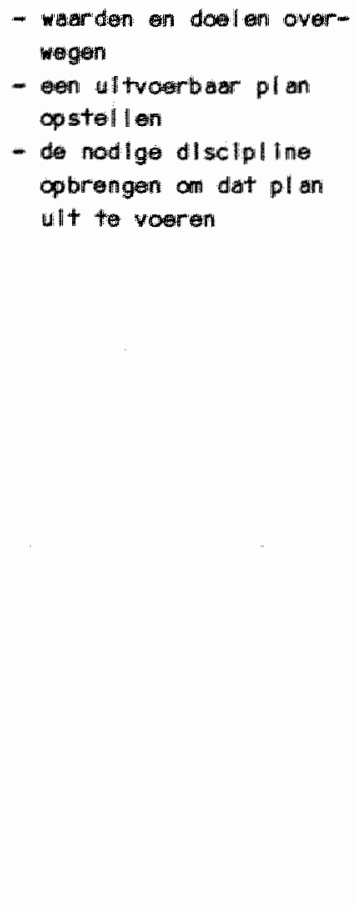 & 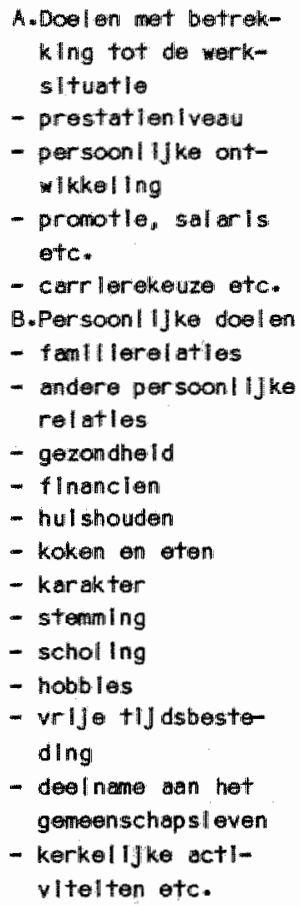 & $\begin{array}{l}\text { mensen die } \\
\text { zelf lets wll- } \\
\text { len wer anderen } \\
\text { (geon kllnl- } \\
\text { sche set+ling) }\end{array}$ \\
\hline Rosen (1981) & 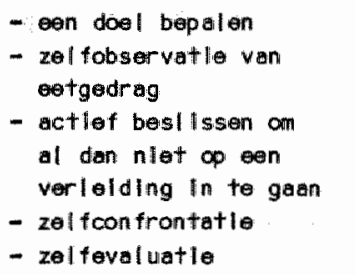 & - overgew l cht & $\begin{array}{l}\text { - menser met } \\
\text { overgew icht }\end{array}$ \\
\hline $\begin{array}{l}\text { Von dem Hart } \\
\text { Degenkamp on } \\
\text { Bos (1975) }\end{array}$ & 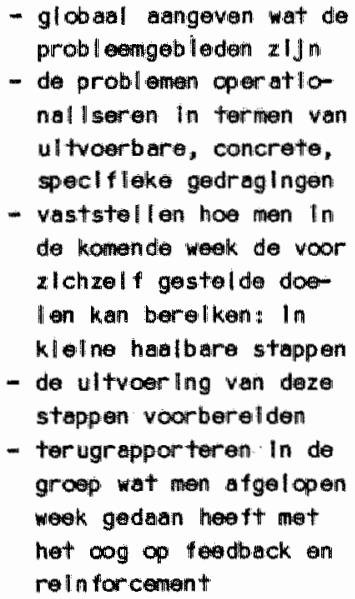 & $\begin{array}{l}\text { - alle onderwerpen } \\
\text { dle In het diage } \\
\text { lliks leven eem } \\
\text { rol spelen }\end{array}$ & $\begin{array}{l}\text { - ex-psychlatrl- } \\
\text { sche patienten } \\
\text { in nazorg }\end{array}$ \\
\hline
\end{tabular}




\begin{tabular}{|c|c|c|c|}
\hline $\begin{array}{l}\text { Whatson en } \\
\text { Tharp, } 1977\end{array}$ & $\begin{array}{l}\text { - ean doel klezen } \\
\text { - precles angeven wet er } \\
\text { moet veranderan om dat } \\
\text { doel te kunnen perelken } \\
\text { - zel fobservatle } \\
\text { - een plan opstellan } \\
\text { - dit plan zonodlg } \\
\text { aanpissan }\end{array}$ & $\begin{array}{l}\text { - otgedrag } \\
\text { - stud legewoontes } \\
\text { - rookgedrag } \\
\text { - ongeng met minderen }\end{array}$ & $\begin{array}{l}\text { - mon son dle } \\
\text { zonder hulp } \\
\text { vam begelel- } \\
\text { ders veran- } \\
\text { der Inglen tout } \\
\text { stand wensen } \\
\text { brengen }\end{array}$ \\
\hline $\begin{array}{l}\text { WIII ans en } \\
\text { Long, } 1975\end{array}$ & 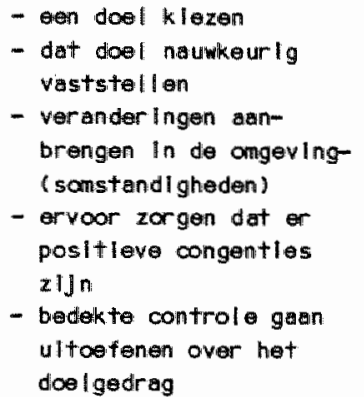 & $\begin{array}{l}\text { - overgew lcht } \\
\text { - sport/bewegl ing } \\
\text { - studilegewoonters } \\
\text { - carr lerepl anning } \\
\text { - nervositelt } \\
\text { - rel atleprobl men }\end{array}$ & $\begin{array}{l}\text { - wemsen die } \\
\text { zonder hulp } \\
\text { van begel wi- } \\
\text { ders verande- } \\
\text { rling(an) tot } \\
\text { stand wensen } \\
\text { te brengen }\end{array}$ \\
\hline
\end{tabular}

Uit tabel 2.3. blijkt dat:

- vrijwel alle auteurs adequate doelstelling en planning van de uitvoeringsfase als belangrijke tussenfasen in het veranderingsproces opvatten. De doelstellingsfase richt zich op het vertalen van globale, complexe, lange-termijn doelen in concrete, haalbare, kortetermijn doelen. De planningsfase dient de keuze van een actiestrategie en een concrete taakstelling in de tijd te garanderen.

- enkele programma's ook in een evaluatie- c.q. bijsturingsfase voorzien.

- dit soort programma's op uiteenlopende veranderingsdoelen (kunnen) worden toegepast.

- het bij deze programma's gaat on (het aanleren wan) een strategle gericht op modificatie van eigen (probleem)gedrag met behulp van leertheoretische principes en procedures.

- deze programma's meestal in een zelfhulp- c.q. preventie-kader worden toegepast.

- er meestal sprake is van het aanleren van drie deelvaardigheden: het kiezen van een doel; het maken van een plan en het structureren van de uitwoering daarvan. 
Op basis van bovenstaande informatie is besloten in de serie persoonlijke vaardigheldstherapieën ook een vaardigheid op te nemen, gericht op het zelfstandig tot stand brengen van verandering(en), omdat aangenomen wordt dat het beschikken over een dergelifke vaardigheid een noodzakelijke voorwaarde vormt tot effectief functioneren.

Bij de operationalisatie van deze vaardigheid werd uitgegaan van de eerdergenoemde 3 fasen: een doel kiezen, een plan maken en een uitvoeringsfase getiteld: "aan de slag gaan". Elk van deze fasen afzonderlijk werd geconcretiseerd met behulp van een drietal leerpunten. Deze leerpunten, tot stand gekomen op basis van literatuurgegevens en "try-outs" bif clientgroepen uit de lagere sociaal-economische klassen, luiden als volgt:

Veranderingen aanpakken

$\rightarrow$ Een doe1 kiezen

$$
\downarrow \begin{aligned}
& \text { 1. Ga na wat je wilt bereiken. } \\
& \text { 2. Ga na wat haalbaar is. } \\
& \text { 3. Kies een haalbaar doel. }
\end{aligned}
$$

Een p1 an maken
4. Ga na wat je eraan kunt doen.
5. Stel vast wanneer je wat gaat doen.
6. Bedenk aanpassingen bij mogelijke tegens 1 ag.

Aan de slag gaan

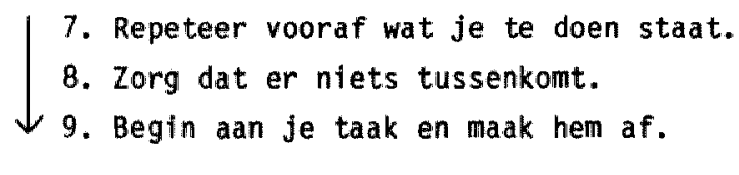

Het $k$ an noodzakel ijk zijn dat men deze leerpunten aan de hand van subdoellen meerdere malen moet doorlopen teneinde één bepaalde verandering tot stand te brengen. 


\subsection{3. "Beslissingen nemen"}

De derde vaardigheid in de hier besproken serie betreft het memen van beslissingen. Besluitwormingsprocessen worden in zeer verschillende disciplines bestudeerd 0.a. de geneeskunde, de economie, de politicologie, de geografie, de organisatiekunde en de psychologie. De aandacht voor de psychologische amalyse en verklaring wan het beslisproces is groejende zowel in descriptief als in normatief opzicht. (S10vic, Fischoff en Lichtenstein, 1977). Gullick (1979) stelt dat het nemen van beslissingen een voortdurend terugkerende activiteit is in elk menselijk leven, waarbij de te nemen beslissingen uiteraard variëren in complexiteit en belangrijkheid. Deze auteur onderscheidt de nu volgende elementen aan het beslisproces:

1. het oproepen, verzamelen, assimileren, sorteren, classificeren, evalueren en structureren van de benodigde informatie.

2. het formuleren van rationele al ternatieven.

3. het kiezen van een logische en coherente actie-strategie.

De criteria met behulp waarvan men de alternatieven weegt vooraf aan het besluit, worden volgens Gulick 1 ang niet altijd geëxpliciteerd. Het doel van het nemen van een beslissing is dat men uiteindelijk die respons weet te kiezen, die leidt tot effecten die consistent zijn met de voorkeur van degene die beslist.

Aldus onschreven lijkt er grote avereenstemming te bestaan tussen beslufitvorming en problemsolving. Ook Brim e.a. (1962) achten probleemoplossen en besluitvorming onderling verwisselbare processen waartussen slechts sprake is van een accentverschil: bij beslissingen nemen ligt volgens deze auteurs meer nadruk op het analyseren van de "be1 lefs" van de persoon met betrekking tot probability, toekomst en wenselijkheid, dan bij probleemoplossen het geval is. Volgens Slovic, Fischoff en Lichtenstein (1977) gaat het bij besluitvorming vooral om de wijze waarop met onzekerheden wordt omgegaan.

Tabe1 2.4. geeft een overzicht van de trainingsprogramma's in het nemen van beslissingem voor zover hier relevant. 


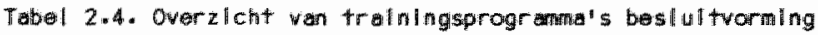

\begin{tabular}{|c|c|c|}
\hline Autrus & Nadare anschr IJ vling progir ande & Doelignoep \\
\hline $\begin{array}{l}\text { Bargl and, } \\
\text { Quatrano en } \\
\text { Lundqulst, } \\
1975 *\end{array}$ & 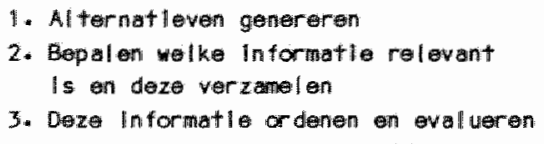 & $\begin{array}{l}\text { Studenten mett be- } \\
\text { roepskeuzeproblemen }\end{array}$ \\
\hline Blrk, $1976^{*}$ & $\begin{array}{l}\text { 1. Wer den-wer hel der lng } \\
\text { 2. Informatle verzineler } \\
\text { 3. Besil| issen }\end{array}$ & $\begin{array}{l}\text { Urouwell l jke scholl lo } \\
\text { ren met beroepseuze } \\
\text { probil emen }\end{array}$ \\
\hline De Long, 1978* & Gen & Gedet I neerdeni \\
\hline $\begin{array}{l}\text { Drumben } \\
\text { Knott, } 19177^{*}\end{array}$ & 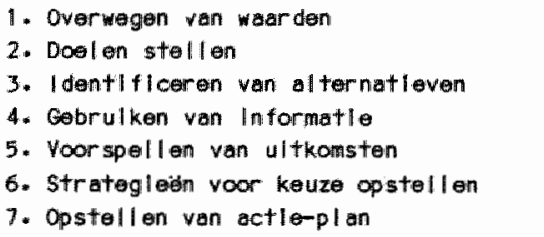 & $\begin{array}{l}\text { Ultenlopende popur } \\
\text { latles; preventlef }\end{array}$ \\
\hline
\end{tabular}

\begin{tabular}{|c|c|c|}
\hline $\begin{array}{l}\text { Evans en } \\
\text { Cody. } 1969^{*}\end{array}$ & 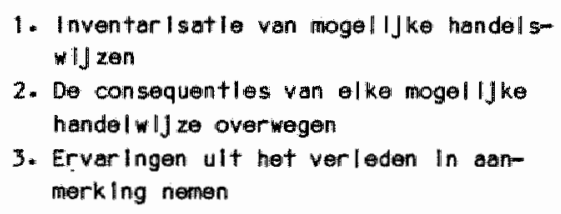 & studenten \\
\hline $\begin{array}{l}\text { Farguson, } \\
1976^{*}\end{array}$ & $\begin{array}{l}\text { 1. Waerden-verhel der Ing } \\
\text { 2. Het probleen ldentl fl ceren } \\
\text { 3. Informatle verzamelen } \\
\text { 4. Alternatleven bedenken } \\
\text { 5. Alternatlewen evall veren } \\
\text { 6. Klezien }\end{array}$ & $\begin{array}{l}\text { studenten net be- } \\
\text { roepskeuzeproblemen }\end{array}$ \\
\hline
\end{tabular}

\begin{tabular}{|c|c|c|}
\hline Frasler, 1975* & Geen & $\begin{array}{l}\text { Milddel bare schol le- } \\
\text { ren }\end{array}$ \\
\hline Golltit, $1962^{*}$ & 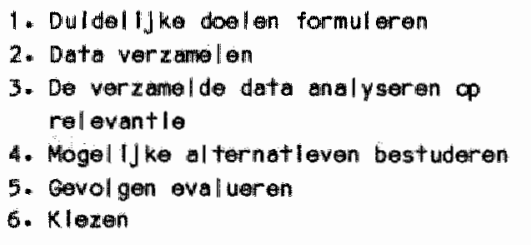 & $\begin{array}{l}\text { Studenten met be- } \\
\text { roopskeuzeproblimen }\end{array}$ \\
\hline $\begin{array}{l}\text { Coldsteln, } \\
1976.1981 \text {. }\end{array}$ & 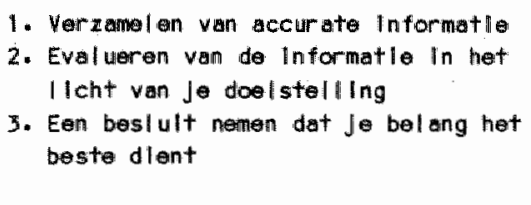 & $\begin{array}{l}\text {-Psychlatrlsche } \\
\text { patlenten } \\
\text {-Oudars dle hum kln- } \\
\text { deren mishandelen } \\
\text {-Palltle-agenten } \\
\text { - Adolescemten }\end{array}$ \\
\hline
\end{tabular}




\begin{tabular}{|c|c|c|}
\hline $\begin{array}{l}\text { Greenwald, } \\
\text { 1973* }\end{array}$ & $\begin{array}{l}\text { 1. Zelf besllisen al daini nllet te ver- } \\
\text { anderen } \\
\text { 2. Deze besllissing ook untwoeren } \\
\text { 3. Alternatieven bedenken } \\
\text { 4. Een alternatlef ultklezen }\end{array}$ & Neuratlsche cl lenter \\
\hline Grish am, $1978^{*}$ & Geen & $\begin{array}{l}\text { Economl sch achtar- } \\
\text { gestelde lomgeran }\end{array}$ \\
\hline Halpern, 1967* & 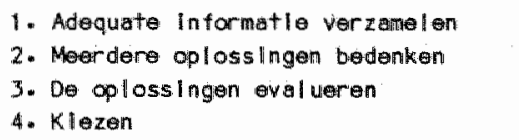 & Studentan \\
\hline
\end{tabular}

\begin{tabular}{|c|c|c|}
\hline Hoogdulin, $1980^{*}$ & $\begin{array}{l}\text { 1. Deflnleren van het keuzeprobleam } \\
\text { 2. Hat genereren vam argumenten } \\
\text { voor en tegen } \\
\text { 3. Waar der ling van de argumenten } \\
\text { 4. Ultwcer ling van de genomen besll is }\end{array}$ & Neurot I sche cl lenten \\
\hline
\end{tabular}

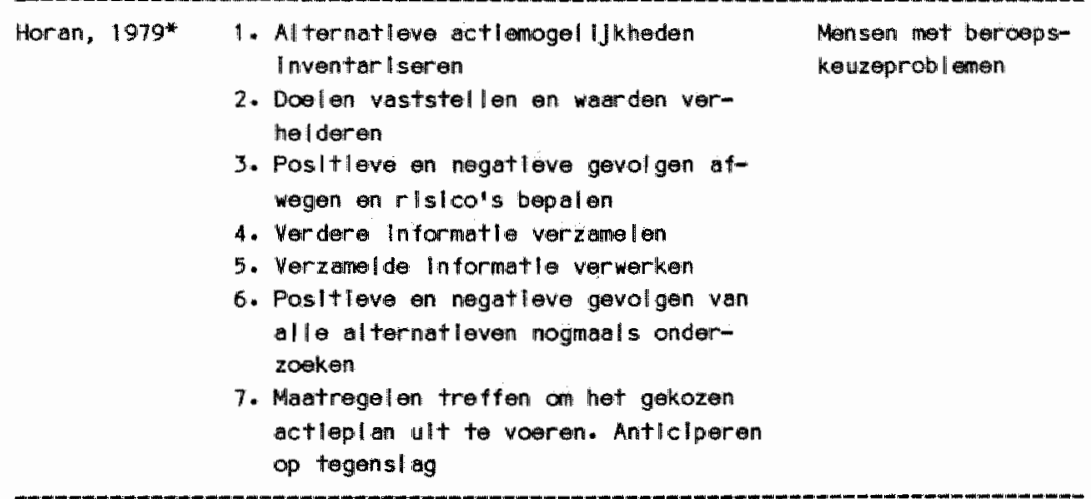

Janls en Hoyt, 1. Onderkennen dat or lets moet gebeuren

Studenten met be1975* 2. Onderkennen van mogel ljke handel Ingsstrateglledn

3. Voorloplge selectlo wan handellingsstrategleen

4. Kauze woor bon bopalde handellingsstrataglo

5. Vasthouden aan deze keuze ongeacht eventule negatleve teodback roepskeuzeproblemen 


\begin{tabular}{|c|c|c|}
\hline $\begin{array}{l}\text { olson en Grom- } \\
\text { berg, } 1972^{*}\end{array}$ & Goon & $\begin{array}{l}\text { Psichlatr I sche } \\
\text { patlonten }\end{array}$ \\
\hline $\begin{array}{l}\text { Russell en } \\
\text { Thoresen. } \\
\text { 1976. }\end{array}$ & 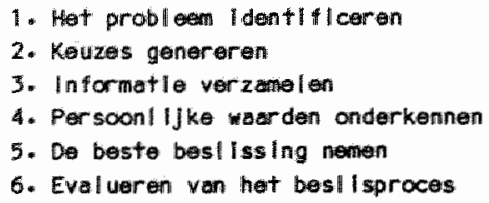 & $\begin{array}{l}\text { Yorwar loosde en } \\
\text { agressleve ado- } \\
\text { lescenten }\end{array}$ \\
\hline
\end{tabular}

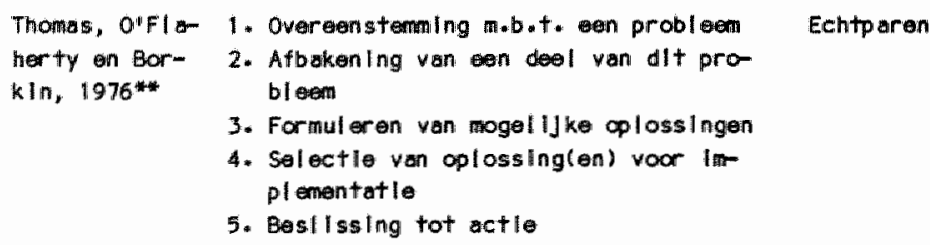

\begin{tabular}{|c|c|c|}
\hline $\begin{array}{l}\text { Wall lace, Horan, } \\
\text { Baker on Hud- } \\
\text { son, 1975* }\end{array}$ & 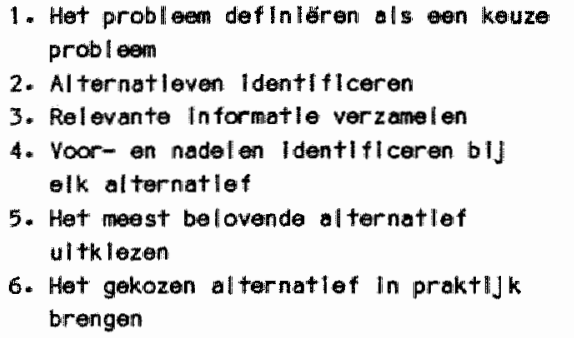 & $\begin{array}{l}\text { Colunselors in } \\
\text { oplelding }\end{array}$ \\
\hline Yabroft, 1969" & $\begin{array}{l}\text { Geen. Bencemt als voorwarden tot ade- } \\
\text { quate besluitvormilng: } \\
\text { - beschlkbaarheld wan rel evamte Informatle } \\
\text {-kennls van alle denkbare all ternatleven } \\
\text {-kunnen inschatten van alle denkbare } \\
\text { gevolgen }\end{array}$ & $\begin{array}{l}\text { Studenten met be } \\
\text { roopskeuzeproblemen }\end{array}$ \\
\hline
\end{tabular}

* In ander Ujsset+ing

* In geesitel ljke gezondheldszorg

Uit tabel 2.4. blijkt dat toepassing van trainingen in het nemen van beslissingen vooral plaats vindt op het terrein van onderwijs en beroepskeuze. Toepassingen in de geestelijke gezondheidszorg zijn vooralsnog schaars. Uit deze tabel blijkt bovendien dat er geen sprake is van een uniform basismodel zoals dat bij probleemoplossen het geval bleek. Nadere inspectfe wan tabel 2.4. leidt tot de conclusie dat adequate informatie-verzameling en reductie van onderzekerheden in vrijwel elk programina een rol spelen.

Ervan uitgaande dat probieemoplossen en beslissingen nemen van elkaar 
onderscheiden vaardigheden vormen "besloot de Goldsteinprojectgroep naast de in 2.3.1. beschreven vaardigheid "dagel ijkse problemen oplossen" ook een vaardigheid "beslissingen nemen" te ontwikkelen.

Aansluitend aan de in tabel 2.4. beschreven literatuur koos men voor een vaardigheid "beslissingen nemen" waarbij het leren omgaan met twijfels/onzekerheden en het (leren) kiezen tussen reeds beschikbare alternatieven centraal staan. Het genereren van keuzemogelijkheden c.q. formuleren van alternatieven wordt gerekend tot het domein van de vaardigheid "dagelijkse problemen aanpakken". De vaardigheid "beslissingen nemen" spitst zich toe op het inventariseren en met behulp van relevante informatie reduceren van de onzekerheden, die aan elke keuze verbonden zijn. Een en ander heeft geleid tot de nu volgende operationalisatie qua leerpunten.

1. Ga na voor welke keuze je staat.

2. Zet je twijfels op een rij.

3. Ga na welke informatie de twijfels kan verminderen.

4. Yerzamel die informatie.

5. Weeg de keuze-mogelijkheden af, met die informatie.

6. Neem je beslissing: kies.

De aldus omschreven vaardigheid kan als een concretisering worden opgevat van leerpunt 4 uit de vaardigheid "dagelijkse problemen aanpakken": Kies de oplossing die je het beste past.

In de serie persoonlijke vaardigheidstherapieën heeft de vaardigheid "beslissingen nemen" de functie van hulpvaardigheid. Het aanleren van deze vaardigheid wordt niet als een apart programma aan clienten aangeboden maar ingepast in de programma's "dagelijkse problemen aanpakken" en "veranderingen aanpakken", wanneer blijkt dat de deelnemers deze hulpwaardigheid onvoldoende beheersen.

Een en ander is gebaseerd op de veronderstelling dat clienten in de geestelijke gezondheidszorg hun problemen vrijwel noolt direct presenteren in termen van beslisproblemen. De vaardigheidstherapieën "dagelijkse problemen aanpakken" en "veranderingen aanpakken" lijken in dit opzicht beter aan te sluiten bij het subjectieve probleembewustzijn van $c l$ ienten in de geestelijke gezondheidszorg. Vaardighefd in het nemen van beslissingen wordt dus als een noodzakelijke doch niet tevens 
voldoende voorwaarde opgevat voor het volgens de leerpunten aanpakken van "dagelijkse problemen" zowel als "veranderingen".

\subsection{4. "Informatle verzamelen"}

In de literatuur zoals die tot nu toe besproken werd met betrekking tot de vaardigheden "dagelijkse problemen aanpakken", "besilissingen nemen" "en "veranderingen aanpakken", benadrukken diverse auteurs het belang van adequate informatieverzameling. Zij gaan ervan uit dat het adequat stellen wan bovengenoemde vaardigheden alleen mogelijk is wanneer het betreffende Individu over de vaardigheid beschikt om informatie te verzamelen (zie ook Bourne, Ekstrand en Dominovski, 1971; Davis, 1973; Davis, Train en Manske, 1968; Duncan, 1963).

In de door de Goldsteinprojectgroep vastgestelde operationele definitle wan de vaardigheid "beslissingen nemen" vormt het verzamelen van informatie een apart leerpunt: leerpunt 4. De wijze waarop men deze informatie verzame1t, wordt daarbij niet nader omschreven. Tabe1 2.5 geeft een overzicht van trainingsprograma's - in probleemoplossen danwel besluitvorming - die het belang van het verzamelen van informatile benadrukken.

\begin{tabular}{|c|c|c|c|c|}
\hline Auteurs & $\begin{array}{l}\text { nagasn } \\
\text { welke. In- } \\
\text { format le } \\
\text { nodlg is }\end{array}$ & $\begin{array}{l}\text { Informatie ver- } \\
\text { zamel am, orde- } \\
\text { nem, sarnenwat- } \\
\text { vatten }\end{array}$ & $\begin{array}{l}\text { de Informatle } \\
\mathrm{kr} \|+\mathbf{t} \text { sch ewa- } \\
\text { Iueren }\end{array}$ & $\begin{array}{l}\text { anschr ld ving } \\
\text { cll lentcategor le }\end{array}$ \\
\hline Adte Ins, 1970 & + & 4 & + & $\begin{array}{l}\text { - mensen in achterstand } \\
\text { sltuat las }\end{array}$ \\
\hline $\begin{array}{l}\text { Arnkoff an } \\
\text { Stawert, } 1975\end{array}$ & $=$ & + & $\because:$ & $\begin{array}{l}\text { - studenten wet persoon- } \\
\text { l ljke problemen }\end{array}$ \\
\hline $\begin{array}{l}\text { Drum an } \\
\text { hrott, } 1977\end{array}$ & - & + & + & $\begin{array}{l}\text { - ulteen lopende doal- } \\
\text { groepen met preventle } \\
\text { doelstel IIng }\end{array}$ \\
\hline $\begin{array}{l}\text { Coldsteln, } \\
1973,1976 \\
1980\end{array}$ & $*$ & + & $m$ & $\begin{array}{l}\text {-psychlatr I sche } \\
\text { patlenten } \\
\text { - bejaerdan } \\
\text {-adollescenten }\end{array}$ \\
\hline
\end{tabular}




\begin{tabular}{|c|c|c|c|c|c|}
\hline Ka & 1973 & - & + & + & 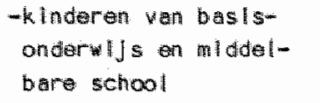 \\
\hline Mogor. & 1969 & - & 4 & + & $\begin{array}{l}\text { - studenter mot boroeps- } \\
\text { keuzeprobl smen }\end{array}$ \\
\hline
\end{tabular}

* = WEL AMNWEZIG

- = NIET AANWEZIG

Hollander (1980**), Mendonca en Siess (1976*); Stone, Hinds en Schmidt (1975**), Yabroff (1969*) benadrukken het belang van "informatie verzamelen" in relatie tot probleemoplossen en besluitvorming, overigens zonder het informatie-verzamel-proces operationeel te definiëren. Waarbij * verwijst naar toepassingen in een onderwijssetting en ** naar toepassingen in een geestelijke gezondheidszorgsetting.

Uit tabel 2.5. blijkt dat:

- het verzamelen, ordenen, en samenvatten van informatie door alle 6 auteurs genoemd wordt.

- het kritische evalueren van de verzamelde informatie door 4 van de 6 auteurs genoemd wordt.

Uit ervaringen met clienten uit de lagere sociaal-economische $k l$ assen blijkt dat veel clienten uit deze doelgroep een vaardigheidstekort vertonen wat het verzamelen van informatie betreft. Als men al zover komt dat men inderdaad informatie verzamelt, neent men vaak genoegen met informatie uit de zoveelste hand. Dit gegeven vormde voor de Goldsteinprojectgroep een reden te meer om een vaardigheid "informatie verzamelen" in het pakket persoonlijke vaardigheidstherapieën op te nemen. Deze vaardigheid werd geoperationaliseerd met behulp van de volgende leerpunten:

1. Ga na welke informatie je nodig hebt.

2. Bedenk manieren waarop je aan deze informatie kunt komen.

3. Kies daaruit de beste manier(en).

4. Maak een plan van wat je moet gaan doen.

5. Voer dat plan uit.

6. Zet de verzamelde informatie op een rij. 
De valardigheld "Informatie verzamelen" heeft dezelfde taak en functie binmen het pakket persoonlijke vaardigheden als de vaardigheid "beslissingen nemen". De vaardigheid "informatie verzamelen" wordt ook niet als programma "an sich" aan clienten aangeboden maar vormt een onderdeel van de vaardigheidstherapie "dagelijkse problemen aanpakken" danwe1 "veranderingen aampakken". 
HOOFDSTUK 3. BESCHRIJVING VAN DE WIJZE WAAROP DE PERSOONLIJIKE VAARDIGHEIDSTHERAP IE-PROGRAMMA'S WORDEN UITGEVOERD

\subsection{INLEIDING}

In dit hoofdstuk wordt beschreven hoe de persoonlijke vaardigheidstherapieën worden uitgevoerd. Besproken wordt de wijze waarop modeling, gedragsoefening, bekrachtiging en transfertraining vorm krijgen tijdens de groepsbijeenkomsten. 0ok wordt aandacht besteed aan indicaties voor deelname op vaardigheidsniveau. De door de projectgroep ontwikkelde therapie-protocollen worden gepresenteerd. Deze protocollen zijn bedoeld ais handleiding voor therapeuten die deze vaardigheidstherapieën in praktijk brengen.

Deelname aan de hier beschreven vaardigheidstherapieën vormt geen behandeling op zich maar maakt steeds deel uit van een meer omvattend individueel behandelingsplan. Aan deze therapie-vorm deelnemende clientem zijn meestal reeds sinds langere tijd in behandeling bij een ambulante danwel klinische instelling voor Geestelijke Gezondheidszorg. De clienten worden door hun hoofdbehandelatar voor deelname aan een of meerdere vaardigheidstherapie(ën) doorverwezen. Na beëindiging van de vaardigheidstherapie(ën) wordt de behandeling voortgezet door de oorspronkelijke hoofdbehandelaar c.q. verwijzer. Vanwege de gewenste continuiteit in de behandeling wordt deze laatste op de hoogte gebracht van datgene wat client werd aangeleerd tijdens de persoonlijke vaardigheidstherapie. Bij deze informatie-overdracht wordt vooral aandacht besteed aan de wijze waarop de hoofdbehandelaar c.q. verwijzer de uitwoering van de nfeuw aangeleerde vaardigheid door de cllent kan bl ijven stimuleren en bekrachtigen (zie ook paragraaf 3.2.3.1.).

3.2. OPERATIONALISATIE VAN DE BASISCOMPONENTEN UIT GOLDSTEIN'S METHODE

Goldstein (1973), Goldstein e.a. (1976) hanteren de wit de sociale leertheorie afgeleide principes modeling, gedragsoefening, bekrachti- 
ging en transfertraining als uitgangspunt bij de ontwikkeling en witvoering van de door hen ontworpen vaardigheidstherapie van mening dat deze principes op dezelfde wijze van toepassing zijn bij het aanleren van intempersoonlijke en persoonlijke vaardigheden. Tijdens de uitvoering van persoonlijke en interpersoonlijke vaardigheidstherapleën streeft men zijns inziens immers dezelfde doelstelling na, namelijk de deelnemers een nauwkeurig omschreven handelingsstrategie aan te leren met betrekking tot een bepald doelgedrag. Het feit dat bif de interpersoonlijke vaardigheidstherapieën de nadruk iigt op het aanleren van handelingsstrategieën met het accent op overt gedrag en bij de persoonlijke vaardigheidstherapieên op covert gedrag, is zijns inziens van ondergeschikt belang. All experimenterend met de uitvoering van de persoonlijke vaardigheidstherapie-programma's $\mathrm{kwam}$ de Goldsteinprajectgroep echter tot de conclusie dat de typische eigen aard van de persoonlijke vaardigheden wel degelijk aanpassingen in de vomgeving van de hoofdcomponenten noodzakelijk makte.

Alworens tot de meer gedetaj1leerde beschrijuing van deze aanpassingen over te gaan, wordt eerst de algemene opzet van de persoonlijke vaardigheidstherapieèn weergegeven. Elk programma is gericht op het aanleren van ëen bepaalde vaardigheid. De therapie wordt uitgevoerd door twee therapeuten dife de groepsbijeenkomsten leiden. Per aan te leren vaardigheid is er sprake van 4 a 8 wekelijkse bijeenkomsten van elk 2 uur. Aan elke vaardigheidstherapie nemen minimaal 5 en maximaal 8 clienten deel. De deelnemers zijn allen mensen met een lager inkomen, lagere beroepsstatus en lager opleidingsniveau en reeds sinds langere tijd in behandeling, ambulant danwel $\mathrm{klinisch,} \mathrm{bij} \mathrm{een} \mathrm{instelling} \mathrm{voor}$ geestelijke gezondheidszorg. Een client wordt woor deelname aan een vaardigheidstheraple verwezen vanwege gedragstekorten ten aanzien van de betreffende vaardigheid. De vaardigheidstherapieën worden uitgevoerd in een groepsruinte van $\pm 50 \mathrm{~m}^{2}$ waarin de stoelen in U-vorm stalan opgesteld. Vanult hun stoelen dienen de deelnemers een goed uitzicht te hebben op het zogenaamde speelvlak: dàt deel van de ruimte warin gedragsoefening en modeling plaatsvinden. Als hulpmiddelen dienen bovendien in de ruimte aanwezig te zijn: een video-afspeelunit, een bord met daarop de betreffende leerpunten (=poster), een 
flap-over, een viltstift, een stapel zogenaamde huiswerkboekjes en pennen of potloden.

Na deze algemene opmerkingen ten aanzien van setting en therapeutische hulpmiddelen zullen in het nu volgende de wijzen worden beschreven warop modeling, gedragsoefening, (sociale) bekrachtiging en transfertraining worden geoperational iseerd.

\subsubsection{Modeling}

In hoofdstuk 1 werd reeds aangegeven dat modelingsprocessen een beIlangrijke rol spelen in de door Goldstein (1973) ontworpen leermethode (zie ook paragraaf 1.4.2.). 0ok voor de in Mastricht ontwikkelde variant op de Goldsteinmethode geldt dat het modelingsprincipe een belangrijke plaats inneemt in het leerproces. Zowel tijdens de interpersoonlijke als tijdens de persoonlijke vaardigheidstherapleën wordt aan dit principe op twee uiteenlopende wijzen vorm gegeven, namelijk met behulp van video-voorbeelden en met behulp wan voorbeelden "in levende lijve" (=live-modeling). In het mul volgende zal worden beschreven hoe een en ander in concreto gerealiseerd wordt.

\subsubsection{Video-model ing}

Voor elk van de persoonlijke vaardigheldstherapleën werd een videoprogramma ontwikkeld, waarin de betreffende vaardigheid in zijn diverse aspecten wordt getoond. De opbouw van deze videoprogramma's is standaard. De redenen waarom de Goldsteinprojectgroep video-model Ing verkoos boven modeling door middel van geluidsbanden, zijn reeds beschreven in paragraaf 1.5 .2 .

ledere videoband begint met een inleiding door een ter zake deskundige autoriteit waarin de leerpunten worden behandeld en het nut van de betreffende vaardigheid benadrukt. Daarna worden een drietal voorbeeldsituaties getoond, warin de vaardigheid in praktijk wordt gebracht door verschillende hoofdrolspelers. De getoonde sltuatles betreffen achtoreenvolgens openbaar leven, gezin en werk. Net als bij de inter- 
persoonlifke vaardigheidstherapieen worden deze woorbeeldsituatles bij drie van de vier persoonlijke vaardigheidstherapie-programa's "dagel ijkse problemen aanpakken", "beslissingen nemen", en "informatie verzamelen" - in de vorm van contrastparen aan de kijker aangeboden. Contrastparen wat betreft het wèl en nièt toepassen van de betreffende leerpuntensequentie. Het aanbieden van contrastparen heeft immers als woordeel dat daardoor discriminatie van relevante aspecten - dat wil zeggen de leerpunten - vergemakkelijkt wordt. Deze contrastparen worden elk door één en dezelfde hoofdrolspeler vertolkt (voor een nadere toelichting zie ook paragraaf 1.5 .2$.$) .$

Het videoprogramma "veranderingen aanpakken" omvat 4 voorbeeldsituaties, waarin de betreffende leerpunten wél worden toegepast. Er worden geen contrastparen aangeboden vanwege het feit dat men er niet in slaagde een in de vorm van contrastparen samengestelde, discriminatie van de betreffende leerpuntensequentie bevorderende, weergave van de gepresenteerde voorbeeldsituaties te ontwikkelen. Van de in het programma getoonde voorbeeldsituaties worden er 3 , opgedeeld in fragmenten, aan de kijker aangeboden. Deze 3 fragmenten betreffen achtereenvolgens "een doel stellen", "een plan maken" en "aan de slag gaan". Het vierde voorbeeld wordt in totaliteit aan de kijkers gepresenteerd. Het videoprogramma "veranderingen aanpakken" is al svolgt opgebouwd:

- inleiding met betrekking tot "veranderingen aanpakken" door een autoriteit.

- inleiding door dezelfde autoriteit nu met betrekking tot "een doel stellen".

- 3 voorbeelden warin men 3 verschillende hoofdpersonen "een doel ziet stellen".

- inleiding door autoriteit met betrekking tot "een plan maken".

- 3 voorbeelden waarin men de eerder getoonde hoofdpersonen "een plan zlet maken".

- Inleiding door autoriteit met betrekking tot "aan de slag gaan".

- 3 voorbeelden waarin men de eerder getoonde hoofdpersonen "aan de slag ziet gaan".

- voorbeeld 4 waarin men een hoofdpersoon volgt die de leerpunten 1 t/m 9 integraal toepast. 
Bij de samenstelling van de video-programma's voor de persoonlijke vaardigheidstherapieën werd rekening gehouden met de door Goldstein (1973) geinventariseerde richtlijnen ter optimalisering van het modelingsprincipe. Voor een overzicht van deze zgn. "modeling enhancers" zie paragraaf 1.4.1. De leerpuntensequenties waruit de persoonlijke vaardigheden zijn opgebouwd, hebben vrijwel allen betrekking op covert gedrag. Deze leerpunten worden door de in de videoprogramma's optredende hoofdrolspelers "hardop denkend" toegepast, soms in de vorm van een monoloog, soms ook in dialoog met een antagonist. De gepresenteerde video-voorbeelden beogen de deelnemers een realistisch beeld te geven van de betreffende vaardigheid in zijn praktische toepassing. Door middel van deze voorbeelden streeft men ernaar adequate responsinformatie over te brengen aan de deelnemers.

Kijkend naar de video-programma"s, worden de deelnemers op het spoor gezet van situaties en thema's uit de eigen leefsituatie, die voor het toepassen van de betreffende vaardigheid in aanmerking komen. De video-voorbeelden vormen voor de therapeuten een belangrijk hulpmiddel om de leerpunten te verduidelijken. Tijdens de eerste groepsbijeenkomsten neemt video-modeling een centrale plaats in. In de daaropvolgende bijeenkomsten raakt deze vorm van modeling steeds meer op de achtergrand. Live-modeling oftewel modeling "in levende lijve" door de dee1nemers voor elkaar, neemt dan de plaats en functie van video-modeling over.

\subsubsection{Modeling in levende lijue}

Vanaf de tweede groepsbijeenkamst wordt de video-modeling steeds meer vervangen door modeling wan de groepsdeelnemers voor elkaar. Binmen de veilige muren van de groepskamer laat men elkaar zien hoe men de betreffende leerpuntensequentie in eigen situaties kan toepassen. Wanneer een van de deelnemers niet in stat blijkt de leerpuntensequentie meteen zelf op de door hem ingebrachte probleem-situatles toe te passen, schakelen de therapeuten één of meer overige groepsleden als model $i$. De therapeuten schakelen alleen diegenen als model in, waarvan duidelijk is dat zij de betreffende leerpuntensequentle voldoende be- 
heersen. De modellen krijgen als opdracht van de therapeut de betreffende leerpuntensequentie op de door hun medegroepsilid ingebrachte situatie toe te passen. De therapeut schakelt per situatie minimaal 2 modellen in. Deze modellen treden na elkaar op, op het speelvlak in front van de groep, duidelijk zicht- en hoorbaar voor de toeschouwende mede-groepsleden. De madellen passen de betreffende leerpuntensequentye "hardop denkend" toe, gezeten in een stoel die op het speelvlak staat opgesteld. Het model zit "en profile" voor de groep, de ogen gericht op het bord met leerpunten. Na afloop van elke modeling vindt er een nabespreking plaats waarbij de leerpuntensequentie als richt$11 j \mathrm{jn}$ dient. Degene voor wie de modeling vooral bestemd is, dat wil zeggen, degene die de betreffende situatie heeft ingebracht, krijgt als opdracht van de therapeut goed op te letten hoe het model de betreffende leerpunten toepast. Nadat het model de situatie met behulp van de leerpunten heeft afgerond, vraagt de therapeut aan degene die de situatie heeft ingebracht, welke deelgedragingen hij van het geobserveerde model wenst over te nemen.

Bij "dagelijkse problemen aanpakken"; "beslissingen nemen" en "informatie verzamelen" wordt er tijdens de eerste groepsbijeenkomst geoefend met behulp van standaard-situaties. De therapeuten modelen samen op welke wijze de oefenbeurten met standaard-situaties verlopen. Men gaat op dezelfde wijze te werk als bij modeling ten aanzien van door deelnemers zelf ingebrachte situaties.

\subsubsection{Gedragsoefening}

Gedragsoefeningen - tijdens de groepsbijeenkomsten èn in de eigen leefomgeving - vormen een centraal onderdeel van de gehanteerde leermethode.

In relatie tot de interpersoonlijke vaardigheidstherapieën worden drie vormen van gedragsoefening onderscheiden, te weten: imiterende gedragsoefening, anticiperende gedragsoefening en reconstruerende gedragsoefening. Voor een beschrijuing van de wijze waarop deze vormen van gedragsoefening, in relatie tot de interpersoonlijke vaardigheidstherapieën, ook wel rallenspelen genoend, worden uitgewerkt, zie Bee- 
kers (1982). Ten aanzien van de persoonlijke vaardigheldstherapieèn blijken andere vormen van gedragsoefening aangewezen dan bij de interpersoonlijke vaardigheidstherapieën. Voor zowel persoonlijke als interpersoonlijke vaardigheidstherapieën geldt dat gedragsoefening plaats vindt tijdens de groepsbijeenkomsten en in de eigen leefsituatie. Wat de persoonlijke vaardigheldstherapieën betreft, kan inen vijf vormen van gedragsoefening onderscheiden, te weten:

- gedragsoefening met behulp van standaard-situaties

- anticiperende gedragsoefening

- reconstruerende gedragsoefening

- schriftelijke gedragsoefening

- gedragsoefening in spelvorm.

Zoals bij de interpersoonlijke vaardigheidstherapieën de interactie van het individu met andere personen wordt ingeoefend, zo wordt bij de persoomlijke vaardigheidstherapieën de interactie van het individu met een door hem als problematisch erwaren situatie geoefend. Terwijl bij de interpersoonlijke vaardigheidstherapieën de ontmoeting met de ander daadwerkelijk in scene wordt gezet in het hier en nu van de groepssituatie, wordt bijj de persoonlijke vaardigheidstherapieën de problematische situatie meestal alleen verbal geschetst en "in imagine" aanwezig verondersteld.

In het nu volgende zal elk van de bovengenoemde vormen van gedragsoefening afzonderlijk worden besproken.

3.2.2.1. Gedragsoefening met behulp van standaard-situaties

Bij de interpersoonlijke vaardigheidstherapieën wordt tijdens de eerste groepsbijeenkomsten imiterende gedragsoefening toegepast. Na vertoning van het video-model waarin de betreffende leerpuntensequentie wordt toegepast, krijgen alle groepsleden successievelijk opdracht tot imitatie van het gedrag van de hoofidrolspeler op het speelviak. Bij de praktische uitvoering van de persoonlijke vaardigheidstherapieën bleek echter al heel snel dat deze imiterende gedragsoefening een andere functie vervulde dan bij de interpersoonlijke vaardigheidstherapieän. Imftatie van de video-modellen werd meer een training in geheugen- 
functie dan een daadwerkelijke eerste ervaring met de toepassing van de betreffende leerpuntensequentie. op grond van deze bevindingen, werd besloten deze wom van gedragsoefening nlet op de persoonlijke vaardigheidstherapieên van toepassing te doen ziJn. Er werd een passend alternatief ontwikkeld in de zin wan gedragsoefening met behulp van standaard-situaties. Bij de persoonlijke vaardigheidstherapieën "dagelijkse problemen aanpakken"; "beslissingen nemen" en "informatie verzamelen" wordt tijdens de eerste twee groepsbijeenkomsten geoefend met standaard-situaties. Het oefenen met behulp wan standaard-situaties wordt gemodeld door de therapeuten alvorens de groepsdeelnemers aan de beurt komen. Doel van deze vorm van gedragsoefening is

- clienten vertrouwd te maken met gedragsoefening als leermiddel

- clienten in stat te stellen eerste ervaringen op te doen met de aan te leren vaardigheld

- therapeuten inzicht te geven in de gedragstekorten, mogelijkheden en beperkingen van de client.

Voor een overzlicht van een lijst met relatief eenvoudige standaardsituaties, zie de door de projectgroep ontwikkelde handleidingen voor therapeuten (bijlage I). Gegeven het wanuit de sociale leertheorie afgeleide basisprincipe, dat de vaardigheidstherapieën erop gericht dienen te zijn de persoonlijke competentie-verwachtingen van de deelnemers te versterken door middel van succesvolle toepassing van de betreffende vaardigheid (Bandura, 1977), is het van groot belang dat de therapeuten de eerste gedragsoefeningen afstemmen op het laanvanke$1 \mathrm{jjk}$ nog lagel competentieniveau van de deelnemers op dat moment. Vanuit dat niveaw wordt vervolgens verder opgeklommen volgens een speciaal op het indiwidu afgestemde hiërarchie qua moeilijkheidsgraad. De standard-situaties vormen bovendien hulpmiddelen om de deelnemers duldelijk te maken, welk soort situaties voor gedragsoefening in de groep in aanmerking komen.

Bij de vaardigheidstherapie "veranderingen aanpakken" wordt geen gebruik gemakt van het oefenen met behulp van standaard-situaties. Men start meteen met oefeningen ten aanzien van zelf ingebrachte situaties. Een en ander in samenhang met de typische eigen aard van deze vaardigheid, gericht op het realiseren wan door individuen zelf gewenste veranderingen, in tegenstelling tot veranderingen die door anderen worden opgelegd. 
Bij de vaardigheidstherapieëm "dagelijkse problemen aanpakken", "beslissingen nemen" en "informatie verzamelen" wordt in de derde bijeenkomst een schriftelijke gedragsoefening uitgevoerd. Een van beide therapeuten presenteert een standaardsituatie (zie lijst met standaardsituaties in bijlage I) aan de groepsdeel nemers met als opdracht de betreffende leerpuntensequentie op deze situatie toe te passen. De co-therapeut deelt pen en papjer uit aan de deelnemers. De mogelijkheid tijdens deze oefening aantekeningen te maken, blijkt uit ervaring een noodzakelijke geheugensteun te vormen en het overzicht over de toe te passen leerpuntensequentie te bevorderen. Deelnemers die niet kumnen schrijuen, worden zo onopvallend mogelijk, geholpen door een van beide therapeuten. Na beëindiging van het denk- en opschrijfwerk wordt de concrete invulling van de leerpuntensequentie "en groupe" nabesproken. Deze nabespreking dient als feedback op de individuele toepassing van de leerpuntensequentie.

Doel van deze vorm van gedragsoefening is:

- de deelnemers model te doen zijn ten opzichte van elkaar wat het zelfstandig toepassen van de leerpuntensequentie betreft.

- de deelnemers in staat te stellen ervaring op te doen met de uitvoering van de betreffende leerpuntensequentie.

- therapeuten inzicht te geven in de mate warin de deelnemers de 1 eerpuntensequentie beheersen.

\subsubsection{Anticiperende gedragsoefening}

Vanaf de tweede groepsbijeenkomst wordt steeds meer aandacht besteed aan het inoefenen van door deelnemers zelf ingebrachte situaties. Dit ter bevordering van betrokkenheid, transfer l=overdracht van datgene wat men tijdens de groepsbijeenkomsten leert naar de elgen leefomgevingl en generalisatie. Anticiperende gedragsoefening vormt een van de manieren warop aan het inoefenen van door deelnemers zelf ingebrachte situaties vorm wordt gegeven. Anticiperend betekent dat deze oefeningen betrekking hebben op situaties, die nog moeten plaatswinden en 
war men bij voorbat tegenop ziet. Vanaf de tweede groepsbijeenkomst krijgen alle deelnemers tijdens elke zitting een beurt, wat deze vorm van gedragsoefening betreft. Alvorens een bepalde deelnemer de betreffende leerpuntensequentie op de door hemzelf ingebrachte situatie te laten toepassen, schakelen de therapeuten overige groepsleden als model in (zle ook paragraaf 3.2.1.2.). In overleg met de deelnemer wordt bepald hoeveel modellen wenselijk worden geacht en welke gedragselementen hij van de geobserveerde modellen wenst over te memen. Doel van deze anticiperende gedragsoefening is:

- de deelnemers voor te bereiden op de toepassing van de betreffende vaardigheid in eigen omgeving en wel op zodanige wijze dat de kans op effectieve afhandeling maximaal is.

- de deelnemers te motiveren de vaardigheid in eigen omgeving te gaan toepassen.

- de deelnemers in stat te stellen een eigen versie van de betreffende leerpuntensequentie te ontwikkelen.

- de deelnemers in staat te stellen ervaringen op te doen met de uitvoering van de betreffende leerpunten-sequentie.

De anticiperende gedragsoefeningen vinden of in monoloogvorm of in de vom van een dialoog plaats, "hardop denkend" in front van de groep. Is er sprake van oefeningem in monoloogvorm, dan zit de betreffende

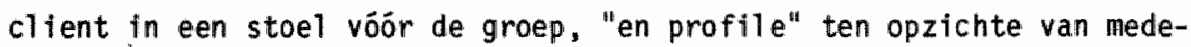
groepsleden, teneinde te voorkomen dat er onderlinge discussies ontstaan over de invulling van de leerpunten tijdens de oefeningen. Is er sprake van een dialoog, dan zitten therapeut en client op twee stoelen tegenover elkaar, weér in front van de groep. De dialoog werd als oefenvorm gekozen vanwege zijn mogelijkheden de client op soepele en natuurlijke wijze te kunnen ondersteunen bij het hardap onder woorden brengen van de betreffende denkstappen. Wat de vaardigheidstherapie "veranderingen aampakken" betreft, wordt de ondervragersrol in deze dialoog vanaf de 5 e zitting door een mede-groepslid overgenomen, nadat expliciete modeling van deze rol door de therapeuten heeft plaatsgevonden. Op deze wijze beoogt men de actieve beheersing van de leerpuntensequentie te bevorderen. 
Tijdens de oefeningen staat het bord met leerpunten zodanig opgesteld, dat dit goed leesbaar is voor alle deelnemers. Terwijl de ene therapeut de gedragsoefening leidt, makt de ander leerpuntsgewijs aantekeningen op de eveneens in front van de groep opgestelde flap-over. De therapeuten streven ernaar de deelnemers deze gedragsoefeningen zo zelfstandig mogelijk te laten doorlopen.

Er wordt in een zo hoog mogelijk tempo geoefend. Mede-groepsleden worden zonodig als model ingeschakeld. Bovendien worden ze door de therapeuten actief betrokken bij de vertaling van het getoonde gedrag in termen van de betreffende leerpuntensequentie.

\subsubsection{Reconstruerende gedragsoefening}

Reconstruerende gedragsoefening wordt toegepast wanneer er sprake is van faalervaringen bij de uitvoering van huiswerkopdrachten. De wijze waarop deze vorm van gedragsoefening wordt uitgevoerd, is gelijk aan die van de anticiperende gedragsoefening. Doel van deze vorn van gedragsoefening is het individu in stat te stellen een in het huiswerkverslag gerapporteerde faalervaring wat de toepassing van de leerpuntensequentie betreft, te reconstrueren en de betreffende siltuatie nogmaals te doorlopen tijdens de groepsbijeenkomst. Tijdens deze vorm van gedragsoefening krijgt de deelnemer een soort herkansing wat de toepassing van de leerpuntensequentie betreft.

Wit ervaring blijkt deze vorm van gedragsoefening ingewikkeld en tijdsintensief. Ingewikkeld omdat het vaak moeilijk is om met de client tot een bevredigende en betrouwbare reconstructie van de betreffende situatie te komen. Op grond van deze bevindingen werd dan ook besloten deze vorm van gedragsoefening zo min mogelijk toe te passen. De therapeuten dienen de huiswerkopdrachten voor de deelnemers zo te kiezen dat de kans op faalervaringen daarbij minimaal is. 


\subsubsection{Gedragsoefening in spelvorm}

Tijdens de vierde bijeenkomst van de vaardigheidstherapie "dagelijkse problemen aanpakken" vinden zogenaamde gedragsoefeningen "in spelvorm" plaats. Elke deelnemer krijgt een beurt wat deze worm van gedragsoefening betreft. De therapeuten brengen een door henzelf bedachte probleemsituatie in. Ze passen deze situatie zoveel mogelijk aan aan de betreffende deelnemer in die zin dat ze een situatie kiezen die aansluft aan diens alledagse leefsituatie en die in de lijn ligt van de sltuaties die tot dan toe door hemzelf werden ingebracht. Deze situatie wordt door therapeut en client in scene gezet met behuly $v_{\text {u. }}$ in de groepsruimte aanwezige attributen. De therapeut die de gedragsoefening leidt, vraagt medegroepsleden als antagonist(en) op te willen treden. Nadat de situatie voldoende is voorbereid, krijgt de deelnemer die de beurt heeft, de opdracht deze situatie te gaan spelen, waarbij vermeld wordt dat tijdens het uitspelen van deze situatie een probleem zal ontstaan. Wat dit probleem is, zal pas in de loop van het spel blijken. De protagonist krijgt als opdracht de betreffende leerpuntensequentie, hardop denkend, op dit probleem toe te passen. Dit hardop denken vindt plaats op een daartoe door de therapeut op het speelvlak neergelegd matje, ook well "denkmat" genoemd. Door op deze "denkmat" te stappen, geeft client aan de toeschouwers te kennen dat hij bezig is met het stellen van covert gedrag.

Doel van deze vorm van gedragsoefening is de deelnemers oefening te laten opdoen met het element van verrassing en overrompeling dat de meeste probleemsituaties in het dagelijks leven kenmerkt.

\subsubsection{Bekrachtiging}

In hoofdstuk 1 werd reeds aangegeven dat positieve (sociale) bekrachtiging een belangrijke plats inneemt in de door Goldstein ontwikkelde leermethode. Ook wat de Maastrichtse variant daarop betreft, geldt het bekrachtigingsprincipe als een centraal element bij het op gang brengen van de beoogde leerprocessen.

Het bekrachtigingsprincipe wordt op identieke wijze toegepast bij het 
aanleren van interpersoon 1 ijke en persoonlijke vaardigheden. Overeemkomstig de bron, kan men twee soorten bekrachtiging onderscheiden, te weten bekrachtiging door relevante anderen en zelfbekrachtiging. In het nu volgende zal worden beschreven op welke wijze elk van belide wordt geoperational iseerd tijdens de groepsbijeenkomsten.

\subsubsection{Bekrachtiging door relevante anderen}

Bekrachtiging door relevante anderen vindt plaats tijdens de groepsbijeenkomsten, in de eigen leefsituatie en in de individuele behande1 ingssituatie van waaruit de deelnemer voor deelname aan vaardigheidstherapieen werd verwezen. Deze bekrachtiging kan materieel danwel immaterieel van aard zijn. Voorbeelden van materiële bekrachtigers zijn sigaretten, een kop koffie.

Immateriële sociale bekrachtigers kunnen verbaal danwel non-verbaal worden toegediend. Voorbeelden van verbale sociale bekrachtigers zijn opmerkingen in de trant van "goed zo", "prima", "uitstekend".

Voorbeelden van non-verbale sociale bekrachtigers zijn een schouder$k 10 p$, een applaus in de groep, een duim op gebaar.

Ter optimalisering van het effect ervan, worden al deze bekrachtigers zo direkt mogelijk gekoppeld aan het stellen van het nieuw aan te leren gedrag door de betreffende persoon. De kwantiteit en/of kwaliteit van de bekrachtigers dient zoveel mogelijk te worden afgestemd op de door het individu geleverde prestaties rekening houdend met diens actuele vaardigheidsniveau, leermogelijkheden en geleverde inspanning. Aanvankelijk vindt sociale bekrachtiging alleen plats door de therapeuten; in de loop van de bijeenkomsten gaan successievelijk medegroepsleden, personen in de thuisomgeving en - na beëindiging van de groepsbijeenkomsten - ook de hoofdbehandelaar c.q. verwijzer deze bekrachtigende functie overnemen.

Personen wit de eigen leefomgeving worden in dit opzicht niet expliciet ingeschakeld door de vaardigheidstherapeuten maar worden geacht vanzelf als natuurlijke bekrachtigers te fungeren. Het begrip natuurlijk verwijst naar de veronderstelling dat posfitieve sociale bekrachtiging een normaal onderdeel vormt van het dagel ijks functioneren. 
Hoofdbehandellars c.q. verwijzers worden verzocht de toepassing van de betreffende leerpuntensequentie positief te blijven bekrachtigen en stimuleren ook nadat de groepsbijeenkomsten zijun afgelopen.

In de loop van de tijd streeft men ernaar dat het stellen van de wardigheild steeds meer intrinsiek bepaald wordt en dat extrinsteke vormen van bekrachtiging dardoor geleidelijk aan overbodig worden.

\subsubsection{Zelfbekrachtiging}

Tijdens de bijeenkomsten leggen de therapeuten aan de deelnemers uit dat zelfbekrachtiging een belangrijke rol kan spelen bij het aanleren van vaardigheden. Men leert de deelmemers zichzelf te belonen woor het adequat stellen van het betreffende doelgedrag. Het onderscheid materieel versus immaterieel is ook hier van toepassing. Voorbeelden van materiele wormen van zelfbeloning zijn het zichzelf trakteren op een kop koffle of gebak in een lumchroom, gaan winkelen, naar de bioscoop gaam, een etentje buitenshuis, een bos bioemen of een extra tijdschrift. Voorbeelden van immateriele zelfbeloning zijn coverte zelfuitspraken in de trant van "prima", "goed zo", "O.K.".

De zelfbeioningen dienen zodanig gekozen te worden, dat deze een vervulling vormen van elgen interessen, wensen, behoeften en verlangens. De door henzelf vastgestelde vormen wan zelfbeloning worden door de clienten in hun huiswerkboekjes genoteerd (zje 3.2.4.2.).

Ook hier geldt dat men er in de loop van de tijd naar streeft dat het stellen van de betreffende vaardigheid steeds meer intrinsiek bepaald wordt en dat extrinsieke vomen van bekrachtiging geleidelijk aan overbodig worden.

\subsubsection{Transfertraining}

Ter bevordering van de overdracht van datgene wat clienten tijdens de groepsbljeenkomsten leren naar de eigen leefsituatie, worden tijdens de persoonlijke en interpersoonlijke vaardigheidstherapieën, nast de in 3.2.3.2. genoende afspraken omtrent zelfbekrachtiging de nu vol- 
gende matregelen genomen:

- er worden huíswerkopdrachten gegeven

- er wordt gebruik gemaakt van huiswerkboekjes

- er worden "herinneringssignalen" afgesproken

\subsubsection{Huiswerkopdrachten}

Tijidens de groepsbijeenkomsten geven de therapeuten hui swerkopidrachten mee aan de deelnemers. Deze huiswerkopdrachten betreffen de witwoering van de nieuw aan te leren vaardigheid in de eligen leefsituatie. Deze opdrachten kumnen betrekking hebben op de betreffende vaardigheid in haar totaliteit of op de uitvoering van bepaalde onderdelen daarvan. Tijjdens de eerste ziltting wordt het beliang van het daadwerkelijk uitvoeren van deze opdrachten benadrukt. De therapeuten geven aan dat de ervaringen met de huiswerkopdrachten steeds het centrale oefenmateriaal zullen vormen voor de eerstvolgende groepsbijeenkomst. Het huiswerk voor de periode tussen de eerste en tweede groepsbijeenkamst is standaard. Het bestaat uit de volgende opdrachten:

a. let op hoe anderen in uw omgeving deze vaardigheid uitwoeren en ga na wat daambij opvalt met het oog op de besproken leerpuntensequentife.

b. pas de eerste twee (soms de eerste drie) leerpunten van deze vaardigheid toe in uw eigen situatie. lof men twee of drie leerpuntem opgeeft, is afhankelijk van het vaardigheidsniveau van de betreffende deel nemers).

Vanaf de tweede groepsbijeenkomst start men steeds met de bespreking van de huiswerkervaringen. Daadwerkelijke witvoering van de opgegeven huiswerkopdrachten wordt door de therapeuten expliclet bekrachtigd. Ten opzichte van deelnemers die het huiswerk niet hebben uitgevaerd, lat men duidelijk teleurstelling blijken: kort maar krachtig. Therapeuten geven in zo' $n$ geval nogmaals aan dat de uitvoering van het afgesproken huiswerk onmisbaar is bij het aanleren van de vaardigheid. Faalervaringen met huiswerkopdrachten worden op de flap-over genoteerd. Deze faalervaringen worden, na beëindigling van de hul swerkbe- 
spreking, teniet gedaan $c . q$. gecorrigeerd met behulp van een reconstruerende gedragsoefening.

Vanaf de tweede zitting windt het opgeven van huiswerk direct na de beëindiging wan de anticiperende gedragsoefening plaats. De huiswerkopdrachten zijn dan niet meer voor ledere deelnemer gelijk maar worden individueel opgegeven, afgestemo op het prestatieniveau en de leemogelijkheden van het betreffende individu. Ter optimalisering van de motivatie van het individu an de opgegeven opdrachten ook uit te voeren, worden de gemakte afspraken op de flap-over genoteerd. Per huiswerkopdracht wordt steeds genoteerd wàt de betreffende cllent gaat doen (hoeveel leerpunten en welke precies), wàr (op welke plaatsen), wänneer lop welke dag, tijd, plaats). Tijdens de laatste zitting wordt een soort onderhoudsdosis huiswerk bepaald. Ook wordt met de deelnemers nagegaan hoe zij de nieluw aangeleerde vaardigheid kunnen blijven toepassen zonder de hulp c.q. bekrachtiging van medegroepsieden en therapeuten.

\subsubsection{Huiswerkboekjes}

Voor elk van de ontworpen vaardigheidstherapleën werd een bijpassend huiswerkboekje ontwikkeld. Dit als hulpmiddel voor de deelnemers bij de toepassing van de leerpunten en de uitvoering van de huiswerkopdrachten in de periade tussen de groepsbijeenkomsten. De clienten noteren daarin waar en wanneer ze welke leerpunten gaan toepassen, en (eventuee 1) met wie. Ook is er ruimte vrijgemaakt voor het opschrijven van ervaringen, opgedaan bij de uitvoering van de huiswerkopdrachten. Het huiswerkboekje wordt door de clienten beheerd en blijft hun eigendom. Net als bij een dagboek is het aan hen of zij daaruit iets openbaar willen maken en zo ja, wat dan. Dit geldt ook ten opzichte van de therapeuten. Clienten die niet kunnen schrijven, worden door de therapeuten op onopwallende wijze geholpen bij het opschrijuen van hun opdrachten. Bij de huilswerkbesprekingen tijdens de groepsbijeenkomsten dienen deze boekjes als persoonlijke geheugensteun voor de clienten. De therapeuten zien erop toe dat de boekjes daadwerkelijk worden gebruikt, ze controleren echter niet hoe de betreffende client zijn notities maakt. 
Ter bevordering van de continuiteit in het stellen van de nfeuw aangeleerde vaardigheid, wordt tijdens de laatste groepsbijeenkomst in overleg met elk van de deelnemers afzonderlijk een "herinneringssignaal" vastgesteld. Een "herinneringssignaal" is een door de deelnemer zelf gekozen voorwerp dat hem in sterke mate herinnert aan datgene wat hij tijdens de groepsbijeenkomsten leerde alsook aan de voornemens die hij daar maakte met betrekking tot het blijven stellen van de betreffende vaardigheid, ook nadat de groepsbijeenkomsten zijn afgelopen. Men kan in dit opzicht gebruik maken van stickers, ansichtkaarten, een beeld met een symbolische waarde etc. Ook het huiswerkboekje kan als "herinneringssignaal" fungeren. Met de deelnemers wordt afgesproken dat $z i j$ dit signaal een zodanige plats geven, dat ze het regelmatig bewust waarnemen.

\subsection{INDICATIES VDOR DEELNAME}

Nadat in 3.2. werd beschreven op welke wijzen de basiscomponenten uit Goldstein's methode worden geoperationaliseerd tijdens de witvoering van de persoonlijke vaardigheidstherapieën, zal hierna nader worden ingegaan op de indicaties voor deelname op vaardigheidsniveau. De vaardigheidstherapieën à la Goldstein zijn ontwikkeld voor geeste$1 \mathrm{ijke}$ gezondheidszorg $\mathrm{clienten}$ uit de lagere sociaal-economische $\mathrm{klas-}$ sen; ook wel aangeduid als LIBO-clienten. Deelname aan persoonlijke vaardigheidstherapieën is aangewezen voor LIBO-clienten, bij wie er sprake is van evidente vaardigheidstekorten ten aanzien van een of meerdere van de in dit proefschrift beschreven persoonlijke vaardigheden, te weten "dagelijkse problemen aanpakken", "beslissingen nemen", "informatie verzamelen" en "veranderingen aanpakken". Dergel ijke vaardigheidstekorten zijm te onderkennen door nadere inspectie van de recente levensloop van de betreffende individuen. Het gaat uiteraard niet om een als normal te beschouwen incidenteel tekort maar om een tekort dat met een zekere regelmat blijkt terug te keren. Dergelijke tekorten worden veelal manifest maar aanleiding van veranderingen van 
levensomstandigheden die het gevolg kunnen zijn van onder andere het verlies van partner en/of werk, het uit huis gaan van opgroeiende kinderen, de beëindiging van een langdurig verblijif in een (psychiatrische) klinjek of ook de beëlndiging wan een langerdurende periode van vermijdingsgedrag ten gevolge van psychische stoornissen. Derge11jke omstandigheden hebben vaak tot gevolg dat het gebruikelijke coping-repertoire niet langer afdoende is. Daarbij wordt in het midden gelaten of:

a. het niet beheersen van de vaardigheid (een onderdeel van) hẽt centrale probleem van de client vormt;

b. het beheersen van de vaardigheld een noodzakelijke voorwaarde vormt voor de uitvoering van het door de hulpverlener ten aanzien van deze cl ient opgestelde behandelingsplan;

$c$. het niet beheersen van de vaardigheid het centrale probleem van de client (mede) in stand houdt;

d. men verwachten kan dat deze clienten, wanneer zij de betreffende vaardigheid voldoende beheersen, beter in staat zullen zijn probleemsituaties het hoofd te bieden of te voorkomen.

A $t / m d$ werden eerder beschreven in Beekers (1982). Clienten worden voor deelname aan persoonlijke vaardigheidstherapieën in aanmerking genomen wanneer doorverwijzende individuele hulpverlener en client zelf van oordeel zijn dat de client de betreffende vaardigheid(heden) onvoldoende beheerst.

De indicatie voor deelname wordt gesteld door de verwijzende hulpverlener op basis van bovenstaande informatie. Er zijn vooralsnog geen gestandaardiseerde schriftelijke vragenlijsten beschikbaar die bij de indicatie-stelling behulpzaam kumnen zijn.

Gezien het feit dat er sprake is van vier verschillende persoonilijke vaardighefdstherapleën, besloot de Goldsteinprojectgroep ten behoeve van de overzichtelijkheid voor potentfële verwijzers het type client per vaardigheid als volgt te specifficeren. 
De vaardigheidstherapie "dagelijkse problemen aanpakken" is erop gericht deelnemers effectiever te leren omgaan met - al of niet verwachte - voorvallen, die de dagelljkse gang van zaken verstoren en waarvoor het betreffende individu niet onmiddellijk een effectief respons-alternatief voor handen heeft. Wat deze vardigheidstherapie betreft, is er dus primair sprake van een "reageer"-vaardigheid. Het toepassen van de leerpuntensequentie is een alternatief voor en bovendien incompatibel met een inadequate (emotionele) reactie. Deelname aan deze vaardigheidstherapie is geindiceerd voor clienten die aan eên of meer van de volgende voorwaarden voldoen:

- in voor hen problematische situaties paniek-reacties vertonen met alle gedragsinhiberende gevolgen vandien.

- in voor hen problematische situaties slechts éen reactiewijze als. oplassing zien of ter beschikking hebben, warbij bovendien soms geldt dat men zichzelf niet in staat acht deze oplossing in praktijk. te brengen.

- in voor hen problematische situaties afwachtend en apathisch reageren.

\subsection{2. "Veranderingen aanpakken"}

De vaardigheidstherapie "veranderingen aanpakken" beoogt cliemten te leren door henzelf gewenste veranderingen daadwerkelijk tot stand te brengen.

De vaardigheidstherapie "veranderingen aanpakken" is geindiceerd voor clienten die aan éen of meer van de volgende voorwaarden voldoen:

- zichzelf voortdurend voor onmogelijke opgaven stellen,

- wel globaal jets willen maar daarbij niet tot concrete plannen en/of activiteiten komen,

- impulsief aan veranderingen beginnen, maar die niet afmaken,

- wel pllannen maken on dingen te veranderen maar daar verder niets mee doen,

- snel opgeven bij tegenslag. 
De gewenste verandering kan zowel betrekking hebben op het functioneren van de persoon zelf als op nader omschreven aspecten wan zijn levensomstaind igheden.

\subsection{3. "Beslissingen nemen"}

De vaardigheidstheraple "beslissingen nemen" is geindiceerd voor clienten die:

- të overhaast tot besluitworming overgaan zonder stil te staan bij de magelijke gevolgen op korte of langere termijn voor de persoon zelf en voor zijin omgeving;

- geconfronteerd met een welomschreven keuze niet tot een zelfstandige beslissing kunnen komen en het nemen van de beslissing zolang uitstellen totdat anderen of "de tijd" deze belissing voor hen nemen.

Deelname aan deze vaardigheidstheraple is aangewezen wanneer een client aan ëén of meer van bovengenoende voorwaarden voldoet.

\subsection{4. "Informatfe verzamelen"}

De vaardigheidstherapie "informatie verzamelen" is geindiceerd voor clienten die niet in staat blijken:

- na te gaan op welke wijzen ze door hen benodigde informatie(s) kunnen verzamelen;

- een concreet plan te maken voor de wijze warop ze deze informatife(s) wensen te verwerven;

- de door hen ingewonnen informatie(s) te ordenen, samen te vatten en te evalueren.

Deel name is aangewezen wanneer een client aan één of meer van bovengenoemde voorwaarden voldoet. 
Nadat in 3.3. uitgebreid werd ingegaan op de door de Goldsteinprojectgroep vastgestelde indicaties voor deelname aan persoonl ijke vardigheidstherapieën, worden in 3.4. een aantal algemene richtlijnen voor therapeuten behandeld, die bij de uitwoering van de persoonlijke vaardigheidstherapieën van belang ziljn.

Elke persoonlijke vaardigheidstherapie wordt begeleid door twee therapeuten. Eên van beide heeft de "regie" over de gedragsoefening en heeft al zijn aandacht nodig voor datgene wat zich op het speelvlak afspeelt. De tweede therapeut kan tijdelijk als model of als antagonist worden ingeschakeld. Bij voorkeur is hij echter bij de groep waar hij waakt over de toeschouwende clienten en model-gedrag vertoont met betrekking tot bekrachtiging-door-toeschouwers. Voor zover nodig, maakt hij met viltstift aantekeningen op de flap-over. Beide therapeuten hebben dezelfde taak, waarbij ze afwilsselend de regie op zich nemen. Ze treden structurerend, directief en duidelijk leiding memend op. Vragen worden direct gesteld aan met name genoemde individuën en nooit aan de groep in het algemeen. Elke bijeenkomst worden de deelnemers, ieder afzonderlijk, in de gelegenheid gesteld de betreffende vaardigheid in te oefenen in de door hen als veilig ervaren groepssituatie. De therapeuten dienen de beschikbare tijd evenredig over het totaal aantal deelnemers te verdelen. Clienten die de neiging hebben breedsprakig te zijn, worden tijdig afgestopt en bijgestuurd onder verwijzing naar de betreffende leerpuntensequentie. Actieve deelname van groepsleden wordt zoveel mogelijk bevorderd en gestimuleerd door de therapeuten. Dit kan gebeuren door de deelnemers in een model-functie ten opzichte van elkaar in te schakelen maar ook door hen te vragen thet door hun mede-groepslid(leden) gestelde gedrag in termen van de leerpunten te vertalen. Tempo en directiviteit komen het leerproces ten goede doordat ze mogelijk aanwezige spanningen reduceren en de attentile en betrokkenheid van de deelnemers bfj het therapie-programma bevorderen.

Tijdens de groepsbijeenkomsten wordt geen expliciete aandacht besteed aan groepsdynamische processen en aspecten. Interactles tussen deelnemers onderling worden vrijwel steeds uitgelokt en voorgestructureerd 
door de therapeuten. Ook al worden interacties tussen deelnemers onderling niet nader geanalyseerd en/of geëxpliclteerd in groepsdynamische termen, toch blijken groepsfenomenen in de zin van universaliteit van schijnbaar private problematiek door middel van "sharing" een rol te spelen. Deze "sharing" heeft volgens Yalom (1975) universalisering van individuele problematiek tot gevolg. Wat de hier beschreven vaardigheidstherapieën betreft, geldt dat sharingprocessen tot gevolg hebben dat de deelnemers feder voor $z$ ich de eigen $k 1$ achten en problemen gaan relativeren waardoor opluchting ontstaat. De onderlinge herkenning heeft bovendien tot gevolg dat de motivatie om aan de oplossing van de geconstateerde vaardigheidstekorten te werken, versterkt wordt.

3.5. DE RELATIE TUSSEN PERSOONLIJKE EN INTERPERSOONLIJKE VAARDIGHEIDSTEKORTEN

Ten aanzien van zowel "dagelijke problemen aanpakken" als "veranderingen aanpakken" geldt dat in de leerpunten-sequentie een of meerdere leerpunten zijn opgenomen, die de aanwezigheid van basale interpersoonijke vaardigheden veronderstellen. Voor beide vaardigheden geldt dat het laatste leerpunt betrekking heeft op de daadwerkelijke uitvoering van de uitgedachte strategie c.q. aanpak (zie ook 2.3.1. en 2.3.2.). Bij deze uitvoering spelen vrijwel altijd ook interpersoon1 ijke situaties een rol. Adequate afhandeling van deze situaties vereist de aanwezigheid van basale interpersoonlijke vaardigheden in het copingrepertoire van het betreffende individu. Wanneer deze vaardigheden wel in het copingrepertoire aanwezig zijn maar door omstandigheden enigszins in onbruik geraakt, kan het noodzakelijk zijn deze vaardigheden op te frissen door middel van een anticiperende gedragsoefening. Is er echter sprake van aperte tekorten in interpersoonlijk gedrag, en heeft een dergelijke opfrisoefening onvoldoende effect, dan is deelname aan een of meerdere interpersoonlijke vaardigheidstherapleën geïndiceerd. Omgekeerd geldt eveneens dat tijdens deelname aan interpersoonlijke vaardigheidstherapieën persoonlijke vaardigheidstekorten kunnen worden geconstateerd bij de deelnemers die deelname 
aan een of meerdere persoonlfjke vardigheidstherapleën noodzakelijk maken.

Is er sprake van aperte vaardigheidstekorten wat betreft de directe regulering van paniek, angst en spanning, dan vormt training in pal1 iatieve - op directe regulatie van emotiels) gerichte - vaardigheden een noodzakelijke voorwaarde vooraf aan deelname aan persoonlijke waardigheidstherapieën.

\section{6. "IMPLICIETE" LEERPUNTEN}

Bij de persoonlijke vaardigheidstherapieën worden naast de expliciet omschreven leerpuntensequenties nog een aantal - meer impliciete aandachtspunten behandeld, die de algemene attitude van het individu ten aanziem van de vaardigheid betreffen. Hoewel min of meer logisch en vanzelfsprekend voortvloeiend üt de eigen aard van de vaardigheid, bleek het toch noodzakelijk dat de therapeuten tijdens de groepsbijeenkomsten expliciet aandacht besteedden aan deze attitude-aspecten. Voor een overzicht van de impliciete leerpunten "dagelijkse problemen aanpakken" zie bijlage I; voor "veranderingen aanpakken" idem bijlage II.

\subsection{PROTOCOLLEN WOOR THERAPEUTEN}

Voor elk van de vier persoonlijke vaardigheidstherapieën werden protocollen ontwikkeld voor therapeuten als richtlijn bij de uitvoering daarvan. In bijlage 1 wordt het protocol woor de vaardigheidstherapie "dagelijkse problenten aanpakken" beschreven. In bijlage II voor "veranderingen aanpakken". De protocollen voor de vaardigheidstherapleën "informatie verzamelen" en "beslissingen nemen" zijn op dezelfide wijze opgebouwd als het protocol voor de vaardigheidstheraple "dagel ijkse problemen aanpakken". 
HOOFDSTUK 4. PLAATS VAN DE PERSOONLIJKE VAARDIGHEIDSTHERAPIEEN A LA GOLDSTEIN IN HET TOTALE VELO VAN DE COGNITIEVE GEDRAGSTHERAP IE

\subsection{INLEIDING}

De in hoofdstuk 2 beschreven persoon $7 j$ jke vaardigheidstherapieën maken deel wit van de cognitieve gedragstherapie. De term cognitieve gedragstherapie verwijst naar de totale verzameling cognitief georienteerde psychotherapeutische interventies, gebaseerd op leertheoretische principes en uitgangspunten. In het nu volgende zal worden nagegaan:

- waar de term cognitieve gedragstherapie feitelijk naar verwijst (paragraaf 4.2.).

- op welke wijze men enige ordening zou kunnen aanbrengen op het terrein van de cognitieve gedragstherapie (paragraaf 4.3. ).

- wat de plaats is van de persoonlijke vaardigheidstherapieën à la Goldstein binnen dit geheel (paragraaf 4.4.).

- wat de knelpunten zijn in de cognitieve ontwikkeling in de gedragstherapie (paragraaf 4.5.).

4.2. BEKNOPTE INHOUDELIJKE TYPERING VAN DE COGNITIEVE GEDRAGSTHERAPIE

In zijn onderzoek naar huidige trends in psychotherapie en counseling concludeert Smith (1982) dat: "cognitive-behavioral options represent one of the strongest if not the strongest theoretical emphases today" (p.808). Wat de gedragstherapie betreft, kan men constateren dat de ontwikkeling van cognitieve interventies de laatste jaren een grote v1ucht heeft genomen.

Het werk van Beck en Ellis uit het begin van de zestiger jaren vormde de basis voor de opkomst van de cognitieve gedragstherapie. Op basis van $k l$ inische ervaringen kwamen deze auteurs, beiden psychoanalytici van oorsprong, tot het inzlcht dat cognities een belangrijke rol 
spelen bij het ontstaan van psychische problemen. Beck $(1964,1967$, 1976) ontwierp een cognitieve therapie ter behandeling van depressieve patienten. Ellis $(1962,1970)$ ontwikkelde in de loop van de tijd de "Rational Emotive Therapy" ook wel bekend als de RET. Beide auteurs bekommerden zich nauwelijks on de theoretische onderbouwing van de door hen ontwikkelde methodes; de $k l$ inische bruikbaarheid ervan vormde hun belangrijkste interessegebied.

In de zeventiger jaren kan men een internationale doorbraak constateren wat de invoering van cognitief georiënteerde psychotherapeutische interventies betreft.

Van Quekelberghe (1979) omschrijft de cognitieve gedragstherapie als een bonte verzameling van therapeutische technieken en modellen die allen iets met cognities te maken hebben. De cognitieve gedragstherapie wordt ook wel aangeduid als cognitieve therapie of als "cognitivebehavioral interventions". Deze laatste benaming geeft aan dat er wat deze interventies betreft, meestal sprake is van een combinatie van zowel cognitief als gedragsgerichte interventies. De tot nu toe ontwikkelde cognitief gedragstherapeutische interventies verkeren merendeels nog in een experimentee 1 stadium.

De cognitief gedragstherapeutische interventies werden dus ontwikkeld door clinici als antwoord op praktijkproblemen. Er was geen sprake van een duidelijke theoretische grondslag.

Sinds de vijftïger jaren kan men ook in de theorievorming een groeiende aandacht voor cognitieve aspecten en factoren onderscheiden. Tot nu toe werden echter nog weinig pogingen gedaan deze algemene theoretische ontwikkelingen te vertalen in concrete (psycho)therapeutische interventies. Wel kan men constateren dat in de cognitieve gedragstheraple steeds vaker geprobeerd wordt de - veelal op praktische ervaringen met clienten gebaseerde - cognitieve gedragstherapeutische interventies in te passen in bestaande cognitieve verklaringsmodellen. Uit bovenstaand blijkt dat er nog steeds sprake is van een behoorlijke kloof tussen de algemene psychologische theorievorming en de psychotherapeutische praktijk. Beide ontwikkelen zich los van elkaar.

Het merendeel van de cognitief gedragstherapeutische interventies stelt zich ten doel de mogelijkheden tot zelfcontrale bij het individu te vergroten. De geleidelijke invoering van het aanleren van meer 
zelfcontrole aan clifenten betekende een belangrijke ommekeer in de gedragstherapie. Het individu wordt zodoende in steeds mindere mate als een willoos object van zijn omgeving opgevat maar als een subject dat zijn omgeving waarneemt, interpreteert en tot op zekere hoogte ook kan veranderen. Het object van de gedragstherapie wordt daarmee meer subject. Therapeutische interventfes veranderen van, overwegend door anderen gestuurde, vormen van manipulatie in het aanreiken van hulpmiddeien aan het individu die hij zelfstandig kan toepassen met als doel een grotere mate van zelfcontrale te verwerven (Schulte, 1977). Afziend van de grote diversiteit in accent en procedures onderscheiden Mahomey en Arnkoff (1978) 3 vooronderstellingen die in alle cognitieve therapieën op leertheoretische basis gehanteerd worden:

1. mensen leren aangepast en onaangepast gedrag en emoties aan door middel van cognitieve processen (selectieve aandacht, symbolische codering etc.)

2. deze cognitieve processen kunnen functioneel geactiveerd worden door procedures die overeen komen met de procedures uit de experimentele leerpsychologie

3. de cognitieve gedragstherapeut heeft tot taak deze cognitieve processen op te sporen en te veranderen door middel van door hem speciaal ten behoeve van deze client/patient ontworpen correctieve leerervaringen.

Men gaat er in de cognitieve gedragstherapie van uit dat elke situatie cognitief verwerkt wordt door het individu en dat deze verwerking daaropvolgend gedrag en/of emotie bepaalt. Cognitief gerichte interventies worden gekenmerkt door het feit dat verandering van cognities en/of gedachten als ingang dient om verandering in gedrag en/of emotie tot stand te brengen.

\subsection{DE COGNITIEVE GEDRAGSTHERAPIE INGEDEELD IN 3 CATEGORIEEN}

Wat het totale veld van de cognitieve gedragstherapie betreft, blijkt er sprake van een grote diversiteit aan interventies. In nawolging van Mahoney en Arnkoff (1978) en Eelen (1982b) kan men het totale veld van 
de cognitieve gedragstherapie indelen in drie categorieën, the weten:

- de cognitieve herstructurering

- de coping-ski11s-therapieën

- de problem-solving-therapieën

In de nu volgende paragraffen zullen deze drie categorieèn elk afzonderi iljk worden beschreven.

\subsubsection{Cognitieve herstructurering}

De gedragstherapeutische methodieken gericht op cognitieve herstructurering gaan uit van de vooronderstelling dat foutieve denkprocessen de basis vormen voor gedragsproblemen en onaangepaste emoties. Cognitieve herstruktering heeft als doel dergelijke denkprocessen op te sporen en te veranderen. Binnen het domein van de cognitieve herstructurering zijn twee scholen te onderscheiden:

a. de rationele therapie ontwikkeld door Albert Ellis (1962).

Aanhangers van deze school gaan, in navolging van Ellis, uft van de vooronderstelling dat irrationele denkinhouden de voornaamste oorzaak vormen van emotionele problemen, Niet de werkelijkheid zelf maar veeleer de opvattingen van het individu over deze werkelijkheid doen emotionele problemen ontstaan. Opvattingen van het individu over de werkelijkheid die aanleiding geven tot het ontstaan van emotionele problemen zijn volgens E1lis veelal irrationeel van aard. De RET streeft ernaar de client(en) te leren deze opvattingen - ook wel irrationele ideeën genoemd - rationeel te ontleden met behulp van een zogenaamd $A B C$-schema. In dit $A B C$-schema verwijst $A$ naar een beschrijving van de betreffende situatile in objectieve termen; B naar een beschrijuing van de - meestal irrationele - opvattingen van het individu met betrekking tot deze situatie en $c$ verwijst naar de emotionele reactie van het individu in de betreffende situatie. In de rationele theraple leert men irrationele gedachten bij zichzelf opsparen en corrigeren. Diekstra (1979) ontwierp een gemodificeerde versie van deze methodiek. 
b. de cognitieve therapie ontwikkeld door Beck.

Beck (1970, 1976) werd getroffen door de rol die irrationele gedachten en fantasieën leken te spelen bij het tot stand komen van depressies. Op basis van $k$ linisch onderzoek stelde hij vijf irrationele denkpatronen vast die hij verantwoordelijk acht voor het tot stand komen van depressies. Deze patronen zijn:

- de tendens tot personalisatie, dat wil zeggen de neiging om de oorzaak van al wat gebeurt aan zichzelf toe te schrijven, met name wat negatieve gebeurtenissen betreft.

- denken in extremen, met andere woorden denken in termen van goedfout, juist-onjuist, schuldig-onschuldig, etc.

- selectleve abstractie waardoor men detalls wit hun context halt en teveel gewicht toekent.

- algemene conclustes trekken uit willekeurige gegevens.

- overgeneralisatie, inhoudend dat men algemene conclusies trekt op basis van éën enkel voorval.

Beck is van mening dat deze - min of meer pathologische - irrationele denkpatronen verankerd liggen in de vaste schema's waarmee het individu zichzelf, zijn omgeving en de toekomst interpreteert en benadert. Dit drievoudige object van cognities staat bekend als de zgn. cognitieve triade van Beck.

De rationele therapie is erop gericht de client zijn foutieve denkstij1(en) te doen inzien en deze vervolgens te wijzigen door middel van een reeks opdrachten c.q. gedragsopgaven die in de therapiezittingen worden ingeoefend en in de thuissituatie als "huiswerk" moeten worden uitgevoerd. De client leert zelfstandig materiaal te verzamelen dat zijn - veelal foutieve - denkstijl ter discussie stelt. De therapiegesprekken hebben de vorm van een socratische dialoog, dit in tegenstelling tot de confronterende debatten zoals E11 is die in de RET voert. Conform zijn oorsprong wordt de rationele therapie à la Beck voornamelijk toegepast bij depressieve patienten (Beck 1970, 1976; Beck, Rush, Shaw, Emery 1979).

De hierboven beschreven vormen van cognitifeve herstructurering vertonen duidelijke accentverschillen wat het focus van interventie betreft. Beide scholen hebben met elkaar gemeen dat zij zich ten doel 
stellen het individu een meer rationele manier wan demken aan te leren met het nodige relativisme, scepsis en humor. De doar Ellis ingenomen standpunten met betrekking tot rationaliteit en irrationaliteit maken over het geheel genomen een sterk dogmatische indruk. Het relativiteltsprincipe 11 jkt zadoende slechts eenzijdig van toepassing en wel op de client. Diekstra's RET vertoont in dit opzicht meer overeenkonst met Beck's cognitieve therapie dan met de door Ellis ontwikkelde RET. Het rationaliteitsprincipe wordt door Diekstra minder dogmatisch toegepast dan door Ellis. Tijdens de therapie gaat Beck minder confronterend te werk dan Ellis.

Zowel Ellis als Beck streven ernaar individuen op andere wijze met denkinhouden te leren ongaan. Beiden gaan uit van de vooronderstelling dat veranderingen in denkprocessen aanleiding zullen geven tot verandering van gedrag en emoties.

\subsubsection{Coping-skills-therapieën}

De caping-skills-therapieën omvatten een verzameling uiteenlopende interventies gericht op het aanleren van vaardigheden die de client in staat stellen adequater om te gaan met situaties die een grote mate van spanning bij hem oproepen.

Het door Lazarus (1966) ontworpen stressmodel vormt het uitgangspunt voor deze benadering. De coping-skills-therapieën onvatten oefeningen in het toepassen van doelgerichte zelfinstructie, ontspanningstechnieken, aandachtsafleidingstechnieken, als sook het inoefenen van gedrag. Nadruk wordt gelegd op het versterken van de palliatieve copingfuncties - d.w.z. het adequater reguieren van emoties - teneinde instrumentele vormen van coping, gericht op het direct aampakken en veranderen van de betreffende situatie, mogelijk te maken.

Het gros van de programma's omvat oefening(en) zowel in palliatieve als in instrumentele copingvaardigheden.

Men kan binnen deze categorie de volgende varianten anderscheiden:

a. de zelf-instructie-trainingen van Meichenbaum (1974, 1977),

b. de "covert-modeling" van Cautela (1971),

c. de door Goldfried (1971) ontworpen systematische desensftisatieprocedure, 
d. de "anxiety-management-trainingen" a la Suinn en Richardson (1971),

e. de "stressinnoculatie-trainingen" zoals onder andere ontwikikeld door Meichenbaum (1971).

Voor een madere beschrijuing van elk van deze subvormen afzonderlijk gel ieve men de daartoe aangegeven 11 teratuurbronnen te raadplegen.

De besproken coping-skilis-therapieën hebben met elkaar gemeen dat men de deelnemers daaraan traint in een aantal verschillende manieren waarop men met opkomende spanning(en) kan omgaan. De aangeteerde strategieën zijn algemeen toepasbaar en niet gefocussed op specifieke stimuli c.q. typische probleeminhouden. De nadruk ligt op het tot stand brengen van een grotere mate van zelfcontrole.

De coping-skills-therapieën zijn allen gericht op het leren reguleren van emoties die een adequate en doelgerichte taakuitwoering in de weg staan. Deze emoties hebben veelal de vorm van angst of agressie. De in dit verband nagestreefde doelen geven blijk van een zekere eenzijdigheid. Nadere inspectie van een aantal tot deze benadering te rekenen programma's (o.a. Novaco, 1975; Meichenbaum, 1977) leidt tot de conclusie dat over het algemeen gestreefd wordt naar rationalisatie en beheersing wat dit soort gevoelens betreft.

\subsubsection{Problem-solving-therapieën}

In het nu volgende worden de problem-solving-therapieën beschreven. Er zal achtereenvolgens aandacht worden besteed aan historische ontwikkeling, doelstelling en werkwijze.

D'Zurilla en Goldfried deden in 1971 als eersten een poging voorgestructureerde en systematisch onschreven probleemoplossingsstrategieën te gaan toepassen bij de behandeling van psychiatrische problematiek. Deze auteurs gaan ervan uit dat het aanleren van een voorgestructureerde probleemoplossingsstrategie aan psychiatrische patienten relevant is vanwege de huns inziens zeer uitgebreide generalisatie-moge11Jkheden. D'Zurilla en Goldfried gaan uit van de veronderstelling dat abnormaal gedrag en/of emotionele stoornissen opgevat kunnen worden 
als vormen casu quo gevolgen van ineffectief gedrag. Wanneer het individu niet in staat is bepaalde (situationele) problemen adequat op te lossen geeft dat volgens hen aanleiding tot ongewenste effecten in de vorm van angsten, depressies, etc. Spivack c.s. (1976) werkten deze benadering verder wit. Ze ontdekten dat er een verschil bestaat in probleemoplossend vermogen en probleemoplossingsvaardigheden tussen normale en gedragsdeviante populaties en dat training in probleem oplossen bij een aantal deviante populaties tot positieve resultaten leidde. (Platt, Scura en Hannon, 1973; Platt en Spivack, 1972a, 1972b, 1973, 1974; Shure en Spivack, 1972; Shure, Spivack en Jaeger; 1971; Siegel en Spivack, 1976 Spivack en Shure, 1974; Spivack, Platt en Shure, 1976). Tal van auteurs gingen daarna op deze zelfde onderzoekslijn verder: leertheoretici zowel als systeemgeorienteerde auteurs (0.a. Haley C.5. 1976). Probleemoplossingsstrategieën werden toegepast zowel met betrekking tot individuele problemen als ook met betrekking tot huwelijks-, relatie- en gezinsproblematiek. De tot nu toe bereikte resultaten wekken positieve verwachtingen met betrekking tot verdere ontwikkelingen in deze richting (Mahoney en Arnkoff, 1978).

Problem-solving-therapieën worden bij uiteenlopende problemen en klachten toegepast. Deze therapieën zijn primair gericht op het versterken van de instrumentele copingfuncties van de deelnemers. Tijdens deze therapieën wordt nauwelijks aandacht besteed aan het aanleren en versterken van palliatieve copingwijzen.

4.4. DE PERSOONLIJKE VAARDIGHEIDSTHERAPIEEN A LA GOLDSTEIN ALS EEN VORM VAN COGNITIEVE GEDRAGSTHERAPIE

In 1979 bes1oot de Maastrichtse Goldsteinprojectgroep om naast de serie interpersoonlijke vaardigheidstherapieën ook een serie persoonlijke vaardigheidstherapieën te ontwikkelen. Een en ander in navolging van Golldstein e.a. (1976) en aanslultend aan de literatuur met betrekking tot de behoeften van clienten uit de lagere socilal-economische klassen (Rapaport, 1962; Schmidt, Smart en Moss, 1968; Trower, Bryant en Argyle, 1978; Bedel1, Archer en Marlowe, 1980 ).

Deze persoonlijke vaardigheidstherapieën kunnen als een worm van 
"cognitive behavioral interventions" worden opgevat en wel vanwege het felt dat het aanleren van de vaardigheden plaats vindt door middel van diverse vormen van gedragsoefening; verbale overtuiging en cognitieve herstructurering. Tijdens deze vaardigheidstherapieën worden aan de deelnemers daaraan behandelingsstrategieën aangeleerd die coverte en overte gedragsaspecten omvatten.

Conform de in 4.3 behandelde indeling sluiten de in Mastricht ontwikkelde persoonlijke vaardigheidstherapieën eveneens aan bij de probleemoplos-therapieën zoals besproken in 4.3.3.

Tijdens deze persoonlijke vaardigheidstherapieën leert men de deelnemers daaraan immers algemene handelingsstrategieën aan met behulp waarvan zij uiteenlopende soorten probleemsituaties weloverwogen en doelgericht kunnen afhandelen. Men streeft ernaar de aan te leren strategie in de meest uiteenlopende soorten probleemsituaties in te oefenen. Dit inoefenen gebeurt aan de hand van een aantal vooraf vastgestelde gedragsregels, ook wel leerpunten genoend. Deze leerpunten operationaliseren de verschilliende fasen van het probleemoplosproces, die men de deelnemers wil aanleren. Er is sprake van een pragmatisch gerichte therapievorm die toch voldoende ruimte biedt voor de uniciteit van de individuele client. Elke deelnemer wordt immers aangespoord een elgen versie van de aangeboden algemene strategie te ontwikkelen.

Men kan ook een belangrijk verschil constateren tussen de in 4.3.3. beschreven problem-solving-therapieën en de in dit proefschrift beschreven persoonlijke vaardigheidstherapieën. De in 4.3.3. besproken therapieën worden veelal als programma "an sich" aan clienten aangeboden terwijl de persoonlijke vaardigheidstherapieën alhier beschreven, steeds onderdeel vormen van een ruimer opgezet behandelingsplan en dus slechts een deelaspect van een meer uitgebreide behandeling vormen. 
Naast positief commentaar op de ontwikkelingen in cognitieve richting, geeft de betreffende $1 \mathrm{iteratuur}$ ook een aantal punten van kritiek weer (Mahoney, 1977a, 1977b, 1980; Mahoney en Arnkoff, 1978; P. Eelen, $1982 \mathrm{a}$ en 1982b; H. Landsheer, 1983). Deze punten van kritiek betreffen:

a. de wijze warop men het concept cognitie definieert. Diverse auteurs geven verschillende definities voor dit concept. Er bestaat geen overeenstemning over het feit of dit concept verwijst naar een discrete gebeurtenis of naar een proces.

b. de wijze waarop men cognities meet c.q. opspoort. Cognities worden veelal geidentificeerd met interne zelfspraak. Eventuele aanwezigheid van cognities alsook de inhoud(en) daarvan zijn niet voor directe observatie toegankelijk. Een en ander wordt veelal op indirecte wijze vastgesteld.

c. de wijze waarop cognitieve technieken en procedures worden beschreven. De grens tussen therapeutische interventies die cognities als aangrijpingspunt tot verandering kiezen en interventies die gedrag als aangrijpingspunt tot verandering kiezen, is vaak moeilijk te trekken. Wat de meeste behandelingsprogramma's betreft, is er sprake van mengvormen met accentverschfllen.

d. het feit dat in cognitieve gedragstherapleën veelal wordt uitgegaan van het isomorfisme tussen woorden en beliefs. Men verondertelt dat woorden - in de vorm van directe verbale expressies maar ook in de vorm van interne dialogen c.q. interne zelfspraak - cognities adequat en volledig representeren. Er wordt meestal geen onderscheld gemaakt tussen bewust en onbewust verlopende cognitieve processen. De meeste auteurs veronderstellen dat cognities steeds als bewuste inferentie- en labelingsprocessen kunnen worden opgevat. Eelen (1982b) stelt echter dat men wat cognities betreft een onderscheid kan maken tussen automatische processen en gecontroleerde processen. Automatische processen verlopen zeer snel en zonder dat bewuste aandacht daarbij een rol speelt. Gecontroleerde processen verlopen daarentegen serieel, intentionee1, mèt bewuste aandacht en zijn 
In tegenstelling tot automatische processen in principe wel verbaal toegankel ijk.

e. integratie-problemen wat betreft cognitieve psychologie en cognitieve gedragstherapie. De plaats van cognities in het Stimulus Organisme - Respons - Consequentie (afgekort SORC-) schema is momentee1 heftig in discussie (Burger, 1983; Orlemans, 1983; Landsheer, 1983; Eelen, 1982a). Orlemans (1983) is van mening dat cognities als 0 -variabelen moeten worden opgevat. Dit betekent dat hij cognities niet als "covert operants" beschouwt. Burger (1982) daarentegen beschouwt cognities als R-variabelen en daarmee als coverants. Eelen (1982a) is van mening dat cognities niet zomaar als "covert operants" kunnen worden opgevat. Hij definieert cognities als uitspraken over gedrag en de gevolgen daarvan (vgl. Bandura, 1977). Deze uitspraken als zodanig kunnen zijns inziens niet direct beïnvloed worden door beloning en/of straf. Men kan cognities wel indirect in de werkel ijkheid gaan toetsen. Bij deze toetsing spelen omgevingscontingenties een belangrijke ro1. Op basis van de ervaren contingenties kan het individu besluiten zijn opvattingen over de werkelijkheid (=cognities, beliefs) te handhaven of te verwerpen.

$f$. het feit dat in de cognitieve gedragstherapie rationaliteit veelal gelijkgesteld wordt aan psychische gezondheid. 
HOOFDSTUK 5. ALGEMEEN THEORETISCHE ONTWIKKELINGEN EN HUN IMPLICATIES WOOR VAARDIGHE IDSTHERAPIEEN

\subsection{INLEIDING}

Sinds 1950 kan men constateren dat er in de psychologische theorievorming steeds meer aandacht wordt besteed aan de roll van cognitieve factoren bij het tot stand komen van gedrag(sverandering). Cognitieve factoren worden inmiddels als belangrijke gedragsdeterminanten apgevat. In de cognitief sociaal-1eertheoretische modellen wordt gedrag steeds opgevat als een resultante van een wederzijdse beinvloeding van persoon en situatie. Feitelijk gedrag leidt tot een (al dan niet beoogde) verandering van de situatie en leidt tot een bevestiging of bijsturing van de cognities betreffende eigen competenties en mogelijkheden.

Attributies, etiketteringen, interpretaties van situaties en verwachtingen ten aanzien wan eigen mogel ijkheden sturen het gedrag van een individu in belangrijke mate. In dit hoofdstuk zullen 3 psychologische theorieën worden beschreven die gedrag opvatten als de resultante van een wederzijdse beïnvloeding van persoon en situatie en waarin cognitieve concepten in de zin van attributies, etiketteringen, verwachtingen een centrale rol spelen. Achtereenvolgens zal aandacht worden besteed aan de theorieën van Rotter $(1954)$, Bandura $(1969,1977)$ en Lazarus (1966).

In de theorie van Rotter ligt de nadruk op verwachtingen, reinforcement-contingenties en beheersingsoriëntatie.

Bandura ontwikkelde een cognitieve sociale leertheorie met behulp waarvan men het tot stand komen van gedrag(swerandering) kan verkiaren. Persoonlijke competentie-verwachtingen en respons-uitikomstverwachtingen vormen de pijlers waarop deze theorie is opgebouwd. Lazarus werkte een stressmode1 uit, gebaseerd op de informatieverwerkingsmodellen uit de experimentele psychologie waarin attributie-processen 
een belangrijke rol spelen.

Bestudering van deze theorieen leidt tot de conclusie dat de beschikbaarheid vam een geëigend persoonlijk en interpersoonlijk gedragsrepertoire geen voldoende voowwaarde vormt voor het metterdaad stellen van dergelijk gedrag. Bovendien kan men concluderen dat vaardigheidstherapie-programma"s, gericht op werandering van persoonlijk en interpersoonlijk gedrag, ook aandacht zullen moeten besteden aan het tot stand komen van realistische zelfbeweringen, verwachtingen en attributies. In het nu volgende zal daarom aandacht worden besteed aan de implicaties van de eerder genoemde theorieën voor peroonijjke en interpersoonlijke vaardigheidstherapieën à la Goldstein. Dit hoofdstuk omvat tevens een beknopte beschrijuing van de opkomst van cognitieve verklaringsmodellen ten aanzien van de wijze waarop leerprocessen verlopen. Ook wordt een poging gedaan de in de theorieèn van Rotter, Bandura en Lazarus beschreven concepten in één model te verenigen.

In 5.8. tenslotte, wordt een samenvatting gegeven van de wijzen waarop de door Bandura, Rotter en Lazarus ontwikkelde theoretische principes en uitgangspunten worden geoperationaliseerd tijdens de uitvoering van de persoonlijke vaardigheidstherapieën. In 5.8.1. wordt weergegeven op welke wijzen de persoonlijke competentie-verwachting(en) van de deelnemers worden beinnloed. In 5.8.2. wordt aandacht besteed aan de wijzen waarop men de respons-uitkomst-verwachtingen van de deelnemers tracht te optimaliseren.

5.2. DE OPKOMST VAN COGNITIEVE VERKLARINGSMODELLEN TEN AANZIEN VAN DE UTAZE WAAROP LEERPROCESSEN VERLOPEN, IN VOGELVLUCHT BE-

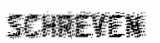

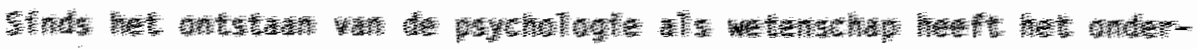

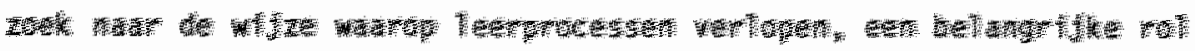

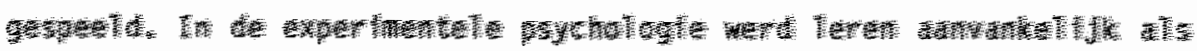

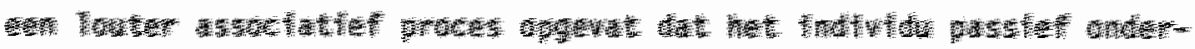

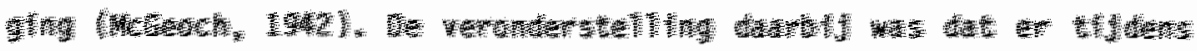

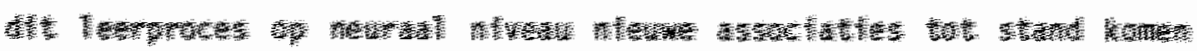

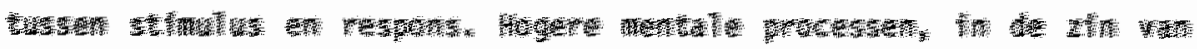


warneming, beoordeling, symbolisering etc. speelden in deze opvattingen nauwelijks een rol. Men ging uit van een natuur-wetenschappelijk wetenschapsmodel. Pavlov's experimenten (1955, 1960) met betrekking tot het aan- en afleren van geconditioneerde reflexen bij honden zijn gebaseerd op de principes van het assoclatief leren. De door Pavlov ontdekte wetmatigheden worden aangeduid als klassieke conditionering. Bij het aanleren van geconditioneerde reflexen dienen de reeds aanwezige, aangeboren reflexen als uitgangspunt. Leerprocessen worden bepaald door manipulaties van buitenaf met betrekking tot de stimuluskant van een bepaald gedrag. Teneinde de bevindingen bij zijn inmiddels $k 1$ assiek geworden salivatie-experimententen te verklaren veronderstelde Pavlov dat de associatie tussen geconditioneerde stimulus en (on)geconditioneerde respons tot stand kwam op basis van een nieuwe neurale verbinding tussen deze beide. Het experimenteel onderzoek van deze auteur vormt een eerste mijlpal in de psychologie wat betreft de ontwikkeling van een coherente theorie en een eenduidig taalgebruik met behulp waarvan men processen die optreden bij het aanleren van gedrag kan verklaren.

Voortbouwend op het werk van Pavlow kwam Skinner $(1938,1953)$ op basis van gevarifeerde dierexperimenten tot de conclusie dat een groot aantal gedragingen van dieren verklaard kon worden vanuit aanwezige omgevingscontingenties. Ter onderscheiding van de klassieke conditionering à la Pavlov worden de door Skinner ontdekte wetmatigheden aangeduid als operante conditionering. Het operante conditioneringsmodel beschouwt de omgevingsreacties op een bepalde respons als een centraal element in het leerproces. Zowel het $k 1$ assieke als het operante conditioneringsmodel hanteren het behavioristische $S-0-R$ schema als uitgangspunt.

Het klassieke model kent een centrale rol toe aan stimulus substitutie, het operante model aan de beinvloeding van respons-reinforcement contingenties. Het feit dat Pavlov neurologische termen hanteert en Skinner functionele, vormt een essentieel onderscheid tussen deze twee paradigma's. Beide auteurs gaan overigens uit van de vooronderstelling dat elke vorm van gedrag verklaard kan worden door middel van 1 ineaire relaties tussen overte responsen en omgevingsstimul1. Mediërende processen in het organisme hebben in de door hen ontwikkelde theorieën 
geen plats. Toepassing van klassieke en operante conditioneringsprinclpes blj de verklaring van camplex menselijk gedrag, bracht in de loop van de tijd een aantal probiemen aan het licht (Lachman e.a., 1979). Genoemde principes bleken nlet in staat complex menselijk gedrag afdoende te verklaren. Een halve eeuw onderzoek met betrekking tot k1assieke conditioneringsprincipes leverde steeds meer evidentie op voor de rol van motivationele en emotionele factoren bij het tot starid komen van complex menselijk gedrag (McGuigan en Lumsden, 1973; Prokasy, 1965). In het klassfeke stimulus - organtsme - respons model werden deze factoren gelocaliseerd in de zogenaamde "black box" van het organisme. Men ging ervan uit dat deze factoren miet nader geconcretiseerd $\mathrm{c} . \mathrm{q}$. onderzocht konden worden. onderzoek ten aanzien van dergelfjke factoren - ook wel aangeduid als "hogere" mentale functies - paste niet in een natuurwetenschappelijk wetenschapsmodel.

op den duur werd echter duidelijk - op basis van experimenteel onderzoek als ook klinische ervaring - dat het klassieke en het operante conditioneringsparadigma - ieder an sich - simplistische reducties vomiden van een zeer complexe werkelijkhelld lHornton en Turnage, 1976). Verbale conditioneringsexperimenten (Dulany, 1968; Jacobson, 1969; Splelberger en De Nike, 1966) toonden aan dat verbale conditioneringseffecten alleen optraden bij proefpersonen die inzicht hadden in de betreffende respons-reinforcement contingentie $(s)$.

De term respons-reinforcement contingentie(s) verwijst naar het feit dat het individu een relatie ervaart tussen zijn eigen gedrag en de belonende gevolgen daarvan. De geciteerde verbale conditioneringsexperimenten bevestigen de verondersteling dat cognitieve factoren een belangrijke rol spelen bij conditioneringsprocessen. Met de invoering van computermodellen in de psychologische research als simulatie van complex menselijke leerprocessen werd duldelijk dat lerem als een actief informatle-verwerkingsproces moest worden opgevat. Daamee eindigde het tijdperk van de louter associationistische opvattingen. Newell en Simon (1972) en Anderson en Bower (1973) komen aan de hand van de eerder genoemde computer analogleën met betrekking tot complex mensel 11jk gedrag tot de conclusie dat leren moet worden opgevat als een proces waarin opname, opslag en verwerking van informatie essentieel zign. Miller. Gallanter en Pribram's boek met als titel "Plans 
and the structure of behavior (1960) vormde de eerste mijlpaal wat de ontwikkelingen in cognitieve richting betreft. In dit werk werd de aanzet gegeven tot het ontwikkelen van cognitief georiënteerde verklaringen met betrekking tot complex menselijk gledrag.

In tabel 5.1. wordt een overzlcht gegeven van de wijze waarop Merluz21, Rudy en Glass (1981) de verschillen tussen de associationistische en de op verwerking van informatie gebaseerde verklaringsmodellen samenvatten.

Tabel 5.1. Beschrljuling van verkl er Ingsmodellen conform Merluzzl, Rudy on G(ass (1981)

\begin{tabular}{|c|c|c|}
\hline & Assoclationll sin & Hnformat Ion processing \\
\hline $\begin{array}{l}\text { Mertasclentif lo } \\
\text { ass umptlans }\end{array}$ & $\begin{array}{l}\text { Mlind is passlve } \\
\text { Behawlor is product } \\
\text { of the environment } \\
\text { Tabul rasa } \\
\text { Behavior is modiflable }\end{array}$ & $\begin{array}{l}\text { Mind is dynamlic and active } \\
\text { Behawlor is a product of } \\
\text { mental acts } \\
\text { Innate propertios } \\
\text { Mind is modiflable }\end{array}$ \\
\hline Subject Matter & $\begin{array}{l}\text { Performance } \\
\text { Conditloning } \\
\text { Testing learning theory }\end{array}$ & $\begin{array}{l}\text { Mental processes } \\
\text { Thought and I anguage } \\
\text { Comprohems lon and kmowl edge }\end{array}$ \\
\hline Methodologlas & $\begin{array}{l}\text { Reversal and multiple } \\
\text { basel lne deslgns } \\
\text { classlcal and operant } \\
\text { research paradgms }\end{array}$ & $\begin{array}{l}\text { Convargent val ldatlom tech- } \\
\text { niques } \\
\text { Uise of reaction time to } \\
\text { decouple cognitlive processes } \\
\text { Computer simulatlons }\end{array}$ \\
\hline Concepts & $\begin{array}{l}\text { Stlmul us, respons, } \\
\text { assoclatlons, reinfor- } \\
\text { cemert, Incentlives. } \\
\text { and so forth }\end{array}$ & $\begin{array}{l}\text { Input, output, encodimg, stom } \\
\text { rage, retr laval, competence } \\
\text { executive procensor, primary } \\
\text { and secomdary menory, and so } \\
\text { forth }\end{array}$ \\
\hline Theor les: & Hecham Istlc: $5-r-s-R$ & $\begin{array}{l}\text { Computer l lke: mlma, a rula } \\
\text { governs loarn lng }\end{array}$ \\
\hline
\end{tabular}

Scheme ontllend an Marluzzl, Rudy, GIass, 1981 .

Bovenstaand schema geeft het verschil tussen de eerder genoemde opvattingen in absolute termen weer. In werkelijkheid biljken er ook opvattingen te bestaan, die tot het grensgebied van beide paradigmata gerekend kunnen worden en zodoende een mengeling vormen vam kenmerken van beide verklaringsmodellen samen.

Uit dit schema blijkt dat er wezenlijke verschillen bestaan tussen het 
associationistlsche paradigma en het paradigma gebaseerd op informatle-verwerkingsmodellen wat betreft:

- vooronderstel1ingen

- object van onderzoek

- gehanteerde concepten

- theorie-vorming

In tegenstelling tot de associationistische opvattingen leggen de informatieverwerkingsmodellen de nadruk op de bestudering van de invloed van zgn. hogere mentalle processen als denken en taal bij het tot stand komen van gedrag. Men richt sterk de aandacht op de invloed van cognitieve processen en functies.

Naast de computer-modellen vormde ook het werk van Piaget (1932) een belangrijke stimulans in cognitieve richting. Piaget bestudeerde de coginitieve ontwikkeling van het individu. Hij richtte $z i j n$ aandacht vooral op de gevolgen van de interactie tussen individu en omgeving voor diens ontwikkeling op sociaal, emotioneel en intellectueel vlak en wel vanult de veronderstelling dat mentale structuren de ervaringen van het indiwidu organiseren en zodoende diens gedrag reguleren. Piaget vat het zich ontwikkelende kind op als eem actief informatie verwervend en informatieverwerkend systeem en nièt als een louter passieve ontvanger van omgevingsstimuli.

Miller en Dollard (1941) ontwilerpen als eersten binnen de leertheoretische traditie een conditioneringsmodel waarbij ze de nadruk legden op de functle van "hogere mentale processen" zoals aandacht en symbolisering. Deze nieuwe stroming in de leertheorie werd naderhand aangeduid als de sociale leertheorie. Rotter (1954) en Bandura (1969; 1974; $1977)$ werkten deze sociale leertheorie elk op hun eigen wijze verder uit. Rotter ontwikkeide een versie van deze theorie die de nadruk legt op de begrippen reinforcement-waarde en verwachtingen (zie 5.3.1.). Bandura ontdekte het principe van het "wicarieus leren" en ontwikkelde de "self-efficacy" theorie ter verklaring van het al dan miet tot stand komen van gedrag(swerandering) bij het individu.

Bandura"s anderzoek met betrekking tot sociale leerprocessen bijk inderen leverde resultaten op die strijdig zijn met de operante condithoneringsprincipes van Skinner (Bandura, 1969). De term vicarieus leren verwijst naar de leerprocessen die kunnen optredien bij het ge- 
tuige zijn van gedrag van anderen. Het geobserveerde gedrag blijkt dan een zogenaamde model-functie te vervullen. Bandura ondektde dat leerprocessen ook indirekt kunnen verlopen zonder direkte aanwezigheid van ongevingscontingenties. Skinner beschouwde de direkte aanwezlgheid van dergelijke contingenties als sine qua non woor het optreden van leereffecten. Het werk van Bandura bevestigde nogmaals dat symboliseringsprocessen een belangrijke rol spelen bij het aanleren van complex menselijk gedrag. Bandura's "self-efficacy" theorle (zie 5.3.2.) beoogt het al dan niet optreden van gedragsverandering(en) te verklaren met behulp van verwachtingsconcepten. Het individu wordt als een actief informatie verwervend en informatie verwerkend systeem opgevat (Bandura, 1977).

Bovenstaande leidt tot de conclusie dat de opvattingen over de wijze waarop leerprocessen verlopen, de laatste decennia aan sterke veranderingen onderhevig zijn geweest. De aanvankelijk enigszins simplistische en reductionistische conditioneringsmodellem hebben plaats gemaakt voor complexe cognitief georiënteerde verklaringsmodellen die meer recht beogen te doen aan de complexe leerprocessen die bij het menselijk functioneren een rol spelen. Wat het $k l$ assieke en operante conditioneringsmodel betreft, geldt dat beide modellen waarde behouden bij de verklaring van bepaalde deelaspecten die ook bij complex mense$1 \mathrm{ijk}$ gedrag een rol spelen. Beide modellen hebben een bellangrijke bijdrage geleverd aan de ontwikkeling van specifieke interventietechnieken voor de psychologische praktijk. Opvattingen over de wijze waarop leerprocessen verlopen, hebben repercussies op het viak van persoonlijkheidsleer, psychopathologie, psychotherapie c.q. de leer van de gedragsmodificatie. Op al deze terreinen speelt de relatie tussen emotie en cognitie een belangrijke rol. De traditionele conditioneringsopvattingen beschouwen emoties als autonome $k 1$ assiek geconditioneerde responsen. De cognitief georiënteerde opvattingen daarentegen leggen de nadruk op de rol van de beoordelings- c.q. appralsal-functle als mediator tussen stimulus en emotionele respons (Murray, 1964). De beoordeling wan een bepalde situatie blijkt afhankelijk te zijn van de hoeveelheid beschikbare informatie, kenmerken van de situatie zowel als typische kenmerken en eigenschappen van het betreffende individu. 
Bedoelde beoordelingsprocessen kumen in princlpe zowel onbewust, automatisch, reflexmatig alsook bewust, intentioneel verlopen. De moelzame voortgang van het onderzoek naar aard, inhoud en verloop van deze processen toont de weerbarstigheld en complexiteit van deze materife aan.

Cognitief georiënteerde opvattingen lleiden tot anderssoortige therapeutische interventies dan de traditionele conditioneringsopvattingen. Eerstgenoemde benaderingen stellen de beinvloeding van cognitieve aspecten centraal terwijl laatstgenoemde uitdoving van emotionele responsen nastreven.

\subsection{KEUZE VAN DRIE RELEVANTE VERKLARINGSMODELLEN}

De in hoofdstuk 1 en 2 besproken vaardigheidstherapieën zijn erop gericht veranderingen in gedrag en cognities tot stand te brengen bij de deelmemende clienten. De leerprocessen die bij deze vorm van vaardigheidstherapie aan de orde zijn, kunnen niet afdoende verklaard worden met behulp van traditionele conditioneringsmodellen. Cognitieve processen blijken een belangrijke rol te spelen. Dit impliceert dat bij pogingen theoretische verklaringsmodellen te vinden, die de wijze waarop deze leerprocessen verlopen, kunnen verklaren, aansluiting gezocht moet worden bij primair cognitief georiënteerde opvattingen. In het nu volgende worden successievelijk de theorieën van Rotter (1954), Bandura (1969, 1977) en Lazarus (1966) besproken op hun relevantie voor de in hoofdstuk 1 beschreven persoonlijke zowel als interpersoon7 ijke vaardigheidstherapieën. Deze theorieën hebben met elkaar gemeenschappelijk dat ze gedrag en emoties niet unidirectioneel trachten te verklaren maar uftgaan van de vooronderstelling dat gedrag, emoties en ook andere persoonlifkheldskenmerken en omgevingsinvloeden elkaar reciprook determineren. Er wordt een centrale rol toegekend aan de invloed van cognitieve beoordelingsprocessen. 
In het nu volgende zal het model van Rotter worden beschreven, alsook de implicaties daarvan voor vaardigheidstherapieän.

\subsubsection{Beschrijuing van het model}

De door Rotter $(1954,1966,1975)$ ontwikkelde sociale leertheorie gaat uit van de veronderstelling dat gedrag een functie vormt wan verwachtingen en reînforcement-waarde. De verwachtingen betreffen de subjectief ervaren warschijnlijkheid(heden) dat het eigen gedrag al dan niet een bepaald effect tot gevolg zal hebben (respons $\rightarrow$ gevolg). Deze verwachtingen zijn het product van de cognitieve verwerking van eerdere ervaringen in soorgelijke situaties. Het begrip reinforcementwaarde verwijst naar de waarde die het individu toekent aan de (mogelijke) gevolgen van zijn eigen gedrag. Een positieve persoonlijke waardering van deze gevolgen impliceert dat er sprake is van door het individu gewenste gevolgen. Een negatileve persoonlijke waardering impliceert dat er sprake is van gevolgen die aversief zijn voor het betreffende individu. Deze waarderingen zijn niet uniform van aard maar subjectief bepaald. Rotter is van mening dat gedrag in sociale situaties aan- en afgeleerd wordt door middel van de beloningen die al dan niet op dat gedrag volgen $(\mathrm{vg})$. het operante conditioneringsmodel van Skinner). Hij ste1t voorts dat het effect van de betreffende beloningen voor een belangrijk deel bepaald wordt door de mate waarin het individu een causale relatie ervaart tussen zijn elgen gedrag en de al dan niet reinforcerende gevolgen daarvan. Het gaat dus an de mate van controle die een individu ervart in de relatie tussen eigen gedrag en omgeving. De auteur spreekt in dit verband over een interne versus externe locus of control. Het begrip interne locus of control impliceert dat een individu de algemene verwachting koestert dat er een causale relatie bestaat tussen zijn eigen gedrag en de gevolgen daarvan. Individuën met een overwegend interne locus of control zullen zich dan ook zelf sterk inspannen om door hen gewenste doelen daadwerkeljjk te bereiken. Personen met een overwegend externe locus of control wijten de 
gevolgen van elgen gedrag primair aan het (nood)lot, toeval, gelluk en/ of de macht van anderen. Individuërn met een dergelijke locus of control zullen zich zelf minder inspannen om door hen gewenste doelen ook werkelijk te berelken, waardoor hun kansen op succeservaringen evenredig veriminderen.

Het begrippenpar interne-externe locus of control wordt in de 1iteratuur aangeduld als het $\mathbb{I}-E$ begrip, waarbij I verwijst naar een interne locus of control en $E$ naar een externe locus of control. De basis voor de I-E oriëntatie op volwassen leeftijd wordt volgens Rotter gelegd in de kindertijd. Aard en aantal van de reacties uit de omgeving op het gedrag van het kind bepalen welke beheersingsorfëntatie dit kind in de loop van de tijd zal ontwikkelen met betrekking tot de gevolgen van eigen gedrag. Is er sprake van veelvuldige responscontingente stimulering, dan zal het kind op den duur een overwegend interne beheersingsorfëntatie opbouwen. Vindt er daarentegen weinig responscontingente maar we1 veel stimuluscontingente stimulering plaats dan zal op den duur een overwegend externe beheersingsoriëntatle tot stand komen. De term responscontingente stimulering impliceert dat elke respons die gestelld wordt meteen beantwoord $c . q$. beloond wordt met een reactie daarop uit de omgeving. Stimuluscontingente stimulering verwijst naar het feit dat het kind gebombardeerd wordt met stimuli van buitenaf onafhankel ijk van de eigen respons.

De op basis van de persoonlijke leergeschiedenis van het individu bij hem tot stand gekomen beheersingsoriëntatie zal op den duur kwantiteit zowel als kwaliteit - dat wil zeggen frequentie zowel als aard - van het door het individu te stellen gedrag gaan bepalen. Aangezien beide oriëntaties zichzelf (kunnen) bekrachtigen, kunnen er vicieuze cirkelprocessen ontstaan waarin interne oriëntaties steeds meer intern worden en externe oriëntaties steeds meer extern. Verwachtingen en feite$11 j k$ gedrag blijken dus wederzijds aan elkaar gerelateerd.

Figuur 5.1. geeft deze cirkelprocessen schematisch weer. 


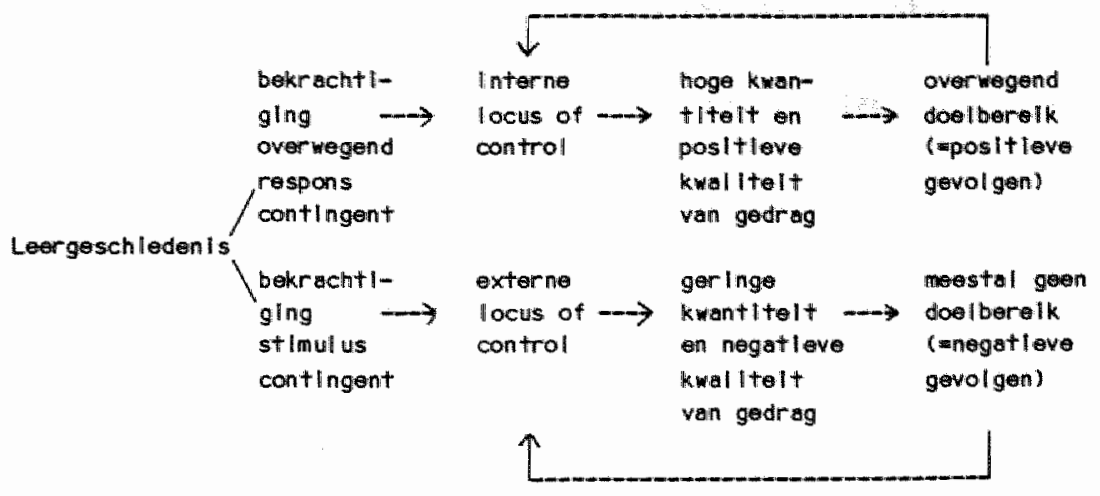

Fliguur 5.1. De relatle tussen aard van de beheersingsorlentatle an feltelljk godrag

Ofschoon Rotter geen uitspraken doet over de mogel ijke gevolgen van een externe oriëntatie, is het op langere termijn waarschijniljk dat juist door het gebrek aan succeservaringen een externe oriëntatie op den duur aanleiding zal geven tot apathie- c.q. verminderde gedragsfrequentie en een depressief affect tengevolge van een steeds sterker wordende geleerde hulpeloosheid (Seligman, 1975).

Rotter (1975) is van mening dat de beheersingsorientatie van het individu een persoonl ijkheidskenmerk vormt dat redelijk stabiel is over diverse situaties. Toch bijjkt de predictieve waarde van dit construct met betrekking tot specifiek gedrag in specifieke situaties beperkt (Lefcourt 1966, 1976). Rotter (1975) is van mening dat de predictieve waarde van het $I-E$ construct het grootst is in situaties die nieuw zijn voor de persoon en/of ambigu van aard onder voorwaarde dat het in de betreffende situatie te stellen gedrag voldoende reinforcementwaarde heeft voor de persoon.

Het begrip locus of control kan dus als een belangrijke determinerende variabele worden opgevat bij het al dan niet stellen van gedrag. Extern gecontroleerden, ook wel externals genoend, zullen niet snell actief ingrijpen in hum eigen situatie, teneinde hun problemen en/of $\mathrm{klachten}$ op te lossen. Ze verwachten immers weinig effect van eigen handelen. Intern gecontroleerden, ook wel internals genoemd, zullen daarentegen wellicht meer gemotiveerd zijn hun problemen en/of klachten actlief aan te pakken. 
Lefcourt (1966, 1976) en Phares (1976) beschrijven intern gecontroleerden in vergelijking tot extern gecontroleerden als mensen die:

- meer initiatieven nemen

- meer verantwoordelijkheld op zich nemen in prestatiesituaties

- actief informatie verzamelen

- de eenmal verzamelde informatie efficienter gebruiken

- meer oog hebben voor omgevingskenmerken.

Miller (1983) bestudeerde de relatie tussen beheersingsoriëntatie en zlektegedag. Op basis van literatuurstudie kwam hij tot de conclusie dat de aard van de beheersingsoriëntatie gevolgen heeft voor de wijzen waarop chronische patienten met hun ziekte omgaan. Extern gecontro1 eerden bleken vaker gebruik te maken van ontkenning en veelvuldiger gebukt te gaan onder schuldgevoelens. Passief, inactief als ze waren deden ze weinig of geen pogingen zelf iets aan hun situatie te veranderen. Intern gecontroleerden bleken in een dergel ijke situatie actiever op te treden. Ze verzamelden informatie over hun ziekte, besteedden zorg en aandacht aan zichzelf, stelden doelen en namen beslissingen. Tabel 5.2. geeft een overzicht van de door Miller (1983) geconstateerde relatie tussen beheersingsoriëntatie en ziektegedrag.

Tabul 5.2. Rellatle tussen beheersingsorlentatio on zlektegedrag conform Mit1 1 or (1983)

\begin{tabular}{|c|c|c|}
\hline & Internals & Externals \\
\hline $\begin{array}{l}\text { Role definltion and } \\
\text { satis iaction }\end{array}$ & $\begin{array}{l}\text { More clear ly def ined: } \\
\text { more satisfylng }\end{array}$ & $\begin{array}{l}\text { Less clearfy defl ned } \\
\text { less sat l sfylng }\end{array}$ \\
\hline $\begin{array}{l}\text { Relating to author lty } \\
\text { Selt-asteren }\end{array}$ & $\begin{array}{l}\text { Peer-1 lke Interactilons } \\
\text { Higher or more stabte } \\
\text { selt-esteem }\end{array}$ & $\begin{array}{l}\text { Passive-like Interactions } \\
\text { Lower or less stable } \\
\text { self-esteen }\end{array}$ \\
\hline $\begin{array}{l}\text { Responslibillty for } \\
\text { sel t-care }\end{array}$ & $\begin{array}{l}\text { Actl ve knowledgo- } \\
\text { soek Ing behavlor }\end{array}$ & $\begin{array}{l}\text { Do not actiwely seek } \\
\text { information, accept what } \\
\text { is glven }\end{array}$ \\
\hline $\begin{array}{l}\text { Compl I ance with has th- } \\
\text { cane reglanen }\end{array}$ & Man lpul ate reglman & Campllant \\
\hline Confldence In ablllties & Self-conflldent & Lack self-confldent \\
\hline $\begin{array}{l}\text { Probl en-solving ablli- } \\
\text { tles }\end{array}$ & More successtut & Less sulccosstul \\
\hline Goat s-setting behav lor & Reallstlc In goels set & Unreallistlic \\
\hline Lawel of motivation & Mot I vation & $\begin{array}{l}\text { Tend tow tord helplessness } \\
\text { at tlmes }\end{array}$ \\
\hline $\begin{array}{l}\text { linvol vement in declsion } \\
\text { making }\end{array}$ & More Invol vement & Less Inval vement \\
\hline
\end{tabular}




\subsubsection{Implicaties voor vardigheidstherapieën}

Uit de socjale leertheorfe van Rotter kan men een aantal consequenties trekken wat betreft:

a. opzet en uitvoering van de in dit proefschrift beschreven vaardigheidstherapieen.

b. de indicatie-stelling dartoe,

c. mogelijke effectiviteitscriteria bij de evaluatie van de effecten daarvan.

ad.a. Conform Rotter dienen opzet en uitvoering van de alhier beschreven vaardigheidstherapieën erop gericht te ziln de beheersingsorientatie van de deelnemers in meer interne richting on te buigen. Bij deze ombuiging kan het principe van de responscontingente bekrachtiging een belangrijke rol spelen. Toepassing van dit principe op de hier beschreven vaardigheidstherapleën impliceert dat:

- men de deelnemers aan deze vaardigheidstherapieën aan den $11 j$ ve laat ervaren dat er positieve witkams ten verbonden zijn aan de door hen gestelde responsen. De deelnemers leren op deze wijze dat het tonen van eigen inzet daadwerkelijk doelberelk tot gevolg heeft.

- men de deelnemers realistische respons-uitkomst informatie dient te verschaffen zowel bij modeling als bij gedragsoefening.

ad.b. Wat de indicatie-stelling betreft, kan men op basis van de in 5.3.3.1. beschreven onderzoeksresultaten (Lefcourt, 1966; Mi1ler, 1973; Lefcourt, 1976; Phares, 1976) veronderstellen dat extern gecontroleerden bij ultstek in aanmerking komen voor deel name aan vaardigheldstherapleën à la Goldstein. Tijdens deze vaardigheidstherapieen streeft men er immers naar de deelnemers meer initiatieven te doen memen en meer verantwoordelijkheld op zich te laten nemen in door hen als problematisch ervaren situaties. Dit betekent dat men door deelname aan de hier beschreven vaardigheidstherapleën een meer interne Tocus of control na- 
streeft. Abramowitz (1972), Kilman e.a. (1975), Kilman en Sotile (1976), Schwartz en Higgins (1979), Koppelaar en Vlaander (1983) toonden bovendien aan dat externals meer en beter leren in een gestructureerde leersituatie en internals meer in een ongestructureerde leersituatie warin ze een behoorlijke mate van vrijheid en ruimte voor eigen inbreng ervaren. Bovenstaande impliceert dat extern georiënteerden het meest van de hier beschreven vaardigheidstherapieen kunnen profiteren.

ad.c. Het model van Rotter suggereert dat het concept "locus of control" weleens een belangrijk effectiviteitscriterium zou kunnen vormen bij de evaluatie van de effecten van gedragsmodificatieprogramma's. Aangezien de in dit proefschrift beschreven persoonlijke vaardigheidstherapieën erop gericht zijn deelnemers te leren actiever en doelgerichter on te gaan met door hen als problematisch ervaren situaties, lijkt het zinvol het concept "locius of control" als effectiviteitscriterium in aanmerking te nemen. In het in hoofdstuk 7 beschreven effectiviteitsonderzoek zal derhalve worden nagegaan in hoeverre deelname aan persoon11jke vaardigheidstherapieèn à la Goldstein aanleiding geeft tot verandering van I-E orientatie in meer interne richting.

\subsubsection{Het cognitief sociaal-1eertheoretisch model van Bandura}

\subsubsection{Beschrijuing van het model}

In 1977 publiceerde Bandura de door hemzelf ontworpen "self-efficacy" theorle als verklaringsmodel voor de wijze waarop gedrag(sverandering) tot stand komt. Het individu wordt daarbij als een actief informatileverwerkend-systeem opgevat. Attributieprocessen spelen in deze theorie een centrale rol.

Bandura gaat utt van de vooronderstelling dat de verwachtingen die individuën hebben ten aanzien van hun eligen kunnen frequentie en intensiteit van gedrag bepalen. De auteur is van mening dat "self-effica$c y$ ", door hem ook wel aangeduid als "sense of personal mastery" en 
door Beekers (1982) vertald als "persoonlijke competentie-verwachting" de belangrijkste gedragsdeterminant vormt.

Bandura maakt een zeer nadrukkelijk onderscheid tussen persoonl ijke competentie-verwachting(en) en respons-uitkomst-verwachting(en). Het begrip persoonlijke competentie-verwachting(en) wordt door hen uitgewerkt wat betreft consequenties voor de psychotherapeutische praktijk. Het begrip respons-uitkonst-verwachting(en) niet. De persoonlijke competentie-verwachting betreft de mate waarin een individu zichzelf in staat acht een welomschreven doelgedrag al dan niet te stellen. Deze verwachting is individu-specifiek en kan tevens situatie- en tijjspecifiek zijn. Ze vormt de resultante van subjectieve beoordelingsprocessen. Deze verwachting heeft dus betrekking op de relatie tussen persoon, gedrag en situatie.

Het begrip respons-uitkomst-verwachting daarentegen heeft betrekking op de relatie tussen een bepaald gedrag en de gevolgen daarwan. Deze verwachting heeft dus niet alleen betrekking op het eigen functioneren maar is veel algemener van aard. Persoonlijke competentie-verwachtingen en respons-uitkomst-verwachtingen komen tot stand op basis van subjectieve beoordelingen, interpretaties en voorspellingen. Richting - positief danwel negatief - en sterkte van deze verwachtingen bepalen of het individu al dan niet tot actie overgaat in de betreffende situatie; hoeveel energie hij wenst te investeren en hoe lang hij lets volhoudt. Negatieve en positieve verwachtingen kunnen elkaar vicleus versterken. De door Bandura ontwikkelde theorie is van toepassing op overt en covert gedrag. Bandura is van mening dat persoonlijke competentie-verwachtingen gebaseerd zijn op vier informatiebronnen, te we ten:

a. "performance accomplishments", dat wil zeggen daadwerkel ijk gebleken bekwaamheid wat het stellen van het doelgedrag betreft.

b. vicarlleuze ervaringen met het betreffende doellgedrag.

c. verbale overtuiging door ter zake deskundige anderen.

d. fysiologische gewarwordingen.

Bandura is bovendien van mening dat van deze vier informatiebronnen de eerste de meest invloedrijke is. Deze bevinding heeft gevolgen voor de psychotherapeutische praktijk. De auteur draagt een groot aantal empirische argumenten aan die de superioriteit van "performance based" 
procedures onderstrepen. De term "performance based" verwijst naar al die psychotherapeutische procedures en technieken die daadwerkelijke inoefening en "succesvolle" uitwoering van het doelgedrag door het individu nastreven. Door te postuleren dat verwachtingen van eigen competentie(s) in specifieke situaties uiteindelijk bepalend zijn voor het optreden van gedrag en dat deze verwachtingen primair gebaseerd zijn op eigen gedragservaringen, makt Bandura inzichtelijk dat gedragsverandering cognitieve veranderingen veronderstelt. Deze cognitieve veranderingen blijken bovendien het best gerealiseerd te kunnen worden met behulp van procedures die "performance accomplishments" bewerkstelligen.

De auteur is dan ook van mening dat men clienten tijdens psychotheraple in staat dient te stellen zelfstandig en effectief te functioneren in door hen als problematisch ervaren situaties. Daarbij is het van centraal belang dat men de betreffende clienten leert de aldus opgedane ervaringen cognitief te verwerken in termen van persoonlijke competentle, teneinde blijvende veranderingen tot stand te brengen in de beoordeling van het individu van zichzelf en zijn eigen mogelijkheden.

\subsubsection{Implicaties voor vaardigheidstherapieën}

Wit de "self-efficacy-theory" van Bandura kan men consequenties trekken wat betreft:

- opzet en uitvoering van de in dit proefschrift beschreven vaardigheids therapieën,

- de indicatie-stelling daartoe,

- mogelijke effectiviteitscriteria bij de evaluatie van de effecten daarvan.

Wat opzet en uitvoering van de vaardigheidstherapieën à la Goldstein betreft (zfe ook Beekers, 1982) kan men stellen dat Goldstein-therapeuten er - in navolging van Bandura - naar streven de persoonlijke competentie-verwachtingen van de deelnemers te versterken. Er wordt terdege rekening gehouden met Bandura's standpunt dat ervaringen met het daadwerkelifk stellen van de (nieuw) aan te leren vaardigheid de 
persoomlijke competentie-verwachtingen het sterkst beinvloeden. Programa-ontwikkeling en uitwoering van de vardigheidstherapieën zijin er immers op gericht het individu dat aan de vaardigheidstherapie deel neemt, in staat te stellen zoveel mogelijk positieve ervaringen op te doen met het stellen van de aan te leren vaardigheid: tijdens de groepsbijeenkomsten en in de eigen leefomgeving.

Conform Bandura's theorie dienen de therapeuten bij de uitvoering wan vaardigheidstherapieën een aantal maatregelen te nemen die de kans op verwerking van eigen ervaringen met het stellen van de betreffende vaardigheid in termen van persoonlijke competentie optimaliseren. Bandura geeft in dit kader de nu volgende grondregels weer:

1. de therapeuten dienen de deelnemers in staat te stellen door hen als problematisch ervaren situaties zo zelfstandig mogelijk te bemeesteren. Dit geldt voor de gedragsoefeningen tijdens de groepsbijeenkomsten en in de eigen leefsituatie. Algemeen geldt: hoe meer hulp en begeleiding deelnemers ervaren van de kant van de therapeuten, des te groter de kans dat men het bemeesteren van de betreffende situatie niet aan eigen inspanning toeschrijft en dus codeert in termen van een falende persoonlijke competentie.

2. de therapeuten dienen de oefensituaties, tijdens de groepsbijeenkomsten en bij de huiswerkopdrachten, zo te kiezen dat de dee1nemers deze zonder al te veel inspanning en met positief effect kunnen afhandelen. Algemeen geldt dat hoe meer inspanning het een deelnemer kost de betreffende vaardigheid met positief effect te stellen, des te geringer het effect van deze ervaring op de persoonlijke competentie-verwachting.

3. de therapeuten dienen de oefensituaties, tijdens de groepsbijeenkomsten en bij de huliswerkopdrachten, te kiezen volgens een gelefdelijk oplopende hiërarchie van moeilijkheidsgraad. Algemeen geldt hoe moeilijker de situatie die een individu zelfstandig en met positief resultat weet af te handelen, des te groter het effect daarvan op de persoonlijke competentie-verwachting.

4. de therapeuten dienen de oefensituaties, tijdens de groepsbijeenkomsten en bij de huiswerkopdrachten, zo te kiezen dat het aantal verschillende situaties dat de deelnemers met positief effect weten te bemeesteren, zo groot mogelijk is. Algemeen geldt: hoe groter 
het antal verschillende situaties dat een individu met positief effect weet te bemeesteren, des te sterker zal diens persoonlijke competentie-verwachting generalliseren.

Bif de in hoofdstuk 3 beschreven ultwoering van de persoonlijke vaardigheldstherapleën worden deze grondregels als leidraad gehanteerd.

Wat de indicatie-stelling betreft, kan men verwachten dat individuen die gekenmerkt worden door 1 age persoonlijke competentie-verwachtingen ten aanzien van de betreffende vaardigheid het meest van de hier beschreven vaardigheidstherapieën zullen profiteren. Ten aanzien van deze clienten is er sprake van een lage algemene persoonlijke competentie-waardering.

Wat de effectiviteitscriteria betreft, kan men concluderen dat het, gezlen de doelstellingen van de beschreven vaardigheidstherapieën, geboden 1ijkt naast beheersingsoriëntatie ook persoonlijke competentiewaardering als criterium in aanmerking te nemen bij het in hoofdstuk 7 te beschrijven effectiviteitsonderzoek.

\subsubsection{Het stressmode1 van Lazarus}

De persoonlijke en interpersoonlijke vaardigheidstherapieën à la Goldstein zijn erop gericht de deelmemers effectiever te leren omgaan met door hen als problematisch ervaren situaties. Men streeft ernaar de instrumentele copingfuncties van het individu te versterken. Het door Lazarus (1966) ontwikkelde stressmodel is een cognitief georiënteerd verk1aringsmodel met betrekking tot de wijze waarop individuen reageren op door hen als (be)dreigend en/of problematisch ervaren situaties.

Genoemd model is in tweeërlei opzicht relevant:

1. als theoretisch verklaringskader,

2. als hulpmiddel bij het bepalen van het toepassingsgebied van de in dit proefschrift beschreven vaardigheidstherapieën. 
In het nu volgende zal het door Lazarus ontwikkelde model worden behandeld, alsook de relevantie daarvan voor vaardigheidstherapieën.

\subsubsection{Beschrijuing van het model}

In het door Lazarus (1966) ontwikkelde stressmodel staan cognilteve processen centraa1. Met behulp van een aantal van deze processen eva1 ueert en interpreteert het individu als actieve informatie-verwerker alle op hem afkomende stimulf. Evaluatie van dergelijke stimuli in termen van (be)dreiging leidt tot stressreacties bij het individu. Deze stressreacties omvatten altijd een fysiologische en een psychologische component.

De fysiologische component betreft de lichamelijke sensaties waar het optreden van stress mee gepaard gaat. De psychologische component betreft de door het betreffende individu ervaren emoties. Lazarus is van mening dat emoties altijd worden voorafgegaan door een cognitieve activiteit in de vorm van een subjectief bepalde evaluatie van de betreffende stimulussituatie. Deze cognitieve activiteit wordt door Lazarus ook wel aangeduid als "appraisal". (Be)dreiging en appraisal vormen de kernbegrippen in de door Lazarus ontwikkelde theorie. Onder (be)dreiging verstaat men de verwachting van het individu dat hif in een bepaalde, specifiek omschreven situatie enige vorm van schade en/ of letsel ("harm") zal ondervinden. Deze schade betreft niet alleen direct warneembare vormen van lichamelijk letsel maar ook psychisch bepaalde vormen van beschadiging in de zin van blokkade van het bereiken van door het betreffende individu belangrijk geachte doelen. De beoordeling van een bepalde situatie nar mate van (beldreiging verloopt aan de hand van subjectieve matstaven en criterla en anticio peert op daadwerkelijke confrontatie met de betreffende situatie. Volgens Lazarus is deze anticipatie altijd (be)dreigender dan de feltelijke confrontatie (Mechanic, 1962; Stal, Scheffer, 1982).

Zoals reeds eerder werd gesteld, leidt het ervaren van (be)dreiging tot fysiologische zowel als psychische arousal-reacties. Deze arousalreacties leiden ertoe dat het betreffende individu pogingen gaat doen het verhoogde arousal-niveau, dat als een onaangename evenwichtsver- 
storing wordt ervaren, te verminderen. Dergelljke pogingen duidt men in de 11 teratuur aan met behulp van de tem copingwijzen. Lazarus maakt in dit opzicht een onderscheid tussen palliatieve en instrumentele wijzen van coping. Palliatlef betekent gericht op verzachting c.q. reductie van spanningsemoties met behulp wan afleidings- en ontspanningstechnieken. De term instrumenteel verwijst naar pogingen van het individu de problematische situatie direct te beinvioeden en te veranderen. Voor het effectief functioneren van een individu is het van belang dat hij belde soorten copingwijzen ter beschikking heeft. Wanneer een individu er niet in slaagt het, ten gevolge van het waarmemen van spanning, bij hem ontstane arousal-niveau te verminderen door toepassing van instrumentele, danwel palliatieve copingvormen kan dit op den duur aanleiding geven tot het ontstaan van (psycho)somatische problemen en ziekteprocessen.

Lazarus (1966) definieert coping als het totale spectrum van gedragsmatige, cognitieve en emotionele reacties die een bepaald individu beschikbaar heeft om ervaren (be)dreiging te reduceren of te elimineren. De auteur is van mening dat bij het copingproces 3 vormen van situatie- c.q. stimulusbeoordeling een rol spelen, te weten "primary appraisa1"; "secondary appraisal" en "reappraisal" "Primary appraisa1", ook wel aangeduid als primailre taxatie (Jaspers, 1980), betreft de eerste, anticipatoire beoordeling van een bepaalde situatie in termen, van (be) dreiging. "Primary appraisal" leidt enerzijds tot een eerste emotionele reactie van het individu op de betreffende (stimulus)situatie, anderzijds ook tot een eerste impuls tot handelen, namelijk aanvallen of wegviuchten. Is een bepaalde situatie eenmal als (be)dreigend geinterpreteerd door het individu, dan selecteert hij vervolgens strategieën met behulp waarvan hij het door hem geanticipeerde letsel of schade kan ellmineren of reduceren. Jaspers (1980) spreekt aver secundaire taxatie en onschrijft deze vorm van taxatie als de beoordeling van het vermogen tot coping.

"Reappraisal" of ook wel hertaxatie genoend, vloeit voort uit nileuwe informatie en/of reflectie over de eerdere perceptiels) $c . q$. feedback over het effect van de reacties van het individu.

De uitkomsten van de boven beschreven taxatie-processen vormen een functie van de kenmerken van de situatie enerzljds en de overtuigin- 


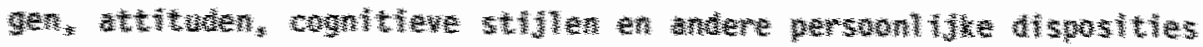

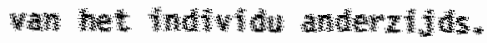

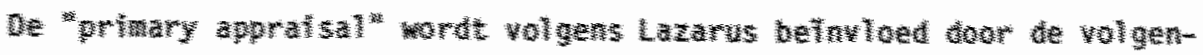
destaren:

- de wotrationele kenwerken wan het indwita;

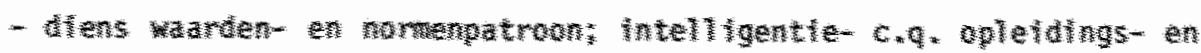

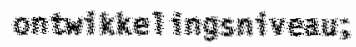

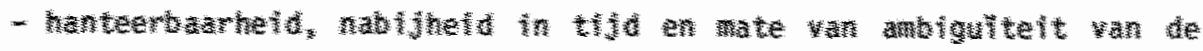

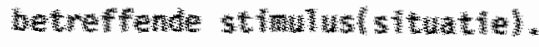

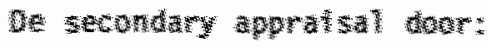

- He intensitelt van de srwarar lbeldrelging. warblj geldt dat een

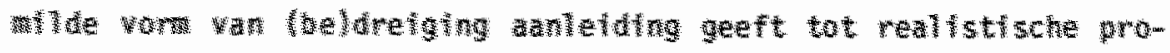
bianoplossmostratealean, extreme women to pathologische pro-

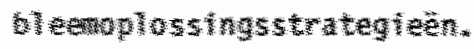

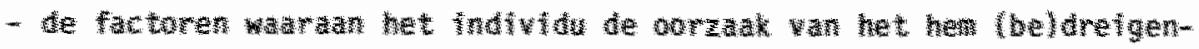

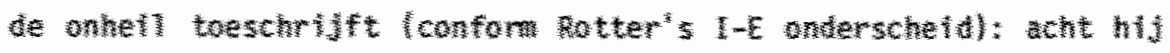

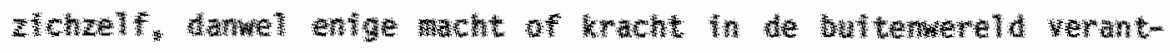

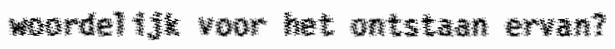

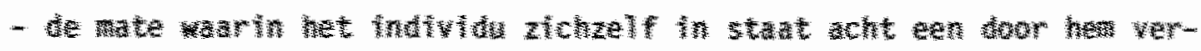

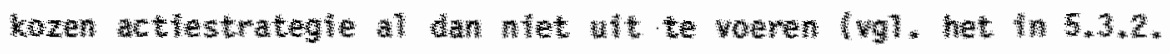

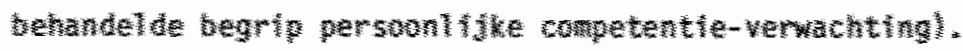

- 5uthanel bepertingen.

- wotwatione aspecten.

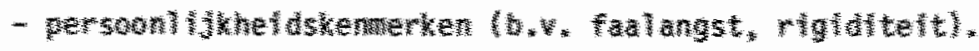

- wojel the dispostities tot defensibe reacties.

Lazarus doet geen uftspraken over de postileve of negatleve effecten van het ervaren van (be)dreiging op het prestatie-niveau van het individu. Hermans (1980) en Bremer (1983) zijn van mening dat het ervaren van enige mate van (be)dreiging positileve effecten kan hebben op het prestatie-niveau. Van dergelijke effecten blijkt sprake te zijn wanneer het individu het ervaren conflict niet als (be)dreiging maar als uitdaging interpreteert. Hermans (1980) spreekt in dit geval van positieve faalangst. Het eveneens door deze auteur ingevoerde begrip negatieve faalangst verwijst naar een mate van (be)dreiging die de prestaties van het betreffende individu belemmert. Het ervaren van 
[beldreiging zal veelal aanleiding geven tot defensieve reacties en vermijdingsgedrag; het ervaren van uitdaging tot het toepassen van doelgerichte probleenoplossingstrategieẻn.

\subsubsection{Relevantie ten aanzien van vaardighefdstherapieën}

Het model van Lazarus en de vaardigheidstherapieën à la Goldstein hebben belde betrekking op hetzelfde object, namelijk de wijze warop individuen reageren op door hen als problematisch ervaren situaties. Het mode 1 van Lazarus als theoretisch verk 1 aringsmodel, de vaardigheidstherapleën als therapievorm gericht op het aanleren van instrumentele copingvaardigheden voor het dagelijkse leven. Wat de hier beschreven vaardigheidstherapieën betreft, maakt dit model inzichtelijk dat men de deelnemers instrumentele copingstrategleën aanleert als antwoord op door hen als (be)dreigend ervaren (stimulus)situaties. De vaardigheidstherapieën zijn er immers op gericht individuen aan te zetten tot actief ingrijpen in door hen als problematisch ervaren (stimulus)situaties. Er wordt geen aandacht besteed aan het aanleren van palliatieve, op regulatie van emoties gerichte copingstrategieën. Bovenstaande maakt inzichtelijk dat deelname aan vaardigheidstherapieën versterking van een specifiek deelaspect van het copingrepertoire van het individu nastreeft, te weten versterking van instrumentele copingfuncties. Deelname aan deze vaardigheidstherapieën is dus aangewezen voor individuen met tekorten aan instrumentele copingvaardigheden. Individuen bij wie versterking van palliatieve functies wenselijk wordt geacht, komen dus niet voor deelname aan deze vorm van vaardighefdstherapleën in aanmerking. In het in hoofdstuk 7 beschreven onderzoek naar de effecten van persoonlijke vaardigheidstherapieën zal het concept instrumentele copingfunctie als een belangrijk effectiviteitscriterium in aanmerking worden genomen.

Lazarus' model maakt nogmaals duidelijk dat cognitieve verwerkingsprocessen een centrale rol spelen bij het tot stand komen van gedrag(sverandering). Wat de opzet en uitvoering van de beschreven vaardigheidstherapieên betreft, betekent dit dat de therapeuten expliciet aandacht moeten besteden aan het bevorderen van realistische apprai- 
sal-processen bij de deelnemers. Men dient erop toe te zien dat de deelnemers de eigen mogelijkheden en prestaties ten opzlichte wan door hen als (be)dreigend ervaren situaties realistisch waarnemen en cogmitief verwerken in termen van persoonlijke competentie en controle.

5.4. CONSTRUCTIE VAN EEN GEINTEGREERD COGNITIEF SOCIAAL-LEERTHEORETISCH MODEL

In figur 5.2. wordt een poging gedaan de door Bandura, Rotter en Lazarus ontworpen modellen te integreren.

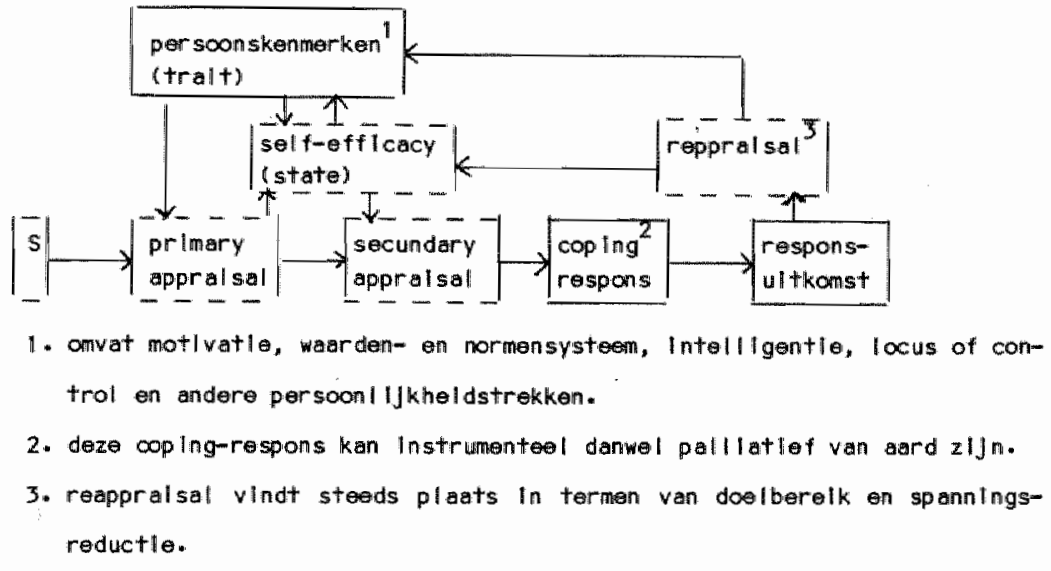

Figuur 5.2. Schematische wergave van gelntegreerd cognitlef soclaalleer theoretlsch model

Bij de constructie van bovenstaand model werd het stressmodel van Lazarus als uitgangspunt gehanteerd. De door Bandura en Rotter ontwikkelde concepten werden in dit model ingepast.

Wat de door Bandura ontwikkelde theorie betreft, geldt:

- dat de "self-efficacy" - of ook wel persoonlijke competentie-verwachting genoemd - van invloed is op de secundaire appraisal-processen en zodoende mede bepaalt of er een coping respons zal worden gesteld en zo $j a$, welke.

- dat "performance accomplishments" - in de zin van reappraisals van 
de situatie op grond yan de respons-uitkomst bij een bepaalde coping-respons - van invloed zijn op de sterkte van de "self-efficacy" en zodoende kwantiteit en kwaliteit van het gedrag van het individu in de toekomst mede bepalen.

Wat de door Rotter ontwikkeide theorie betreft, geldt:

- dat de "locus of control" van invloed is op de secundaire appraisalprocessen en zodoende mede bepaalt of er een copingrespons zall worden gesteld en $20 j a$, welke.

- dat de "1ocus of control" feedback ontvangt in de zin van informatie over (c.q. reappraisal van) de respons-uitkomst van een bepaalde coping-respons in termen van doelberelk c.q. persoonlijke controle.

Het fèlt dat de "7ocus of control" een "trait" vormt en de "self-efficacy" een "state", is in dit kader van ondergeschikt belang. De term "trait" betekent dat er sprake is van een redelijk stabiele, gegeneraliseerde eigenschap van de persoonlijkheid. De term "state" verwijst daarentegen naar een momentane toestand die de resultante vormt van de interactle tussen persoon en situatie op een bepald moment en van waaruit niet zonder meer gegeneraliseerd kan worden naar andere tijdstippen en situaties. "State" en "trait" eigenschappen zijn niet strijdig met elkaar maar vullen elkaar aan.

Bestudering van de door Rotter en Bandura ontwikkelde theorieën leidt tot de conclusie dat beide elkaar complementeren. In de theorie van Rotter ligt de nadruk op de uitwerking van het belang van het begrip reinforcement-waarde. In de theorie van Bandura ligt de nadruk op de uitwerking van het begrip persoonlijke competentie-verwachting. Het begrip respons-uitkomst verwachting wordt door laatstgenoemde auteur weliswaar genoemd maar niet nader uitgewerkt. De wijze waarop Rotter het begrip reinforcement-waarde uitwerkt, kan als een nadere operationalisering en concretlsering van het door Bandura gehanteerde begrip respons-uftkomst-verwachting worden opgevat.

Wat de door Lazarus ontwikkelde theorle betreft, geldt:

- dat deze theorle het belang van cognitieve beoordelingsprocessen bij het hanteren van als (be)dreigend ervaren situaties benadrukt. 
- dat deze theorie duidelijk makt dat de cognitieve beoordeling van een als (be)dreigend ervaren situatie in drie fasen verloopt.

- dat deze theorie duidelijk verenigbaar is met de theorieën van Rotter en Bandura.

Uit bovenstaand blijkt dat de door Bandura, Rotter en Lazarus geschetste modellen verenigbaar zijn met elkaar en elkaar aanvullen. Het eerder beschreven geintegreerde model stelt ons in staat de tijdens deelname aan vaardigheidstherapieën optredende leerprocessen afdoende te verklaren. Conform dit model dient er tijdens deze vaardigheidstherapieën naar gestreefd te worden dat:

- de persoonlijke competentie-verwachtingen van de deelnemers zoveel mogel ijk versterkt worden (conform Bandura).

- de respons-uitkomst-informatie bij de deelnemers geoptimaliseerd wordt (conform Rotter).

- de appraisal-processen, die in elke door het individu als (be)dreigend ervaren situatie een rol spelen, zo realistisch mogel ijk verlopen. Dit betekent dat men de kans op het optreden van verstoringen in het waarnemingsproces zoveel mogel ijk dient te minimaliseren door het verschaffen van objectieve feedback en informatie ten aanzien van persoon zowel als situatie.

5.5. DE UITVOERING VAN DE VAARDIGHEIDSTHERAPIEEN A LA GOLDSTEIN BESCHREVEN VANUIT EEN COGNITIEF SOCIAAL-LEERTHEORETISCH PERSPECTIEF

De wijzen warop de door Bandura, Rotter en Lazarus ontwikkel de theoretische concepten worden geoperationali seerd tijdens de groepsbijeenkomsten, zullen inmiddels voor een groot deel evident zijn. De complexe verwevenheid van deze principes in de diverse programma-onderdelen maakt het wenselijk de beschreven vaardfigheidstherapieën nog eens door te lichten aan de hand van de eerder weergegeven centrale theoretische concepten, te weten appraisal processen, persoonlijke competentie-verwachtingen en respons-uitkomst-verwachtingen. Appraisal processen zijn voortdurend gaande en spelen ten aanzien van elk onder- 
deel van de beschreven vaardigheidstherapieën een rol. Er worden geen maatregelen genomen, gericht op directe beïnloeding van de "primary appraisal" processen. Uitgaande van de veronderstelling dat de "primary appraisal" processen, indirect beinnioed worden door het aanleren van de leerpuntensequentie als adequat instrumenteel coping-alternatief in als (be)drelgend ervaren situaties. Wanneer de deelnemers in staat worden gesteld, tijdens de groepsbijeenkomsten en in de eigen leefsituatie, te ervaren dat het toepassen van de leerpuntensequentie de gevoelens van persoonlijke competentie en controle verhoogt, zal dat tot gevolg hebben dat de "primary appraisal" in toekomstige, soortgelljke (stimulus)situaties meer in termen van uitdaging en minder in termen van (be)dreiging zal plaatsvinden. "Primary appraisal" in termen van uitdaging verhoogt de kans op effectief functioneren in de betreffende (stimulus)situatie.

Persoonlijke competentie-verwachtingen en respons-uitkomst-verwachtingen zijn van invloed op de "secondary appraisal" processen. Deze verwachtingen tesamen bepalen of er al dan niet een instrumentele coping-respons zal worden gesteld door het individu in de betreffende (stimlus)situatie. In 5.5.1. worden de maatregelen beschreven die door vaardigheidstherapeuten worden genomen om de persoonlijke competentieverwachtingen van de deelnemers te verhogen en te doen generaliseren over meerdere (stimulus)situaties. In 5.5.2, worden de maatregelen beschreven, gericht op optimalisering van de respons-uitkomst-verwachtingen.

Persooni ijke competentie-verwachtingen en respons-uitkomst-verwachtingen worden in belangrijke mate bepaald door "reappraisal" processen ten aanzien van de eigen prestaties wat het toepassen van de leerpuntensequentie betreft. Door middel van deze "reappraisal" processen worden reeds aamwezige persoonlijke competentie-verwachtingen en respons-uitkomst-verwachtingen getoetst en bijgesteld. Dergelijke toetsing en bijstelling vindt plaats door middel van concrete informatie, feedback en positieve bekrachtiging ten aanzien van de eigen prestaties met betrekking tot de leerpuntensequentie. Tijdens de vaardigheidstherapieën 1 igt de nadruk op het verhogen en doen generalliseren van de persoonlijke competentie-verwachtingen van de deel- 
nemers en het optimaliseren van de respons-uitkomst-verwachtingen. Door bij het geven van informatie, feedback en bekrachtiging de nadruk te leggen op persoon 1ijke competentie en gedragseffectiviteit, wordt de "primary appraisal" in toenemende mate gekenmerkt door het ervaren van uitdaging in plaats van (be)dreiging; de "secondary apprailsal" door een toenemende mate van vertrouwen in eigen mogel ijkheden en komt bij de "reappraisal" de madruk te liggen op evaluatie van eigen prestaties in termen van doelbereik en persoonlijke competentie. Bovenstaande heeft tot gevolg dat de deelnemers aan de hier beschreven vaardigheidstherapieën in een positieve spiraal terecht komen, wat betreft de beoordeling van eigen competentie en effectiviteit in confrontatie met door hen als problematisch ervaren situaties. Een en ander leidt ertoe dat de betreffende leerpuntensequentie steeds vaker zal worden toegepast in soortgel ijke (stimulus)situaties.

5.5.1. Verhoging en generalisatie van de persoonlijke competentieverwachtingen

Verhoging van de persoonlijke competentie-verwachtingen wordt als volgt gerealiseerd door de therapeuten:

- vanaf de eerste zitting geven dezen er bij voortduring blijk van dat zij er alle vertrouwen in hebben dat de deelnemers de betreffende vaardigheid in de daartoe ter beschikking staande tijdspanne zullen leren beheersen.

- ze stellen de deelnemers in staat zoveel mogelijk oefening op te doen met de daadwerkelijke toepassing van de leerpuntensequentie tijdens de groepsbijeenkomsten en in de eigen leefsituatie.

- ze kiezen de oefensituaties zodanig dat er sprake is van een oplopende hiërarchile wat betreft moeilijkheidsgraad en dat faalervaringen zo veel mogel ijk worden voorkomen.

- ze streven ernaar de deelnemers elk van de eerder beschreven vormen van gedragsoefening (zie 3.2.2.) tifdens de groepsbijeenkomsten in toenemende mate van zelfstandigheid te laten doorlopen om zodoende de kans, dat men de kwaliteit van de eigen verrichtingen toeschrijft aan de veilige omstandigheden in de groep en/of aan de hulp en 
begelelding van de therapeuten, te minimalliseren en de kans, dat men elke ervaring kan toeschrijuen aan persoonlijke competentie, te optimalitseren.

- ze geven de deelnemers concrete en gedetailleerde feedback wat de uitvoering van de leerpuntensequentie betreft. Bij het geven van feedback ligt de nadruk op competenties en wordt zo min mogelijk aandacht besteed aan gedragstekorten. Verrichtingen conform de leerpuntensequentie worden expliciet positief bekrachtigd. Door middel van deze feedback en bekrachtiging stelt men de deelnemers in staat positieve verwachtingen te ontwikkelen wat de eigen mogelijkheden tot instrumentele coping betreft.

- ze stellen de deelnemers in de gelegenheld huiswerkervaringen die de persoonlijke competentfe-verwachtingen negatief beĩnvloeden, te herhalen tijdens de eerstvolgende groepsbijeenkomst en alsnog cognitief te verwerken in termen van persoonl ijke competentie en controle.

- ze zien erop toe dat de deelnemers negatieve ervaringen met de toepassing van de leerpuntensequentle die voortvioejen uit situatieve beperkingen ook cognitief in die zin verwerken en niet in termen van persoonlijk falen en te kort schieten.

Generalisatie van persoonlijke competentie-verwachtingen wordt alsvolgt gerealiseerd door de therapeuten:

- ze tonen de deelnemers videovoorbeelden van de toepassing van de leerpuntensequentfe die betrekking hebben op uiteenlopende stimulussituaties.

- ze kiezen de oefensituaties - tijdens de groepsbijeenkomsten en bij de huiswerkopdrachten - zodanig dat er sprake is van een gevarieerd aanbod wat betreft aard van de situatie alsook kenmerken en efgenschappen van eventueel aanwezige antagonisten.

5.5.2. Optimalisering van de respons-uitkomst-verwachtingen

Het optimaliseren van de respons-uitkomst-verwachtingen ten aanzien van de aan te leren vaardigheid gebeurt tijdens de gedragsoefeningen en tijdens de modeling. Een en ander wordt alsvolgt gerealiseerd: 
- men stelt de deelnemers in staat de effectiviteit van de betreffende vaardigheid te ervaren in de gedragsoefeningen tijdens de groepsbijeenkomsten en in de eigen leefongeving.

- men biedt de deelnemers videovoorbeelden aan warin toepassing van de betreffende leerpuntensequentie een positievere afloop bewerkstelligt dan de afwezigheid daarna.

- "video-autoriteit" en therapeuten dragen de opvatting uit dat het in praktijk brengen van de leerpuntensequentie de kans op effectieve afhandel ing van de betreffende situatie(s) optimaliseert.

- de deelnemers zijn getuige van toepassing(en) van de leerpuntensequentie met een positief effect door derden: tijdens de groepsbijeenkomsten en in de eigen leefsituatie.

- bij de nabespreking van huiswerkopdrachten en gedragsoefeningen wordt expliciet aandacht besteed aan de positieve effecten die toepassing van de leerpuntensequentie met zich meebrengt(-bracht). 
DEEL III. EMPIRISCH ONDERZOEK NAAR DE EFFECTEN VAN PERSOONLIJKE VAARDIGHEIDSTHERAPIEEN BIJ KANSARME GEESTELIJKE GEZONDHEIDSZORG CLIENTEN

HOOFDSTUK 6. ONTWIKKELING YAN EEN EVALUATIE-INSTRUMENT

\subsection{INLEIDING}

In hoofdstuk 5 werden een aantal algemene psychologische criteria besproken met behulp waarvan de effectiviteit van de in dit proefschrift beschreven persoonlijke vaardigheidstherapieën kan worden vastgesteld. Besloten werd naast deze meer algemene criteria ook een criterium te kjezen dat de doelstelingen van de persoonlijke vaardigheidstherapieën directer representeert. Op basis van een overzicht van elders verricht onderzoek kwam men tot de conclusie dat er momenteel geen pasklaar evaluatie-instrument voor handen was, direct afgestemd op de doelstellingen van de hier beschreven persoonlijke vaardigheidstherapleën.

Besloten werd een dergelijk instrument te ontwikkelen. In 6.3. wordt aandacht besteed aan de wijze waarop dit instrument tot stand kwam. In 6.4. wordt verslag gedaan van een onderzoek naar de psychometrische eigenschappen van dit instrument. Paragraaf 6.5 . omvat samenvatting en conclusies.

\subsection{LITERATUUROVERZICHT}

Besloten werd een literatuuronderzoek te doen teneinde na te gaan wat er aan effectiviteitscriterla voorhanden bleek. Daartoe werd een inventarisatie verricht van eerder en elders verricht onderzoek. De gerapporteerde studies hebben allen betrekking op de evaluatie van de effecten van trainings- c.q. therapieprogramma's gericht op het aanleren van "probleemoplassen" (zie tabel 6.1.), en van "beslissingen nemen" (zie tabel 6.2.). Wat "informatie verzamelen" betreft bleek 
geen effectiviteitsonderzoek voorhanden. Ten aanzien van "veranderingen aanpakken" geldt dat men in de literatuur wellswaar allerlei onderzoeken aantreft die betrekking hebben op verandering van eetgedrag, rookgedrag, type-A-gedrag etc. Deze onderzoeken zijn hier weinig relevant vanwege de specificiteit van de daarin nagestreefde gedragsverandering(en). Deze specificiteit heeft tot gevolg dat in de onderzoeksopzet alleen zeer specifieke meetinstrumenten in aanmerking worden genomen, zoals bijvoorbeeld die ter bepaling van calorie-intake, antal sigaretten per dag etc. Men treft geen meetinstrumenten aan die beogen vast te stellen of en in hoeverre deelnemers aan dergelijke programa's een strategie hebben aangeleerd met behulp warvan ze verandering tot stand kunnen brengen. De vardigheidstherapie "veranderingen aanpakken" is erop gericht deelnemers een dergelijke algemeen toepasbare veranderingsstrategie aan te leren. Dit impliceert dat een passend evaluatie-instrument het al dan niet aanwezig zijn van een dergelijke strategie dient te evalueren.

De tabellen 6.1, en 6.2. geven een overzicht van elders gehanteerde effectiviteitscriteria. Men kan constateren dat in de meeste studies algemene en meer specifieke critteria naast elkaar worden toegepast. Uit beide tabellen blijkt dat de verschillende studies het probleemoplos- danwel beslisproces op verschillende wijzen operationaliseren (zie ook 2.3.1. en 2.3.3.).

Tabel 6.1. Overzlcht ven effect Iw Iteltsonderzoeken betreffende "dagel IJkse problemen aenpakken ${ }^{\text {th }}$

\begin{tabular}{|c|c|}
\hline Auteurs & Evaluatlo-instrumenten \\
\hline $\begin{array}{l}\text { A11en, Chinsky, Larcen, } \\
\text { Lochman on Sollinger, } 1976\end{array}$ & $\begin{array}{l}\text { - schr Iftellike interpersoonl Ijke problem- } \\
\text { solving tests } \\
\text { - problen-solving gedragstest } \\
\text { - soclomatrl sche mat } \\
\text { - } \text {-E vragenlljst }\end{array}$ \\
\hline Arnkoff en stowart, 1975 & - mondel Ings problemoplastest \\
\hline $\begin{array}{l}\text { Bedell. Areher en Marlow Jr., } \\
1980\end{array}$ & 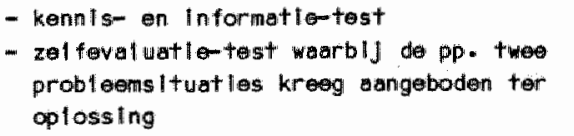 \\
\hline
\end{tabular}


- de Minlawult (KIncaninon, 1966)

Coché en Douglas, 1977

- Weans Ends Problem Solving test

- Mapi

- de Mnlmult (KIncannon, 1966)

- adjectlive checkll st

Edelsteln, Couture, Cray, Dlckens en Lusebrink, 1980

Holl ander, 1980

Hollender, 1980
- elke delmener kreeg 4 probleensituatles ter oplassing

- gedragstest problemoplassen

- schrlltellike motivatletest

- een schrlftel ljke tevredenheldstert

- de MEPS
- de Purdue problem solving Inventory

- en specilall voor dit onderzoek geconstrueerde schrlftellike transfertest

\begin{tabular}{|c|c|}
\hline Intag I lata, 1978 & $\begin{array}{l}\text { - MEPS } \\
\text { - gestructureerd Interview } \\
\text { - soc liafie competentlemaat }\end{array}$ \\
\hline Jaicobison, 1977 & 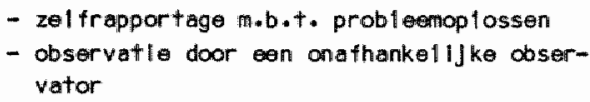 \\
\hline
\end{tabular}

$\begin{aligned} \text { Jacobison, } 1979 & - \text { observatle opdrachten } \\ & - \text { abservatle door en on fhankellyke obser- } \\ & \text { vator }\end{aligned}$

Jacobson en Anderson, 1980

- observatlles door onathankell IJke observa toran

Klarrelch, 1975

- Tennessee seif concept scalle

- Fundamental Relations or lentation Behavlour ( $F \mid R O-B$ )

- Life Skllis Problem Checkllst

$\begin{aligned} \text { Lorlsh, } 1974 \quad & - \text { Kohlberg Moral Judgement Pratacols } \\ & \text { - Carkhuff Empathy Scales } \\ & \text { - Crites Caroer Matur Ity Inventory }\end{aligned}$

Mayo on Nortion, $1980 \quad$ - schrliftell llke zelfrapportage

Mendonca en Sless, 1976

- Imaginalr rolltenspel met behulp van taperecorder

- decision difficulty checkll Ist

\begin{tabular}{|c|c|}
\hline Moyers, 1978 & $\begin{array}{l}\text { - soclalle angst schaal } \\
\text { - negatleve zel feval watl le-schaal } \\
\text { - gedragsbeoor del lings } 1 \text { iljst } \\
\text { - soclometr Ische maat } \\
\text { - gedregsmat }\end{array}$ \\
\hline
\end{tabular}




\begin{tabular}{|c|c|}
\hline Poltras-Martin an stone, 1977 & $\begin{array}{l}\text { - schrlftelljke problemoplostoets ad hoo } \\
\text { ontulkkeld }\end{array}$ \\
\hline Rlchards en Perrl, 1978 & 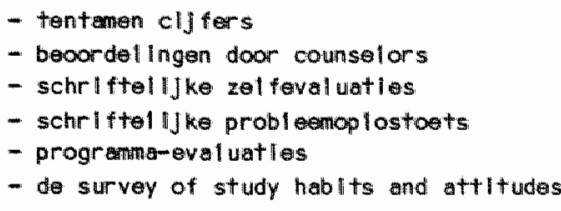 \\
\hline $\begin{array}{l}\text { Roblin, Kent, onLeary, Foster, } \\
\text { en Primz, } 1977\end{array}$ & $\begin{array}{l}\text { - zell-observat les } \\
\text { - cormun lcatle check I Ist } \\
\text { - beoordel Ingen door abservatoren }\end{array}$ \\
\hline Sllegell en Splvack, 1976 & $\begin{array}{l}\text { - Interpersoonl IJ ke probleamoplas vragen- } \\
\text { llJ sten } \\
\text { - Matching Fanil I Iar Flgures test (KKagan } \\
\text { l965) } \\
\text { - MEPS }\end{array}$ \\
\hline Splwack, Platt, en Shure, 1976 & $\begin{array}{l}\text { - MEPS } \\
\text { - gedragsmaat voor soc lalo aanpass Img }\end{array}$ \\
\hline
\end{tabular}

Tabel 6.1. 1 eidt tot de volgende constateringen:

1. ten aanzien van de in de aangehaalde onderzoeken gehanteerde effectiveitscriteria geldt dat er geen sprake is van een of meerdere evaluatie-instrumenten die algemeen gebruikelijk zijn. De variatie in toegepaste meetinstrumenten is erg groot.

2 . in een groot aantal onderzoeken wordt een combinatie van schriftelijke evaluatie-instrumenten en directe gedragsobservaties toegepast.

3. ten aanzien van schriftelijke evaluatie-criteria en gedragsobservaties geldt dat vrijwel elke onderzoeker deze op elgen wijze inhoud geeft en operationaliseert. Er blijkt weinig overeenstemming te bestaan over in dit kader relevante algemene psychologische dimensies en gedragscriteria.

Deze constateringen blijken ook van toepassing te zijn op de in tabel 6.2. beschreven effectiviteitsonderzoeken ten aanzien van "besilssingen nemen". 
Tabel 6.2. Overzlcht van effectiviteitsstudies ton anzlan van meslissingen namern in alfiobetischo volgorde van uteurs

\begin{tabular}{|c|c|}
\hline Mutreiurs & Eval uet lie- Instrunenten \\
\hline $\begin{array}{l}\text { Bergl and: Quatrario on Lund- } \\
\text { quilst, } 1975\end{array}$ & $\begin{array}{l}\text { - attltude questionnalr } \\
\text { - wocatlonal information survey } \\
\text { - Carraer Pli anning linwentory } \\
\text { - Voc ational planning questlonnalre }\end{array}$ \\
\hline Evans on Cody. 1969 & $\begin{array}{l}\text { - gedragstest plus onathamkal ljke beoorde- } \\
\text { laars }\end{array}$ \\
\hline Russell on Thoresen, 1976 & 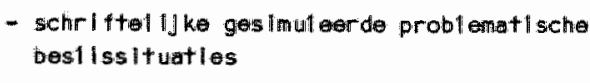 \\
\hline $\begin{array}{l}\text { Waliace, Horan, Baker en } \\
\text { Hudson, 1975 }\end{array}$ & $\begin{array}{l}\text { - op cassetterecorder opgenomen probleme- } \\
\text { +1sche buesillssituatles }\end{array}$ \\
\hline
\end{tabular}

Op basis van tabe1 6.1. en 6.2. kan men constateren dat er weinig concensus bestaat ten aanzien van het in dit kader te hanteren evaluatieinstrumentarium.

Wat de meer algemene effectiviteitscriteria betreft, is sprake van een bonte verzameling evaluatie-instrumenten die allen uiteenlopende aspecten van de persoonlijkheid operationaliseren. De in hoofdstuk 5 beschreven algemene theoretische verklaringsmodellen relevant in relatie tot de in dit proefschrift beschreven persoonlijke vaardigheidstherapieën, vormen een hulpmiddel bij het uitselecteren van die evaluatieinstrumenten die in dit kader van belang $z i j n$. Op basis van voornoemde modellen besloot men beheersingsoriëntatie, persoonlijke competentieverwachting(en) en instrumentele copingfuncties als effectiviteitscriteria in aanmerking te nemen (zie hoofdstuk 7 ).

Wat de specifieke criteria betreft, kan men eveneens weinig onderinge consensus constateren. Ook in het Nederlands taalgebied is geen eenvoudig afneembaar, kort en overzichtelijk meetinstrument voor handen met behulp warvan men de specifieke doelstellingen van de beschreven vaardigheidstherapleën directer en speciffeker zou kunnen toetsen. Dit stelt ons voor de taak wat dit betreft een eigen evaluatie-instrument te ontwikkelen. Bedoeld evaluatie-instrument dient het constructpersoonlijke (on)vaardigheid adequat te operationaliseren. Een con- 
struct dat nader gedefinieerd kan worden als het vermiogen effectief te reageren in problematische situaties, en wel in die zin dat men in dergelijke situaties primair handelt op basis van mationele overwegingen en principes. Besloten werd een evaluatie-instrument te ontwikkelen in de vorm van een schriftelijke vragenlijst en niet in de vorm van een of meerdere gedragsobservaties. Men gaf de voorkeur aan ontwikkeling van een evaluatie-instrument in de vorm van een schrifte1ijke vragenlijst omdat bestudering van literatuur relevant in relatie tot gedragsobservatie(s) als evaluatie-instrument tot de conclusie leidde dat constructie, inhoudsvalidering en betrouwbarheidsbepaling met betrekking tot gedragsobservatie(s) problemen oplevert, waar vooralsnog geen adequate standaard-oplossingen voor voorhanden zijn (Lipinsky en Nelson, 1974; McFal1, 1977; Bellack, Hersen, Turner, 1978; Bellack, Hersen, Lamparski, 1979; Higgins, Alonso, Pendleton, 1979; McFall en Marston, 1980; Van Hasselt, Hersen en Bellack, 1981). Het feit dat tijdens de in dit proefschrift beschreven persoonifjke vaardigheidstherapieën de nadruk wordt gelegd op het aanleren van coverte gedragsaspecten c.q. denkstappen, blijkt de constructie van een directe vaardigheidstoets en/of anderssoortige gedragsobservaties als evaluatie-instrument nog eens extra te bemoeilijken. In tegenstelling tot overt gedrag wordt covert gedrag gekenmerkt door het feit dat dit niet direct warneembaar is, en veelal alleen indirect kan worden waargenomen. Dit heeft gevolgen woor de meetbaarheid ervan. Naast de hierboven weergegeven inhoudelijke argumenten, speelden de nu volgende pragmatische overwegingen een rol bij de keuze voor de constructie van een schriftelijke vragenlijst als evaluatie-instrument. De constructie van een directe vaardigheidstoets en/of anderssoortige vorm van gedragsobservatie vereist meer mankracht en financiele middelen dan de constructie van een schriftelijke vragenlijst.

op basis van bovenstaande overwegingen - zowel inhoudelijk als pragmatisch van aard - besloot men een aangepast evaluatie-instrument te ontwikkelen in de vorm van een schriftelijke vragenlijst. Deze vragenlijst dient qua taalgebruik te worden aangepast aan het taalgebruik van de LIBO-doelgroep. De ontwikkeling van deze lijst zal in het nu volgende warden beschreven. 


\subsection{CONSTRUCTIE VAN DE ITEMS}

De ontwikkeling van de vragenlijst bedoeld ter operationalisatie van het construct "persoonlijke (on)vaardigheid" werd gestart met het aanleggen van een pool items representatief voor het beoogde construct. Deze items werden gegenereerd door twee psychologen, bekend met inhoud en doelstelling(en) van de persoonlijke vaardigheidstherapieën. Aldus ontstond een vragenlijst van 33 items die de $D H-1$ ijst werd genoemd. $D H$ vormt de afkorting voor Doelmatig Handelen.

Gefnspireerd door Shapiro (1961) en conform de constructie van de interpersoonlijke vaardigheidsmeters (Beekers, 1982) werden per ontworpen $i$ tem drie antwoordmogelijkheden vastgesteld, namelijk een zogenaande "ziek" uitspraak, een "half beter" en een "beter" witspraak.

Voorbee 1d:
Als ik moet kiezen, $z$ it ik:
0 meestal te lang te wikken en te wegen
0 regelmatig te lang te wikken en te wegen
0 vrijwel nooit te 1 ang te wikken en te wegen

De eerste 24 items van de DH-1ijst werden allen op de hier besproken wijze vastgesteld. Vanwege het felt dat cognities veelal in de vorm van definitieve stellingen worden geponeerd, werden de items $25 \mathrm{t} / \mathrm{m} 33$ weergegeven in de vorm van stellige uitspraken met als antwoordmoge1ijkheden: "waar", "enigszins waar" en "niet waar" zoals bijvoorbeeld:

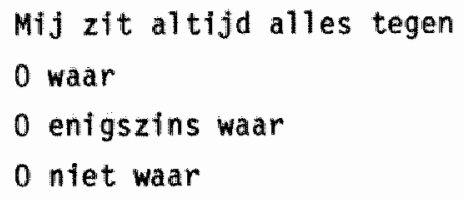

Voor een overzicht van de aldus geconstrueerde vragenlijst zie bijlage III. 
6.4. OPZET VAN HET ONDERZOEK NAAR DE PSYCHOMETRISCHE EIGENSCHAPPEN VAM DE DH-LIJST

In het nu volgende wordt een onderzoek beschreven naar de psychometrische eigenschappen van de in 6.3. beschreven DH-1ijst. In 6.4 .1 . worden proefgroep en procedure beschreven. In 6.4.2. Worden de resultaten van de in ditt kader ultgevoerde factor-analyse besproken. Verwolgens wordt aandacht besteed aan de betrouwbaarheid en stabiliteit van de 3 subschalen war de DH-lijst uit blijkt opgebouwd. Tot slot wordt verslag gedaan van onderzoek naar de divergerende valliditeit van de ontwikkelde vragentijst.

\subsubsection{Proefgroep en procedure}

Een groep van 2000 mannen en vrouwen, variërend in leeftijd van 25-55 jaar, aselect getrokken uit het bevolkingsarchief van de gemeente Maastricht, werd aangeschreven met het verzoek hun medewerking te willen verlenen aan door de capaciteitsgroep Medische Psychologie van de Rijksuniversiteit Limburg te verrichten onderzoek. Dit verzoek on medewerking ging vergezeld van een voorgefrankeerde antwoordkaart waarop de betreffende persoon kon aankruisen of $h i j / z i j$ al dan niet wenste mee te doen aan dit onderzoek.

498 Mensen vulden deze antwoordkaart bevestigend in en stuurden haar aan onderzoekster retour. Deze groep bestond uit 237 mamnen en 261 vrouwen. De leeftijdscategorie 25-55 jaar werd gekozen vanwege het feit dat de deelnemers aan Goldsteintherapieën grotendeels binnen deze leeftijdscategorte kunnen worden ondergebracht.

De DH-1 ijst werd per post toegezonden aan deze 498 proefpersonen. Van deze 498 proefpersonen stuurden er 377 de vragenlijst ingevuld en wel retour.

In bijlage IV wordt een overzicht gegeven van de uiteindelijk resterende groep van 377 proefpersonen in termen van sexe, leeftijd, burgerlijke staat, werksituatie en opleidingsniveau.

Door de afdeling bevolking van de Gemeente Masitricht wordt alleen informatie verschaft ten aanzien van de variabelen sexe en leeftiJd. 
Op de varlabelen burgelfjke stat, werksituatie en opleidingsniveau rust een embarga op basts van privacy-overwegingen.

De oorspronkelijke steekproef van 2000 Mastrichtenaren bestond uit 1000 mannen $(=50 \%)$ en 1000 vrouwen $(=50 \%)$. Van de vrouwen waren 438 personen $\geq 25$ jaar en $<35$ jaar $(=43.8 \%)$; 278 personen $\geq 35$ jaar en $<$ 45 jaar $(=27.9 \%)$ en 284 personen $\geq 45$ jaar en $<55$ jaar $(=28.4 \%)$. Van de mannen waren 402 personer $\geq 25$ jaar en $<35$ jaar $(=40.2 \%) ; 326$ personen $\geq 35 \mathrm{jaar}$ en $<45 \mathrm{jaar}(=32.6 \%)$ en 272 personen $\geq 45$ jaar en <55 Jaar $(=27.2 \%)$.

Vergelifking met de in bijlage IV beschreven proefgroep, leidt tot de concluste dat de verdeling naar sexe en leeftijd in de oorspronkel ijke steekproef over de gehele lijn genomen overeenstemt met de verdeling van deze varlabelen in de uiteindelijke proefgroep.

Binnen de oorspronkelijke steekproef van 2000 proefpersonen kan niet worden nagegaan in welke opzichten de $25 \%$ die zich bereld verklaarde aan $d t$ onderzoek mee te doen, overeenkomen met c.q. verschillen van de $75 \%$ dle niet wenstte mee te werken. Deze gedwongen leemte in de karakterlsering van de proefgroep heeft uiteraard gevolgen voor de generallseerbaarheid van de gevonden resultaten.

In de proefgroep blijken ongeveer evenveel vrouwen als mamen opgenomen. Voor belde subgroepen geldt dat alle opleidingsniveau's in de proefgroep vertegenwoordigd $z i j n$. Conform algemene bevolkingsgegevens blijkt het aantal mannen in het hoogste opleidingsniveau groter dan het aantal vrouwen daarin.

Wat leeftijdsopbouw betreft, blijkt de groep mannen vrijwel identiek aan de groep urouwen. Het aantal ongehuwde mannen blijkt groter dan het aanta ongehuwde vrouwen.

Het aantal miet-werkende vrouwen blijkt beduidend groter dan het aantal niet-werkende mannen. De categorie niet-werkende vrouwen omvat al die vrouwen die geen betaalde baan buitenshuis hebben.

\subsubsection{Resultaten factor-analyse}

Teneinde te kunnen bepalen uit welke factoren de geconstrueerde vragenlijst was opgebouwd besloot men een principale factoren-analyse uit 
te voeren over het conform 6.4.1. verkregen databestand. Uit dit databestand werden die items van de $\mathrm{DH}-1 \mathrm{ijst}$ verwijderd, waarbij meer dan 70\% van de antwoorden in een van de beide extreme antwoordcategorleën viel, aangezien het discriminerend vermogen van het betreffende item daardoor te zeer te niet werd gedaan (14 items). Over de resterende 19 items werd een principale factoren-analyse uitgevoerd. Bij de interpretatie van de gegevens uit deze factor-analyse werden alleen die items in aanmerking genomen met factorladingen $\geq 0,30$. De 19 items bleken allen aan deze voorwaarde te voldoen. Varimaxrotatie leidde tot de conclusie dat een 3-factoren oplossing het best op het beschreven data-bestand bleek te passen.

\begin{tabular}{|c|c|c|c|}
\hline Item factor & $F_{1}$ & $\mathrm{~F}_{2}$ & $F_{3}$ \\
\hline 1 & 0.61 & -0.04 & -0.02 \\
\hline 2 & 0.49 & -0.03 & -0.16 \\
\hline 3 & 0.50 & -0.0 .4 & -0.12 \\
\hline 4 & 0.59 & 0.06 & -0.18 \\
\hline 5 & 0.73 & 0.00 & -0.12 \\
\hline 6 & 0.69 & -0.15 & -0.08 \\
\hline 7 & $\overline{0.66}$ & -0.03 & -0.15 \\
\hline a & 0.46 & -0.08 & -0.25 \\
\hline 9 & $-\overline{0.12}$ & 0.64 & 0.14 \\
\hline 10 & -0.03 & 0.55 & 0.12 \\
\hline 11 & -0.08 & $\overline{0.48}$ & 0.15 \\
\hline 12 & -0.01 & 0.42 & 0.20 \\
\hline 13 & 0.08 & 0.68 & 0.01 \\
\hline 14 & -0.17 & 0.13 & 0.47 \\
\hline 15 & -0.07 & 0.06 & 0.48 \\
\hline 16 & -0.15 & 0.18 & 0.43 \\
\hline 17 & -0.19 & 0.25 & 0.50 \\
\hline 18 & $-5.0 \mathrm{~s}$ & 0.08 & 0.36 \\
\hline 19 & -0.25 & 0.0 & 0.35 \\
\hline E & 4 & 2.40 & 3.39 \\
\hline Narklorder war & $23=1$ & 12.64 & 7.34 \\
\hline
\end{tabular}

op grond van inhoudel thche bevindingen ut tabel 6.3 . werd de on-115t apgedecld in 3 subschalen met respectievel $5 k 8,5$ en 6 tems. In het nu volgende $z$ ullen deze subchalen elk afzonderlikk worden besproken en van een passende benaming worden voorzlen. 
6.4.2.1. DH-subschaal 1: "Vertrouwen in eigen probleemoplossingsvaardigheid"

Subschaal 1 omvat de volgende 8 items:

1. Door tegenslag lat is mil wolledig/wel wat/vrlJwel inlot ult het weld sllan.

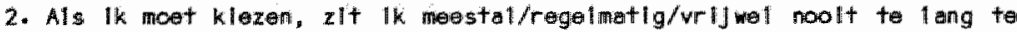
whlken en to wegen.

3. Problemen zlJn mo vrll well altljd/soms/wrljwel noolt de bas.

4. Als er pen probleem is, zle lk daar vilJwel altlJd/soms/vrljwel moolt tagknopi

5. Door problenen lat $1 \mathrm{~km} / \mathrm{m}$ vark/sons/blJ na noolt ontmoedigen.

6. Als or problemen zlJh, ben lk mergens meer: war/enlgszins war/miet war.

7. Ik $z l+$ gauw blj de pakken noer: war/enlgsalins warlinlot war.

B. Ik k win goed knopen doorhakken: war/enlgszlns wasr/nlet waar.

De items van subschaal 1 hebben betrekking zowel op "problemen aanpakken" als op "beslisingen nemen" (item 2 en 8 ). Ze betreffen de houding van het individu ten aanzien van beslissingen/prablemen. Alje items dragen de trekken van een sterk-zwak continuïm: problemen/beslissingen zijn mij de baas versus ik ben problemen/beslissingen de baas. De score op deze subschaal kan variëren van 0 (=minimumscore) tot 16 (=maximumscore). Een score van 0 betekent dat het betreffende individu weinig of geen vertrouwen heeft in zijn eigen probleemoplossings- c.q. besluitvaardigheld. Een score van 16 betekent dat het individu wel degel ijk vertrouwen heeft in eigen probleemoplossings- c.q. besluitvaardigheid.

6.4.2.2. DH-subschaal 2: "P1annen maken en vooruit demken"

Subschaal 2 omvat de volgende 5 items:

1. Plamnen maken vlind lk nuttlg/vind ik nlet zo erg nuttlg/vlnd lk halemaal nlet nuttlg.

2. Itk maak veak/soms/vr IJ wel noolt plannen.

3. Ik denk vaak/soms/bIJ na noolt na woordat lk orgens an begln.

4. Als Ik aun lets moollijks begin, bedenk lk meestal/soms/bljne noolt vooraf hoe $\mathrm{ik}$ het ga manpakken.

5. Ik denk vak/sons/buljnia nooitt voorult. 
De items van subschaal 2 hebben met elkaar gemeenschapperijk dat ze betrekking hebben op de mate van wooruitdenken c.q. plannen. De maximunscore $(=10)$ betekent dat de betreffende persoon zichzelf als een vooruitdenkend en weldoordacht individu beoordeelt. De mimumscore $(=0)$ houdt een ontkenning van deze beoordeling in.

\subsubsection{DH-subschaal 3: "Consequent handelen"}

Subschat 3 omvat de volgende 5 items:

1. Als lets me nlet bevalt, dan doe lk dear vrljwel altijd/sons/vr fjwel noolt lats an.

2. Als lk lets moet weten, zorg ik meestallwaak/wrlywel noolt dat ik or ook achter kom.

3. Wan mljn goede voornemens komt wrligel noolt/zo nu en dan wel/vrljwel altuju lets terecht.

4. Als lk lets van plan ben, dan doe lik daar mestal/soms/elgenllyk noott lets arti.

5. Als 4 k

6. 11 like dingen stel lk vrljwel altijdisoms/vrljwel noalt ult.

De items van subschaal 3 hebben allen betrekking op de mate warin het individu eenmal gemaakte voornemens ook daadwerkel ijk reallseert c.q. doorzet. In totaliteit lijkt deze schaal betrekking te hebben op de mate van handelend optreden van een individu ten aanzien vam als problematisch ervaren situaties. De maximumscore $(=12)$ betekent dat het betreffende individu zichzelf als een doorzetter en aanpakker beoordeelt. De minimumscore $(=0)$ betekent dat de betreffende persoon zichzelf ervart als lemand die snel opgeeft $c . q$. bij de pakken neer gaat zitten.

Samenvattend kan men de bij factoranalyse van de DH-lijst gevonden drie factoren karakteriseren a1s:

I. Vertrouwen in efigen probleemoplossingsvaardigheid

II. Plannen maken en vooruit denken

111. Consequent handelen 
Vervolgens besloot men de betrouwbarheid en stabiliteit wan de in 6.4.2. beschreven subschalen te bepalen. Voor elk van de 3 subschalen werd de betrouwbaarheid bepaald met behulp van Cronbach"s alpha: een veelvuldig gehanteerde coëfficient yoor itemconsistentie. Cronbach's a)pha's werden berekend over de totale groep van 377 proefpersonen zoals beschreven in bijlage IV. De alpha's varieren van 0.61 tot 0.82 .

Tabel 6.4. Interne consistentle (Cronbach"s alpha) en test-hertestcorrelatles (Pearson) over ean Interval van 12 maanden.

\begin{tabular}{|c|c|c|c|c|}
\hline DHt subschal on & 1. & 2. & 3. & $N$ \\
\hline $\begin{array}{l}\text { Botrou- } \\
\text { baerhelds- } \\
\text { coefflc lentem }\end{array}$ & & & & \\
\hline Cronbach"s lpha & 0.82 & 0.70 & 0.61 & 377 \\
\hline $\begin{array}{l}\text { Poar son-corirela- } \\
\text { tlos na } 12 \text { manden }\end{array}$ & 0.74 & 0.68 & 0.63 & 134 \\
\hline
\end{tabular}

In tabel 6.4. zijjn tevens de test-hertest-correlaties na 12 maanden opgenomen. Uit de in bijlage IV beschreven proefgroep van 377 proefpersonen werd een 0.5 sample getrokken ten behoeve van de test-hertest bepaling. 193 proefpersonen kregen de $\mathrm{DH}-1$ ijst nogmaals ter invulling toegestuurd na verloop van een jaar. Van de 193 proefpersonen stuurden er 134 de $\mathrm{DH}-1$ ijst ingevuld en wel retour.

Bif de test-hertest gegevens is overigens niet alleen de betrouwbaarheld van het gehanteerde meetinstrument aan de orde maar ook de stabi1 itelt van het meetobject. De Pearson-correlaties tussen beide meetmomenten variëren tussen 0.63 en 0.74 . Qua betrouwbaarheid maar aok qua stabilitelt blijken de $\mathrm{DH}$-subschalen derhalve acceptabel. DH-subschaal 3 "consequent handelen" is in deze de relatief zwakste schaal. 
6.4.4. Correlaties tussen de drie DH-subschalen onderling

Teneinde na te gaan of de ontwikkelde schalen onderling voldoende onafhankelijk zijn, werden de Pearsoncorrelaties bepaald tussen de 3 subschalen onderling (zie tabel 6.5.). De berekeningen werden uitgevoerd over de in bijlage IV beschreven groep van 377 proefpersonen.

Tabel 6.5. Correllaties tussen de 3 DH-subschal an onder IIrig

\begin{tabular}{|c|c|c|c|c|c|}
\hline Correlat le & $\mathrm{OH}$, & $\mathrm{DH}_{2}$ & : & 0.12 & nliat slgnil lcant \\
\hline Correlatle & $\mathrm{DH}_{2}$ en & $\mathrm{DH}_{3}^{2}$ & : & 0.31 & slgmifleant \\
\hline Correlatle & $\mathrm{OH}_{1}^{2}$ en & $\mathrm{DH}_{3}^{3}$ & : & 0.37 & sligrificant \\
\hline
\end{tabular}

Interpretatie van de in tabel 6.5. gepresenteerde correlatie-coëfficienten leidt tot de conclusie dat:

- "vertrouwen in eigen probleemoplossingsvaardigheid" $\left(\mathrm{OH}_{1}\right)$ en "plannen maken en vooruit denken" $\left(\mathrm{DH}_{2}\right)$ niet significant aan elkaar gerelateerd zijn,

- "plannen maken en vooruit denken" $\left(\mathrm{DH}_{2}\right)$ significant correleert met "consequent handelen" $\left(\mathrm{DH}_{3}\right)$ en wel in de zin van: hoe meer men voorwit denkt des te consequenter zal men ook handelen,

- "vertrouwen in eigen probleemoplossingsvaardigheid" $\left(\mathrm{DH}_{1}\right)$ significant correleert met "consequent handelen" $\left(\mathrm{DH}_{3}\right)$ en wel in de zin van: hoe meer "vertrouwen in elgen probleemoplossingsvaardigheid" des te consequenter zal men ook handelen.

\subsubsection{Bepaling van de divergerende validiteit}

Teneinde na te gaan of de 3 subschalen waaruit de DH-1ijst blijkt opgebouwd, eigenstandige aspecten van persoonlijke (onlvaardigheid operationaliseren, werd besloten een onderzoek te doen naar de divergerende validiteit van de 3 subschalen. Doel van dit onderzoek was na te gaan in hoeverre de 3 subschalen iets meer c.q. iets anders meten dan een vijftal bestaande psychologische vragenlijsten die inhoudelijk verwante constructen beogen te meten Deze verwante constructen $z i j n$ :

- beheersingsoriëntatie 
- copingstij1

- zelfwaardering

- rigiditeit

- neuroticisme

Dit zijn vijf algemeen theoretische constructen, relevant in relatie tot de hier besproken persoontijke vaardigheidstherapieën. In hoofdstuk 5 werd reeds aangegeven waarom de constructen beheersingsoriëntatie, zelfwardering en (instrumentele) copingstijl(en) in dit kader van belang zijn.

De constructen rigiditeit en neuroticisme worden in aanmerking genomen teneinde te kunnen bepalen in hoeverre de geconstrueerde vragenlijst "Doelmatig handelen" algemeen neurotische tendenzen en rigiditeit meet.

Deze constructen werden geoperationaliseerd met behulp van de nu volgende schriftelijke vragentijsten:

a. de Rigiditeitsschaal (RG) ult de NPV (Luteijn, 1974),

b. de Utrechtse Coping Lijst (UCL) (Schreurs e.a., 1984),

c. de Delftse Vragenlijst (DV): een neuroticisme-schaal ontwikkeld door Appels $(1974,1975)$,

d. de interne en externe locus of control schaal conform Emmelkamp (1975),

e. de zelfwaarderings (selfesteem) schaal (SE), ontwikkeld door Rosenberg (1965) en in het Nederlands bewerkt door Sanders (1977).

Deze vragenlijsten zullen in het nu volgende elk afzonderlijk kort worden toegelicht.

ad.a. De rigiditeitsschal (RG-schaal) wit de Nederlandse Persoons Vragenlijst (NPV; Luteijn, 1974) heeft betrekking op het planmatig (willen) laten veriopen van gebeurtenissen volgens vaste gewoontes en principes.

Voor meer informatie ten aanzien van de psychometrische eigenschappen van de RG-schal zie Luteijn (1974). Betrouwbarheidsanalyse en factoranalyse van de scores van de 377 cases zoals beschreven in bijlage IV bevestigden de door Luteijn in dit opzicht gepresenteerde bevindingen. Een in Maastricht uitge- 
voerde factoranalyse leidde tot de conclusie dat er wat de RG-schaal betreft, sprake is van éen onderliggende factor met een efgenwaarde van 4.07. A1s coëfficient voor interne consistentie werd Cronbach's alpha berekend. Deze bedroeg 0.80 .

ad.b. De door Schreurs, Tellegen, van de Willige (1984) ontwikkelde Utrechtse Coping Lijst (UCL) operationaliseert het concept copingstijlen in de vorm van een schriftelijke vragenlijst. Schreurs c.s. kwamen op basis van door hen uitgevoerde factoranalyses tot de conclusie dat de UCL uit 7 subschalen is opgebouwd. Tabel 6.6 . geeft een overzicht van deze subschalen en de door schreurs c.s. gevonden coëfficienten voor interne consistentie (Cronbach's alpha).

Factor-analyse over de UCL data van de in bijlage IV beschreven steekproef uit de Mastrichtse bevolking leverde vijf factoren en daarmee 5 subschalen op. Deze subschalen blijken overeen te komen met de door Schreurs onderscheiden $U \mathrm{UL}_{1}, U \mathrm{UL}_{2}, U \mathrm{UL}_{3}, U \mathrm{ULL}_{4}$ en $U C L_{7}$. Voor een eigen factor-structur van diens $U C L_{5}$ en $U C L_{6}$ werd geen bevestiging gevonden. Vandaar dat deze 2 subschalen dan ook niet in het verdere onderzoek werden betrokken. Tabe1 6.6. geeft tevens een overzicht van de in Maastricht gevonden factoren en coëfficienten voor interne consistentie.

Tabel 6.6. Overzlcht van in de UCh aangetoonde factoren en Interne conslstenties

\begin{tabular}{|c|c|c|c|}
\hline $\begin{array}{l}\text { factor } \\
\text { label } \\
\text { Schreurs }\end{array}$ & $\begin{array}{l}\text { Interne } \\
\text { consistentie } \\
\text { Schreurs. }\end{array}$ & $\begin{array}{l}\text { factor } \\
\text { labell } \\
\text { Maastr licht }\end{array}$ & $\begin{array}{l}\text { Interne } \\
\text { consistentie } \\
\text { Masstr licht }\end{array}$ \\
\hline $\begin{array}{l}\text { UCL, actief hert probleom } \\
\text { aanpakken }\end{array}$ & 0.82 & $\begin{array}{l}\text { ampakken als reactio } \\
\text { op spannlng }\end{array}$ & 0.77 \\
\hline $\mathrm{UCL}_{2}$ pall latloven & 0.74 & aflelding zooken & 0.73 \\
\hline $\mathrm{UCL}_{3}$ a fwachton on wermijdien & 0.73 & afwachten on vermlJ den & 0.71 \\
\hline$U_{C L}$ soclale steun zooken & 0.74 & steun zooken blj anderie & 0.182 \\
\hline $\mathrm{UCL}_{5}$ depresslef reactlo- & 0.69 & $-\infty$ & -- \\
\hline $\mathrm{LL}_{6}$ uiten van enotles & 0.62 & - & - \\
\hline $\begin{array}{l}\text { UCL, gerustellende cogin i- } \\
\text { tles }\end{array}$ & 0.67 & $\begin{array}{l}\text { Jezel f geruststellen, } \\
\text { relativeren }\end{array}$ & 0.71 \\
\hline
\end{tabular}


Het feit dat in Maastricht 5 factoren werden gevonden en in Utrecht 7, hangt samen met verschillen in de samenstelling van de steekproeven warop deze gegevens werden gebaseerd. Schreurs (1984) voerde $z$ ijn onderzoek uit bij 600 employees van de Nederlandse Spoorwegen. De leeftijd van de deelnemers aan dit onderzoek varleerde van 23 tot 64 jaar. De gemiddelde leeftijd was 43 Jaar. 4.4\% van de respondenten was van het vrouwelijk geslacht, $95,6 \%$ van het mannel ijke ges 7 acht.

Voor de Maastrichtse proefgroep geldt dat het aantal mannen en vrouwen ongeveer gelijk verdeeld was, ook was de leeftijdsverdeling beter verspreid over de drie onderscheiden leeftijdscategorieën (zie bijllage IV).

In het in dit proefschrift beschreven onderzoek wordt gebruik gemaakt van de UCL-subschalen 1 en 3 omdat deze schalen betrekking hebben op het aan- en afwezig zijn van instrumentele copingfuncties. De overige subschalen $\left(\mathrm{UCL}_{2}, U \mathrm{UL}_{4}, U C L_{7}\right)$ zijn minder relevant enwel vanwege het feit dat zij betrekking hebben op het aan-en afwezig zijn van palliatieve copingfuncties. In de persoonlijke vaardigheidstherapleën a la Goldstein ligt de nadruk op het aanleren van instrumentele copingstijlen en wordt geen aandacht besteed aan de uitbreiding van het palliatieve coping-repertoire wan de deelnemers.

ad.c. De door Appels $(1974,1975)$ ontwikkelde Delftse Vragenlijst operationaliseert het concept neuroticisme. Deze $11 j$ st heeft als voordeel boven andere neuroticisme-schalen dat ze kort, handzaam, snel af te nemen en te verwerken is.

Bleef het gebrulk van deze DV door Appells beperkt tot een studentenpopulatie, Arrimdel 1, Damsma en Ettema (1980) toonden aan dat de Delftse Vragenlijst ook bij anderssoortige populaties normalen en fobict - betrouwbar en valide is.

Factor-analyse over de in bijlage IV beschreven 377 cases bevestigde de veronderstelling dat de Delftse Vragenlijst uit éēn factor is opgebouwd met een eigenwaarde van 8.78 . De coëfficient voor interne consistentie bedroeg 0.92 . 
ad.d. In het hier beschreven onderzoek is ter operationalifatie van het IE-concept op pragmatische gronden gekozen voor de verkorte wersie van de oorspronkelijke $11 j$ st ontwikkeld door Emmelkamp (1975). Voor meer informatie over de psychometrische eigenschappen van deze 11jst, zie Emmelkamp (1975). De oorspronkelijke lijst werd ontwikkeld door Andriessen (1972).

Bij een factoranalyse over de in bijlage IV beschreven 377 cases bleek er sprake van ëén factor met een elgenwaarde van 3.17. De coëfficient voor interne consistentie bedroeg 0.77 .

ad.e. Als operationalisatie-wijze voor zelf-waardering werd de "selfesteem" (SE-)schaa) van Rosenberg (1965) gekozen. Deze schaa1 werd eerder toegepast in het door Beekers (1982) gerapporteerde effectonderzoek betreffende de interpersoonlijke vaardigheidstherapieën.

De Rosenberg-schaal werd voor het Nederlandse taalgebied vertaald en bewerkt door Sanders (1977) die ook de psychometrische eigenschappen ervan bepaalde. De door de Goldsteinprojectgroep toegepaste versie omvat 15 items met elk zes antwoordcategorieën. Factor-analyse over de in bijlage IV beschreven 377 cases leverde ëén factor op met een eigenwaarde van 5.34. De coëfficient voor interne consistentile bedroeg 0.88 .

Bij de bepaling van de divergerende validiteit geldt dat hoge correlaties tussen de DH-subschalen en de onder a $t / m$ e beschreven wragenlijsten impliceren dat deze 1 ijsten verwante constructen operationaliseren en dat hetgeen gemeten wordt door middel van de DH-subschalen, geen apart construct vormt met een eigen identiteitt zoals oorspronke$11 \mathrm{jk}$ beoogd werd. Hoge correlaties impliceren correlaties $\geq 0.70$.

Bljjkt er echter sprake te zijn van lage correlaties, dan betekent dat, dat de DH-subschalen bestaansrecht hebben als vragenlijsten die eigenstandige psychologische constructen operationaliseren.

In dit opzicht lage correlaties impliceert correlaties $\leq 0.70$.

In tabe1 6.7. wordt een overzicht gegeven van de correlaties tussen de scores op elk van de drie subschalen van de $\mathrm{DH}-1 \mathrm{j} j \mathrm{st}$ en de scores op de RG-schaal, de subschalen 1 en 3 van de UCL, de DV-schaal, de IEschaal en de SE-schaal. Deze correlaties werden berekend over de in bijlage IV beschreven proefgroep van 377 proefpersonen. 
Tobel 5.7. Overzlcht Pearson correllatles tussen $\mathrm{DH}_{11}, \mathrm{DH}_{2}, \mathrm{DH}_{3}$ on $\mathrm{RG}$, $\mathrm{UC}_{1}, \mathrm{UCL}_{3}, \mathrm{OV}$, IE IE SE.

\begin{tabular}{llll} 
& \multicolumn{1}{c}{$\mathrm{OH}_{1}$} & $\mathrm{DH}_{2}$ & $\mathrm{OH}_{3}$ \\
\hline $\mathrm{ROC}_{1}$ & $-0.22^{*}$ & -0.03 & 0.11 \\
$\mathrm{VCL}_{3}$ & $+0.41^{*}$ & $+0.42^{*}$ & $+0.37^{*}$ \\
$\mathrm{OH}^{*}$ & $-0.52^{*}$ & $-0.13^{*}$ & $-0.37^{*}$ \\
$\mathrm{IE}$ & $-0.63^{*}$ & $-0.12^{*}$ & $-0.40^{*}$ \\
$\mathrm{SE}$ & $+0.46^{*}$ & $+0.23^{*}$ & $+0.28^{*}$ \\
\hline
\end{tabular}

- slgnifficant p 0.001

Uit tabe1 6.7. kan men ten aanzien van DH-subschal 1 concluderen dat:

- deze subschaal significant negatief correleert met rigiditeit zoals gemeten met behulp van de rigiditeitsschaal uit de NPV.

- deze subschaal significant positief correleert met "actief het probleem aanpakken" als copingstijl $\left(\mathrm{UCL}_{3}\right)$ en significant negatief correleert met "afwachten/vermijden" als copingstijl $\left(\mathrm{UCL}_{3}\right)$.

- deze subschaal significant negatief correleert met neuroticisme zoals gemeten met behulp van de Delftse Vragenlijst.

- deze subschaal significant positief correleert met een interne "1ocus of control".

- deze subschal significant positief correleert met zelfwardering zoals gemeten met behulp van de SE-schaal.

Ten aanzien van DH-subschaal 1 kan men dus stellen dat deze subschaal öök aspecten van (instrumentele) copingstijlen, rigiditeit, neuroticisme, beheersingsoriëntatie en zelfwaardering meet. De correlaties zijn echter niet zo hoog dat er niet meer gesproken kan worden van operationalisatie van een eigenstandig construct. De correlaties zijn allen $\leq 0.70$. "Vertrouwen in eigen probleemoplossingsvaardigheid" zoals geoperationaliseerd in DH-subschaal $\mathbb{1}$ blijkt "meer" te zijn dan alleen een optelsom van aspecten van (instrumentele) copingstijlen, rigiditeit, neuroticisme, beheersingsoriëntatie en zelfwaardering. Wat dit "meer" inhoudt $k$ an op dit moment niet nader geconcretiseerd worden. 
Ten aanzien van DH-subschal 2 kan men concluderen dat:

- deze subschal niet significant correleert met rigiditeit zoals gemeten met behulp van de rigiditeitsschaal uit de NPV.

- deze subschaal significant positief correleer met actief het probleem aanpakken" als copingstijl (UCL 1 ) en significant negatief correleert met "afwachten/vernijden" als copingstijl (UCL $L_{3}$ ).

- deze subschaal significant negatief correleert met neuroticisme zoals gemeten met behulp van de Delftse Vragenlijst.

- deze subschaal significant positief correleert met interne "locus of control".

- deze subschal niet significant correleert met zelfwardering zoals gemeten met behulp van de SE-schal.

Ten aanzien van DH-subschaal 2 kan men dus stellen dat deze subschaal ook aspecten van (instrumentele) copingstijlen, neuroticisme en beheersingsoriëntatie meet. De correlaties zijun echter niet zo hoog dat er niet meer gesproken kan worden van operationalisatie van een eigenstandig construct. De correlaties zijn allen $\leq 0.70$. De hoogte van de gevonden correlaties is over het algemeen genomen lager dan bij subschaal 1 .

"Plannen en vooruitdenken" zoals geoperationaliseerd in DH-subschaal 2 blijkt "meer" te zijn dan alleen een optelsom van aspecten van linstrumentele) copingstijlen, neuroticisme en beheersingsorientatie. Wat dit "meer" inhoudt, kan op dit moment niet nader geconcretiseerd worden.

Tem aanzien van DH-subschaal 3 kan men conciuderen dat:

- deze subschal niet significant correleert met rigiditelit zoals. gemeten met behulp wan de rigiditeitsschaal uit de NPV.

- deze subschaal significant positief correleert met "actief het probleem aanpakken" als copingstijt (UCL ${ }_{1}$ ) en significant negatief correleert met "afwachten/vermijden" als copingstifl (UCL 3 ).

- deze subschal significant negatief correleert met neuroticisme zoals gemeten met behulp van de Delftse Vragenlijst.

- deze subschal significant positief correleert met een interne "locus of control". 
- deze subschaal significant positief correleert met zelfwardering zoals gemeten met behulp van de SE-schaal.

Ten aanzien van DH-subschaal 3 kan men dus stellen dat deze subschaal ook aspecten van (instrumentele) copingstijlen, neuroticisme, beheersingsorientatie en zelfwaardering meet. De correlaties zijn echter niet zo hoog dat er niet meer gesproken kan worden van operationalisatie van een eigenstandig construct. De correlaties zijn allen $\leq 0.70$. De hoogte van de gevomden correlaties is over het algemeen genomen 1 ager dan bij subschaal 1 .

"Consequent handelen" zoals geoperationaliseerd in DH-subschal 3 blijkt "meer" te zijn dan aleen een optelsom van aspecten van linstrumentele) copingstijlen, neuroticisme, beheersingsoriëntatie en zelfwaardering. Wat dit "meer" inhoudt, kan op dit moment niet nader geconcreti seerd worden.

6.4.6. Invloed van demografische variabelen op de vragenlijstscores

Besloten werd na te gaan in hoeverre de variabelen leeftijd, geslacht en opleidingsniveau van invloed waren op de scores op de 3 subschalen van de $\mathrm{DH}-1$ ijst.

In tabel 6.8. wordt een overzicht gegeven van de correlaties tussen de totaalscores op elk van de subschalen afzonderlijk en de variabele leeftijd.

Tabel 6.8. Parson correlatles tussen totallscore per vraganll jst en $100+1] d$

\begin{tabular}{|c|c|c|c|}
\hline & & $20 t+110$ & \\
\hline tatual scoro & $\begin{array}{l}\mathrm{DH}_{4} \\
\mathrm{OH}_{3} \\
\mathrm{OH}_{3}\end{array}$ & $\begin{array}{r}-0.05 \\
0.09 \\
0.03\end{array}$ & $\begin{array}{l}\text { nlet slgnlf lcant } \\
\text { nlet slgniflicent } \\
\text { nlet slgnifl cant }\end{array}$ \\
\hline
\end{tabular}

Bovenstaande tabel toont aan dat er geen significante invloed aantoonbaar is van de variabele leeftijd op de totaalscore per subschaal. 
Teneinde de invioed van de variabele geslacht te bepalen, werd per" subschaal een twee-zijdige t-toets uitgevoerd. Door middel van deze t-toetsen werden in dit opzicht aamwezige verschillen op slignificantie getoetst.

Tabel 6.9. geeft een overzicht van gevonden t-warden en significantie-niveau's.

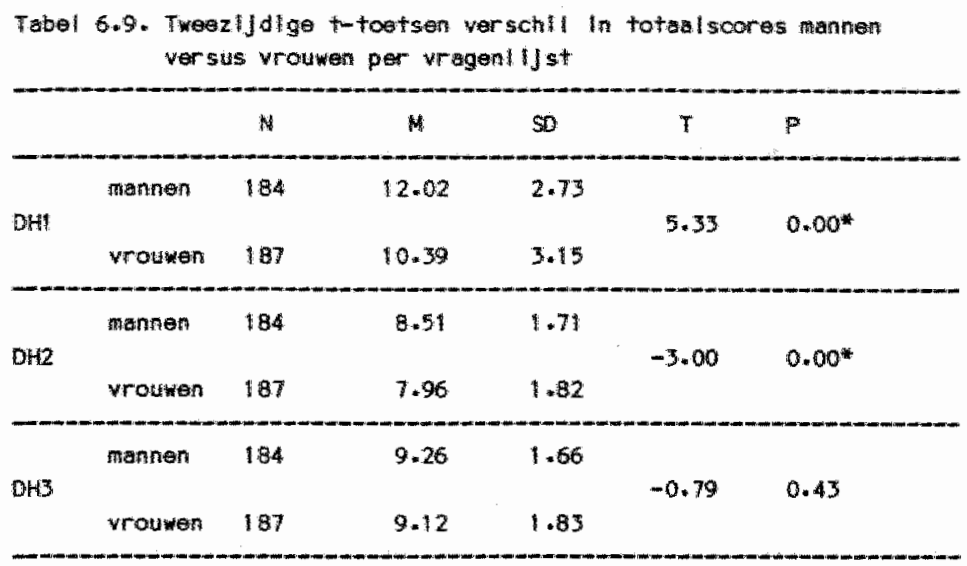

* signiflicant op p $\leqslant 0.05$ niveat

Uit tabel 6.9. blijkt dat de varfabele geslacht significant van invloed is op de totaalscores op $\mathrm{DH}_{1}$ en $\mathrm{OH}_{2}$. Wat betreft $\mathrm{DH}_{3}$, z geen significante verschillen tussen mannen en vrouwen aantoonbaar. Bovenstaande impliceert dat vrouwen, in vergelfjking tot mannen over het algemeen genomen:

- minder vertrouwen hebben in hun eigen probleemoplossingsvaardigheld - zichzelf minder als vooruitdenkers/planners beschrijuen.

Tenslotte werd het verband bepald tussen de variabele opleidingsniveau en de totaalscore per subschaal van de DH-11jst. Tabel 6.10. geeft een overzicht van de resultaten van de daartoe uftgevoerde variantie-analyses. 

subschal versus opletillingsmiveau

\begin{tabular}{cll} 
Totailscore & $F$ & signiflicantile \\
& $\alpha=0.05$ & \\
\hline $\mathrm{DH}_{1}$ & 4.38 & $.00^{*}$ \\
$\mathrm{OH}_{2}$ & 4.60 & $.00^{*}$ \\
$\mathrm{OH}_{3}$ & 2.50 & $.01^{*}$ \\
\hline
\end{tabular}

* signifllcant op $\$ 0.05$ niveau

Uit bovenstaande tabel kan men afleiden dat de variabele opleidingsniveau significant van invloed is op de totalscore per subschaal en wel in die zin dat een hoger opleidingsniveau gepaard gaat met een signficant hogere score op elk van de drie subschalen.

Wat de demografische variabelen betreft kan men dus concluderen dat de variabele leeftijd geen significante invloed heeft op de totalscores per subschaal, de variabel en geslacht en opleidingsniveau wèl.

\subsection{SAMENVATTING EN CONCLIISIES TEN AANZIEN VAN DE DH-LIJST}

In dit hoofdstuk werden de constructie en validering beschreven van een meetinstrument ter evaluatie van de effecten wan persoonlijke vaardigheidstherapleën. Bij factoranalytisch onderzoek bleek de geconstrueerde vragenl ijst "Doelmatig Handelen" opgebouwd uit 3 subschalen. Analyse van de inhoud van de betreffende items leidde ertae de gevonden subschalen als volgt te benoemen:

a. "vertrouwen in eifgen probleemoplossingsvaardigheid" $\left(\mathrm{DH}_{1}\right)$

b. "plannen en vooruitdenken" $\left(\mathrm{DH}_{2}\right)$

c. "consequent handelen" $\left(\mathrm{DH}_{3}\right)$.

Voor elk van deze subschalen werd de coëfficient voor interne consistentie (Cronbach"s alpha) bepaald en de test-hertest betrouwbaarheid vastgesteld. De in dit opzicht gevonden waarden varieerden van 0.61 0.82 . DH-subschaal 1 vormt de in dit opzicht sterkste schaal; DH-subschaal 3 de zwakste. Ook werd nagegaan in hoeverre de variabelen leeftijd, geslacht en opleidingsniveau van invloed waren op de scores op de 3 DH-subschalen. De variabele leeftijd bleek geen significante in- 
vloed te hebben op de totalscores per subschaal, de variabelen geslacht en opleidingsniveau wel.

Bij de bepaling van de divergerende validiteit van de 3 subsubschalen bleek dat de $\mathrm{DH}_{2}$ ook aspecten van (instrumentele) copingstijlen, neuroticisme en beheersingsorientatie meet. $\mathrm{DH}_{3}$ blijkt bovendien aspecten van zelfwaardering te meten en $\mathrm{DH}_{1}$ aspecten van zelfwaardering en aspecten van rigiditeit. De hoogte wan de gevonden correlaties is echter niet zodanig dat er geen sprake meer is van operationalisatie van eigenstandige aspecten van persoonlijke (on)vaardigheid. Deze aspecten kunnen op dit ogenblik niet nader geconcretiseerd worden. Er werd niet gecontroleerd op sociale wenselijkheid.

De hierboven beschreven resultaten van het onderzoek naar de psychometrische elgenschappen van de 3 subschalen van de DH-lijst kunnen bevredigend worden genoend. Op basis van bovenstaande gegevens, werd dan ook besloten DH-subschal 1,2 en 3 als effectiviteitscriteria in aanmerking te nemen $b i j$ het in hoofdstuk 7 te beschrijven onderzoek naar de effecten van de in dit proefschrift beschreven persoonlijke vaardigheidstherapieën. 


\subsection{INLEIDING}

Hoofdstuk 7 vormt het verslag van een onderzoek naar de effecten van de in dit proefschrift beschreven persoonlijke vaardigheidstherapieën. Achtereenvalgens zall aandacht worden besteed aan de opzet van dit onderzoek (7.2.), de keuze van criteria en meetinstrumenten (7.3.) en de beschrijuing van proefgroep 17.4.). In 7.5. wordt de wijze wan dataverzameling aan de orde geste1d. 7.6. en 7.7. behandelen dataverwerking en resultaten. De resultaten worden per criterium weergegeven. Dok wordt nagegaan of er sprake is van stabiliteit van bereikte resultaten na een jaar. In 7.8. wordt aandacht besteed aan samenvatting en conclusies.

\subsection{OPZET VAN EFFECTIVITEITSONDERZOEK}

Bij de bepaling van de effecten van persoonlijke vaardigheidstherapieën gaat het om de vraag of en 20 ja in welke mate de ontwikkelde therapie programma's aan hun doel beantwoorden.

Het onderzoek werd opgezet conform het door Beekers (1982) verricht onderzoek naar de effecten van interpersoonlijke vaardigheidstherapieën. Ten aanzien van de persoonlijkke vaardigheidstherapieën geldt dat de constructie van meetinstrumenten specifieke probiemen oplevert gezlen het feit dat tijdens deze vaardigheidstherapieën de nadruk ligt op het aanleren van covert c.q. "denk"gedrag. In tegenstelling tot overt gedrag wordt covert gedrag gekenmerkt door het felt dat dit niet direct warneembaar is en veelal alleen indirect kan worden waargenomen. Dit heeft directe gevolgen voor de meetbaarheid ervan. In het nu volgende zal worden nagegaan of de ontwikkelde vaardigheidstheraple-programma's in staat blijken de daarmee beoogde doelstellingen te realiseren. $E r$ is geen sprake van evaluatie met behulp van directe vaardigheidstoetsen en/of andere vormen van gedragsobservatie(s). Evaluatie van berelkte resultaten vindt plaats aan de hand van 
bestaande en zelf-geconstrueerde vragenlijsten die in dit opzicht relewante pychologische concepten operationaliseren. In het onderhavlge onderzoek zijn zowel een controle-condite als een follow-up meting verdisconteerd. Het gehanteerde evaluatie-instrumentarium werd op psychometrische eigenschappen onderzocht vooraf aan de ultwoering van het effectiviteitsonderzoek. Bovendien werden door mide van training en instructies van de therapeuten de nodige voorzieningen getroffen. ter untomering van de uitvoering van de persoonlijke vaardigheldstherapleën lvoor een beschrijuing van gehanteerde theraple-protocollen zie hoofdstuk 3 alsook bijlage I en III.

\subsection{EFFECTIVITEITSCRITERIA EN MEETINSTRUMENTEN}

In hoofdstuk 5 werd reeds duidelijk gemakt dat de aldaar beschreven cognitlef sociaal-leertheoretische verklaringsmodellen ook impllcaties hebben voor effectiviteitsonderzoek. De theorie van Rotter geeft er asnlelding toe de "locus of control" in het effectiviteltsonderzoek te betrekken. De theorie van Bandura benadrukt het belang van persoonlijke competentie-wardering en de theorie van Lazarus dat van appraísal processen en copingstijlen.

Rigiditeit werd als relevante dimensie in ammerking genomen omdat men mag verwachten dat rigiditeit persoonlijke vardigheid negatief zal beinvioeden.

Naast bovengenoemde meer algemene psychologische criterla werd ook het in hoofdstuk 6 beschreven meetinstrument ter operationalisatie van persoonlijke (on)vaardigheid als effectiviteitscriterium in aanmerking genomen. Dit meetinstrument, ook wel vragenlijst Doellmatlg Handelen genoemd, bestaat uit 3 subschalen, te weten:

- vertrouwen in eigen probleemoplossingsvaardigheid (DH ${ }_{1}$ )

- plannen en woorultdenken $\left(\mathrm{DH}_{2}\right)$

- consequent handelen $\left(\mathrm{DH}_{3}\right)$

Voor een overzicht van de psychometrische elgenschappen van deze vragenlijst zie hoofostuk 6 .

Voor een overzicht van de wijze waarop locus of control, zelfwaardering, copingstijlen en rigiditeit werden geoperationaliseerd, zle 
6.4.5. In de betreffende paragraaf treft men tevens een overzicht aan van de psychometrische eigenschappen van de vragenlijsten die werden gekozen als operationalisering van deze algemene psychologische constructen.

In het nu volgende zal elk van de gehanteerde effectiviteitscriteria afzonderlijk worden beschreven wat betreft de in relatie daartoe geformuleerde vraagstelling.

7.3.1. Uitbreiding van het "vertrouwen in eigen probleemoplossingsvaardigheid" $\left(\mathrm{DH}_{1}\right)$

De dimensie "Vertrouwen in elgen probleemoplossingsvaardigheid" werd geoperationaliseerd met behulp van de in hoofdstuk 6 beschreven DHsubschaal 1. Verwacht wordt dat deelname aan persoonlijke vaardigheidstherapieën zal leliden tot een grotere mate van vertrouwen in eigen probleemoplossingsvaardigheid bij de deelnemers.

7.3.2. Verandering ten aanzien van "plannen en vooruitdenken" $\left(\mathrm{DH}_{2}\right)$

DH-subschaal 2 operationaliseert de mate waarin een individu zichzelf als een planner en vooruitdenker beoordeelt. Verwacht wordt dat deelname aan persoonlijke vaardigheidstherapleën leidt tot een versterking van de neiging tot plannen en voorult tdenken.

7.3.3. Verandering ten aanzien van "consequent handelen" $\left(\mathrm{DH}_{3}\right)$

DH-subschal 3 operationaliseert de mate warin een individu consequent handelt. Verwacht wordt dat deelname aan persoonlijke vaardigheidstherapieën leidt tot een versterking van de neiging tot "consequent handelen". 
Locus of control werd geoperationaliseerd met behulp van de door Emmelkamp (1975) ontwikkelde variant op de IE-schaal van Andriessen (1972). Verwacht wordt dat deelname aan persoonlijke vaardigheidstherapieën de IE-oriëntatie van de deelnemers zal veranderen in de richting van meer interne controle.

\subsubsection{Vergroting van zelfwaardering}

Zelfwaardering werd geoperationaliseerd met behulp van de Self-Esteem (SE) schaal, ontwikkeld door Rosenberg (1965) en vertaald en bewerkt door Sanders (1977).

Tijdens de persoonlijke vaardigheidstherapieën wordt ernaar gestreefd specifieke persoonlijke vaardigheden c.q. competentie(s) uit te breiden en te versterken. Hetzelfde geldt ten aanzien van de verwachtingen van het betreffende individu met betrekking tot deze competenties en/of vaardigheden. Verwacht wordt dat uitbreiding en versterking van specifieke persoonlijke vaardigheden c.q. competentie(s) een toename in de mate van a-specifieke zelfwaardering tot gevolg heeft. De term a-specifieke zelfwaardering verwijst naar een gegeneraliseerd vertrouwen in eigen competentie(s) en/of vaardigheden. Een en ander leidt tot de veronderstelling dat deelname aan persoonlijke vaardigheidstherapieën een toename in algemene zelfwaardering tot gevolg zal hebben.

\subsubsection{Vermindering van rigiditeit}

Het gedragskenmerk rigiditeit werd geoperationaliseerd met behulp van de RG-schaal uit de NPV (Lutefjn, 1974). Verwacht wordt dat deelname aan persoonlijke vaardigheidstherapieën tot gevolg zal hebben dat de rigiditeit van de deelnemers zal verminderen omdat men meer gedragsal ternatieven ter beschikking krijgt. 
Het concept copingstijlen werd geoperationaliseerd met behulp van de door Schreurs e.a. (1983, 1984) ontwikkelde Utrechtse Coping-Lijst (UCL). In deze lijst zijn zeven verschillende copingstijlen opgenomen. In hoofdstuk 6 werd reeds aangegeven welk van deze copingstijlen in dit kader relevant zijn.

Verondersteld wordt dat deelname aan persoonlijke vaardigheidstherapieën zal leiden tot een hogere score op UCL 1 ("aanpakken als reactie op problemen") en een lagere score op $\mathrm{UCL}_{3}$ ("afwachten, vermijden").

\subsection{PROEFPERSONEN}

In een periode van 2 jaar werden pre-, post- en follow-up metingen verricht bij 52 deelnemers aan persoonl ijke vaardigheidstherapieën.

\subsubsection{Experimentele groep}

De experimentele groep wordt gevormd door een groep clienten/patienten van een viertal instellingen voor ambulante danwel $k 1$ inische geestelijke gezondheidszorg.

Voor al deze clienten/patienten geldt dat zij aan persoonlijke vaardigheidstherapieën deelnamen omdat hun individuele behandelaars van oordeel waren dat $2 i j$ aan de in 3.3. beschreven indicatie-criteria voldeden. Op deze clienten werd geen enkele vorm van verdere selectie toegepast door de persoonlijke vaardighefdstherapeuten.

Ten tijde van deelname aan de persoonlijke vaardigheidstherapieën werden de contacten met de individuele behandelaars in de regel opgeschort of geminimail seerd.

Bij al deze clienten/patienten zijn ook enige biografische gegevens verzameld. Van de totale groep is $59 \%$ van het mannelijk geslacht, $41 \%$ van het vrouwelijk geslacht. $10 \%$ is jonger dan 25 jaar, $6 \%$ ouder dan 55 jaar. $29 \%$ is $\geq 25$ jaar en < 35 jaar. Nog eens $29 \%$ is $\geq 35$ jaar en< 45 jaar. $25 \%$ is $\geq 45$ jaar en $\leq 55$ jaar. Terwij $157 \%$ gehuwd is of sa- 
menwoont, blijkt $20 \%$ ongehuwd, $22 \%$ gescheiden en $2 \%$ weduwe of weduwnaar. 29\% heeft geen baan buitenshuis.

Wat schoolloopbaan betreft, b1ijkt 61\% lager onderwijs te hebben gevolgd plus éen of twee jaar vervolgonderwijs, $16 \%$ voltooide een lagere beroepsopleiding, 14\% voltooide MULO/MAVO-onderwijs, $10 \%$ genoot meer onderwijs. Allen blijken via het Ziekenfonds verzekerd.

De experimentele groep nam deel aan persoonlijke vaardigheidstherapieën ontwikkeld voor Libo-clienten/-patienten. Deze therapieën werden op vier verschillende plekken in de geestelijke gezondheidszorg toegepast. Variërend naar reden van verwijzing c.q. aard van de aanwezige problematiek, kan men vier subgroepen clienten onderscheiden, te weten:

1. LIBO-clienten met overwegend psychosociale problematiek in behandeling bif de RIAGG-Heerlen (=AGGZ-groep):

2. LIBO-clienten met (sociaa1-)psychiatrische problematiek, in behandeling bij het team Langdurige Structurende Begeleiding van de RIAGG-Maastricht (=SPD-groep).

3. LIBO-clienten met overwegend psychiatrisch bepaalde WAO-problematiek, in behandeling bij het preventieteam van de RIAGG-Sittard (=WAO-groep).

4. LIBO-clienten opgenomen op de Afdeling Klinische Gedragstherapie van het Psycho-Medisch Streekcentrum Vijverdal vanwege ernstige fobische, dwang- en/of depressieve symptomatologie (=AKG-groep).

Groep 1 vertegenwoordigt clienten die tot de mildere probleem-categorieën kunnen worden gerekend. Groep 2, 3 en 4 vertegenwoordigen clienten die tot de meer ernstige probleem-categorieën kunnen worden gerekend.

Groep 1 - de AGGZ-groep - nam deel aan de persoonlijke vaardighefdstherapieën "dagelijkse problemen aanpakken" en "veranderingen aanpakken".

Groep 2 - de SPD-groep - nam deel aan de persoonlijke vaardigheidstherapieèn "dagelijkse problemen aanpakken", "beslissîngen nemen" en "veranderingen aanpakken".

Groep 3 - de WAD-groep - nam deel aan de persoonlijke vaardigheids- 
therapieën "dagelijkse problemen aanpakken", informatte verzamelen" en "veranderingen ampakken".

Groep 4 - de AKG-groep - nam dee1 aan de persoonlijke vaardigheidstherapleën "dagelijkse problemen aanpakken", "beslissingen nemen", "informatle verzamelen" en "veranderingen aanpakken".

onderlinge vergelljking wan de experimentele groep total en de in 6.4.1. beschreven steekproef uit de Mastrichtse bevolking leilde tot. de in tabe1 7.1. weergegeven resultaten.

Tabel 7.1 . Overzlcht resultaten comarlantlo-anilyse steekproef Maastrlchtenaren wersus cl lenten met ls covarlaton gesllacht, leftldo on opleldingsil weaw

\begin{tabular}{|c|c|c|c|c|}
\hline & Soort groep & N & M-aangepast & slgnl flcant versch 1 \\
\hline \multirow{3}{*}{$\mathrm{OH}_{1}$} & cllentan & 38 & 5.23 & \multirow{3}{*}{ Ja*** } \\
\hline & & & & \\
\hline & s teekproef & 326 & 11.05 & \\
\hline \multirow{3}{*}{$\mathrm{DH}_{2}$} & cllentiten & 38 & 8.12 & \multirow{3}{*}{$J a *$} \\
\hline & & & & \\
\hline & steokproef & 326 & 8.76 & \\
\hline \multirow{3}{*}{$\mathrm{DH}_{3}$} & cl lenten & 38 & 6.79 & \multirow{3}{*}{$\ln * * * *$} \\
\hline & & & & \\
\hline & steokproef & 326 & 8.64 & \\
\hline \multirow{3}{*}{$\mathrm{NCL}_{1}$} & cllenten & 38 & 16.32 & \multirow{3}{*}{ Ja **** } \\
\hline & & & & \\
\hline & steekproes $f$ & 326 & $20.2 B$ & \\
\hline \multirow{3}{*}{$\mathrm{UCE}_{3}$} & cllienten & 38 & 12.66 & \multirow{3}{*}{$J_{a} * *$} \\
\hline & & & & \\
\hline & steokproef & 326 & 13.96 & \\
\hline \multirow{3}{*}{ IE } & ellanten & 38 & 38.16 & \multirow{3}{*}{$J a * * *$} \\
\hline & & & & \\
\hline & steekp roef & 326 & 43.30 & \\
\hline \multirow{3}{*}{ SE } & cllenten & 38 & 40.81 & \multirow{3}{*}{$j a * * *$} \\
\hline & & & & \\
\hline & steekproef & 326 & 53.73 & \\
\hline & cllenten & 38 & 27.61 & \multirow{3}{*}{ nen } \\
\hline \multirow[t]{2}{*}{ RiG } & & & & \\
\hline & steokproef & 326 & 26.28 & \\
\hline
\end{tabular}

- p<.05

* $p<.01$

*.*.001 
Uit tabel 7.1. blijkt dat clienten in vergelijking tot de steekproef Mastrichtenaren:

- significant minder vertrouwen hebben in eigen probleemoplossingsvaardigheid $\left(\mathrm{DH}_{1}\right)$.

- significant minder plannen en vooruitdenken $\left(\mathrm{DH}_{2}\right)$.

- significant minder geneigd zijn consequent te handelen $\left(\mathrm{DH}_{3}\right)$.

- significant minder gebruik maken van copingstijl UCL $L_{\mathbb{1}}$ "aanpakken als reactie op problemen".

- significant meer gebruik maken van copingstijl $\mathrm{UCL}_{3}$ "afwachten, vermijden".

- significant meer exterm georienteerd zijn.

- significant minder zelfwaardering hebben.

Ten aanzien van rigiditeit blijken geen significante verschillen aantoonbaar tussen de steekproef Maastrichtenaren en de groep clienten.

Voor een overzicht van de biografische gegevens ten aanzien van de steekproef Maastrichtenaren zle bijlage IV.

\subsubsection{Controlegroep}

De controlegroep wordt gevormd door een groep clienten/patienten van dezelfde instellingen voor ambulante danwel klinische geestelijke gezondheidszorg als de experimentele groep. Voor de deelnemers aan de controle-conditie geldt dat zij allen langer dan 4 weken moesten wachten alvorens zij aan persoonlijke vaardigheidstherapieën konden deelnemen. Tfjdens deze wachtperiade liep het contact tussen de toekomstige deelnemer en ziljn hoofdbehandelaar/verwijzer normaal door. De aard van dit behandelingscontact werd niet nader onderzocht.

Bij clienten, waarvan te voorzllen was dat zij een periode op de wachtlijst zouden doorbrengen, werden aldus een aantal "controlemetingen" verricht on vast te stellen of de verkregen resultaten inderdaad in grotere mate bereikt worden door deelname aan een persaonlijke vaardigheidstherapie dan door "spontaan" herstel en/of anderssoortige behandeling. 
De controlegroep bestond wit 34 proefpersonen. Van deze mensen is $65 \%$ van het mannelijke en $35 \%$ van het vrouwelijke geslacht. $6 \%$ van deze personen is jonger dan 25 jaar, $9 \%$ ouder dan 55 jaar. 38\% is $>25$ jaar en < 35 jaar. $35 \%$ is $\geq 35$ jaar en $<45$ jaar. $12 \% \geq 45$ jaar en $\leq 55$ jaar. Terwijl $62 \%$ gehuwd is of samenwoont, blijkt $18 \%$ ongehuwd, $21 \%$ gescheiden. Er zijn geen weduwen en/of weduwnaars in deze groep aanwezig. 62\% van deze mensen heeft geen baan buitenshuis. Wat schoolloopbaan betreft, blijkt $47 \%$ lager onderwijs te hebben gevolgd plus éen of twee jaar vervolgonderwijs, 33\% vol tooide een lagere beroepsopleiding, $15 \%$ vol tooide MULO/MAVO-onderwijs, 6\% genoot meer onderwijs. Allen b1 ijken via het Zlekenfonds verzekerd.

\subsection{DATAVERZAMELING}

In het nu volgende worden achtereenvolgens de wijze van dataverzameling en de tijdstippen van dataverzameling beschreven.

\subsubsection{Wijze van dataverzameling}

In het kader van zowel de controle als de experimentele metingen werden de betrokken clienten uitgenodigd voor een semi-gestructureerd interview. Deze interviews werden gehouden door verschillende projectgroepleden, met name collega-psychologen en doctoraal-studenten Socia1e Gezondheidkunde van de Rijksuniversiteit Limburg. Als vaste regel werd daarbij gehanteerd dat de interviewer geen therapeut van de betreffende client mocht zijn. De intervilewer organiseerde, telefonisch of schriftelijk, een ontmoeting met de betreffende clifent. De SEschaal, RG-schaal, IE-1ijst, DH-lijst en de Utrechtse Coping Lijst werden zelfstandig ingevuld door de betreffende clienten, de Biografische Vragemiljst werd door de interviewer afgenomen.

Af en toe is er sprake van onvolledige meetpakketten tengevolge van het feit dat een aantal interviews om redenen van tijd en organisatie moesten wordlen afgebraken voordat alle scores waren verzameld. 
De voometing vond plats een week voordat de experimentele, damwel controleconditie inging. De nameting werd gehouden \pm eeèn week na beeindiging van experimentele danwel controle-fase. De follow-up meting vond plaats \pm 12 maanden na beëindiging van de betreffende vaardigheidstherapie. Deze herhaalde meting na een jaar kan niet worden opgevat als een follow-up meting in de strikte zin van een herhaalde meting na een intervalperiode zonder therapeutische interventie(s). Vrijwel alle deelnemers aan persoonl ijke vaardigheidstherapieën gaan immers na afloop terug naar hun verwijzer $c . q$. hoofdbehandelaar. Alleen voor de WAO-groep was dit niet het geval. Ook kon niet worden nagegaan wat er tijdens deze periode aan min of meer ingrijpende levensgebeurtenissen (=life events) heeft platsgevonden bij de betreffende individuen. Dergelijke gebeurtenissen kunnen de follow-up resultaten in positieve dan wel negatieve richting vertekenen.

\subsection{DATAVERHERKING EN RESULTATEN}

Onderzoek sbevindingen, verwerkingsmethoden en resul taten zullen worden beschreven per criterium c.q. per ter operationalisatie daarvan gehanteerd meetinstrument in 7.6.1. $t / m .7 .6 .7$. Met behulp van t-toetsen wordt nagegaan:

- of experimentele en controlegroep al dan niet significant van elkaar verschillen op de voormeting (2-zijdige toetsing),

- of de controlegroep bij de nameting significant anders scoort dan bij de voormeting (2-zijdige toetsing),

- of de experimentele groep bij de nameting significant hoger scoort dan bij de voormeting (eenzijdige toetsing).

De experimentele metingen hebben betrekking op cllenten die $\geq 75 \%$ van de groepsbijeenkomsten hebben meegemaakt. In 7.6.8. wordt aandacht besteed aan de stabiliteit van de effecten na een jaar.

De resultaten zullen over de totale groep al sook per subgroep - AGGZ, SPD, WAO, AKG - worden weergegeven. 
7.6.1. Effecten ten aanzien van "vertrouwen in eigen probleemoplossingsvaardigheid" $\left(\mathrm{DH}_{1}\right)$

Wat DH-subschaal 1 betreft, zijn 51 experimentele en 31 controle-metingen verzameld. Beide groepen verschillen niet significant van elkaar op de voormeting $(T=1.32 ; n .5$.$) .$

Tabe1 7.2. geeft een overzicht van de gevonden verschilien tussen voor- en nameting voor controle- en experimentele groep. Wat de experimentele groep betreft, worden de resultaten totaal en per subgroep weergegeven.

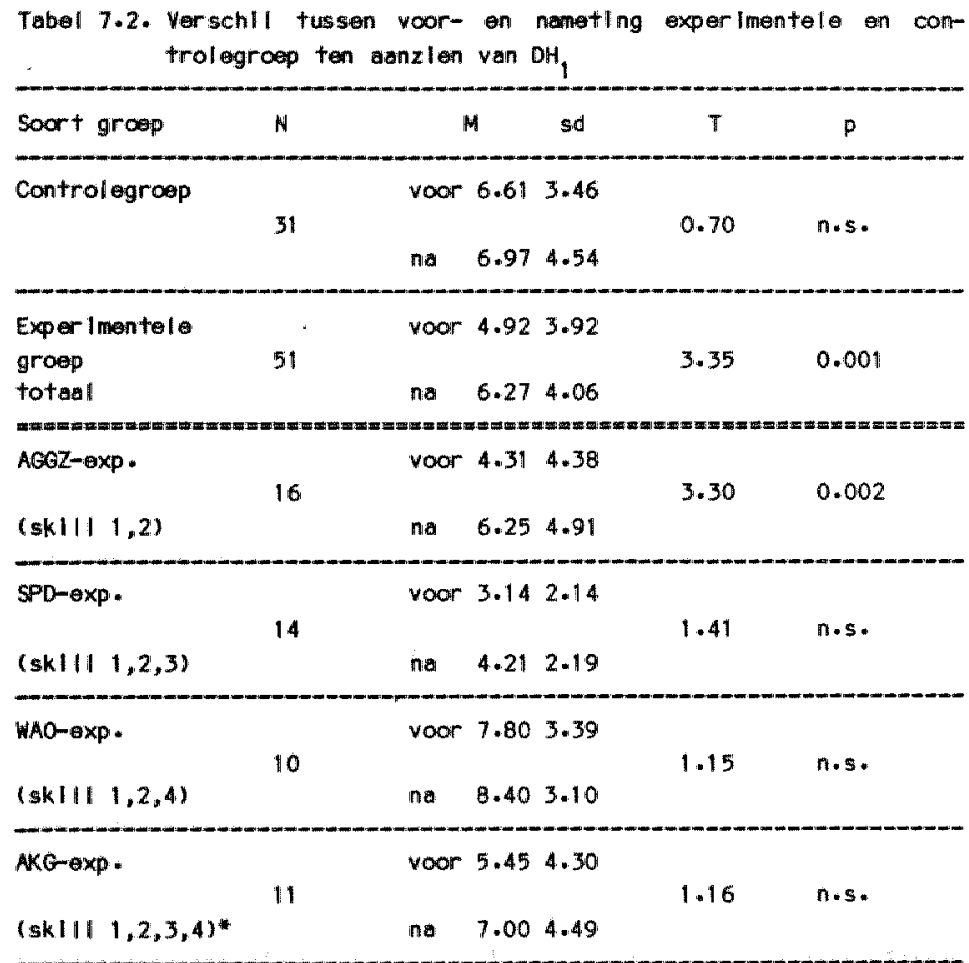

* skll| 1 - agiell Ijkse problemen aanpakkan

sk $\| 112$ = warander Ingen aanpakken:

skIII 3 - besillsilngen nemen

skll| 4 . Informatl verzamelen 
Tabel 7.2. laat zien dat er significante verschillen aantoonbaar zijn tussen voor- en nameting ten aanzien wan $\mathrm{DH}_{1}$ bij de experimentelle groep totaal en bij de AGGZ-subgroep. Noor beide groepen geldt dat deelname aan persoonlijke vaardigheidstherapieën het "vertrouwen in eigen probleemoplossingsvaardigheid" vergroot. Wat de controlegroep betreft, zijin geen significante verschillen tussen voor-en nameting aantoonbar.

7.6.2. Effecten ten aanzien van "plannen en voopuitdenken" $\left(\mathrm{OH}_{2}\right)$

Wat DH-subschaal 2 betreft, zijn 52 experimentele en 30 controle metingen verzameld. Beide groepen verschillen niet significant van elkaar op de voormeting $(T=-0.42 ; n . s$.$) .$

Tabel 7.3. geeft een overzicht van de gevonden verschillen tussen voor- en nameting wat betreft $\mathrm{DH}_{2}$ ten aanzien van experimentele en controlegroep. Wat de experimentele groep betreft, worden de resultaten total en per subgroep weergegeven.

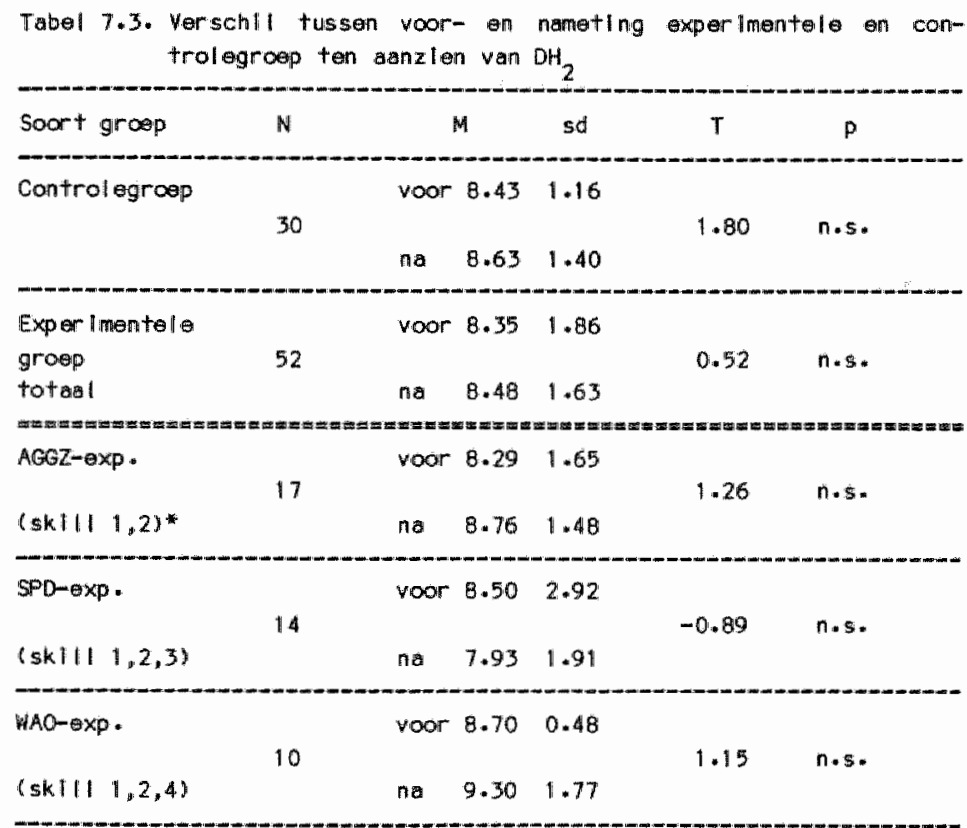




\begin{tabular}{|c|c|c|c|c|c|}
\hline \multirow[t]{2}{*}{ Hom } & & voor & 7.91 & 1.14 & \multirow{3}{*}{0.18} \\
\hline & 11 & & & & \\
\hline $4 s k \| 11$ & & $n$ & 8.00 & 1.67 & \\
\hline
\end{tabular}

- skil I I sage I Ikse probl men anpakken

skll| 2 wer ander Ingen a makken

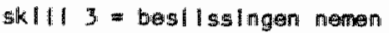

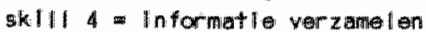

Tabel 7.3. 1 aat zien dat er geen significante verschillen aantoonbaar zijn ten aanzien van $\mathrm{DH}_{2}$. Dit geldt voor de experimentele groepen zowel als voor de controlegroep.

7.6.3. Effecten ten aanzien van "consequent handelen" $\left(\mathrm{DH}_{3}\right)$

Wat DH-subschaal 3 betreft, zijn 51 experimentele metingen en 30 controlemetingen verzameld. Beide groepen verschillen niet significant van elkaar op de voormetïng $(T=-1.79$; n.s.).

Tabel 7.4. geeft een overzicht van de gevonden verschillen tussen voor- en nameting wat betreft $\mathrm{DH}_{3}$ ten aanzien van experimentele en controlegroep. Wat de experimentele groep betreft, worden de resultaten total 1 en per subgroep weergegeven.

Tabel 7.4. Verschll tussen voor- en nameting exper Inentele en controlegroep tem aamzlen van $\mathrm{DH}_{3}$

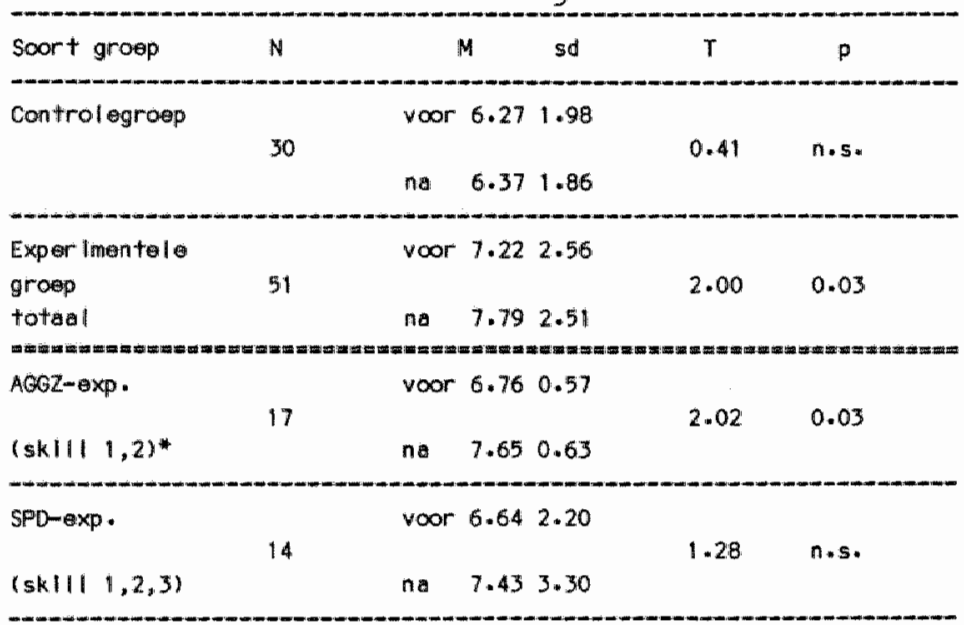




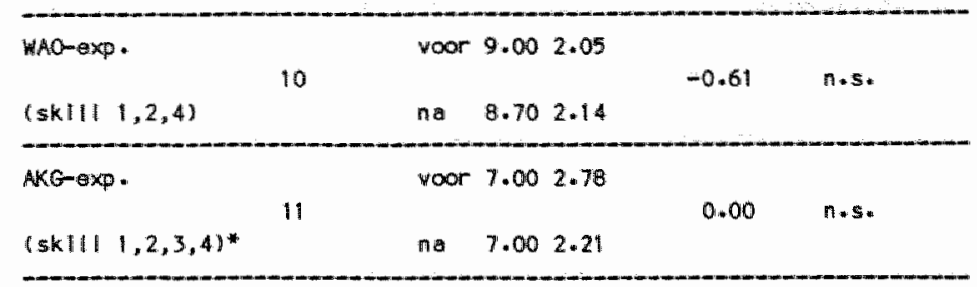

* sklll = dagelljkse problamen aanpakkon

skll 2 merander Ingen aenpakken

sklll 3 a beslissingen memen

skll 4 informatio verzanelen

Tabe1 7.4. laat zien dat er significante verschillen tussen voor- en nameting aantoonbaar zijn ten aanzien van $\mathrm{DH}_{3}$ bij de experimentele groep total en bij de controlegroep. Voor beilde groepen geldt dat deelname aan persoonlijke vaardigheidstherapieën de mate van "consequent handelen" significant doet toenemen. Wat de controlegroep betreft, zijn geen significante verschillen tussen voor- en mameting aantoonbaar.

7.6.4. Effecten ten aanzien van lacus of control

Wat lacus of control betreft, zijn 41 experimentele en 30 controlemetingen verzameld. Beide groepen verschillen niet significant van elkaar op de voormeting ( $T=1.57$; n.s.).

Tabel 7.5. geeft een overzicht van de gevonden verschillen tussen voor- en nameting wat betreft locus of control ten aanzien van experimentele en controlegroep. Wat de experimentele groep betreft, worden de resultaten totaal en per subgroep weergegeven. Bij de AKG-groep werden geen gegevens ten aanzien van locus of control verzameld. 
Tabie 7.5* Verchll tussem woor- an maneting exper lantele en controlagrapen ten anzlen van lows of control

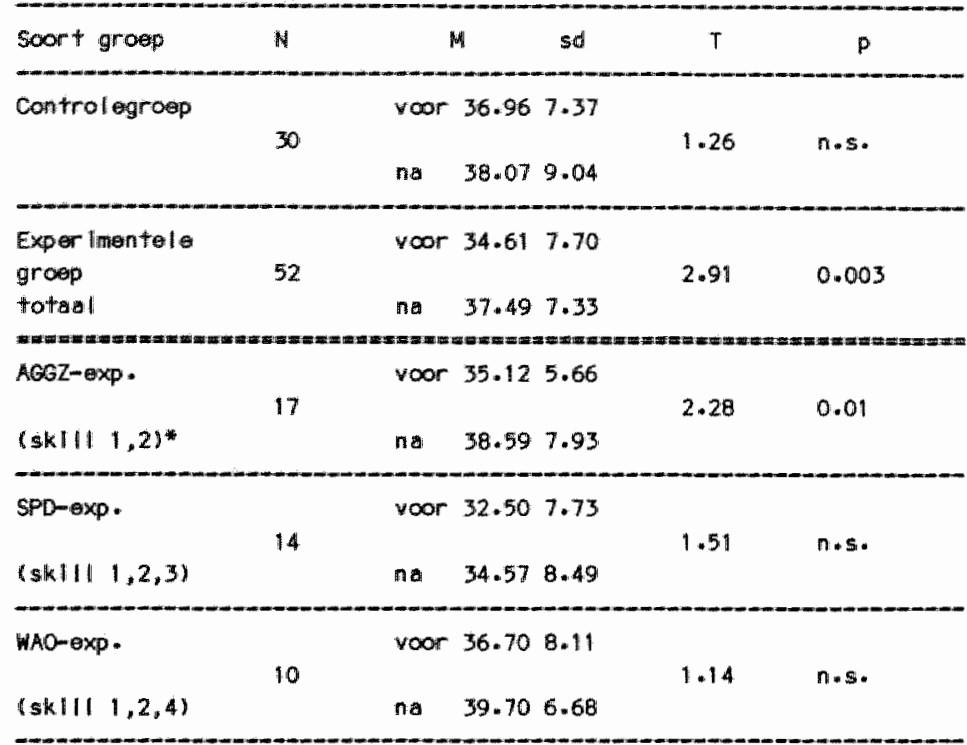

* skill 1 = degelljkse problemen aenpakken

sk III 2 = verander Ingen anpakken

sklII 3 - besillss Ingen nemen

sklll 4 = Informatle verzamelen

Tabel 7.5. laat significante verschillen zien tussen tussen voor- en nameting bij de AGGZ-groep en bij de experimentele groep totaal. Beide groepen blijken bij de nameting significant toegenomen m.b.t. Interne controle.

Wat de controlegroep betreft, kan men geen significant verschil tussen voor- en nameting constateren.

7.6.5. Effecten ten aanzien van zelfwaardering

Wat de SE-schaal betreft, zijn 41 experimentele en 28 controlemetingen verzameld. Beide groepen verschillen niet significant van elkaar op de voormeting $(T=1.04 ; n . s$.$) .$

Tabe1 7.6. geeft een overzicht van de gevonden verschillen tussen voor- en nameting wat betreft zelfwaardering ten aanzien van experi- 
mentele en controlegroep. Wat de experimentele groep betreft, worden de resultaten total en per subgroep weergegeven.

Bij de AKG-groep werden geen gegevens ten aanzien van zelfwardering verzameld.

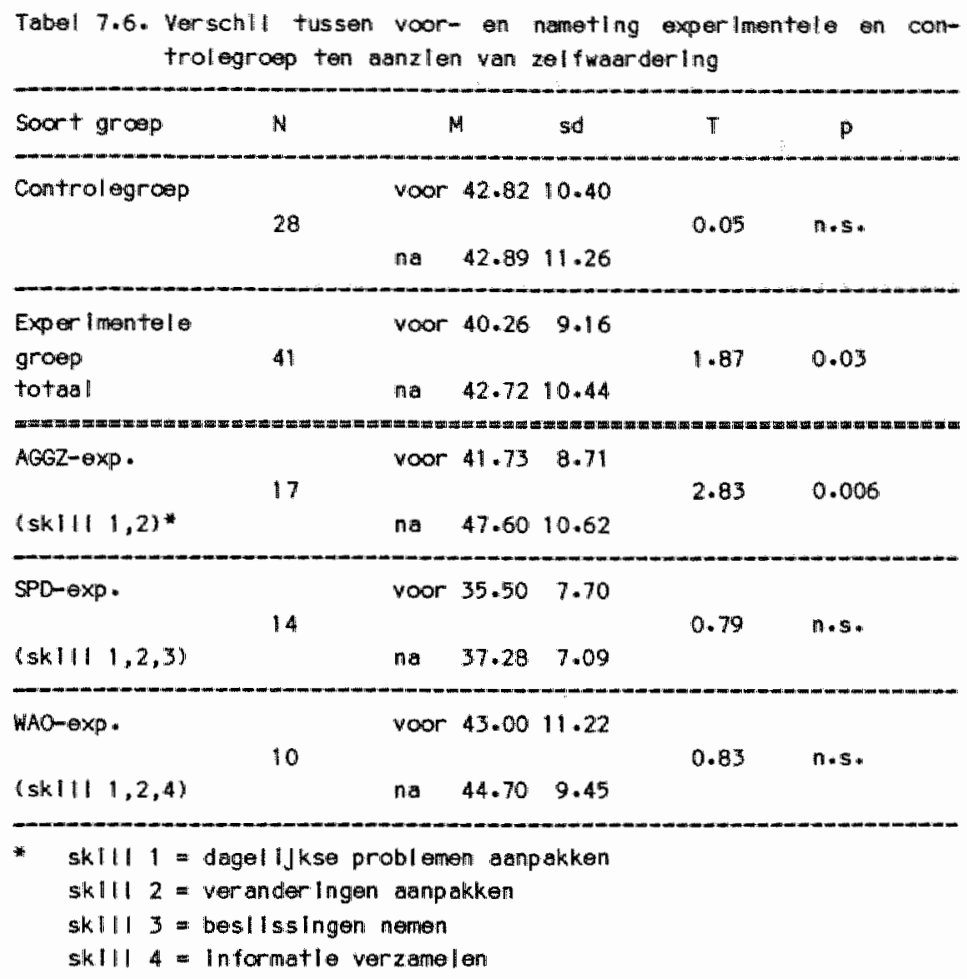

Tabel 7.6. toont significante verschillen tussen woor- en nameting bij de AGGZ-groep en bij de experimentele groep total. Beide groepen blijken bij de nameting over significant meer zelfwardering te bew schikken.

Wat de controlegroep betreft, kan men geen significante verschillen tussen voor - en nameting constateren. 
Wat de rigiditeftsschaal betreft, zijn 52 experimentele en 30 controle-metingen verzameld. Beide groepen verschillen niet significant van elkaar op de voormeting $(T=1.57$; n.s.).

Tabe1 7.7. geeft een overzicht van de gevonden verschillen tussen voor- en nameting wat betreft rigiditeit ten aanzien van experimentele en controlegroep. Wat de experimentele groep betreft, worden de resultaten total 1 en per subgroep weergegeven.

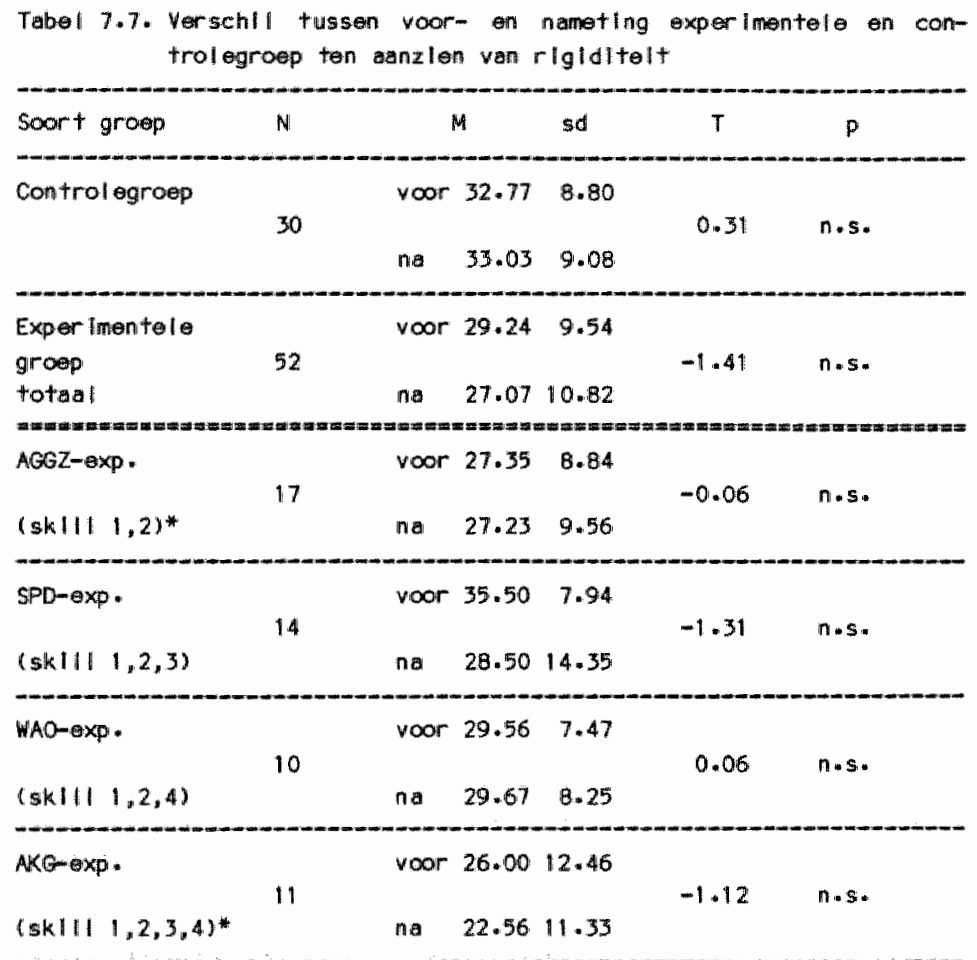

- skllı I = dagelljkse problemen ampakken

skl|| 2 - verander Ingen aanptkken

skll| 3 = basilissingen namen

skll 4 Informatle verzamelen

Tabel 7.7. toont geen significante verschillen tussen voor- en nameting wat betreft rigiditeit: voor de experimentele groep noch voor de control egroep. 
7.6.7. Effecten ten aanzien wan copingstijlen

Wat de $U C L$ betreft, zijn de subschalen $U C L_{1}$ en $U C L_{3}$ relevant. Ten aamzien van elk van beide subschalen werden 41 experimentele en 28 controlemetingen verzameld. UCL 1 verwijst naar de copingstij1 "aanpakken" als reactie op problemen. $\mathrm{UCL}_{3}$ naar de copingstijl "afwachten/vermijden" als reactie op problemen.

Wat $U C L_{1}$ en $U C L_{3}$ betreft, kan men geen significante verschillen constateren bij de voormeting tussen de experimentele groep en de controlegroep. Voor $U C L_{1}$ geldt $T=0.28$, n.s. Woor $U C L_{3}$ geldt $T=0.07, n . s$.

Tabel 7.8. geeft een overzicht van de gevonden verschillen tussen voor- en nameting wat betreft $U C L_{1}$ en $U C L_{3}$ ten aanzien van experimentele en controlegroep. Wat de experimentele groep betreft, worden de resultaten totaal en per subgroep weergegeven.

Bij de AKG-groep werden geen UCL-data verzameld.

\begin{tabular}{|c|c|c|c|c|c|c|}
\hline Soort groop & N & & $M$ & sd & T & $\mathrm{p}$ \\
\hline Contralegroep & 28 & $\begin{array}{l}\text { UCL, voor } \\
\text { UCL, na } \\
\text { UCL, }_{3} \text { voor } \\
\text { UCL, na }_{3} \text { na }\end{array}$ & $\begin{array}{l}21.03 \\
19.89 \\
12.43 \\
13.29\end{array}$ & $\begin{array}{l}3.79 \\
4.08 \\
2.74 \\
2.48\end{array}$ & -2.13 & 0.04 \\
\hline $\begin{array}{l}\text { Exper Imentele } \\
\text { groep totaall }\end{array}$ & 41 & $\begin{array}{l}\mathrm{UCL} \text {, voor } \\
\text { UCL, no } \\
\mathrm{UCL}_{3} \text { noor } \\
\mathrm{UCL}_{3} \text { no }\end{array}$ & $\begin{array}{l}21.59 \\
20.87 \\
12.57 \\
12.27\end{array}$ & $\begin{array}{l}4.22 \\
4.96 \\
3.36 \\
2.97\end{array}$ & $\begin{array}{l}-1.02 \\
-0.83\end{array}$ & n.s. \\
\hline $\begin{array}{l}A G G Z-\exp . \\
(s k|1| 1,1,2)\end{array}$ & 17 & $\begin{array}{l}\text { UCL, voor } \\
\text { UCL, no } \\
\mathrm{LCL}_{3} \text {, voor } \\
\mathrm{UCL}_{\text {, na }} \text { na }\end{array}$ & $\begin{array}{l}23.24 \\
22.12 \\
10.87 \\
11.80\end{array}$ & $\begin{array}{l}x=18=13 \\
4.78 \\
5.48 \\
2.45 \\
3.14\end{array}$ & $\begin{array}{l}-0.97 \\
-0.90=0\end{array}$ & n.s. \\
\hline $\begin{array}{l}\text { SPD-exp. } \\
(\text { sk } 1111,2,3) *\end{array}$ & 14 & $\begin{array}{l}\text { UCL, roor } \\
\text { UCL, no } \\
\text { UCL, roor } \\
\text { UCL, ne }\end{array}$ & $\begin{array}{l}20.85 \\
20.62 \\
12.31 \\
12.23\end{array}$ & $\begin{array}{l}3.53 \\
4.70 \\
4.44 \\
3.22\end{array}$ & $\begin{array}{l}-0.16 \\
-0.12\end{array}$ & n.s. \\
\hline
\end{tabular}




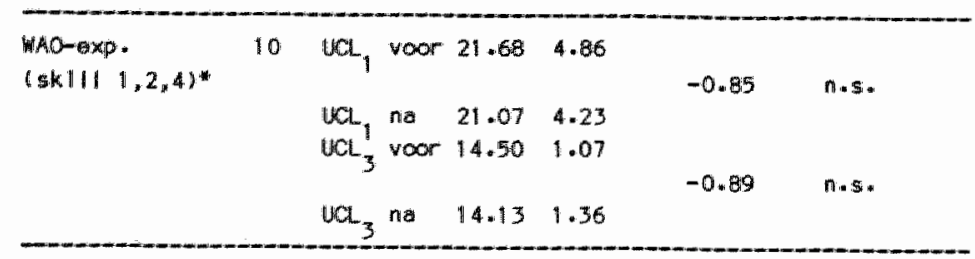

- skll| I dagel ljkse problenen anpakken

skl\| 2 werrander lingen aumpikken

skI\|I 3 besllsslingen nemen

sik $1 \| 1.4$ Informatle verzamelen

Tabel 7.8. toont geen significante verschillen tussen voor- en nameting wat betreft $U \mathrm{UL}_{1}$ en $U \mathrm{UCL}_{3}$ ten aanzien van de experimentele groep. Wat de controlegroep betreft, kan men een significante achteruitgang tussen voor- en nameting constateren ten aanzien van $U C L_{1}$.

7.6.8. Effecten bij herhaalde meting na een jaar

Ongeveer een jaar na deelname zijn 41 ex-deelnemers aan de experimentele conditie uitgenodigd voor een tweede nameting. Daarbij werd van 7 proefpersonen geen medewerking verkregen, terwijl 1 ex-deelnemer onbereikbaar bleek ondanks twee pogingen tot schriftelijke contactname.

De 7 individuen die van hun medewerking afzagen, noemden als redenen daartoe:

- tijdgebrek

- ziekte

- niet herinnerd willen worden aan eerdere levensperiode.

$B\{j$ de 33 mensen die wel hun medewerking verleenden, werden dezelfde data verzameld als bij de eerste nametïng. Deze 33 personen makten deel ult van de AGGZ-subgroep, de SPD-subgroep en de WAO-subgroep. Bij de AKG-groep werden geen follow-up gegevens verzameld.

Nagegaan werd of de bij de experimentele groep bereikte resultaten gehandhaafd bleven tijdens de follow-up periode.

In tabe 1 7.9. worden de verschillen tussen nameting 1 en nameting 2 op mogel ijke significantie getoetst. 
Tabel 7.9. Verschll tussen nameting 1 en now ing 2

\begin{tabular}{|c|c|c|c|c|c|}
\hline Meet in str unvent & Namet Ing & $M$ & std & $T$ & $\mathrm{p}$ \\
\hline $\mathrm{DH}_{1}$ & $\begin{array}{l}1 \\
2\end{array}$ & $\begin{array}{l}6.03 \\
6.51\end{array}$ & $\begin{array}{l}3.90 \\
4.68\end{array}$ & 0.87 & $n \cdot s *$ \\
\hline $\mathrm{DH}_{2}$ & $\begin{array}{l}1 \\
2\end{array}$ & $\begin{array}{l}7.88 \\
9.48\end{array}$ & $\begin{array}{l}2.09 \\
1.75\end{array}$ & 2.63 & 0.01 \\
\hline $\mathrm{DH}_{3}$ & $\begin{array}{l}1 \\
2\end{array}$ & $\begin{array}{l}7.69 \\
7.82\end{array}$ & $\begin{array}{l}2.36 \\
2.73\end{array}$ & 0.41 & $n \cdot s$. \\
\hline IE & $\begin{array}{l}1 \\
2\end{array}$ & $\begin{array}{l}37.09 \\
37.76\end{array}$ & $\begin{array}{l}7.65 \\
7.74\end{array}$ & 0.57 & $\pi \cdot s$ \\
\hline SE & $\begin{array}{l}1 \\
2\end{array}$ & $\begin{array}{l}43.29 \\
46.19\end{array}$ & $\begin{array}{r}8.67 \\
12.76\end{array}$ & 1.49 & $\mathrm{fH} * \mathrm{~s} *$ \\
\hline $\mathbb{R G}$ & $\begin{array}{l}1 \\
2\end{array}$ & $\begin{array}{l}27 \cdot 04 \\
28.43\end{array}$ & $\begin{array}{l}11.17 \\
9.22\end{array}$ & 0.28 & $\mathrm{n} \cdot \mathrm{s}$. \\
\hline UCL, & $\begin{array}{l}1 \\
2\end{array}$ & $\begin{array}{l}19.59 \\
20.86\end{array}$ & $\begin{array}{r}4.17 \\
3.99\end{array}$ & 2.12 & 0.04 \\
\hline $\mathrm{HaL}_{3}$ & $\begin{array}{l}1 \\
2\end{array}$ & $\begin{array}{l}12.71 \\
12.68\end{array}$ & $\begin{array}{l}2.77 \\
2.96\end{array}$ & -0.09 & n.s * \\
\hline
\end{tabular}

Tabel 7.9. toont dat de tijdens de experimentele periode bereikte vooruitgang stabiel blijft. Ten aanzien van $\mathrm{DH}_{2}$ en $\mathrm{UCL}_{1} k$ an men bij nameting 2 een significante vooruitgang constateren. Deze vooruitgang was niet aantoonbaar bij nameting 1 .

\subsection{SAMENVATTING}

Op vastgestelde tijdstippen werden door middel van een voormeting en twee nametingen uitkomst-gegevens verzameld bij een aantal clienten die deelnamen aan persoonlijke vaardigheldstherapieên en bij een aan- 
tal clienten die op de wachtlijst stonden voor deelname aan persoonlijke vardigheidstherapieën. Tijdens de wachtperiode liep de individuele behandeling bij de doorverwijzende hulpverleners normaal door. Deze gegevens werden verzameld teneinde de vraag naar de effectivitelt van de ontwikkelde persoonlijke vaardigheidstheraple-programma's te kunnen beantwoorden. Deze programma's werden toegepast bij LIBO-clienten. Al deze clienten waren in behandeling bij eem ambulante danwel klinische instelling voor geestelijke gezondheidszorg. De totale experimentele groep kan worden onderverdeeld in een AGGZ-groep, een SPDgroep, een WAO-groep en een AKG-groep (voor een nadere toelfichting zie 7.4.1.).

De gehanteerde uitkomst-criteria kan men onderverdelen in algemene psychologische criteria, afgeleid uit de in hoofdstuk 5 beschreven relevante theoretische ontwikkelingen en specifieke criteria geoperationaliseerd met behulp van de in hoofdstuk 6 beschreven vragenlijst "Doellmatig Handelen".

Deze vragenlijst bleek wit 3 subschalen te bestaan:

- vertrouwen in eigen probleemoplossingsvaardigheld $\left(\mathrm{DH}_{1}\right)$

- plannen en vooruitdenken $\left(\mathrm{DH}_{2}\right)$

- consequent handelen $\left(\mathrm{DH}_{3}\right)$.

Ten aanzien van de controlegroep geldt dat er geen significante verschillen tussen voor- en nameting aantoonbaar zijn.

Voor de totale experimentele groep geldt dat men significante verschillen tussen voor- en nameting kan constateren ten aanzien van $\mathrm{DH}_{1}$ en $\mathrm{DH}_{3}$. Ditzelfde geldt ook voor subgroep 1: de AGGZ-groep. Wat de overige subgroepen betreft - SPD, WAO, AKG - blijken geen significante verschillen tussen voor- en nameting aantoonbaar.

Deelname aan persoonlijke vaardigheidstherapleën blijkt dus alleen entg resultaat te hebben bij deelnemers uit subgroep 1: de clienten met milde, psychosociale problematiek.

Bif de 3 overige subgroepen, allen clienten/patienten met zwaardere psychische problematiek, zijn geen significante resultaten aantoonbaar.

Als algemene, psychologische uitkomstcriteria zijin de IE-schaal, de SE-schal, de rigiditeitsschaal uit de NPV en de subschalen 1 en 3 uit 
de Utrechtse coping Lijst gehanteerd. Bij de experimentele groep totaal zijn significante verschillen tussen voor- en nameting aantoonbaar ten aanzien van IE en SE.

Ditzelfde geldt ook voor subgroep 1: de AGGZ-groep. Wat de overige subgroepen betreft - SPD, WAO, AKG - blijken geen signficante verschillen tussen voor- en nameting aantoonbaar.

Weer geldt dat alleen enig resultaat aantoonbaar is bij deelnemers uit subgroep 1: de clienten met milde, psychosociale problematiek. Bij de 3 overige subgroepen, allen clienten/patienten met zwaardere psychische problematiek, zijn geen significante resultaten aantoonbaar. Wat de controlegroep betreft, kan men alleen significante verschillen tussen voor- en nameting constateren ten aanzien van $U C L_{1}$. Bij de nameting blijken de proefpersonen significant minder gebruik te maken van de copingstijjl "aanpakken" als reactie op problemen dan bij de voormeting.

Wat de experimentele groep betreft, is er een herhaalde nameting uitgevoerd een jaar na deelname aan persoonl ijke vaardigheidstherapieën. Bij deze herhaalde nameting blijkt dat de tijdens deelname aan persoonlijke vaardigheidstherapieën bereikte resultaten stabiel blijven tijdens de follow-up periode. Ten aanzien van $U \mathrm{CL}_{1}$ kan men tijdens deze periode een significante vooruitgang constateren. Deze vooruitgang bleek niet aanwezig bij nameting 1 .

In hoofdstuk 8 worden de hier beschreven resultaten van discussie voorzien. 
HOOFDSTUK 8. CONCLUSIES EN DISCUSSIE

\subsection{INLEIDING}

In hoofdstuk 8 worden de belangrijkste conclusies uit dit proefschrift samengevat en van discussie voorzien. Achtereenvolgens zal aandacht worden besteed aan de relatie tussen psychotherapie en lagere sociaaleconomische klasse; de rellatie tussen persoonlijke en interpersoonlijke vaardigheidstherapieën; de cognitieve ontwikkelingen in de gedragstheraple; het geintegreerd cognitief sociaal-leertheoretisch mode1; het effectiviteitsonderzoek en de wijze waarop de persoonlijke vaardigheidstherapieën worden uitgevoerd.

8.2. PSYCHOTHERAPIE MET CLIENTEN UIT DE LAGERE SOCIAAL-ECONOMISCHE KLASSEN

Sinds de formatie van de Goldsteinprojectgroep heeft de toepassing van met name de interpersoonlijke vaardigheidstherapieèn een grote v1ucht genomen. De ervaringen tot nu toe bevestigen dat de ontwikkeling en implementatie van een kortdurende psychotherapie-methode speciaal afgestemd op de psychologische kenmerken en eigenschappen van LIBOclienten vrucht heeft afgeworpen. De ontwikkelde methode blijkt in een bestaande behoefte te voorzien, niet alleen in Zuid-Limburg maar inmiddels ook in de rest van Nederland en in België. Ze wordt inmiddels in tal van instellingen voor ambulante en $\mathrm{klinische}$ geestelijke gezondheidszorg toegepast.

In de zeventiger jaren werd in de nationale en intermationale vakliteratuur uitgebreid aandacht besteed aan het psychotherapeutisch werk met clienten uit de lagere sociaal-economische $k l$ assen. Deze aandacht blijkt in de tachtiger jaren enigszins gekenterd mede onder invioed van socilal-economische ontwikkelingen. 
$\mathrm{Mr}$. Hound, met als profielkenmerken humble, old, unattractive, nonverbal en dull - conform schofield (1964) het prototype van de LIBOclient - heeft evenveel recht op psychotherapeutische behandeling als Mr. Yavis. Mr. Yavis met als profielkenmerken young, attractive, verbal, intelligent, successful, vormt het prototype van de client uit de midden en/of hogere klassen. Naast ontwikkeling, evaluatie en bijstelling van behandelingsalternatieven, aangepast aan de psychologische kenmerken en eigenschappen van LIBO-clienten, dient ook aandacht te worden besteed aan de wijze waarop klasse-bepaalde verschillen in houding en verwachtingspatroon - tussen client en therapeut het verloop van het (psycho)therapeutisch behandelingsproces kunnen beinvloedem. Het is van belang dat (psycho)therapeuten dergelijke verschillem tijjig leren signaleren, hanteren en in het door hen opgestelde behandelingsplan verdisconteren.

Lange (1984) toonde nogmaals aan dat öók in Nederland geldt, dat de sociaal-economische achtergrond van een client bepaalt in welk ambulant dan wel klinisch, (sociaal) psychiatrisch dan wel psychotherapeutisch - behandelingskamaal hij terecht komt en niet de aard en ernst van zijin psychische, psychosomatische en/of psycho-sociale problematiek.

\subsection{PERSOONLIJIKE EN INTERPERSOONL IJKE VAARDIGHEIDSTHERAPIEEN}

Goldstein (1973) is van mening dat men bij het aanteren van vaardigheden een onderscheid dient te maken tussen interpersoonlijke vaardigheden en persoonlijke vaardigheden. Effectief functioneren vooronderstelt de aamwezigheid van belde soorten vaardigheden in het copingrepertoire van het individu. In navolging van Goldstein besloot de Mastrichtse projectgroep naast een serie interpersoonlijke vaardigheidstherapieën ook een serie persoomlijke vaardigheidstherapieën te ontwikkelen.

Bïj deze persoonlljke vaardigheidstherapleën ligt de nadruk vooral op het aanleren van coverte gedragsaspecten. Wamneer de deelnemers aan deze vaardigheidstherapieën deze coverte gedragsaspecten, ook wel denkstappen genoemd, voldoende beheersen, betekent dat niet dat zij 
ook automatisch de interpersoonlijke vaardigheden ter beschikking hebben, die bij de ultwoeringsfase van elk van de vier persoonlijke vaardigheden van belang zijim. Tekorten en/of excessen in interpersoonlijk gedrag kunnen tot gevolg hebben dat het in praktijk brengen van de persoonl ijke vaardigheden bemoeil ijkt wordt.

Persoonlijke en interpersoonlijke vaardigheden kunnen dus niet als afzonderlijke entiteften worden opgevat: beide vooronderstelien elkaar en vullen elkaar aan. Deelname aan de hier beschreven persoonlijke vaardigheidstherapleën veronderstelt de aanwezigheid van basale interpersoonlijke vaardigheden in het gedragsrepertaire van het betreffende individu. Wanneer dergelijke vaardigheden niet in het gedragsrepertoire aanwezig ziljn, is deelname aan interpersoonlijke vaardigheidstherapieën aangewezen vooraf aan deelname aan persoonlijke vaardigheidstherapleën.

Tijdens persoonlijke vaardigheidstherapieën wordt wooral aandacht besteed aan het inoefenen van covert gedrag. Er wordt geen, voor de betreffende persoon nieuw en onbekend, interpersoonlijk gedrag ingeoefend. Persoanlijke vaardigheidstherapleën zijn dus met name geindiceerd bij die clienten met tekorten in probleemoplossend gedrag die over voldoende basale interpersoonl ijke vaardigheden beschikken.

Bij de indicatiestelling voor deelname aan persoonlijke vaardigheidstherapieën dient derhalve de beoordeling van het interpersoonlijke vaardigheidsniveau van het betreffende individu te worden betrokken. Het interpersoonlijke vaardigheidsniveau kan worden vastgesteld met behuip van de door de Goldsteinprojectgroep ontwikkelde interpersoonlijke vaardigheidsmeters, ook we1 skitimeters of skims genoemd. Deze vaardigheldsmeters hebben de vorm van korte schriftelijke vragemijsten in multiple-chofce vorm (zie Beekers, 1982). Voor de beoordeling van het persoon 1 ijke vaardigheidsniveau kan gebruik gemaakt worden van de in hoofdstuk 6 beschreven DH-1 ljst nadat deze voldoende is genormeerd. Overigens liggen op het gebied van de complexe samenhang tussen persoonlijke en interpersoonlijke vaardigheden nog vele (onderzoeks)vragen open.

Wat de persoonlijke en interpersoonl1.jke vaardigheidstherapieën betreft, kan men constateren dat bij beide sprake is van beĩnloeding van covert zowel als overt gedrag. Bij de persoonilike vaardigheids- 
therapieën 1 igt de nadruk op het aanleren van covert gedrag en bij de interpersoonlijke vaardigheidstherapleën op het aanleren van overt gedrag.

De term "persoonlijke" vaardigheidstherapieën impliceert dat er sprake is van het aanleren van vaardigheden die primair betrekking hebben op de omgang van het individu met zichzelf. Dit in tegenstelling tot de "interpersoonlijke" vaardigheidstherapieën die primair betrekking hebben op het aanleren van vaardigheden in de omgang met anderen. Ten aanzien van zowel persoonlijke als interpersoonl ijke vaardigheidstherapieën à la Goldstein, kan men constateren dat er nogal wat LIBOclienten voor deelname worden aangemeld met een combinatie van persoonlijke en interpersoonlijke vaardigheidstekorten. Bij deze clientcategorie is moeilijk te bepalen welk van beide typen vaardigheldstekorten het eerst moet worden opgeheven. Wellicht dat voor deze groep clienten deelname aan een vaardigheidstherapieprogramma warin persoonlijke en interpersoan 1 ijke vaardigheden nast elkaar worden ingeoefend, de voorkeur verdient boven successfevelijke deeiname aan een serie specifieke persoonlijke danwel interpersoonlijke vaardigheidstherapleën na elkaar in de tijd. De in hoofdstuk 2 beschreven probleemoplos-1iteratuur kan bij de ontwikkeling van een dergelijk programna behulpzaam zijn.

\subsection{DE COGNITIEVE ONTWIKKELINGEN IN DE GEDRAGSTHERAPIE}

Zowel ten aanzien van theorievorming ais psychotherapeutische praktijk kan men sinds de zestiger jaren in de gedragstherapie een toenemende trend in cognitieve richting onderscheiden. In 4.2.3. werden bij deze ontwikkeling een aantal kanttekeningen geplaatst. De cognitieve theorievorming lijkt vooralsnog in de kinderschoenen te staan. Bij de empirische onderbouwing daarvan blijken cognities onduidelijke en moei1 ijk operationaliseerbare variabelen.

In de psychotherapeutische praktijk riepen begrippen als cognitie, cognitief, cognitieve (gedrags)therapie lange tijd weerstand op. Onder praktiserende psychotherapeuten lijkt vooralsnog de mening te overheersen dat enerzijds gevoelens en de beinnloeding daarvan het cen- 
trale aandachtspunt dienen te vormen van psychotherapie en dat anderzijds aandacht voor cognitieve aspecten en processen het risico met zlch brengt van ratfonallsatie en verdringing van emoties met alle negatieve gevolgen vandien.

In de experimentele sociale psychologie en in het experimenteell onderzoek ten aanzien van leerprocessen kamt echter steeds duidelijker de belangrijke rol naar voren van cognitieve verwerkingsprocessen - in de vorm van attributfes, etiketteringen en warderingen - bij het tot stand komen van (menselijk) gedrag. Deze bevinding heeft consequenties voor de psychotherapeutische praktijk. De pertode van eenzijdige verheerlijking van het primaat van de emoties en het negeren van cognitieve factoren lijkt hiermee teneinde. Wanneer dit primat echter alleen maar wordt ingewisseld voor een even eenzijdige verheerlijking van cognitieve aspecten en processen, betekent dat geen winst. Zoals bif menselijk functioneren in het algemeen de balans tussen cognitieve processen en aspecten enerzijds en belevingen en emoties anderzijds in evenwicht dient te zijn, evenzo spelen bij het herstel daarvan in psychisch opzicht mutatis mutandis dezelfde processen en aspecten een rol.

Dok al is het inzicht in de rol van cognitieve processen bij ontstaan en instandhouding van emoties groeiende, toch behoeft de wijze waarop cognitie, emotie en gedrag met elkaar interacteren nog het nodige empirisch onderzoek.

Dok wat de cognitieve gedragstherapeutische interventies betreft, is vooralsnog onduidelljk wat de relatieve bijdrage is van cognitieve versus gedragsgerichte technieken in het therapeutisch veranderingsproces. Boelens en Debats (1983) kwamen bij onderzoek van depressieve patienten tot de conclusie dat een combinatie van gedragsgerichte en cogmitieve interventies de beste resultaten oplevert. Op basis van een door hen uitgevoerde meta-analyse met betrekking tot de effecten van Rationeel Emotieve Theraple - een cognitieve theraple-methode ontworpen door Ellis (1970) - kwamen Engels en Diekstra (1986) tot de conclusie dat een combinatie van cognitieve technieken en gedragsgerichte interventies in een en dezelfde behandeling geen betere resultaten oplevert dan een louter uit cognitieve interventies bestaande behande1ing. Uit bovenstaande blijkt dat er in de literatuur onenigheid 
bestaat over het feit of het nu wel of niet effectief is cognitieve technleken en gedragsgerichte interventies in ë̈n behandeling te conbineren. De in dit apzicht beschikbare onderzoeksresultaten leiden duidelijk tot tegenstrijdige conclusies. Engels en Diekstra (1986) zijn van mening dat een gecombineerde behandeling te hoge eisen stelt aan de deskundigheid en vardigheden van therapeuten en daardoor minder effectief blijkt.

De in hoofdstuk 5 beschreven theoretische ontwikkelingen impliceren dat bij elke vorm van gedragsveramdering en dus ook bij ledere vorm van gedragstherapie cognitieve verwerkingsmechanismen een rol spelen. Het is derhalve de vraag of de subclassiflicatie "cognitieve gedragstherapie" niet eerder verwarring schept dan dat ze enige verheldering oplevert. Elke vorm van gedragstheraple heeft immers betrekking op de complexe wissellwerking tussen de beînvloeding van emoties, cognities en (overt) gedmag. Een louter cognitivistische benadering in deze is even beperkt en eenzijdig als een louter behavioristische benadering.

\subsection{HET GEINTEGREERD COGNITIEF SOCIAAL-LEERTHEORETISCH MODEL}

Het in hoofdstuk 5 gepresenteerde geintegreerd cognitief soclaal-leertheoretisch model vormt een poging de interactie persoon-situatie zodanig weer te geven dat verwachtingsconcepten en andere cognitieve beoordelingsprocessen aan elkaar gerelateerd kunnen worden. De door Rotter (1954), Lazarus (1966) en Bandura (1977) geschetste theoretische modellen vormen de bouwstenen waaruit het geintegreerd model is opgebouwd. De modellen van Rotter, Lazarus en Bandura blijken complementair aan elkaar respectief onderling verenigbaar.

De door Bandura (1977) ontwikkelde "self-efficacy"-theorie bledt een bruikbaar theoretisch verklaringsmodel voor de wijze warop persoonlijke danwel interpersoonlijke vaardigheidstherapieèn het vertrouwen in eigen kunnen van de deelnemers bevorderen. Toename van dit vertrouwen blijkt tot gevalg te hebben dat individuen niet langer gevangen blijven in een spiraal van faalerwaringen ten aanzien van de betreffende vaardigheid met alle gedragsinhiberende gevolgen vandien. Uit Bandura's self-efficacy-theorie zijn de in hoofdstuk 5 beschreven 
implicaties afgeleid yoor de wijze warop (vaardigheids)therapieen worden uftgevoerd. Voordeel van deze theorie is dat daarin cognitileve processen en (sociale) omgevingsinvioeden als gedragsdeterminanten in aaninerking worden genomen.

Bandura is van mening dat persoonlijke competentle-verwachtingen en respons-uitkomst-verwachtingen de belangrijkste gedragsdeterminanten vormen. Hij is bovendien van meming dat beide soorten verwachtingen onafhankelijk zijn van elkaar. Eastman en Marzillier (1984), Marzillier en Eastman (1984) echter stellen dat beide soorten verwachtingen niet onafhankelijk zijn van elkaar maar onderling gerelateerd. De controverse tussen de opvattingen van Bandura en die van Eastman en Marzillifer zal door nader empirisch onderzoek moeten worden beslecht.

In de theorie van Rotter (1954) ligt de nadruk op de uitwerking van het begrip reinforcement-waarde. In de theorie van Bandura ligt de nadruk op de uitwerking van het begrip persoonlijke competentie-verwachting. Het begrip respons-uitkomst-verwachting wordt wel genoemd maar niet nader uitgewerkt. De wijze waarop Rotter het begrip reinforcement-waarde uitwerkt, kan als een nadere operationalisatie en concretisering van het door Bandura gehanteerde begrip respons-uitkomst-verwachting worden opgevat.

Het door Lazarus (1966) ontwikkelde stressmodel benadrukt het belang van cognitieve beoordelingsprocessen bij het hanteren van als (be)dreigend ervaren situaties. Het aan dit model ontleende coping-concept neemt een belangrijke plaats in in psychologische theorie-vorming zowel als psychotherapeutische praktijk. Coping vormt, aldus Jaspers (1980), een speciale vorm van aanpassing waarbij geen gebruik wordt gemaakt van vertrouwde, routine-matig aanwezige gedrags- en reactiepatronen. Deze worm van aanpassing is aangewezen in situaties gekenmerkt door een grote mate van (be)dreiging en onzekerheid. Over de wijze waarop het concept coping dient te worden geoperationaliseerd, bestaat weinig overeenstemming (Schreurs e.a. 1984). Kernvraag daarbij is of dit concept op algemeen ("trait") danwel specifiek ("state")niveau gemeten dient te worden. De in dit proefschrift toegepaste operationalisatie in de worm wan de Utrechtse coping Lijst (Schreurs 
e.a., 1984) vomt een meting op "trall"-niveau. Doel van de toegepaste meetmethode is een overzicht te verkrijgen van de mate warin het individu gebruik makt wan een voorgegeven aantal copingstijlen. In het hier beschreven onderzoek worden 5 van de door Schreurs e.a. (1984) behandelde copingstijlen in aanmerking genomen, te weten:

1. vermijden, afwachten

2. steun zoeken

3. aanpakken als reactie op spanning(en)

4. afleiding zoeken

5. Jezelf geruststellen, relativeren.

Conform Lazarus" opvatting ten aanzien van een adequat copingrepertollre veronderstelt effectief persoonlijk functioneren de aanwezigheid van instrumentele en palliatieve copingfuncties. De tem instrumenteel verwijst naar copingwijzen gericht op directe verandering van de spanning-oproepende situatie. De term palliatief verwijst naar copingwijzen gericht op emotie-regulatie. Beide soorten copingfuncties kumnen zeer adaptief zijn in spanningsbeladen situaties, zonder dat de ene soort op zich geestelijk gezonder en/of effectiever genoend kan worden dan de andere. De interactie persoon-situatie bepalt welk van beide copingfuncties in een concrete situatie het meest haalbaar en adaptief is. Een adequat copingrepertoire veronderstelt niet alleen de aanwezigheid van beide soorten copingfuncties maar ook een zekere mate van flexibiliteit in de toepassing daarvan. Een gemis aan flexibiliteit in deze wordt we 1 als kenmerkend gezien voor het ontstaan van psychopathologie (B. Bakker, 1983 ).

Het lijkt zinvol na te gaan of men ten aanzien van coping en coplingstijlen een soortgellijk indelingssysteem en bijpassend meetinstrument zou kunnen ontwikkelen als Leary (1957) ontwierp ten aanzien van interpersoonlijk gedrag. Een dergellik systeem heeft als voordeel dat nast kwalitelt van gedrag ook kwantiteit en flexiblliteft daarvan in kaart gebracht worden. Met behulp van een dergel1jk instrument zou men eventule tekorten en excessen ten aanzien van specifileke instrumentele danwel palliatileve copingstijlen kunnen signaleren. Het overzicht over deze tekorten en/of excessen zou dan vervolgens als richtiljn kunnen dienen bij het opstellen van een psychotherapeutisch behande- 
lingsplan, gericht op herstel, uitbreiding en flexibllisering van het copinggedrag. Een dergelijke wijze van probleem-analyse komt de hol istische benadering van het functioneren van indidivuen ten goede en voorkomt een louter $k l$ achtgerichte aanpak.

In het in hoofdstuk 5 beschreven geintegreerd cognitief sociaal-leertheoretisch model worden de theorieën van Bandura, Rotter en Lazarus aan elkaar gekoppeld. Dit model biedt de mogelijkhejd de tijdens deelname aan persoonlijke vaardigheidstherapieën optredende leerprocessen afdoende te verklaren. Uit dit model zijn de volgende doelstellingen voor (vaardighelds) therapieën af te leiden:

- verhoging en generalisering van de persoonlijke competentie-verwachtingen van de deelnemers.

- optimalisering van de respons-uitkomst-informatie bij de deelnemers.

- bevordering van realistische appraisal-processen.

Voortgezet onderzoek is nodig ter nadere empirische toetsing van het in hoofdstuk 5 gepresenteerde cognitief sociaal-leertheoretisch model.

\subsection{HET EFFECTIVITE ITSONDERZOEK}

Het in hoofdstuk 7 beschreven effectiviteitsonderzoek had betrekking op vier subgroepen LIBO-clienten, te weten: een AGGZ-groep, een SPDgroep, een AKG-groep en een WAO-groep. Voor een nadere beschrijuing van deze subgroepen zie 7.4.1.

De resultaten werden gepresenteerd over de totale groep en per subgroep. Wat de totale groep en de AGGZ-subgroep betreft, kan men significante verschillen tussen voor- en nameting constateren op 2 van de 3 specifieke uitkomstcriteria $\left(\mathrm{DH}_{1}\right.$ en $\left.\mathrm{DH}_{3}\right)$ en op 2 van de 5 algemene uitkomstcriteria (SE en IE).

Wat de drie psychiatrisch georiënteerde subgroepen betreft, kain men geen enkel significant verschil tussen voor- en nameting constateren. Bovenstaande leidt tot de conclusie dat de hier beschreven persoon1 ijke vaardigheidstherapieën met enig resultaat kunnen worden toegepast bij LIBO-clienten in de ambulante, geestelijke gezondheidszorg bij wie sprake is van milde psychosociale problematiek. 
Bij LIBO-clienten met zwaardere problematiek, van meer psychiatrische aard, blijken de persoonlijke vaardigheidstherapieën geen enkel effect te sorteren.

De door Goldstein ontworpen vaardigheidstherapieën hadden ten doel de problemen in de psychotherapeutische hulpverlening aan clienten uit de lagere sociaal-economische klassen op te lossen. Uit het hier beschreven onderzoek naar de effecten van de in Masstricht ontwikkelde variant, werd duidelijk dat:

- de door Goldstein ontwikkelde vaardigheidstherapieën vooral effectief blijken bij een subgroep LIBO-clienten met millde, psychosociale problematiek. (Zie ook Beekers, 1982.)

- de interpersooni ijke vaardigheidstherapieën meer resultaten opleveren dan de hier beschreven persoonlijke vaardigheidstherapieën. (Zie ook Beekers, 1982.)

Goldstein's optimisme ten aanzien van de effectiviteit van de door hem ontwikkelde leermethode bl ijkt dus niet geheel gerechtvaardigd. De methode blijkt immers vooral effectief bij LIBO-clienten met milde, psychosociale problematiek die nog voldoende zijn opgenomen in het algemeen sociaal-maatschappelijk verkeer. Voor deze clientcategorie geldt dat er sprake is van meer motivatie om vaardigheden te leren, meer mogelijkheden tot succesvolle toepassing van nieuw aangeleerde vaardigheden en meer bekrachtiging vanuit de omgeving dan bij mensen met zwaardere problematiek die vaak langdurige psychiatrische behandelingen achter de rug hebben. Jarenlange psychiatrische behandeling blijkt vaak tot gevolg te hebben dat het interessegebied van mensen steeds kleiner wordt en dat ook hun cognitieve en andere realiteitstoetsende functies steeds verder degenereren. Hoe verder mensen in algemeen maatschappelijk opzicht aan de kant komen te staan, hoe moeilijker het is hen te avertuigen van het nut van het uitbreiden van hun persoon$11 j k$ en interpersoonl $1 j k$ gedragsrepertoire.

De persoonlijke vaardigheidstherapieën zijn minder effectief dan de interpersoonlijke vaardigheidstherapieën. Deze beperkte effectiviteit. kan mede verklaard worden door:

a. het feit dat bij de persoonlijke vaardigheidstherapleën het aanleren van covert gedrag centraal staat. Het aanleren wan leerpunten- 
sequenties waarin de nadruk ligt op overt gedrag (=de interpersoon11 jke vaardigheidstherapieën), sluit beter aan aan de in hoofdstuk 1 beschreven leeroriëntatie van clienten uit de lagere sociaal-economische klassen dan het aanleren van leerpuntensequenties waarbij de nadruk 1 lgt op het aanleren van covert gedrag (=de persoonlijke vaardigheidstherapieën).

b. het feit dat de groepsbijeenkomsten bij de persoonlijke vaardigheidstherapieen meer een praat- dan doe-karakter hebben.

$c$. het feit dat de ten aanzien van de persoomlijke waardigheidstherapieën ontwikkelde leerpuntensequentie erg abstract en algemeen van aard zijn.

d. het feft dat de uitvoering van de persoonlijke vaardigheidstherapleên de aanwezigheid van basale interpersoonlijke vaardigheden vooronderstelt.

e. het feit dat er tijdens de persoonlijke vaardigheidstherapieën "tweesporig" gewerkt moet worden door therapeuten. Er wordt gebruik gemaakt van cognitieve herstructurering zowel als gedragsoefening. Dit vereist een grote mate van deskundigheid van de kant van de therapeuten ( vg1. Engels en Diekstra, 1986).

f. het feit dat er bij het effectiviteitsonderzoek alleen gebruik gemaakt werd van afgeleide criteria in de zin van meer algemene cognitieve factoren en dimensies en er geen gebruik gemaakt werd van directe vaardigheidstoetsen en/of andere varmen van gedragsobservatie(s) als evaluatie-instrument.

8.7. DE WIJZE WAAROP DE PERSOONLIJIKE VAARDIGHEIDSTHERAPIEEN WORDEN UITGEVOERD

Praktische ervaringen met de uitvoering van de persoonlijke vaardigheidstherapieèn leidden tot de nu volgende kanttekeningen:

$a$. het feft dat er tijdens deze vaardigheidstherapleën geen aandacht wordt besteed aan het aanleren van palliatieve copingwijzen heeft tot gevolg dat deelnemers met een in dit opzicht ontoereikend copingrepertoire niet voldoende kunnen profiteren van deelname aan persoonlijke vaardigheldstherapieën. Problematische situaties word- 
en vaak gekenmerkt door paniekreacties. Het toepassen van palliatieve copingwijzen vormt in dergelijke situaties vaak een voorwarde vooraleer instrumentele coping mogelijk wordt.

b. het toepassingsgebied van de persoonl ijke vardigheidstherapieên blijkt te breed en algemeen uitgezet. Dit heeft tot gevolg dat de door deelnemers ingebrachte thema's te sterk diwergerem zowel wat betreft aard als omvang. Het vooraf ingeschatte voordeel van deze benadering, dat de deelnemers tijdens de groepsbijeenkoms ten kunnen ervaren hoe de betreffende leerpuntensequentile op zeer verschillende inhouden kan worden toegepast (=generalisatie-training), brengt in praktijk als madeel met zich mee dat deelnemers tijdens de groepsbijeenkomsten herhaaldelijk geconfronteerd worden met situaties die voor henzelf minder herkenbaar en ook minder relevant zijn. Het daaruit voortvloeiend gebrek aan betrokkenheid befnvloedt de tijdens de groepsbijeenkomsten beoogde leerprocessen negatief. Wat de taak en functie van de persoonlijke vaardigheldstherapeuten betreft, kan het feit dat het toepassingsgebied van de persoonlijke vaardigheidstherapieën zo breed en algemeen is uitgezet, madelig zijn ondat daardoor van hen deskundigheid en inzicht verwacht wordt ten aanzien van de meest uiteenlopende probleemsituaties en klachtgebieden. Dergelijke eissen ten aanzlen van kennis- en vaardigheidsniveau van therapeuten blijken veelal niet haalbaar.

Een en ander pleit voor de toepassing van persoonlijke vaardigheidstherapieën per specifieke klachtensoort c.q. probleencategorie. Dit stelt minder hoge eisen aan de therapeuten en makt het bovendien mogelijk dat men de deelnemers doelgerichter kan trainen in relevante instrumentele en palliatieve copingwijzen. Als voorbeelden van speciffieke probleemcategorleèn zljn aan te geven: rowwproblemen, echtscheidingsproblemen, problemen ten gevolge van "het lege nest syndroom"; psychische problematiek ten gevolge van werkloosheid en arbeidsangeschiktheld; psychische problematiek ten gevolge van (voortijdige) pensionering; homogene fobische problematilek.

c. het aanleren van persoonlijke vaardigheden blijkt in grotere mate te appelleren op het reflectie- en denkvemogen van de deelnemers dan het aanleren van interpersoonlijke vaardigheden. Hoewel bij 
opzet en uitwerking van de persoonlijke vaardigheidstherapieẻn zoveel mogel ijk rekening werd gehouden met de in hoofdstuk 1 besproken leeroriëntatie van individuen afkomstig uit de lagere sociaaleconomische klassen, blijft de mogel ljkkheid bestaan dat tijdens de ultvoering daarvan een te sterk beroep wordt gedaan op het analytisch vermogen van de deelnemers ten aanzien wan eigen denkgedrag door middel van zelfreflectie. Bovenstaande kan het beloop van de tijdens persoonlijke vaardigheidstherapieën beoogde leerprocessen belemmerd hebben. Het is mogelijk dat de tijdens de persoonlijke vaardigheidstherapieën gehanteerde leermethodes onvoldoende zijn aangepast aan de typische eigen aard van de in hoofdstuk 1 beschreven leerstijl van LIBO-clienten.

d. na verloop van tijd werd duidelijk dat het merendeel van de hulpverleners, die clienten voor deelname aan persoonlijke vaardigheidstherapieën verwezen, vooralsnog onvoldoende geschoold blijkt persoonlijke vaardigheidstekorten en -excessen tijdig en adequat in te schatten. Interpersoonlijke vaardigheidstekorten en -excessen vormen voor hulpverleners vertrouwder en bekender terrein dan persoon 1 ijke vaardigheidstekorten en -excessen.

Deze ervaring pleit voor exploratie van de mogelijkheid an de betreffende hulpverleners meer inzicht te geven in de rol van cognitieve aspecten c.q. covert gedrag in relatie tot problemen en/of $k l$ achten zoals die door clienten gepresenteerd worden. Daartoe dienen ter onderkenning van in dit opzicht relevante gedragstekorten en -excessen de nodige assessment-methoden ontwikkeld te worden met behulp waarvan het totale gedragsrepertoire van een individu in beeld gebracht kan worden wat betreft persoonlijke zowei als interpersoonlijke vaardigheden. Bij de ontwikkeling van dergelijke assessment-methoden dient het onderscheid tussen instrumentele en palliatieve copingwijzen in aanmerking te worden genomen (Lazarus, $1966)$.

e. Uit ervaringen met de uitvoering van persoonlijke en interpersoon$11 j k$ ke vaardigheidstherapieën blijkt bovendien dat de wijzen waarop elk van beide worden gerealiseerd, gevolgen heeft voor het beloop van de daarmee beoogde leerprocessen. De tot nu toe opgedane ervaringen met de uitvoering van elk van belde leidt tot de conclusie 
dat het spelelement zoals dat geoperationaliseerd wordt bij het aanleren van interpersoonlijke wardigheden, het beloop wan de beoogde leerprocessen bij LIBO-clienten positief beinvloedt. Tijdens de interpersoonlijke vaardigheidstherapieèn wordt er relatief weinig gepraat over en wooral, in (rollen) spelvorm, geoefend met de betreffende leerpuntensequentie. De bijeenkomsten worden zodaende gekenmerkt door een grote mate van activiteit en een hoog werktempo. Bij de persoonlijke vaardigheidstherapieën wordt er in verhouding veel meer gepraat over de betreffende leerpuntensequentie en hebben de gedragsoefeningen veel minder een doe- en activiteltskarakter: er wordt veel meer geprat óver. Tijdens de persoonlijke vaardigheidstherapieën wordt nauwelijks gebruik gemaakt van oefeningen in (rollen) spelvorm met inschakeling van medegroepsleden als antagonisten. Een en ander heeft een geringer activiteitsniveau van de deelnemers tijdens de bijeenkomsten tot gevolg. Deze bijeenkonsten krijgen zodoende een meer statisch karakter waardoor de betrokkenheid van de deelnemers bij het leepproces minder wordt.

f. de uiltvoeringsfase die bij elk van de vier persoonlijke vaardigheidstherapieën een rol speelt, vooronderstelt de aanwezighelid van basale interpersoonlijke vaardigheden in het gedragsrepertoire van de deelnemers. Tijdens de uiltvoering van de persoonlijke vaardighelidstherapieën bieek een groot aantal deelnemers niet over de noodzakelijke interpersoonlijke vaardigheden te beschikken om de uitvoeringsfase van de persoonlijke vaardigheden te kumnen realiseren. Dit gegeven impliceert een belangrijjke beperking van de mogelijke effectiviteit wan deelname aan persoonlijke vaardigheidstherapieën. Het niet ter beschikking hebben van voldoende interpersoonlijke vaardigheden heeft tot gevolg dat men niet in staat is de uitvoeringsfase van de persoonlijke vaardigheden in praktijk te brengen. Men kan dan geen positieve ervaringen opdoen met de uitvoering van de nieuw aangeleerde persoonlijjke vaardigheden en blijft daardoor gevangen zitten in een spiraal van negatieve persoonlijke competentie-verwachtingen. 
D.t proefschrift beschrijft de ontwikkeling en evaluatie van een serie persoonlijke vaardigheidstherapieẻn voor kansame geestelijke gezondheldszorg clienten.

Hoofdstuk een geeft een overzicht van recente ontwikkelingen in de psychotherapeutische hulpverlening aan clienten uit de lagere socialeconomische klassen. Na een beschrijving van de in relatie tot deze clientgroep gehanteerde psychotherapiemethodieken, worden vervolgens de redenen weergegeven waarom de Mastrichtse Goldsteinprojectgroep koos voor aanpassing van de "Structured Learning Therapy" van Arnold Goldstein. Vorm en inhoud van deze methode worden uitvoerig beschreven. Het betreft een structurerende, kortdurende, directieve psychotherapie-methode, gebaseerd op modeling, gedragsoefening, bekrachtiging en transfertraining.

De methode is gericht op het aanieren van vaardigheden en ulibreiding van het gedragsrepertoire. De ontwikkelde vaardigheidstherapieën hebben betrekking op het aanleren wan persoonlijke en interpersoonlijke vaardigheden. Dit proefschrift betreft ontwikkeling en evaluatie van een serie persoonlijke vaardigheidstherapieën voor kansarme geestelijke gezondheidszorg clienten.

Hoofdstuk twee betreft de wijze warop de inhoud van de persoonlijke vardigheidstherapieën werd vastgesteld. Deze inhoud werd bepaald op basis van literatuur-onderzoek, waarbij het werk van A. Goldstein als ultgangspunt diende. De door de Goldsteinprojectgroep ontwikkeide persoonlijke vaardlgheidstherapieën "dagelijkse problemen aanpakken"; "besilssingen nemen"; "Informatie verzamelen" en "veranderingen aanpakken" worden elk afzonderlijk beschreven.

Hoofdstuk drie beschrijft de wijze warop de persoonlijke vaardigheidstherapieén worden uitgevoerd. Deelname aan deze vaardigheidstherapleän vormt een aanvulling op c.q. ondersteuning van meer uitgebreide individuele behandelingsprogramma's. 
Elke therapie is gericht op het aanleren van éen bepalde vaardigheid, geoperationaliseerd met behulp van een voorgestructureerde leerpuntensequentie. Bij de persoonlijke vaardigheidstherapleën ligt de nadruk op het aanleren van covert gedrag c.q. "denkstappen". In een vast aantal wekelijkse groepsbijeenkomsten wan elk twee uur, onder begeleiding van 2 therapeuten, wordt de leerpumtensequentie ingeoefend met behulp van gedragsoefening, feedback, modeling, (sociale) bekrachtiging, didactische instructie en transfer-training. De wijzen waarop deze leerprincipes worden geoperationaliseerd tijdens de groepsbijeenkomsten, worden uitputtend beschreven. De indicaties voor deelname aan persoonlijke vaardigheidstherapieën worden besproken. Dok worden een aantal algemene richtlijnen voor vaardigheidstherapeuten weergegeven.

Hoofdstuk vier beschrijft de opkomst van de cognitieve gedragstherapie. Er wordt aandacht besteed aan recente ontwikkelingen op dit terrein. De cognitieve gedragstheraple wordt ingedeeld in drie categorieen: cognitieve herstructurering, coping-ski11s-therapieën en problemsolving-therapieën. Ook worden de redenen weergegeven waarom de persoonlijke vaardigheidstherapieën a 1 a Goldstein als een vorm van problem-solving-therapie kunnen worden opgevat. Tot slot worden een aantal kanttekeningen geplaatst bij de momenteel in de gedragstherapie te constateren trend in cognitieve richting.

In hoofdstuk vijf worden recente ontwikkelingen beschreven in de opvattingen ten aanzien van de wijze waarop leerprocessen verlopen. Deze ontwikkelingen betreffen de herontdekking van de rol van cognitieve factoren bij het tot stand komen van gedrag(sverandering). Nagegaan wordt wat de consequenties van deze ontwikkelingen zijn voor vaardighefdstherapieën. De theorieën van Rotter, Bandura en Lazarus worden uitgebreid beschreven. Persoonlijke competentie-verwachtingen, respons-uitkomst-verwachtingen en appraisal-processen blijken een belangrijke rol te spelen bif het aanleren van persoonlijke zowel als interpersoanlijke vaardigheden. Ook wordt een poging gedaan de door Rotter, Bandura en Lazarus ontwikkelde modellen aan elkaar te relateren. Tot slot wordt beschreven wat de relevantie is van dit geinterpreteerd cognitief sociaal-1eertheoretisch model voor de wijze waarop persoonlijke en interpersoonlijke vaardigheidstherapieën worden uitgevoerd. 
In hoofdstuk zes wordt de constructie en validering beschreven van een zelfontworpen meetinstrument ter evaluatie van de effecten van persoonlifike vaardigheidstherapleën. Gekozen werd voor de ontwikkeling van een meetinstrument in de vorm van een schriftelijke vragenlijst. Er worden geen directe vaardigheidstoetsen en/of andersoortige vormen van gedragsobservatie als effectiviteitscriteria gehanteerd. Bij factor-analytisch onderzoek bleek de geconstrueerde vragenlijst "Doelmatig Handelen" uit 3 subschalen opgebouwd. Analyse van de inhoud van de betreffende ttems leidde ertoe de gevonden subschalen als volgt te benoemen:

a. vertrouwen in elgen probleemoplossingsvaardigheid $\left(\mathrm{DH}_{1}\right)$

b. plannen en voorultenken $\left(\mathrm{DH}_{2}\right)$

c. consequent handelen $\left(\mathrm{DH}_{3}\right)$.

Voor elk van deze subschalen werd de coëfficient voor interne consistentie (Cronbach's alpha) bepaald en de test-hertest betrouwbarheid vastgesteld. De in dit opzicht gevonden waarden varieerden van 0.61 tot 0.82 . DH-subschaal 1 vormt de in dit opzicht sterkste schaal, DHsubschaal 3 de zwakste. Ook werd nagegaan in hoeverre de variabelen leeftijd, geslacht en opleidingsniveau van invloed waren op de scores op de 3 DH-subschalen. De variabele leeftijd bleek geen significante invloed te hebben op de totaalscores per subschaal, de variabelen geslacht en opleidingsniveau we1.

Bij de bepaling van de divergerende validiteit van de 3 subschalen bleek dat $\mathrm{DH}_{2}$ ook aspecten van copingstijlen, neuraticisme en beheersingsoriëntatie meet. $\mathrm{DH}_{3}$ blijkt bovendien aspecten van zelfwaardering te meten en $\mathrm{DH}_{1}$ aspecten van zelfwaardering en van rigiditelt. De hoogte van de gevonden correlaties is echter niet zodanig dat er geen sprake meer is van operationalisatie van eigenstandige aspecten wan persoonlijke (on)vaardigheid. Wat deze aspecten in concreto inhouden, blijfft vooralsnog onduidelijk.

In hoofdstuk zeven wordt de vraag naar de effectiviteit van de persoonl ijke vaardigheidstherapieën aan de orde gesteld.

$B i j$ deelnemers aan persoonlijke vaardigheidstherapieën werden metïngen verricht een week vooraf aan en een week na afloop van deelname. Dezelfde metingen vonden op vergelijkbare tijdstippen ook plaats bij 
mensen die op de wachtlijst stonden voor deelname aan persoonlijke vaardigheidstherapieën. Deze zgn. Wachtiljst-clienten houden tijdens de wachtperiode normal contact met hun hoofdbehandelaar c.q. verwijzer. Bij de experimentele groep werd een 2 e nameting verricht een jaar na beëindiging van deel hame aan persoonlijke vaardigheidstherapieen.

Als effectiviteitscriteria hanteerde men de in hoofdstuk 6 beschreven vragenlijst Doelmatig Handelen, de IE-schal, de SE-schaal, de RGschal en subschal 1 en 3 uit de Utrechtse Coping Lijst. De gegevens werden verzameld bij kansarme clienten in behandeling bij een ambulante danwel klinische instelling voor geestelijke gezondheidszorg. De experimentele groep kan in de volgende subgroepen worden onderverdeeld:

1. LIBO-clienten met overwegend milde, psychosociale problematiek (AGGZ-groep; $N=17$ )

2. LIBO-c) ienten met (sociaal-)psychiatrische problematiek (SPD-groep: $N=14)$

3. LIBO-clientem met psychiatrisch bepaalde WAO-problematilek (WAOgroep; $\mathrm{N}=10$ )

4. LIBO-clienten opgenomen op de afdeling $k l$ inische gedragstheraple van een psychiatrisch ziekenhuís (AKG-groep; $N=11$ ).

Voor de totale experimentele groep $(N=52)$ geldt dat men significante verschillen tussen woor- en nameting kan constateren ten aanzien van $\mathrm{DH}_{1}, \mathrm{DH}_{3}$, IE en SE. Ten aanzien van subgroep 1 - de subgroep met overwegend milde, psychosocialle problematiek - geldt dat er eveneens sprake is van significante verschillen tussen voor- en nameting ten aanzien van $\mathrm{DH}_{1}, \mathrm{DH}_{3}$, IE en $\mathrm{SE}$.

Ten aanzien van de overige 3 subgroepen, met zwaardere problematiek van meer psychiatrische aard, bleken geen significante verschlllen tussen voor- en mameting aantoonbaar.

Voor de controlegroep geldt dat men alleen significante verschillen tussen voor - en nameting kan constateren ten aanzien van $U C L_{1}$. Bij afloop van de controleperiode blijken de proefpersonen significant minder gebruik te maken van de copingstijl "aanpakken" als reactie op problemen dan bij de voometing.

Experimentele en controlegroep verschillen op geen enkel criterium significant van elkaar op de voometing. 
Wat de experimentele groep betreft, is sprake van een herhaalde nameting een jaar na deelname aan persoonlijke waardigheidstherapieën. Bij deze herhaalde nameting blijkt dat de tijdens deelname aan persoon1 ljke vaardigheidstherapleën bereikte resultaten stabiel blijven tijdens de follow-up periode. Ten aanzien van $\mathrm{DH}_{2}$ en $U \mathrm{UCL}_{1}$ kan men tijjens deze periode significante vooruitgangen constateren die niet aantoonbaar waren bij nameting 1 .

Concluderend kan men dus stellen dat persoonlijke vaardigheidstherapleën enigszins effectief $b \mathbb{I j j k e n} b i j$ LIBO-clienten met overwegend milde, psychosociale problematiek. Bij LIBO-clienten met zwaardere problematiek van meer psychiatrische aard blijkt geen enkel significant effect aantoonbaar.

In hoofdstuk acht komen de belangrijkste thema's uit dit proefschrift nogmaals aan de orde en worden van kritische kanttekeningen voorzien. Wat de psychotherapeutische hulpverlening aan clienten uit de lagere sociaal-economische klassen betreft, is de conclusie gerechtvaardigd dat naast methodielkvariabelen ook houdings- en verwachtingsaspecten een rol spelen. Sociaal-economische factoren bepalen in welk behandelingskanaal een client terecht komt en niet de aard en omvang van de bij hen aanwezige psychische, psychosociale en/of psychosomatische probllematiek. De ruime aandacht die men in de zeventiger jaren kan constateren voor het psychotherapeutisch werk met clienten uit de lagere klassen, blijkt in de jaren tachtig enigszins gekenterd.

Vervolgens wordt aandacht besteed aan de relatie tussen persoonlijke en interpersoon1ijke vaardigheidstherapieën. Geconstateerd wordt dat beide niet geheel los staan van elkaar maar elkaar onderling aanvul$1 \mathrm{en}$.

Ten aanzien van de cognitieve ontwikkelingen in de gedragstherapie concludeert men dat vooralsnog onduidelijk is wat de relatieve bijdrage is van cognitieve versus gedragsgerichte technieken in het therapeutisch veranderingsproces. Een louter cognitivistische benadering in deze is even beperkt en eenzijdig als een louter behavioristische benadering.

Ten aanzien van het in hoofdstuk vijf geschetst geintegreerd cognitief sociaal-leertheoretisch model, $k$ an men concluderen dat dit model de 
interactie persoon-situatie zodanig weergeeft dat verwachtingsconcepten en andere cognitieve beoordelingsprocessen aan elkar gerelateerd kunnen worden. Dit model dient in de toekomst nader empirisch getoetst te worden.

De recente ontwikkelingen ten aanzien van het concept "coping" worden samengevat. Geconcludeerd wordt dat dit concept een steeds belangrijker plaats gaat innemen in de psychologische theorie-worming en ook ten aanzien van de psychotherapeutische praktijk. Er is dringend behoefte aan de ontwikkeling van een assessment-methode met behulp waarvan men het copingrepertoire van een individu in kaart kan brengen: palliatief zowel als instrumenteel, zowel wat betreft kwaliteit, als ook wat betreft kwantiteit en flexibiliteit.

Wat het uitgevoerde effectiviteitsonderzoek betreft, kan men concluderen dat persoonlijke vaardigheidstherapieën enig effect sorteren bij kansarme clienten in de ambulante geestelijke gezondheidszorg met overwegend milde, psychosociale problematiek. Bij clienten met zwaardere problematiek, van meer psychiatrische aard, blijken geen significante resultaten aantoonbaar. Besproken wordt hoe men deze beperk te effectiviteit kan verklaren. Het hoofdstuk eindigt met een aantal kanttekeningen bij de wijze waarop de persoonlijke vaardigheidstherapieën wordlen uitgevoerd. 
This dissertation describes the development of a psychotherapy method made to teach lower class clients "personal" skills as well as some research into the effectiveness of these so called personal skill therapies. Attention is paid to the place of these personal skill therapies in the general field of cognitive behavior therapy.

Chapter one reviews recent developments in the practice of psychotherapy with lower class clients. Current methods are described and also the reasons why the Goldsteinproject in Maastricht chose to adapt the Structured Learning Therapy designed by Arnold Goldstein to the psychological needs and possibilities of lower-income people in the Netherlands. Shape and content of this method are fully described. The procedure is structured, brief and directive and based on mode1ing, behaviour-rehearsa1, reinforcement and transfer-training. It aims at the acquisition of skills and the extension of behavioural patterns. These skill therapies aim at the acquisition of personal and interpersonal skills. This dissertation concerns development and evaluation of the personal skill therapies.

Chapter two describes the way the personal ski11 therapies were composed. The content of the personal skill therapies was established by means of a search of the relevant literature. The previous work done by Arnold Goldstein served as the starting point for this search. The personal skill therapies as developed by the Goldsteinproject Maastricht are discussed separately. These personal skill therapies are labelled 'daily problem solving', 'decision-making', 'information gathering' and 'effecting changes. .

Chapter three describes the personal skill therapy program in its ultimate design. The personal skill therapies are meant to be part of a more encompassing treatment program designed by an individual therapist. Each therapy program aims at the acquisition of a single personal ski11. Each skill is divided into a fixed set of preprogrammed bits of behaviour. These are the so-called learning points. These learning 
points serwe for guidance in the performance of the personal skill concerned. During the personal skill therapies emphasis is laid on the acquisition of covert behaviour. Each therapy program consists of a predetermined number of groupsessions on a fixed day of the week. Each session is to be led by two therapists and takes two hours. The method is based on the behavioural principles of behavioural rehearsal, feedback, modeling, (social) reinforcenent, instruction and transfertraining. The indications for participation in this category of skill therapies are described as well as some general guidelines for Goldstein therapists.

The fourth chapter deals with the rise of cognitive behavior therapy. Recent developments are described. Cogmitive behavior therapy is divided into three categories: cognitive restructuring, coping-skill therapies and problem solving therapies. The growing tendency 'to go cognitive" will be discussed critically. Finally the reasons are discussed why personal skill theraples are to be considered as a kind of problem solving therapy.

The fifth chapter describes recent developments in the opinions cancerning the way learning processes take place. These developments relate mainly to the rediscovery of the role played by cognitive factors in explaining behaviour and behaviour-modification. The consequences of these developments for skill therapies are discussed. The cognitive social-iearning theomies developed by Rotter, Bandura and Lazarus are reviewed extensively. Expectations of personal efficacy, respons-outcome-expectations and appraisal-processes are of crucial significance in the acquisition of personal and interpersonal ski11s. The chapter also contains the description of an integrated cognitive social-learning model that integrates the concepts developed by Rotter, Bandura and Lazarus. The chapter finishes with a description of the relevancy of this integrated model for the way the personal skf11 therapies are put into practice.

Chapter six reports the development of a measurement-device meant to facilitate efficient investigation of the effects achieved by the personal skill therapies for lower class clients. The chapter also 
contains a report of an investigation into the validity of this instrument. The instrument takes the form of a (witten) questionnaire and is labelled the questionnaire "goal-directed performance" in Dutch abreviated as DH-questionnaire. The criteria for effectivity did not take the shape of direct sikill tests or any other form of behavioural observation.

A factor-analytic study of the DH-questionnaire yielded 3 main factors. Content analysis of the relevant items revealed that these 3 factors could be labelled as:

1. confidence in one"s own personal problem solving ability

2. planning and thinking in advance

3. taking consequent action.

Internal consistency as well as test-retest reliabilities varied between 0.63 and 0.82 . Subscale 1 forms the in this respect strongest scale, subscale 3 the weakest. Al so investigated was whether the variables age, sex and education influenced the scores on the 3 subscalles. Education did not significantly influence the scores on the subscalles, the variables sex and age did.

Research into the diverglent validity of the 3 subscales led to the conclusion that subsicale 2 also measures certain aspects of copingstyles, neuroticism and locus of control. Subscale 3 additionally measures certain aspects of self-esteem and subscale 1 certain aspects of self-esteem and rigidity. The magnitude of the correlations found is not as such that it can be concluded that the three subscales do not measure specific aspects of personal skilli. What these aspects are remains unclear.

In chapter seven some research is presented into the effectiveness of the personal skill therapies.

Particlpants of cognitive skill therapies were subjected to data-collection-interviews one week in advance of and one week after termination of participation in personal skill therapies. The same data were collected at comparable points in time by clients waiting for participation in personal skill therapies, who cantinued their regular appointments with their individual therapists. As far as the experimental condition is concerned follow-up data were callected one year after termination of participating in personal skill therapies. 
As outcome-criteria were selected the in chapter 6 described questionnaire 'goal-directed performance', the internal-external locus of control questionnaire, the self-esteem questionnaire, the rigidity questionnaire and the subscales 1 and 3 of the 'Utrecht coping Questionnaire'. Data were collected with clients treated at institutions for mental health service: one clinic and three community centres. The experimental condition is divided into the following subgroups:

1. lower-class clients with predominantly mild, psychosocial problems (AGGZ-group; $N=17$ );

2. lower-class clients with predominantly (social-) psychiatric prob1 ems (SPD-group; $N=14$ );

3. lower-class clients who have been rejected for work because of psychiatric problems (WAO-group; $N=10$ );

4. 1ower-class clients in treatment at a psychiatric-hospltal-unit for clinical behaviour therapy (AKG-group; $N=11$ )).

For the experimental condition in total $(N=52)$ significant differences between pre- and post-measures were found with regard to $\mathrm{DH}_{1}, \mathrm{DH}_{3}$, IE and SE. As far as subgroup 1, the group with mild psychosocial prob1 ems, is concerned the same differences were found. The three other subgroups, with more severe problems, more psychiatric by nature, showed no significant differences between pre- and post-measures.

As far as the waiting-list-control-condition is concerned significant differences between pre- and post-measurement could only be detected on behalf of $U C L_{1}$. On post-measurement the clients of the waiting1 ist-control-condition appear to use the coping style "tackling the problem" significantly less than on the pre-measurement.

Experimental condition and waiting-list-control-condition did not differ significantly on the pre-measures.

As far as the experimental condition is concerned a second post-measurement was organized one year after participation in personal skill therapies. This second post-measurement showed that the results of the personal skill therapies have been maintained during the follow-up period. On $\mathrm{DH}_{2}$ and $U \mathrm{UL}_{1}$ significant improvements are shown which did not exist at the time of post-measurement 1.

The conclusion can be drawn that personal $5 \mathrm{kill}$ therapies are slightly effective in working with lower class cllients with predominantly mild, 
psychosocial problems. As far as lower-class cllients with more severe problems, more psychiatric by nature are concerned no significant results were found.

In chapter 8 the main topics of this dissertation are reviewed and critically discussed.

As far as psychotherapy for lower class clients is concerned the conclusion seems justified that treatment problems are determined by methodological variables, attitude-factors, and expectancy variables. Socio-economical variables decide in which treatment-setting a client will be treated instead of content and intensity of the existing psychic, psycho-social and/or psychosomatic problem. The broad attention for psychotherapy with lower class clients of the seventies turned slightly down in the eighties.

Attention is paid to the interrelationships between personal skill therapies and interpersonal skill therapies. The conclusion is reached that both kinds of skill-therapies supplement each other.

As far as the cognitive trend in behaviour therapy is concerned the conclusion is drawn that at this moment there is no exact evidence of the way in which cognitive factors, physiological aspects, emotions and behaviour are interrelated. This conclusion has consequences for the psychotherapeutic practice to that effect that treatment-programs should consider all these different aspects of human behaviour. A purely cognitivistic approach seems as 1 imited and one-sided as a purely behaviouristic approach.

As far as the in chapter five presented cognitive paradigm based on soctal learning theory is concerned, the conclusion can be drawn that this paradigm represents the interaction person-situation in such a way that expectational-concepts and other cognitive labelling-processes are integrated. This paradigm needs further empirical exploration.

Recent developments with regard to the coping-concept are summarized. This concept seems to be taking first place in general psychological theory as well as psychotherapeutic practice. There seems to be a growing need for the development of a method for assessing the coping abilities and skills of an individual person: palliative as well as instrumental, as far as quality is concerned as well as intensity and flexibility. 
As far as the research into the effectiveness of the personal skill therapies is concerned it appeared that these theraples are most effective with lower class clients of ambulatory mental health institutions: clients with predominantly mild psychosocial problems.

As far as lower class clients with more severe problems are concerned no significant results are found. Attention is paid to the ways these results can be interpreted. The chapter ends with some critical remarks on the way the personal skill therapies are put into practice. 
ABRAMOWITZ C.V., Abramowitz S.I., Roback H.H., Jackson C. Differential effective grouptherapies as a function of client internal-external control. Journal of Consulting and Clinical Psychology, 1972, 42, 849-853.

ADKINS W.R. Live skills: structured counseling for the disadvantaged. Personell and Guidance Journa1, 1970, 49, 108-116.

ALLEN G., Chinsky J., Larcen S., Lochmam J.E., Selinger H. Community psychology and the schools. Wiley and Sons, Toronto, 1976.

ANDERSON J.R., Bower G.H. Human associative memory. Washington DC Winston, 1973.

ANDRIESSEN J.H.T.H. Interne of externe beheersing. Nederlands Tijdschrift voor de Psychologie. 1972, 27, 173-198.

ANDRIESSEN J.H.T.H., Cadsand van J.P. Een analyse van de Nederlandse I-E schaal. Nederlands Tijdschrift voor de Psychologie, 1983, 38, 7-24.

APPELS A. Voorlopige handlefiding bij de Delftse Vragenlijst. Swets en Zeitlinger BV, Amsterdam, 1974.

APPELS A. Over de geestelijke gezondheid van de Delftse studenten. Universiteit en Hogeschool, 1975, jaargang 22, 2, 87-92.

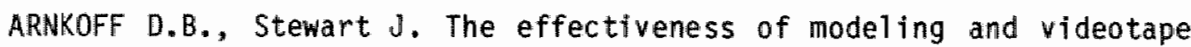
feedback on personal problem-solving. Behavior Research and Therapy, $1975,13,127-133$.

ARONSON H., Overall B. Treatment expectations of patients in two social classes. Social Work, 1966, 11, 35-41.

ARRINDELL D.W., Damsma S.A., Ettena, H. De score op de Delftse Vragenlijst (DV) als neuroticisme-index in epidemiologisch onderzoek. Tijdschrift Sociale Geneeskunde, 1980, 58, 599-602.

AULD F., Myers J.K. Contributions to a theory for selecting psychotherapy patients. Journal of C1inical Psychotherapy, 1954, 10, $56-60$.

AVERILL J. Personal control over aversion stimuli and its relationship to stress. Psychological Bulletin, 1973, 88, 286. 
BAEKELAND A., Lundwa11 G. Dropping out of treatment: a critical review. Psychological Bulletin, 1975, 82, 738-783.

BAILEY M.A., Warshaw L., Eichler R.M. A study of factors related to length of stay in psychotherapy. Journal of Clinical Psychology, $1959,15,442-444$.

BAKKER-DE PREE B.J. Vrije Differentiatie: een nieuwe gedragstherapeutische methode. Gedragstherapie, 1983, 16, 255-269.

BANDURA A. Principles of behavior modification. New York, Holt, Rinehart, Winston, 1969.

BANDURA A. Behavior theory and the models of man. American Psychologist, $1974,29,859-869$.

BANDURA A. Self-efficacy: Towards a unifying theory of behavioral change. Psychological Review, 1977, 84, 191-215.

BANDURA A. Reflections on self-efficacy. In: C.M. Franks, G.T. Wilson. Annual Review of Behavior Therapy, Theory and Practice. New York, Brunner Maze1, 1979.

BANDURA A. Recycling mi sconceptions of perceived self-efficacy. Cognitive therapy and research, 1984, 8, 231-255.

BECK A.T. Thinking and depression 2: theory and therapy. Archives of general psychiatry, 1964, 10, 561-571.

BECK A.T. Depression: clinical, experimental and theoretical aspects. New York, Harper and Row, 1967.

BECK A.T. Cognitive therapy: nature and relation to behavior therapy. Behavior Therapy, 1970, 1, 184-200.

BECK A.T. Cognitive therapy and the emotional disorders. New York, International University Press, 1976.

BECK A.T., Rush A.J. Shaw B.F., Emery G. Cognitive therapy of depression. New York, J. Wiley and Sons, 1979.

BECKERS B. Psychotherapie met arbeidersclienten, theorie en praxis. Doct. scriptie klinische psychologie, KU Nijmegen, 1978.

BECKERS B., Beekers M. Vaardigheden voor doelmatig handelen. Tijdschrift K1 inische Psychologie, 1982, 12e jaargang, 4, dec. 28-51.

BEDELL J.R., Archer R.P., Marlowe Jr. H.A. A description and evaluation of a problem solving skills training program. In: D. Upper, S.M. Ross (eds.): Behavioral group therapy, an annual review. Champaign, 111. Research Press, 1980. 
BEEKERS M. Videomodellen in vaardigheidstherapieen. De Psycholoog, $1980,11,629-636$.

BEEKERS M., Beckers B., Bongaarts J., Peters J. Psychotherapeutische hulpverlening aan cliënten uit de lagere sociali-economische klassen: een keuze voor Goldstein. Tijjdschrift voor Psychotherapie, $1980,6,87-98$.

BEEKERS M. Gooijen J. Spel met grenzen: een Goldsteintherapie. Tijdschrift voor Psychotherapie, 1980, 6, 326-337.

BEEKERS $M_{*}$, Halfens $R$. Met het oog op vaardigheidstherapiën: cliënten over hun interpersoonl ijk gedrag. Tijdschrift voor Psychotherapie, $1981,6,318-327$.

BEEKERS M. Interpersoonlijke vaardigheidstherapieën voor kansarmen. Swets en Zeitlinger, Lisse, 1982.

BEEKERS M., Beckers B. "Goldsteintherapieën': Vaardigheidstherapieën op maat. Groep en systeem, Redactie G. Schwencke, Bergen op Zoom, $1984,91-105$.

BELLACK A.S., Hersen M., Turner S.M. Role-playing tests for assessing social ski11s: Are they valid? Behavior Therapy, 1978, 9, 448-461.

BELLACK A.S., Hersen M., Lamparski D. Role-playing tests for assessing social skf11s: Are they valid? Are they useful? Journal of Consulting and Clinical Psychology, 1979, 47, 335-342.

BENNIS, W.G., Benne K.D., Chin R. The planning of change. 2nd edition, New York, Holt, Rinehart, Winston, 1973.

BERGLAND B.W., Quatrano L.A., Lundquitst G.W. Group social models and structured interaction in decision-making. The Vocational Guidance Quarterly, 1975, 29-36, september.

BIRK J.M. Experience-bases career exploration with high school women. In: Krumboltz J.D., Thoresen C.E. (eds): Counseling Methods. New York, Holt, Rinehart, Winston, 1976.

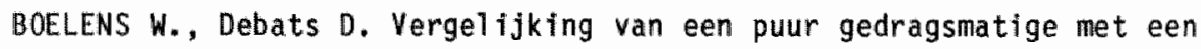
puur cognitieve behandeling voor depressieve patiënten. In: Beer R., Mulder H. (red.): Psychologische benaderingswijzen van depressie. Lisse, Swets en Zeitlinger, 1983.

BOURNE L.E. Jr., Ekstrand B.R., Dominovski R.L. The psychology of thinking. Englewood Cliffs, New Jersey, Prentice Hall, 1971. 
BRAGER H. New concepts and patterns for service: the mobilization for youth program. In: Riessman F., Cohen J. "Pearl A. (eds): Mental health of the poor. New York Free Press, 1964.

BRANNINGAN S.C., Rosenberg L.E., Loprete L.J. Internal-external expectancy, maladjustment and psychotherapeutic intervention. Journal of Personality Assessment, 1977, 41, 71-78.

BREMER J.J.C.B. Stress als uitdaging of bedreiging. In: E.U. Boer, F. Verhage, Ch. J. de Wolff (red.): Stress..uitdaging en bedreiging. Lisse, Swets en Zeitlinger, 1983.

BRIGHT P.D., Robin A.L. Ameliorating parent-adolescent conflict with problem-solving communication training. Journal of Behavior Therapy and Experimental Psychiatry, 1981, 12, 275-280.

BRIM 0.G., Glass P.C., Cavin D.E., Goodman N. Personality and decision processes. Stanfort, Stanfort University Press, 1962.

BURGER A.W. Cognities als 0-factor in het SORKC-schema: een slechte basis voor therapieën. Gedragstherapie, 1982, 15, 50-54.

BUTLER L., Meichenbaum D. The assessment of interpersonal problemsolving skills. In: Butler L., Meichenbaum D. (eds.): Assessmentstrategies for cognitive-behavioral interventions. New York, Academic Press, 1981.

CAUTELA J.R. Covert conditioning. In: A. Jacobs en L. B. Sachs (eds.):

The psychology of private events: perspectives on covert respons systems. New York, Academic Press, 1971.

COCHE E., Douglas A.A. Therapeutic effects of problem-solving training and play-reading groups. Journal of Clinical Psychology, 1977, 33, $820-827$.

COCHE E., Flick A. Problem-solving training groups for hospitalized psychiatric patients. Journal of Psychology, 1975, 91, 19-29.

COLE N.J., Branch C.H., Allison R.B. Some relationships between social class and the practice of dynamic psychotherapy. American Journal of Psychiatry, 1962, 118, 1004-1012.

COWEN E.L. Social and community interventions. In: P. Mussen, M. Rosenzweig (eds): Annual Review of Psychology, 1973, 24, 423-472. CRAIGHEAD W.E., Kazdin A.E., Mahoney M.J. Behavior modification: principles, issues and applications. Boston, Houghton Mifflin, 1976. 
DAYIS G.A. Current status of research and theory in human problemsolving. Psychological Bulletin, 1966, 66, 36-54.

DAVIS G.A. Psychology of problem-solving. New York, Basic Books Inc., 1973.

DAVIS G.A., Train A.J., Manske M.E. Trial and error versus 'insightfull" problem solving: effects of distraction, additional respons. alternatives and longer respons chains. Journal of Experimental Psychology, 1968, 76, 337-340.

DIEKSTRA R. Rationeel emotieve educatie. In: Diekstra R., Dassen M.: Inleiding tot de rationele theraple. Lisse, Swets en Zeitlinger, 1979.

DOHRENWEND B.P., Dohrenwend B.S. Social status and psychological dilsorder: a causal inquiry. New York, Wiley, 1969.

DRUMM D.J., Knott J.E. Structured groups for facilitating development: acquiring life skills; resolving life themes and making life transitions. Vo1. 1., New Areas in counseling series, New York, Human Science Press, 1977.

DULANY D.E. Awareness, rulles and propositional control: a confrontation with S-R behavior theory. In: T.R. Dixon, D.L. Horton (eds): Verbal behavior and general behavior theory. Englewood cilffs, New Jersey, Prentice Ha11, 1968.

DUNCAN C.P. Effects of instructions and information on problem solving. Journal of Experimental Psychology, 1963, 65, 321-327.

D'ZURILLA M.R., Goldfried M.R. Problem solving and behavior modification. Journal of Abnormal Psychology, 1971, 78, 107-126.

EASTMAN C., Marzillier J.S. Theoretical and methodological difficulties in Bandura's self-efficacy theory. Cognitive Therapy and Research, 1984, 8, 213-229.

EDELSTEIN B.A., Couture E., Cray M., Dickens P., Lusebrink N. Group training of problem solving with psychiatric patients. In: $D$. Upper, S.M. Ross (eds) Behavioral group therapy: an annual review. Champaign, 111. Research Press, 1980.

EELEN P. Cognities als 0 of R? Gedragstherapie, 15, 1982a, 52-55.

EELEN P., Bergh van den 0 . Cognitieve gedragstherapie: een hybride. Tijdschrift K1 inische Psychologie, 12, 1982b, 4, 4-28. 
ELLIS A. Reason and emotion in psychotherapy. New York, Student Press, 1962.

ELLIS A. The essence of rational therapy: a comprehensive approach to treatment. New York, Institute for Rational Living, 1970.

EMMELKAMP P.J. Behavioral treatment of agoraphobia. Dissertatie RU Utrecht, 1975.

ENGELS G.I., Diekstra R.W.F. Effectivity of rational-emotive therapy: a meta-anallysis of outcome studies accepted for publication. Journal of Clinical and Consulting Psychology, 1986.

EVANS J.R., Cody J.J. Transfer to similar and dissimilar situations. Journal of Counseling Psychotherapy, 1969, 16, 427-432.

FELDHUSEN J.F., Guthrie V.A. Models of problem solving processes and abilities. Journal of Research and Development in Education. 1979, $12,22-32$.

FELDHUSEN J.F., Houtz J.C., Ringenbach S. The Purdue Elementary Problem Solving Inventory. Psychological Reports, 1972, 31, 891-901. FERGUSON $\mathrm{J}$. Carreer guidance in the comnunity college. In: Krumboltz J.D., Thoresen C.E. (eds.): Counseling Methods, New York, Holt, Rinehart, Winston, 1976.

FISKE D.W., Hunt H.F., Lubarsky L., Orne M.T., Parloff M.R., Reiser M.F., Hussan Tuma A. Planning of research on the effectiveness of psychotherapy. Archives of General Psychiatry, 1970, 22, 22-32.

FRANK J., Gliedman L., Imber S., Nash E. Jr., Stone A. Why patients leave treatment. Archives Neurological Psychiatry, 1957, 77, 283. GAGNE R.M. The conditions of learning. 3rd ed. New York, Holt, Rinehart, Winston, 1977.

GELATT H.B. Decision-making: a conceptual frame of reference for counseling. Journal of Counseling Psychology, 1962, vol. 9, 3, 240-245.

GERSHAW M. "Biller H.B. The other helpers. New York, Lexington Books, 1977.

GILLESPIE J. Psychological education: a high school minicourse in utilizing peer counseling to teach helping and problem-solving skills and decrease feelings of alienation. Dissertation Abstracts Internationa 1, 1977, 37, 12-A pt 1, 7636. 
GLASS C.R., Levy L.H. Percelved psychophysiological control: the effects of power versus powerlessness. Cognitive Therapy and Research, 1982, 6, 91-103.

GLEISS, Seidel, Abholz. Soziale Psychiatrie: zur Ungleichheit in der psychiatrischen Versorgung. Franikurt. a/d Main, Fischer Veriag, 1973.

GOLDFRIED M.R. Systematic desensitization as training in selfcontrol. Journal of Consulting and $\mathrm{Cl} i n i c a 1$ Psychology, 1971, 37, 228-234. GOLDFRIED M.R. Psychotherapy as coping skills training. In: Mahoney, M.J. (ed.): Psychotherapy process. New York, Plenum Press, 1980. GOLOFRIED M.R., Davison G.C. Clinical behavior therapy. New York, Ho1 t, Rinehart, Winston, 1976.

GOLDIAMOND I. Self-control procedures in personal behavior problems. Psychological Reports, 1965, 17, 851-868.

GOLDSTEIN A.P. Structured learning therapy: toward a psychotherapy for the poor. New York, Academic Press, 1973.

GOLDSTEIN A.P., Sprafkin R.P., Gershaw W.J. Ski1l-training for community living: applying structured learning therapy. New York, Pergamon Press, 1976.

GOLDSTEIN A.P., Sprafkin R.P., Gershaw W.J. Skills for adolescents. New York, Structured Learning Associates, 1977.

GOLDSTEIN A.P., Sherman M., Gershaw N.J., Sprafkin R.P., Glick B.

Training aggressive adolescents in prosocial behaviour. Journal of Youth and Adolescence, 1978, 7, 73-92.

GOLDSTEIN A.P. Priviliged communication. No. 064-26-0135, Syracuse University, New York, 1979.

GOLDSTEIN A.P., Sprafkin R.P., Gershaw N.J., Klein P. Skillstreaming the adolescent. Champaign, I11., Research Press, 1980.

GOLDSTEIN A.P. Psychological ski11 training, the structured learning therapy. New York, Pergamon Press, 1981.

GOULD R.E. Dr. Strangeclass or how I stopped worrying about the theory and began treating the blue-collar worker. American Journal of Orthopsychiatry, 1967, 37, 78-86.

GREENWALD $H$. Direct decision therapy. San Diego, California, Edits, 1973. 
GREY A.L. Social class and the psychiatric patient: a study in composite character. In: A.L. Grey (ed): Class and personality in society. New York, Atherton, 1969.

GUILFORD J.P. The nature of human intelligence. New York, McGraw-Hi11, 1967.

GUILFORD J.P., Hoepfner R. The analysis of intelligence. New York, McGraw Hil1, 1971.

GULICK R.M. Decision analysis as a learning strategy. In: 0'Neil H.F., Spielberger Ch. D. (eds.): Cognitive and affective learning strategies. New York, Academic Press, 1979.

HALEY J. Problem solving therapy. San Fransisco, Jossey-Bass, 1976. HALPERN G. Assessment of decision processes. Proceedings 75 th Annual Convention APA, 1967.

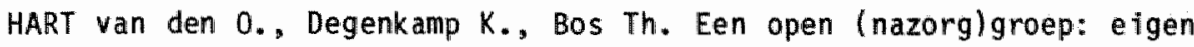
doelen stellen en ultwoeren. Maandblad Geestelijke Volksgezondheid, $1975,30,516-528$.

HASSELT van V.B., Hersen M., Bellack A.S. The validity of role-play tests for assessing social skills in children. Behavior Therapy, $1981,12,202-216$.

HEINE R.W., Trosman H. Initial expectations of the doctor-patient interaction as a factor in continuance in psychotherapy. Psychiatry, 1960, 23, 275-278.

HEITLER J.B. Preparation of lower-class patients for expressive group psychotherapy. Journal of Consulting and Clinical Psychology, $1973,41,251-260$.

HEITLER J.B. Preparatory techniques in initiating expressive psychotherapy with lower-class, unsophisticated patients. Psychologica1 Bulletin, 1976, 83, 339-352.

HEPPNER P.P. A review of the problem-solving literature and its relationship to the counseling process. Journal of Counseling Psychology, $1978,25,366-375$.

HERMANS H.J.M. Prestatiemotief en faalangst in gezin en onderwijs. Lisse, Swets en Zeitlinger, 1980.

HIGGINS R.L., Alonso R.R., Pendleton M.G. The validity of role-play assessments of assertiveness. Behavior Therapy, 1979, 10, 655-662. 
HOLLANDER J. Problemsolving Training. Intermediair, 1980, 16de jaargang, 28, 11, 1-9.

HOLLINGSHEAD A.B., Redlich F.C. Social class and mental 111 ness. New York, Willey, 1958.

HOMME L.E. Perspectives in psychology XXIV. Control of coverants, the operants of the mind. Psychological Record, 1965, 151, 501-511. HOOGDUIN $K$. Over het nemen van beslissingen. Im: Velden van der $K$. (ed.): Direktieve Therapie deel 2. Deventer, Van Loghun Slaterus, 1980.

HORAN J.J. Counseling for effective decision-making. Boston Mass., Duxbury Press, 1979.

HORNTON D.L., Turnage T.W. Human learning. Englewood Cliffs, New Jersey, Prentice Hall, 1976.

HOUTZ J.C., Feldhusen J.F. The modification of fourth graders problemsolving abilites. Journal of Psychology, 1976, 93, 229-237. INTAGLIATA J.C. Increasing the interpersonal problem-solving skills of an alcoholic population. Journal of Consulting and Clinical Psychology, 1978, 46, 480-498.

JACOBS D., Charles E., Jacobs T., Weinstein H., Mann D. Preparation for treatment of the disadvantaged patient. Effects on disposition and outcome. American Journal of Orthopsychiatry, 1972, 42, 666674 .

JACOBSON L.I. The effects of awareness, problem-solving ability and task difficulty on the acquisition and extinction of verbal behavior. Journal of Experimental Research in Personality, 1969, 3, 206-213.

JACOBSON N.S. Problem solving and contingency contracting in the treatment of marital discord. Journal of Consulting and Clinical Psychology, 1977, 45, 92-100.

JACOBSON N.S. Increasing positive behavior in severely distressed marital relationships: the effects of problem-solving training. Behavior Therapy, 1979, 10, 311-326.

JACOBSON N.S., Anderson E.A. The effects of behavior rehearsal and feedback on the acquisition of problem-solving skills in distressed and nondistressed couples. Behavior Research and Therapy, $1980,18,25-36$. 
JANIS J.L., Hoyt M.F. Increasing adherence to a stressful decision vila a motivation balance-sheet procedure: a field experiment. Journal of Personality and Social Psychology, 1975, 5, 833-839.

JASPERS J.P.C. Gijzelingen in Nederland. Lisse, Swets en Zeitlinger, 1980.

JOE V.C. Review of the internal-external control construct as a personality variable. Psychological Reports, 1971, 28, 619-640, Monograph Supplement 3 - v28.

JONES E. SOcial class and psychotherapy: a critical review of research. Psychiatry, 1974, 37, 307-320.

KAISER F.J. Entscheidungstraining. Bad Heilbrunn, Julius Klinkhardt, 1973.

KAZDIN A.E. Covert modeling and the reduction of avoidance behavior. Journal of Abnormal Psychology, 1973, 81, 87-95.

KENDALL P.C. On the efficacious use of verbal self-instructional procedures with children. Cognitive Therapy and Research, 1977, 1, $331-341$.

KENDALL P.C., Hollon S.D. Cognitive-behavioural interventions: Overview and current status. In: P.C. Kendall, S.D. Hollon (eds): Cognitive-behavioural interventions: theory, research and procedures. New York, Academic Press, 1979.

KENDALL P.C., Zupan B.A. Individual versus group application of cognitive-behavioral self-control procedures with children. Behavior Therapy, 1981, 12, 344-359.

KENDALL P.C., Hollon S.D. Assessment-strategies for cognitive behavioural interventions. New York, Academic Press, 1981.

KILMAN P.R., Albert B.M., Sotile W.M. Relationship between locus of control, structure of therapy and outcome. Journal of Consulting and Clinical Psychology, 1975, 43, 588 .

KILMANN P.R., Laval R., Wamlass R.L. Locus of control and percieved adjustment to 1 ife events. Journal of Clinical Psychology, 1978, $34,512-513$.

KILMANN P.R., Sotile, W.M. The effects of structured and unstructured leader roles on internal and external group participants. Journal of Consulting and Clinical Psychology, 1976, 44, 848-856. 
KOPPELAAR L., Vlaander G.P.J. Externe beheersing en het effect van therapie en training. Nederlands Tijdschrift voor de Psychologie, $1983,38,25-33$.

KRAWETZ S.P., Thomas K.R. A learning theory approach to counseling indecisfve clients. Rehabilitation Counseling Bulletin, 1974, 198-208.

KUENSTLER G. A planning group for psychiatric outpatients. The American Journal of Occupational Therapy, 1976, 30, 634-639.

LACHMAN R., Lachman J.L., Butterfield E.C. Cognitive psychology and information processing: an introduction. Hillsdale, New York, Erlbaum, 1979.

LANGE M. Drie vormen van behandeling in de geestelijke gezondheidszorg. Lisse, Swets en Zeit1inger, 1984.

LAZARUS R.S. Psychological stress and the coping process. New York, McGraw Hi11, 1966.

LAZARUS R.S. Cognitive behavior therapy as psychodynamics revisited. M.J. Mahoney (ed): Psychotherapy process. New York, Plenum Press, 1980.

LANDSHEER $H$. De bittere teleurstelling van de gedragsdiagnosticus. Gedrags therapie, 1983, 16, 153-159.

LEARY T. Interpersonal diagnosis of personality. New York, Ronald Press company, 1957.

LEE W. Formulating and reaching goals. Champaign 111 ., Research Press Company, 1978.

LEFCOURT H.M. Internal-external control of reïnforcement: a review. Psychological Bulletin, 1966, 65, 206-220.

LEFCOURT H.M. Locus of control. Hillsdale, New York, Lawrence Erlbaum Associates, 1976.

LERNER B. Therapy in the ghetto. Baltimore, Johns Hopkins University Press, 1972.

LEVENTHAL H., Meyer D., Nerenz D. The common sense representation of 111 ness danger. In: Rachman $S$. Contributions to medical psychology. London, Pergamon press, 1.980, 2, 7-30.

LIPINSKY D., Nelson R. Problems in the use of naturalistic observation as a means of behavioral assessment. Behavior Therapy, 1974, 5, $341-351$. 
LOCKE E.A. Is 'behavior therapy' behavioristic? Psychological Bulletin, 1971, 76, 318-327.

LORION R.P. Socio-economic status and traditional treatment approaches reconsidered. Psychological Bulletin, 1973, 79, 263-270.

LORION R.P. Patient and therapist variables in the treatment of lowincome patients. Psychological Bulletin, 1974a, 81, 344-354.

LORION R.P. Social class, treatment attitudes and expectations. Journal of Consulting and Clinical Psychology, 1974b, 42, 520.

LORION R.P. Research on psychotherapy and behavior change with the disadvantaged. In: Garfield S.L., Bergin A.E. (eds): Handbook of psychotherapy and behavior change, second edition. New York, Wiley, 1978.

LORISH R.C. Teaching counseling and problem-solving skills to disadvantaged young adults. Dissertation Abstracts International, 1975, 35, maart 9A, 5819 .

MAGOON J. Developing skills for educational and vocational problems.

In: Krumboltz J.D., Thoresen C.E. (eds): Behavioral counseling: cases and techniques. New York, Holt, Rinehart, Winston, 1969. MAHONEY M.J. Cognition and behavior modification. Cambridge Mass., Ballinger, 1974.

MAHONEY M.J. Reflections on the cognitive learning trend in psychotherapy. American Psychologist, 1977a, 32, 5-13.

MAHONEY M.J. Cognitive therapy and research: a question of questions. Cognitive Therapy and Research, 1977b, 1, 5-16.

MAHONEY M.J. Personal science: a cognitive learning therapy. In: A. Ellis en R. Grieger (eds): Handbook of rational psychotherapy. New York, Springer, $1977 \mathrm{C}$.

MAHONEY M.J. Psychotherapy process. New York, Plenum Press, 1980 . MAHONEY M.J., Arnkoff D.B. Cognitive and self control therapies. In: Garfield S.L., Bergin A.E. (eds): Handbook of psychotherapy and behavior change, second edition. New York, Wiley and Sons, 1978. MARZILLIER J., Eastman C. Continuing problems with self-efficacy theory: a reply to Bandura. Cognitive Therapy and Research, 1984 , $8,257-262$.

MAYO L.L., Norton R. The use of problem solving to reduce examination and interpersonal anxiety. Journal of Behavior Therapy and Experimental Psychiatry, 1980, 11, 287-289. 
MAYZNER M.S." Tresselt M.E. Anagram solution times: a function of letter order and word frequency. Journal of Psychology, 1958, 56, 376-379.

MCFALL R.M*, Marston A.R. An experimental investigation of behavior research in assertive training. Journal of Abnormal Psychology, $1970,76,2,295-303$.

MCFALL R.M. Analogue methods in behavioral assessment: Issues and prospects. In Cone J.D., Hawkins R.P. (eds.) Behavioral assessment. New York, Bruner/Maze 1, 1977.

MCGEOCH d.A. The psycholagy of human 1earning. New York, Longmans, Green, 1942.

MCGUIGAN F.J., Lunsden D.B. (eds.) Contemporary approaches to conditianing and learning. New York, Wiley, 1973.

MCGUIRE M.T., Sifneas P.E. Problem solving in psychotherapy. Psychiatric Quarterly, 1970, 44, 667-673.

MECHANIC D. Students under stress: a study in the social psychology of adaptation. New York, The Free Press of Glencoe, 1962.

MEICHENBAUM D. Cognitive behavior modification. Morristown, New York, General Learning Press, 1974.

MEICHENBAUM D. A self-instructional approach to stress management: a proposal for stress-inoculation training. In: J. Sarason, C.D. Spielberger (eds): Stress and anxiety. Volume 2, New York, Wiley, $1975,227-263$.

MEICHENBAUM D. A self-instructional approach to stress management: a proposal for stress-inoculation training. In: G. Spielberger, J. Sarason (eds): Stress and anxiety in modern 1ife. New York, Winston and Sons, 1976.

MEICHENBAUM D. Cognitive behavior modification. New York, Plenum Press, 1977.

MEILLO J., Goedhart A. Sociodrama, een sociale therapie. Maandblad Geestelljke Volksgezondheid, 1980, 35, 15-31.

MELTZHOF J., Kornreich M. Research in psychotherapy. New York, Atherton Press, 1970.

MENDONCA J.D., Siess T.F. Counseling for indectseveness: problemsolving and anxiety management. Journal of Counseling Psychology, $1976,23,339-347$. 
MERLUZZI Th.V., Rudy Th.R., Glass C.R. The information processing paradigm: implications for clinical sclence. In: Merluzzi Th.V., Glass C.R., Genest M.: Cognitive assessment. New York, The Guilford Press, 1981.

MEYERS J.J. Problem solving therapy with socially anxious children. Lisse, Swets en Zeftlinger, 1978.

MILLER J.F. Coping with chronic illness: overcoming powerlessness. Philadelphia, F.A. Davis Company, 1983.

MILLER N.E., Dollard J. Social learning and imitation. New Haven Connecticut, Yale University, 1941.

MILLER G.A., Gallanter E., Pribram K.N. P1ans and the structure of behavior. New York, Holt, Rinehart, Winston, 1960.

MINUCHIN S. Gezinstherapie. Utrecht/Antwerpen, Aula 511, Het Spectrum, 1973.

MINUCHIN S., Montalvo B., Guerney B.G. Jr., Rossman B.L., Schumer F.

Families of the slums. New York, Basic Books Inc., 1967. MURRAY E.J. Motivation and emotion. Englewood Cliffs, New Jersey, Prentice Ha11, 1964.

MYERS J.K., Bean L.L. A decade later: a follow-up of social class and mental 111 ness. New York, Wiley and Sons, 1968.

NEWELL A., simon H.A. Human problem solving. Englewood Cliffs, New Jersey, Prentice Hall, 1972.

NOVACO R. Anger control: the development and evaluation of an experimental treatment. Lexington, Mass, D.C. Heath, 1975.

NIJHOF G. Sociale ongelijkheid en psychische storingen. Nijmegen, Link, 1979.

O'CONNELL F.J. Jr., Duncan C.P. Anagram solving as a function of letter spacing. Psychological Reports, 1961, 8, 117-118.

ORLEMANS $H$. Cognities als 0 -factor in het SORKC-schema. Een reactie op de notitie van Aad Burger in dit tijdschrift. Gedragstheraple, $1983,16,161-165$.

ORMEL $H$. Moeite met leven of een moeilijk leven. Intermediair, 1981, $17,35,57-63$.

OSBORN A.F. Applied imagination: principles and procedures of creative problem-solving. 3rd ed., New York, Scribner, 1963. 
OVERALL B., Aronson H. Expectations of psychotherapy in patients of lower socio-economic class. American Journal of Orthopsychiatry, $1963,33,421-430$.

PARMES S.J., Noller R.G., Biondi A.M. (eds) Guide to creative action. New York, Scribner's, 1977.

PATTERSON G.R., Hops, H., Heiss R.L. Interpersonal skills training for couples in early stages of conflict. Journal of Marriage and the Family, 1975, 295-303.

PAVLOV J.P. Selected works. J. Gibbons (ed): Moscow, Foreign Languages Publishing House, 1955.

PAVLOV J.P. Conditiloned reflexes (1927). New York, Dover, 1960.

PHARES J.E. Locus of control in personality. Morristown, New York, General Learning Press, 1976.

PIAGET J. The moral judgement of the child. New York, Brace and World Inc., 1932.

PLATT J., Scura W.C., Hannon J.R. Problem-solving thinking of youthful incarcerated heroine addicts. Journal of Community Psychology, $1973,1,278-281$.

PLATT J., Spivack G. Problem-solving thinking of psychiatric patients. Journal of Consulting and Clinical Psychology, 1972a, 39, 148-151. PLATT J., Spivack G. Social competence and effective problem-solving thinking in psychiatric patients. Journal of Clinical Psychology, $1972 b, 28,3-5$.

PLATT J., Spivack G. Studies in problem-solving thinking of psychiatric patients: 1. Patient-control differences. II. Factoriall structure of problem-solving thinking. Proceedings of the 81 annual Convention of the American Psychological Association, 1973, 8, 463-464.

PLATT J., Spivack G. Means of solving real-1ife problems. 1. Psychiatric patients versus controls and cross-cultural comparisons of normal females. Journal of Community Psychology, 1974, 2, 45-48. POITRAS-MARTIN D., Stone G.L. Psychological education: a ski11-oriented approach. Journal of Counseling Psychology, 1977, 24, 153-157. PROKASY W.F. (ed.) Classical conditioning. New York, Appleton-CenturyCrofts, 1965. 
PIJPE G. Psychotherapie met de patient van laag ontwikkelingsniveau. Tijdschrift voor Psychotherapie, 1976, 2, 71-80.

QUEKELBERGE von R. Modelle kognitiver Therapien. In de reeks Fortschritte der klinischen Psychologie, 20, München, Urban en Schwarzenberg, 1979.

RAPAPORT L. The state of crisis: some theoretical considerations. Social Service Review, 1962, 36, 211-217.

REED R.P. Group psychotherapy effects on internal-external locus of control. Unpublished Ph.D. dissertation, University of New Mexico, 1975.

REIFF R., Scribner $S$. Issues in the new national mental health program relating to labor and low-income groups. In: F. Riessman, J. Cohen, A. Pearl (eds): Mental health of the poor. New York, Free Pres5, 1964.

RICHARDS C.R., Perri, M.G. Do self-control treatments last? An evaluation of behavioral problem-solving and faded counselor contact as treatment maintenance strategies. Journal of Counseling Psychology, 1978, 25, 376-383.

RIESSMAN F. New approaches to mental heal th treatment for labor and low-income groups: a survey. New York, National Institute of Labor Education, 1964.

RIESSMAN F., Cohen J., Pearl A. (eds.) Mental Health of the poor. New York, Free Press, 1964.

ROBIN A.L., Kent R., O'Leary K.D., Foster S., Prinz R. An approach to teaching parents and adolescents problem-solving communication skills. Behavior therapy, $1977,8,639-643$.

ROSEN L.W. Self-control program in the treatment of obesity. Journal of Behavior Therapy and Experimental Psychiatry, 1981, 12, 163166.

ROSENBERG M. Society and the adolescent self-image. Princeton, Princeton University Press, 1965.

ROSENTHAL D., Frank J.D. The fate of psychiatric clinic outpatients assigned to psychotherapy, Journal of Nervous and Mental Disorders, 1958, 127, 330-343.

ROTTER J.B. Social Learning and clinical psychology. Englewood Cliffs, New Jersey, Prentice Ha1 1, 1954. 
ROTTER J.B. Generalized expectancies for internal versus external control of reinforcement. Psychological Monographs, 1966, 80 , $1-28$.

ROTTER J.B. Some problems and milsconceptions related to the construct of internal versus external control of reinforcement. Journal of Consulting and Clinical Psychology, 1975, 43, 56-67.

RUBIN L.B. Worlds of pain. New York, Basic Books, 1976.

RUSSELL M.L., Thoresen, C.E. Teaching decilsion-making skills to children. In: Krumboltz J.D., Thoresen C.E. (eds.) Counseling methods. New York, Holt, Rinehart, Winston, 1976.

RYAN W. Psychotherapy for the poor: liberating or oppressive? Ongepubliceerde dissertatie. Universiteit van San Fransisco, 1972.

SANDERS G.J.E.M. Het gewone en het bijzondere van de homosexuele leefsituatie. Deventer, Van Loghum S1aterus, 1977.

SCANDURA J.H. Problem solving, a structured process approach. New York, Academic Press, 1977.

SCHMIDT W., Smart R.G., Moss M.K. Social class and the treatment of alcoholism. Toronto, University of Toronto Press, 1968.

SCHNEIDERMAN L. Sociall class, diagnosis and treatment. American Journal of Orthopsychiatry, 1965, 35, 99-105.

SCHOF IELD W. Psychotherapy: the purchase of friendship. Englewood Cliffs, New Jersey, Prentice Ha11, 1964.

SCHREURS P., Tellegen B., Vromans I., Willige van de G. De ontwikkeling van de Utrechtse copinglijst. Psychologisch Geschrift No. 83.01. IKPP, RU Utrecht, 1983 (intern rapport).

SCHREURS P., Tellegen B., Willige van de G. Gezondheid, Stress en

Coping: de ontwikkeling van de Utrechtse Coping Lijst. Tijdschrift voor Gedrag, 1984, 1.

SCHUERMAM J.A. Revalidatie van gedragsdeviaties bij cerebraal gestoorden. Proefschrift RL. Maastricht, september 1977.

SCHULTE D. Theoretische Grundlagen der Verhaltenstherapie. In: Handbuch der Psychologie. Bd.8/1, S 981-1026, Göttingen, 1977.

SCHWARTZ R.D., Higgins R.L. Differential outcome from automated assertion training as a function of locus of control. Journal of Consulting and Clintical Psychology, 1979, 47, 686-694. 
SELIGMAN M.E.P. HelpTessness: on depression, development and death. San Francisco, W.H. Freeman, 1975.

SELIGMAN M.E.P. Human helplessness: theory and applications. Academic Press, New York, 1980.

SHAPIRO M.D. A method of measuring psychological changes specific to the individual psychiatric patient. British Journal of Medical Psychology, 1961, 34, 151-155.

SHURE M., Spivack G. Means- ends thinking, adjustment and social class among elementary-school children. Journal of Consulting and clintcal Psychology, 1972, 38, 348-353.

SHURE M., Spivack G., Jaeger M. Problem-solving thinking and adjustment among disadvantaged pre-school children. Child Development, $1971,42,1791-1803$.

SIEGEL J.M., Spivack G. A new therapy for chronic patients. Behavior Therapy, 1976, 7, 129-130.

SKINNER B.F. The behavior of organisms. New York, Appleton Century, 1938.

SKINNER B.F. Science and human behavior. New York, MacMi11an, 1953. SLOVIC P., Fischoff, B., Lichtenstein, S. Behaviaral decision theory. Annual Review of Psychology, 1977, 28, 1-39.

SMITH. D. Trends in counseling and psychotherapy. American Psychologilst, $1982,37,802-809$.

SOBEY $F$. The nonprofessional revalution in mental health. New rork, Columbia University Press, 1970.

SPEEDIE S.M., Houtz J.C., Ringenbach S., Feldhusen J.F. Abilities measured by the Purdue Elementary Problem Solving Inventory. Psychological Reports, 1973, 33, 959-963.

SPIELBERGER C.D. de Nike L.D. Descriptive behaviorism versus cognitive theory in verbal operant conditioning. Psychological Review, 1966 , $73,306-326$.

SPIVACK G. Platt J.J., Shure M. The problem solving approach to adjustment. London, Jossey-Bass Publication, 1976.

SPIVACK G., Shure $M$. Social adjust of young children: a cognitive approach to solving real-life problems. London, Jossey-Bass Pub1 ishers, 1974. 
SROLE L., Langer T.S., Michael S.T., Opler M.K., Rennie T.A.C. Mental health in the metropolis: The Midtown Manhattan Study. New York, MCGraw-H111, 1962.

STAL P., Scheffer $W$. Umgaan met problemen. Nijmegen, ITS, 1982.

STONE G.H., Hinds K.C., Schmidt G.W. Teaching mental health behaviors to elementary school children. Professional Psychology, 1975, february, 34-40.

STUFKENS T. Een introductiecursus voor Psychotherapie. Utrecht, dissertatie RU, 1977.

SUINN R.M., Richardson A. Anxiety-management training: a non-specific behavior therapy program for anxiety control. Behavior Therapy, $1971,2,489-510$.

SWAAN de A., Gelderen van R., Kense $V$. Het spreekuur als opgave. Socfologie van de psychotherapie 1I. Utrecht, Aula boeken, 662, Het spectrum, 1979.

THOMAS E.J., O'Flaherty K., Borkin J. Coaching marital partners in family decision-making. In: Krumboltz J.D., Thoresen C.E. (eds.) Counseling methods. New York, Holt, Rinehart, Winston, 1976.

THORESEN C.E., Mahoney M.J. Behavioral self-control. New York, Holt, Rinehart, Winston, 1974.

THORNDIKE E.S. Animal intelligence: an experimental study of the assoclative processes in animals. Psychological Review Monographs, $1898,8,2-4$.

TORRANCE E.P., Meyers R.E. Creative learning and teaching. New York, Dodd, 1970.

TROWER P., Bryant B., Argyle M. Social skills and mental health. Pittsburgh, University of Pittsburgh Press, 1978.

UNDERWODO B.J., Schultz R.W. Meaningfulness and verbal learning. Chicago, Lfppincott, 1960.

URBAIN E.S., Kendall P.C. Review of social-cognitive problem-solving interventions with children. Psychological Bulletin, 1980, 88, 109-143.

VELDEN van der $K$. ., Vreeken $T$. Recht op hulp: twee notities over de opzet van een matschappel ljk relevant RIAGG in Rotterdam. Maandbl ad Geestelijke Volksgezondheid, 1977, 32, 760-772. 
WALLACE W.G., Horan J.J., Baker S.B., Hudson G.R. Incremental effects of modeling and performance feedback in teaching decision-making counseling. Journal of Counseling Psychology, 1975, 22, 570-572.

WASKOV I.E., Parloff M.B. (red.) Psychotherapy change measures. Washington, 1975 NIMH.

WESTERLAAK van J.M., Kropman J.A., Collaris J.W.M. Beroepenklapper Nijmegen, ITS, 1975.

WHATSON D.L., Tharp R.G. Self-directed behavior: self-modification for personal adjustment. 2nd edition, Monterrey, Brooks-Cole, 1977. WILLIAMS R.L., Long J.D. Toward a self-managed life style. Boston, Houghton Mifflin Company, 1975.

WILLEMS M. e.a. Paper project inzichtgevende psychotherapie met arbeiders. IMP Amsterdam, 1976.

WILLIGE van de G., Schreurs P., Tellegen B. Het meten van coping gedrag: de Utrechtse Copinglijst. Intern verslag Vakgroep Ki inische Psychologie Utrecht, januari 1983.

YABROFF. Learning decision making. In: Krumboltz, J.D., Thoresen C.E. (eds.) Behavioral Counseling: cases and techniques. New York, Holt, Rinehart, Winston, 1969.

YALOM, J.D. The theory and practice of group psychotherapy. Second edition, New York, Basic Books Inc. Publishers. 1975. 
Biflage I: Protocol voor de vaardigheid "dagelijkse problemen aanpakmen $n^{\text {tI }}$

De vaardigheldstherapie "dagelijkse problemen aanpakken" omvat 4 weke11jkse bijeenkomsten van 2 uur onder leiding van 2 therapeuten, die elkaar afwisselen wat de uitvoering wan de verschillende programmaonderdelen betreft. De therapeuten maken vooraf duldelijke afspraken over de onderlinge rolverdeling. Een aamtal van 6 clienten per theraple lijkt optimal zowel wat de modelfunctie betreft alsook met het oog op de per bijeenkomst beschikbare tijd. De bijeenkomsten worden alsvolgt gestructureerd:

ZITTING 1

0.00-0.20 u. KENNISMAKING EN INTRODUCTIE

1. Kort doel en duur van de groep aangeven

2. Kennismaking door middel van het uitwisselen van namen

3. Nadere toelifchting op het doel. Deelnemers duidelijk maken dat

a. het erom gat de deelnemers een strategie (=systematische manier van omgaan met) aan te leren met behulp waarvan ze problemen adequaat kunnen aanpakken.

b. de term probleem altijd verwijst naar problematische situaties. Het gaat om situaties die zich plotseling voordoen en waar men geen gewoonte- of routine-oplassing voor voorhanden heeft. De therapeuten dienen duidelijk aan te geven dat de aandacht vooral gericht wordt op probleemsituaties, die paniek, apathie of een andere, meestal inadequate, reactiewijze bij het betreffende individu oproepen. Doel van de bijeenkomsten is de deelnemers adequater met soortgelijke situaties te leren omgaan. 
c. deze therapie niet beoogt hẽt centrale probleem of symptoom van de deelnemers voor hen op te lossen.

d. er tijdens de bijeenkomsten vooral geoefend. $z$ al worden door de deelnemers.

e. deze oefeningen alledaagse situaties zullen betreffen uit de eigen leefsituatie.

$f$. deze oefeningen zullen verlopen in een volgorde van makkelijk naar steeds lets moeilijker.

4. Eerste inventarisatie van probleemsituaties. De therapeuten geven aan om wat voor soort probleemsituaties het gaat door zelf een aantal voorbeelden te noemen (zie lijst standaard probleemsituaties p.221 e.v.). Elke deelnemer wordt gevraagd 1 à 2 voor hem relevante alledaagse probleemsituaties op te noemen.

$0.20-0.40$ u. VIDE0-MODELING PLUS DIDACTISCHE INSTRUCTIE

1. Introductie van de vaardigheid op video door de autoriteit. Men laat de eerste voorbeeldsituatie aan de deelnemers zien warin de betreffende leerpunten niet worden toegepast.

2. Nabespreking van het videovoarbeeld aan de hand van de volgende vragen:

* wat gebeurde er?

* wat vindt u van de getoonde reactie-wijze?

* herkent u deze reactie-wijze?

3. Introductie van de leerpunten op video. Men laat de deelnemers het eerstvolgende video-voorbeeld zien, waarin de betreffende leerpunten wèl worden toegepast.

4. Nabespreking van het zojulst getoonde video-voorbeeld aan de hand van de volgende wragen:

* wat gebeurde nu?

* zag u de leerpunten?

In deze nabespreking dienen de 5 leerpunten, punt voor punt, nagevraagd te worden bij de clienten. 
5. Ter didactische instructie van de impliciete leerpunten moet door de therapeuten benadrukt worden dat:

a. het zinvol kan zijn eerst na te denken en daarna pas lets te gaan doen.

b. men bij aefenimgen in het aanpakken van problemen het beste eenvoudig en gemakkelijk kan beginnen.

c. problemen/problematische situaties, een normal (onder)deel vormen van het dagel ljks leven waarmee iedereen op zijn tijd geconfronteerd wordt.

d. men problemen niet wit de weg dient te gaan maar well aan te pakken en op te lossen.

e. een bepaald probleem/een bepaalde problematische situatie altijid meerdere oplassingen kent.

f. dè (=enige, goede) oplossing niet bestaat.

g. wat voor de een een goede oplossing vormt, voor een ander een slechte kan zijn.

$h$. het bij het maken van een keuze uit moge 1 ijke oplossingen van groot belang is, dat de voordelen opwegen tegen de nadelen.

De in a $t / m$ h beschreven impliciete leerpunten worden regellmatig herhaald door de therapeuten, zodat ze elke zitting wel een aantal keren onder de aandacht komen.

$0.40-0.45 \mathrm{u}$. Korte toelichting en samenvatting met betrekking tot 1 eerpunt 1 en 2.

$0.45-0.55$ u. MODELING door een van befde THERAPEUTEN met betrekking tot 1 à 2 standaardsituaties: uitsluitend wat betreft leerpunt 1 en 2 (voor 1ijst standaard-situaties zle p.221 e.v.l. 
0.55 - 1.50 u. GEDRAGSOEFENING door de CLIENTEN waarbij elke deelnemer een beurt krijgt met betrekking tot een standaard-situatie (p.221 e.v.) uitsluitend wat betreft leerpunt 1 en 2 . De client die de beurt heeft, gaat vö̈r de groep in een stoel zitten. De gedragsoefeningen van de deelnemers worden beurtelings geleld door de therapeuten. Terwijl een van hen de betreffende client instrueert, ondervraagt en ondersteunt, noteert de ander op de flap-over de wijze waarop leerpunt 1 en 2 worden ingevuld. De cllient, die de beurt heeft, zit en profile voor de groep: duidelijk zichtbaar voor de mede-groepsleden en therapeuten met goed uitzicht op het bord met leerpunten en op de flap-over. Teneinde discussie met groepsgenoten tijdens de oefening te voorkomen, zit de client half met zijn rug naar de groep gekeerd (= "en profile"). Wat de PROBLEEMDEFINITIE - leerpunt 1 - betreft, geldt dat deze aan 3 eisen moet voldoen:

a. het betreffende probleem moet in concrete termen gesteld zijn.

b. de probleemdefinitie moet alle relevante felten omvatten.

c. dat aspect aan het probleem waar men iets aan wenst te veranderen, moet expliciet in de probleemdefinitie zijn opgenomen.

De wijze waarop men een probleem definieert, blifkt gevolgen te hebben voor de richting warin men oplossingen bedenkt. De nu volgende probleemsituatie diene daarbij als voorbeeld.

Stel u voor:

$U$ hebt een afspraak met uw huisarts. I wilt er op de fjets heengaan. U stapt het fletsenhok binnen en zlet tot uw schrik dat uw flets een platte band heeft. 
Het in deze situatie aanwezige probleem kan men op minstens 3 verschillende manieren definiëren:

a. probleem-definitie 1: Uw fiets is kapot. Hoe kunt u ervoor zorgen dat die weer gerepareerd wardt?

b. probleem definitie 2: U wilt op tijd bij uw huisarts zijn teneinde de afspraak te laten doorgan. Hoe speelt u dat klaar?

c. probleem definitie 3: $U$ wilt zo snel mogelijk aan de huisarts doorgeven dat $u$ te lat komt. Hoe kunt $u$ dit aampakken?

Tijjens de oefeningen in de groep dient de deelnemers duidelijk te worden gemaakt dat men een en hetzelfde probleem op meerdere wijzen kan verwoorden. De persoon die de beurt heeft, bepalt voor welke probleemdefinitie hij kiest en dus ook in welke richting hij oplossingen gaat zoeken.

Bij leerpunt 1 "Ga na wat precies het probleem is' heeft de therapeut tot taak de clienten bij de concretisering van hun probleem behulpzaam te zijn door het stellen van uragen, gericht op concretisering (wie, wat, waar, wanneer). Dit geldt voor alle zittingen.

Achtereenvolgens krijgt elk groepslid de opdracht leerpunt 1 en 2 toe te passen ten aanzien van een standaardsituatie (zie lijst op p.221 e.v.).

Leerpunt 2, het bedenken van alernatieven, kan men afwisselend groepsgewijs en individueel oefenen. Herhalde oefening van deze leerstappen tijdens de eerste zitting is van groot belang, waarbij de therapeuten er zorg voor dienen te dragen dat de deelnemers er plezier in krijgen zoveel mogelijk oplossingen te bedenken zonder daarbij enige vorm van selectie toe 
te passen. Ook oplossingen die in eerste instantie weinig reëel en/of gebruikelijk lijken, worden in de rij van mogelijke oplossingen opgenomen. Doel daarvan is het creatief denken te bevorderen.

$1.50-1.60$ u. HUISWERK

1. Introductie hui swerkbeginsel

2. Introductie huiswerkboekje

3. Opgave eerste hui swerk:

a. kijjk hoe anderen in uw omgeving met problemen omgaan: wat valt $u$ daaraan op in termen van de leerpunten?

b. noteer aan het eind van elke dag wat voor probleemsituaties er op die dag hebben plaatsgevonden (dagboek).

c. pas op een van deze situaties leerpunt 1 en 2 toe.

\section{ZITTING 2}

$0.00-0.30$ u. HUISWERKBESPREKING:

1. Ieder krijgt een beurt.

2. Adequaat huiswerk gedrag wordt positief bekrachtigd.

3. Bij niet gemaakt huiswerk 1 aten de therapeuten hun teleurstelling blijken.

4. De therapeuten noteren op de flap-over per client welke leerpunten wèl en welke nièt werden gerealiseerd. Niet-gereal iseerde leerpunten worden in de loop van de zitting extra geoefend.

5. Modeling door groepsgenoten en didactische instructie van therapeuten met betrekking tot inadequaat hull swerk. 
$0.30-0.50$ u. VIDEO-MODELING PLUS DIDACTISCHE INSTRUCTIE

Video-voorbeeld 2 wordt getoond - mèt en zonder leerpumten - en nabesproken volgens de procedure beschreven bij zitting 1 .

$0.50-1.00$ u. MODELING DOOR EEN THERAPEUT

Leerpunt $1 \mathrm{t} / \mathrm{m} 5$ worden door een therapeut toegepast op een standaard probleemsituatie (zle lijst op p.221 e.v.). Dezelfde situatie kan worden gebruikt als bij sessie 1: nu met toepassing van àlle leerpunten.

$1.00-1.45$ u. GEDRAGSOEFENING DOOR DE CLIENTEN

1. De clienten $k r i j g e n$ ieder een beurt met betrekking tot de standaardsituaties zoals gebruikt in sessie 1. Nu met de opdracht leerpunt $1 \mathrm{t} / \mathrm{m} 5$ toe te passen.

2. Clienten krijgen elk een beurt met als opdracht leerpunt $1 \mathrm{t} / \mathrm{m} 5$ toe te passen met betrekking tot de huiswerksituatie uit zitting 1 . De opstelling tijdens deze beurten is gelijk aan de opstelling in zitting 1.

3. Met betrekking tot leerpunt 1 "ga na wat precies het probleem is" geldt dat de therapeut erop dient toe te zien dat het probleem zo duidelijk en concreet mogel ijk geformuleerd wordt door de betreffende client.

4. Met betrekking tot leerpunt 2 "bedenk een aantal oplossingen" geldt dat de client leert zelf een aantal, in ieder geval meer dan 1, oplossingen te bedenken. Bij dit leerpunt kan de groep worden ingeschakeld om degene die de beurt heeft te tonen dat men voor het gestelde probleem inderdaad een reeks oplossingen kan bedenken.

5. Met betrekking tot leerpunt 3 "zet de voor- en nadelen van elke oplossing op een rif" geldt dat de deelnemers leren voor- en nadelen te benoemen 
en vervolgens tegen elkaar af te wegen. De gevolgen van een bepaaide oplossingen kan men steeds opdelen in korte en lange-termijn gevolgen en in gevolgen voor de persoon zelf versus gevolgen voor zijn omgeving.

6. Met betrekking tot leerpunt 4 "kies de oplassing die je het best past" geldt dat ellke deelnemer moet leren de voor hem meest passende oplossing te kiezen. Wanneer de betreffende persoon het moeilijk vindt om een keuze te maken, kunnen de therapeuten een afwegingssysteem demonstreren met behulp van het toekennen van cijfers c.q. het toekennen van plussen en minnen.

7. Met betrekking tot leerpunt 5 "breng die oplossing in praktijk" geldt dat deze stap door de betreffende persoon zo mogelijk kort maar krachtig wordt ingeoefend tijdens de groepsbijeenkonsten. Er vindt echter geen uitgebreide interpersoonlijke vaardigheidstraining plaats. Bij aperte interpersoonlijke vaardigheidstekorten is deelname aan interpersoonlijke vaardigheidstherapieên aangewezen.

\section{$1.45-1.60$ u. HUI SWERK}

Aan het eind van deze tweede zitting krijgen deelnemers de volgende huiswerkopdrachten mee:

1. Noteer aan het eind van elke dag welke probleemsituaties $u$ heeft meegemaakt. Deze situaties zullen tijdens de volgende bijeenkomst als oefenmateriaal worden gebruikt.

2. Kies een van de onder punt 1 bedoelde situaties uft en pas daarop leerpunt $1 \mathrm{t} / \mathrm{m} 5$ toe. 
$0.00-0.30 \mathrm{u}$. HUISWERKBESPREKING

Deze verloopt op dezelfde wijze als beschreven bij zitting 2 .

$0.30-0.50$ u. SCHRIFTELIJKE GEDRAGSOEFENING

De deelnemers krijgen van de therapeuten de opdracht, jeder voor zich, leerpunt $1 \mathrm{t} / \mathrm{m} 5$ toe te passen op éen van de standaardsituaties, gepresenteerd door een van beide therapeuten. Men werkt allen dezelfde situatie uit, met of zonder pen en papier als hulpmiddel.

$0.50-1.00$ u. NABESPREKING

Kort verslag van de eerder uitgewerkte situatie per persoon in de groep.

$1.00-1.45$ u. GEDRAGSOEFENING

Elk der deelnemers krijgt een beurt met daarbij als opdracht leerpunt $1 \mathrm{t} / \mathrm{m} 5$ toe te passen op een door henzelf ingebrachte situatie. Aan nog niet begrepen leerpunten wordt zonodig extra aandacht besteed door modellen in te schakelen en door extra oefenbeurten te geven. De nog niet begrepen leerpunten kan men desgewenst aok ieder op zich nog een keer oefenen: los van elkaar. De opstelling tijdens deze gedragsoefening werd reeds beschreven bij zitting 2 . Aan de bekrachtiging van gewenst gedrag wordt expliciet aandacht besteed door de therapeuten.

$1.45-1.60$ u. HUISWERK

Als huiswerk krijgen de deelnemers deze1fde opdrachten mee als bij zitting 2 . 
$0.00-0.30 \mathrm{u}$. HUISWERKBESPREKING

Deze verloopt op dezelfde wijze als aangegeven bij zitting 2 en 3.

\section{$0.30-1.30$ u. GEDRAGSOEFENING}

Elke deelnemer krijgt een beurt met een standaardsituatie in spel-vorm. Nadat een van de therapeuten aan de rand van het speelvlak', in front van de groep, de betreffende situatie in grote 1 ijnen heeft geschetst, wordt deze vervolgens uitgespeeld, gebruik makend van in de ruimte aanwezige attributen. Medegroepsleden treden zonodig als antagonist op. De client krijgt als opdracht de betreffende leerpuntensequentie tore te passen op het probleem dat tijdens de spelsituatie zal ontstaan. Het spel verloopt zodanig dat het verrassings- c.q. overrompelingseffect dat probleemsituaties in het dagelijks leven kenmerkt, behouden blijft. De client kan op deze wijze ervaring opdoen met het inoefenen van het zgn. "stop en denk" principe door letterlijk en figuurlijk afstand te nemen van de betreffende situatie. Door op de zgn. denkmat (=een welomschreven plaats in de ruimte om rustig na te denken) te gaan staan, heeft hij op ieder gewenst moment de mogelijkheid voor zichzelf ruitmte te creëren om de probleem-oplos-strategie voor zichzelf, dat will zeggen in gedachten, toe te passen.

Gedrag, adequat conform de leerpunten, wordt expliciet bekrachtigd door de therapeuten.

$1.30-1.60 u$. HUISWERK LAATSTE ZITTING

Aan elk van de deelnemers wordt naast het hui swerk, zoals in zitting 2 en 3 beschreven, tenslotte ook een soort continuë hwiswerkopdracht meegegeven. Daarbif 
wordt nagegaan en afgesproken hoe elk van de cllenten voor zich ervoor kan zorgen, dat men de nieuw geleerde vaardigheid in de eigen leefomgeving blijft toepassen, ook na afloop van de groepsbijjeenkomsten. 
Stel u voor:

1. U staat voor uw huisdeur en merkt dat u geen huissleutel heeft. Er is niemand thuis.

2. U bent in een grote zelfbedieningszaak. Het is een paar minuten voor sluitingstijd. U hebt nog een paar boodschappen gedaan voor het bezoek van vanavond. Tenwijl $u$ in de rif staat voor de kassa, merkt $u$ dat u geen geld bij u heeft.

3. U hebt om 10 uur een afspraak op het arbejisbureau. Om kwart voor 10 pakt u u'w fiets en merkt dat eem band plat staat.

4. U krijgt anverwacht bezoek. Het is 16.00 uur 's middags. U wilt koffie gaan zetten en merkt dat de koffie op is.

5. U moet om 9.00 uur bij de huisarts zijn. Om 8.30 uur krijgt u een telefoontje van V\&D dat ze een huishoudel ijk apparaat waar $u$ al een hele tijjd op zit te wachten in de loop van de ochtend komen brengen.

6. $U$ bent uitgenodigd op een verjaardagsfeestje. Het is zondagavond. Als $u$ om 8 uur op het punt staat naar de jarlge toe te gaam, dringt het tot $u$ door dat $u$ helemal vergeten bent een cadeautje te kopen.

7. U staat op het punt de deur uit te gaan op weg naar een afspraak met uw huifsarts. U hebt uw jas reeds in de hand, op dat moment ziet $u$ een bekende auto voor uw huils stoppen. Familieleden uit Venlo blijken u met hun bezoek te komen verrassen.

8. U hebt dringend contant geld nodig. Het is 15.45 uur. Bif de bank aangekomen leest $u$ op een papier op de deur "Wegens omstandfgheden gesloten' . 
9. Uw auto is voor een beurt in de garage. U hebt afgesproken de auto om 13.30 uur op te halen. Als u om 13.30 uur de garage binnenstapt, gaat de monteur net aan uw auto beginnen. U hebt om 14.00 uur een afspraak op uw werk.

10.U draagt een bril met sterke glazen. U hebt boodschappen gedaan in de stad. Op weg naar de auto wordt $u$ overwallen door een fikse regenbui. U stapt uw auto in, pakt uw brit wan uw neus om deze met uw zakdoek schoon te vegen. Plotseling merkt u dat uw bril in twee stukken is gebroken.

11.U staat bij een tankstation ergens 1 angs de autoweg. U bent klaar met tanken. U stapt het kantoortje binnen om te betalen. De man achter de kassa reikt $u$ het bonnetje aan en zegt: 'Dat is dan 54 gulden 80 mijnheer". Op dat monent merkt u dat u géen geild of cheques blj $u$ heeft om te betalen.

12.U gat naar een receptile ter ere van ëén van uw collega's. U hebt extra zorg besteed aan uw k1eding. U loopt vaor deze gelegenheid op hoge hakken. op het moment waarop $u$ de reeds druk bezette zaal binnenstapt, breekt de hak van uw rechterschoen af.

13. Het is 17.00 uur. U wilt nog snel even boodschappen doen voor het avondeten en merkt dat u niet gemoeg geld in huis heeft.

14. Het is woensdagavond 20.15 uur. U hebt de t.v. aanstaan. U verheugt zich op de Europacup-wedstrijd die am 20.30 uur begint. Om 20.20 uur valt het beeld weg.

15. Een kennis van $u$ heeft het wafelijzer van $u$ gelleend. $U$ wilt het graag terug hebben. De kennis heeft geen telefoon, $U$ bent al een aantal keren bij haar aan de deur geweest, maar u treft steeds niemiand thuts. 
16. Het is 10 voor acht's avonds. U heeft met een vriend afgesproken dat hij $u$ om acht uur komt afhalen om samen naar een feestje te gaan in een dorp $20 \mathrm{~km}$ verderop. De telefoon gaat. Het $1 \mathrm{~s}$ ww vriend die meedeelt, dat hij verhinderd is vanavond. U heeft zelf geen auto.

17. Een vriendin, die $u$ al lang niet meer gezien hebt, belt op en zegt dat ze vanavond langs wil komen. U hebt helemaal geen zin in haar bezoek.

18.U hebt een huisarts waar $u$ al 1 ang niet meer tevreden over bent. $U$ wilt eigenlijk een ander.

N.B. De therapeuten kunnen deze lijst zelf verder aanvullen aan de hand van eigen ervaringen en naar aanleiding van ervaringen tijdens de groepsbijeenkomsten. 
Bijlage II: Protocol voor de vaardigheid "veranderingen aanpakken"

De vaardigheidstherapie "veranderingen aanpakken" neemt 8 bijeenkomsten van elk 2 uur in beslag. Deze bijeenkomsten worden als volgt gestructureerd:

\section{ZITTING 1}

$0.00-0.20 u_{*}$ RENNISMAKING EN INTRODUCTIE

1. Kort doel en duur van de cursus aangeven.

2. Kennismaking door middel van het aan elkaar uitwisselen van namen.

3. De therapeuten 1 ichten het doel van de cursus toe, waarbij zij duidelijk maken:

a. dat het de bedoeling is een generaliseerbare strategie (= systematische manier van omgaan met) voor het aanpakken van veranderingen aan te leren en wel via het met elkaar aanpakken van een aantal zelfgewenste veranderingen na elkaar in de tijd.

b. dat deze vaardigheid uiteenlopende onderwerpen en levensgebieden kan betreffen, zoals:

* veranderingen ten aanzien van de woonsituaties, bijvoorbeeld de inrichting van huis, tuin, buurt, etc.

* veranderingen in dagelijkse activiteiten, bezigheden c.q. Werkzaamheden: bultenshuis zowe l als thuis, betaald èn onbetald.

* veranderingen in vrije-tijdsbesteding, bijvoorbeeld wat betreft hobby's, sport en ontspanning.

* veranderingen in relaties met anderen: collegae, partner, (schoon)familie, vrienden, kennissen, buren.

* veranderingen ten aanzien van kennisniveau en 
deskundigheden, dat wil zeggen in opleidingsen/of scholingsniveau.

* veranderingen van leefwijze zoals bijvoorbeeld eet-, rook-, drink- en slaapgewoonten.

Voor de therapeuten is het van belang te weten dat:

- gewoontes die de persoon als niet onder eigen controle staand ervaart. niet voor behandeling in dit programma in aanmerking komen.

- dwangfenomenen, hyperventilatie, massale verslavingsproblematiek en evidente fobische symptomen voor behandeling moeten worden doorverwezen voor gedragstherapie specifiek gericht op de behandeling van dergelijke symp tomati ek.

- de vaardigheidstherapie "veranderingen aanpakken" het meest geëigend is voor die clienten, die nadat de ergste druk van hun problemen c.q. klachten is afgehald weer ruimite ervaren voor constructieve activiteften. Het gaat dus om clienten die weer iets willen (opbouwen).

- deelnemers aan deze vaardigheidstherapie duidel $i j k$ moet worden gemaakt dat het aanpakken van verandering niet vanzelf verloopt maar inspanning van clienten vereist wat betreft denkwerk èn daadwerkelijke activiteit(en); alsook enige mate van zelf-controle en doorzettingsvermogen.

4. Inventarisatie van veranderingen: aan elke deelnemer wordt gevraagd twee veranderingen op te noemen, waar hij aan wil werken. Deze opties worden door een van beide therapeuten op de flap-over genoteerd. 
1. De therapeuten leggen de deelnemers uit dat het "aanpakken van veranderingen" wit drie fasen bestaat, te weten:

a. een doel stellen

b. een plan maken

c. aan de slag gaan

2. Ook wordt duidelijk gemaakt dat voor elk van deze fasen drie leerpunten gelden. De waardigheid "veranderingen aanpakken" omvat in totalitteit dus 9 leerpunten.

3. De therapeuten geven aan, dat tijdens deze eerste zitting de eerste fase, met behulp van leerpunt 1 $t / m 3, z a 1$ worden uitgelegd en geoefend.

4. Ter video-modeling wordt vervolgens de introductie vam de vaardigheid door de autoriteit getoond, als ook het eerste voorbeeld van "een doel stellen".

5. Het eerste video-voorbeeld wordt nagesproken aan de hand van de nu volgende vragen:

* wat zag u gebeuren?

* zag ul leerpunt $1,2,3$ ?

N.B. De leerpunten worden na elkaar nagevraagd met behulp van directe, gerichte vragen aan met name genoemde deelnemers.

6. Vervolgens worden video-voorbeeld 2 en 3 afgehandeld op dezelfde wijze als besproken onder punt 5 .

$B i j$ het bespreken van de leerpunten dienen de therapeuten de deelnemers erop te attenderen, dat bij het "aanpakken van veranderingen" naast de leerpuntensequentie zoals aangegeven op het bord met leerpunten, de volgende, zgn. "impliciete" leerpunten van belang zijn:

* bezint eer ge begint

* veranderen kan maar kost duidelijk inspanning

* men moet nlet alleen denken maar ook doen 
* geef niet tè snel op als er onverwacht lets mis gat.

Deze didactische instructies dienen in de $100 p$ van de bijeenkomsten regelmatig te worden herhald.

\section{$0.50-1.40$ u. GEDRAGSOEFENING}

1. Ter inoefening van de leerpunten 1,2 en $3 \mathrm{krijgen}$ de deellnemers achtereenvolgens de apdracht deze leerpunten toe te passen op de makkelijkste van de twee eerder door hen aangegeven en op de flap-over genoteerde veranderingen.

2. Terwijl de ene therapeut de gedragsoefening in de vorm van een socratische dialoog in front van de groep leidt, makt de ander leerpuntsgewijs aantekeningen op de flap-over.

3. De client die de gedragsoefening uitvoert, zit tegenover de therapeut op het speelvlak im front van de groep met het gezicht naar de flap-over en het bord met leerpunten. Ten opzichte van de groep zitten ze "en profile". Dit om te voorkomen dat er tijdens de gedragsoefening discussie ontstaat met mede-groepsleden.

Ten aanzlen van het "stellen van een doel" dienen de therapeuten er rekening mee te houden dat:

a. men clifenten doelen leert stellen, die haalbaar voor hen zijh. Tè hoog gestelde doelen leiden tot faalervaringen met alle demotiverende effecten vandien.

b. men de clilent zijn ejgen doelen moet laten klezen. De therapeut moet samen met de client zlen uit te vinden wat deze wil en wat dlens mogelijkheden daarin zijn. ook het opleggen van doelen door de therapeut aan de client verhoogt de kans op faalervaringen en werkt demotiverend. 
c. de doelen en wensen zo concreet mogelijk geformul eerd worden: wat wil men, hoe, waar, wanneer en met wle. Steeds rekening houdend met de haalbaarheid van een en ander voor de betreffende persoon.

d. oordelen van de deelnemers over zichzelf zoveel mogel ijk gekoppeld moeten worden aan specifieke situaties.

e. de gedragingen en instelling van de persoon zelf steeds als onderwerp van verandering dienen, aangezien controle over anderen c.q. de omgeving van de therapiegroep uit niet mogelijk is.

f. men de deelnemers wil leren hun onvrede om te zetten in activiteit(en).

g. de veranderingsdoelen liefst in positieve richting worden geformuleerd. Bijvoorbeeld: leerpunt 3 formuleert men bij voorkeur in de zin van "ik wil meer..." in plaats van "ik wil minder..." luit onderzoek is immers bekend dat het toepassen van beloningsprocedures meer kans op succes geeft dan het toepassen van strafprocedures. Bij "ik wil meer..." kan men voornamelijk gebruik maken van beloningsprocedures; bij "ik wil minder..." komt men vaak niet om het toepassen van "straf"procedures heen).

$1.40-1.60$ u. HUISWERK

1. Introductie van huiswerkbeginsel en huiswerkboekjes.

2. De therapeuten geven de volgende twee hui swerkopdrachten mee:

a. kijk hoe anderen "veranderingen aanpakken" en wat daaraan opvalt in termen van de reeds behandel de leerpunten

b. pas leerpunt $1 \mathrm{t} / \mathrm{m} 3$ toe op de verandering die eerder tijdens deze zitting op de flap-over werd vastgelegd maar nog niet geoefend. 
$0.00-0.40 \mathrm{u}$. HUISWERKBESPREKING

1. Elke deelnemer krijgt een beurt.

2. Adequaat huiswerkgedrag wordt expliciet bekrachtigd door de therapeuten.

3. Bij nilet gemaakt huiswerk laten de therapeuten hun teleurstelling blijken.

4. De therapeuten noteren op de flap-over per client welke leerpunten wel/niet begrepen blijken. Niet begrepen leerpunten worden in de loop van de zitting extra geoefend.

5. De therapeuten wisselen elkaar af in het ondervragen van $c l$ ienten en het maken van leerpuntsgewijze notities op de flap-over.

\subsection{0 - 1.00 u. VIDEO-MODELING EN DIDACTISCHE INSTRUCTIES}

1. De therapeuten geven duidelijk a an dat nu de tweede fase uit het veranderingsproces aan de orde is, $\mathrm{n}$ 1.: "een plan maken".

2. Video-modeling: deze verloopt op dezelfde wijze als beschreven bij zitting 1 .

3. Dok de nabespreking van de drie video-voorbeelden van "een plan maken" verloopt op dezelfde wijze als bij zitting 1 .

\section{$1.00-1.50$ u. GEDRAGSOEFENING}

Deze verloopt op dezelfde wijze als beschreven bij zitting 1. Ten aanzien van de leerpunten van "een pl an maken" geldt, dat:

a. leerpunt 4: "bedenk manieren waarop je het in leerpunt 3 gestelde doel kunt verwezenlijken" ook apart geoefend kan worden - individueel en/of "en groupe" - teneinde de groepsdeelnemers meerdere oplossingen te leren bedenken. 
b. de overige groepsleden tijdens de individuele gedragsoefeningen worden aangespoord actief mee te denken over alternatleve mogelijkheden am het gestelde doel te bereiken. De door de groep angedragen mogelijkheden worden door een van de therapeuten op de flap-over genoteerd en vervolgens op haalbaarheid beoordeeld door het individu dat de beurt heeft.

c. leerpunt 5 erop gericht is de betreffende client zijn manier te laten uitkiezen uit de tot nu toe geinventariseerde mogelijkhedem alsook de gekozen mogelijkheid concretiseren in tijd, plaats, betrokken personen, e.d.

d. wat leerpunt 6 betreft, geoefend wordt in het anticiperen op mogelijke tegenslag door bij voorbaat oplossingen daarvoor te bedenken.

e. leerpunt 4,5 en 6 wordt toegepast op dezelfde veranderingen als in zitting 1 .

$1.50-1.60$ u. HUISWERK

Alle deelnemers krijgen de opdracht leerpunt 4,5 en

6 toe te passen op de huiswerksituatie uit zitting 1 .

ZITTING 3

$0.00-0.40$ u. HUISWERKBESPREKING

Deze verloopt conform zitting 2 .

$0.40-0.70$ u. VIDEO-MODELING EN DIDACTISCHE INSTRUCTIES

1. De video-modeling verloopt conform zitting 1 en 2.

2. De therapeuten geven duidelfjk aan dat nu fase 3 uit het veranderingsproces aan de orde is, $n 1$. het "aan de slag gaan". De therapeuten lichten toe hoe deze fase logisch en consequent voortvloeit uit de eerder behandelde doelstellings- en planningsfase. 
$0.70-1.10$ U. GEDRAGSOEFENING

Deze verloopt conform zitting 1 en 2 . De leerpunten 7,8 en 9 worden nu ingeoefend met betrekking tot dezelfde veranderingen als in zitting 1 en 2 .

1.10 - 1.20 u. HUISWERK

Alle deelnemers krijgen de opdracht leerpunt $7,8,9$ toe te passen op de hul swerksituatie uit zitting 1 en 2.

ZITTING $4 \mathrm{~T} / \mathrm{M} 7$

Mutatis Mutandis geldt hier dat er steeds sprake is van:

* HUISWERKNABESPREKING: $0.00-0.40 u$.

* Gedragsoefening : $0.40-1.50 \mathrm{u}$.

* HUISWERKOPDRACHT : $1.50-1.60 \mathrm{u}$.

Nadat de deelnemers leerpunt $1 \mathrm{t} / \mathrm{m} 9$ hebben doorgewerkt, beginnen ze opnieuw bij leerpunt 1 . De leerpuntensequentie wordt tijdens deze zittingen meerdere malen achter elkaar doorgewerkt, waarbij geldt dat elke deelnemer hierbij zijn eigen tempo aanhoudt. Zodoende kunnen de verschillende deelnemers tijdens een en dezelfde bijeenkomst verschillende fasen uit het veranderingsproces inoefenen. De therapeuten laten, aan de hand van een voorbeeld van een van de deelnemers zien, dat het noodzakelijk kan zijn de leerpuntensequentie meerdere malen achter elkaar toe te passen teneinde een en dezelfde verandering tot stand te brengen (=werken met subdoelen).

Het is bovendien van belang dat de therapeuten erop toezien dat de deeinemers in de loop van de tijd de leerpunten uit het hoofd leren zonodig met behulp van didactische hulpmiddelen in de vorm van ezelsbruggetjes, speelse repitities in de groep, het benutten van transitional objects etc. 
Nadat in de viffde zitting de socratische dialoog tussen therapeut en client nogmals expliclet aan de deelnemers is gemodeld door de therapeuten, wordt deze vervolgens steeds door $2 \mathrm{clienten}$ uit tgevoerd. De socratische dialoog is gericht op verheldering van de denkstappen die bij "veranderingen aanpakken" een rol spelen.

In de zesde of zevende zitting wordt video-voorbeeld 4 aan de deelnemers getoond, waarin de leerpunten 1 $\mathrm{t} / \mathrm{m} 9$ in een vloeiende $11 \mathrm{jn}$ worden toegepast door een jonge vrouw, op zoek naar een partner.

\section{ZITTING 8}

$0.00-0.40 \mathrm{u}$. HUISWERKBESPREKING

Conform zitting 2 .

$0.40-1.40$ u. GEDRAGSOEFENING

Conform zitting 2 .

$1.40-1.60$ u. HUISWERK

In de laatste zitting wordt met elke deel nemer afzonderlijk "continue" huiswerk afgesproken. Op deze wijze tracht men te bewerkstelligen dat de deelnemers de nieuw aangeleerde vaardigheid blijven stellen in hun dagelijkse levenssituatie ook nadat de groepsbijeenkoms ten zijn a fgelopen. 
Bijlage III: De DH-1 ijst

1. Door tegenslag laat ik mij

a volledig uit het veld slaan

0 wel wat wit het veld slaan

0 vrijwel niet uit het veld slaan

2. Als ik moet kiezen, zit ik

0 meestal te 1 ang te wikken en te wegen

0 regelmatig te lang te wikken en te wegen

0 vrijwel mooit te lang te wikken en te wegen

3. Problemen zijn me

D vrijwel altijd de baas

0 soms de baas

o vrijwel nooit de baas

4. Als er een probleem is, zie ik daar

o vrijwel altijd tegenop

0 soms tegenop

o vrijwel nooit tegenop

5. Door problemen laat ik mij

0 vaak on tmoedigen

a soms ontmoedigen

0 bijna nooit on tmoedigen

6. Als er problemen zijn, ben ik nergens meer.
0 waar
0 enigszins waar
0 niet waar

7. Ik zit gauw bij de pakken neer.
0 waar
0 enigszfins war
0 niet war 
8. Ik kan goed knopen doorhakken.

0 war

0 enigszins waar

0 niet waar

9. Plannen maken

0 vind ik nuttig

0 vind ik niet 20 erg nuttig

0 vind ik helemaal niet nuttig

10. Ik maak

0 vaak plannen

0 soms plannen

0 vrijwel nooit plannen

11. Ik denk

0 vaak na voordat ik ergens aan begin

a soms na voordat ik ergens aan begin

0 bijna nooit na voordat ik ergens aan begin

12. Als ik aan iets moeilijks begin, bedenk ik

0 meestal vooraf hoe ik het ga aanpakken

0 soms vooraf hoe ik het ga aanpakken

0 bijna nooit vooraf hoe ik het ga aanpakken

13. Ik denk

0 vaak vooruit

0 soms voorult

o bijna nooit vooruit

14. Als lets me niet bevalt, dan doe ik daar

0 vrijwel altijd iets aan

0 soms iets aan

0 vrijwel nooit iets aan

15. Als ik een beslissing moet nemen, dan doe ik dat

0 meestal te 1 aat

0 soms te laat

0 vrijwel nooit te laat 
16. Van mijn goede voornemens komt

o vrijwel nooit iets terecht

0 zo nu en dan wèl iets terecht

0 vrijwel altijd iets terecht

17. A1s ik jets van plan ben, dan

0 doe ik dat meestal ook

0 doe ik dat soms ook

0 doe ik dat eigenlijk nooit

18. A1s ik ergens aan begin

o maak ik dat ook af

0 mak ik dat soms niet af

0 maak ik dat bijna nooit af

19. Moeilijke dingen stel ik
0 vrijwel altijd uit
0 soms uit
o vrijwel nooit uit

20. Tegen het leven van alledag voel ik me
0 niet opgewassen
0 niet zo best opgewassen
0 best opgewassen

21. Ik ben iemand die

0 vrijwel altijd wel weer op zijn pootjes terecht komt

0 vaak weer op zijn pootjes terecht komt

0 bijna nooft weer op zijn pootjes terecht komt

22. Als ik iets moet weten, zorg ik

0 meestal dat $i \mathrm{k}$ er ook achter kom

o vaak dat ik er ook achter kom

0 vrijwel nooit dat ik er ook achter kom

23. Ik heb mijn leven

0 vrijwel altijd zelf in de hand

0 soms zelf in de hand

0 vrijwel nooit zelf in de hand 
24. Ik heb

0 veel vertrouwen in de toekomst

0 wel enig vertrouwen in de toekomst

0 geen vertrouwen in de toekomst

25. De dingen lopen

0 meestal anders dan ik gedacht had

0 soms anders dan $i k$ gedacht had

o vrifwel noolt anders dan ik gedacht had

26. Op een eenmaal genomen besluit

0 kom ik biljna nooft terug

0 kom ik regelmatig terug

0 kom ik bijna altijd terug

27. Ik ga

- bijna altijd te impulsief tot actie over

0 soms te impulsief tot actie over

0 bijna nooit te impulsief tot actie over

28. Een mens is nooft te oud om te leren.
0 waar
0 enigszins waar
0 niet waar

29. Mij zit altijd alles tegen.
0 waar
0 enigszins waar
0 niet waar

30. Met gezond verstand kom je een heel eind.
0 waar
0 enigszins waar
0 niet waar

31. Als ik iets persë wil, dan lukt me dat ook altijd.
0 waar
0 enfigszins waar
0 niet waar 
32. Ik handel vaak als een kip zonder kop.
0 waar
o enigszins waar
0 niet waar

33. Als de dingen niet precies gaan zoals ik gedacht had, houd ik er 1i ever meteen mee op.
0 waar
0 enigszins waar
o niet waar 


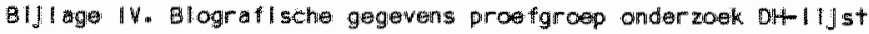

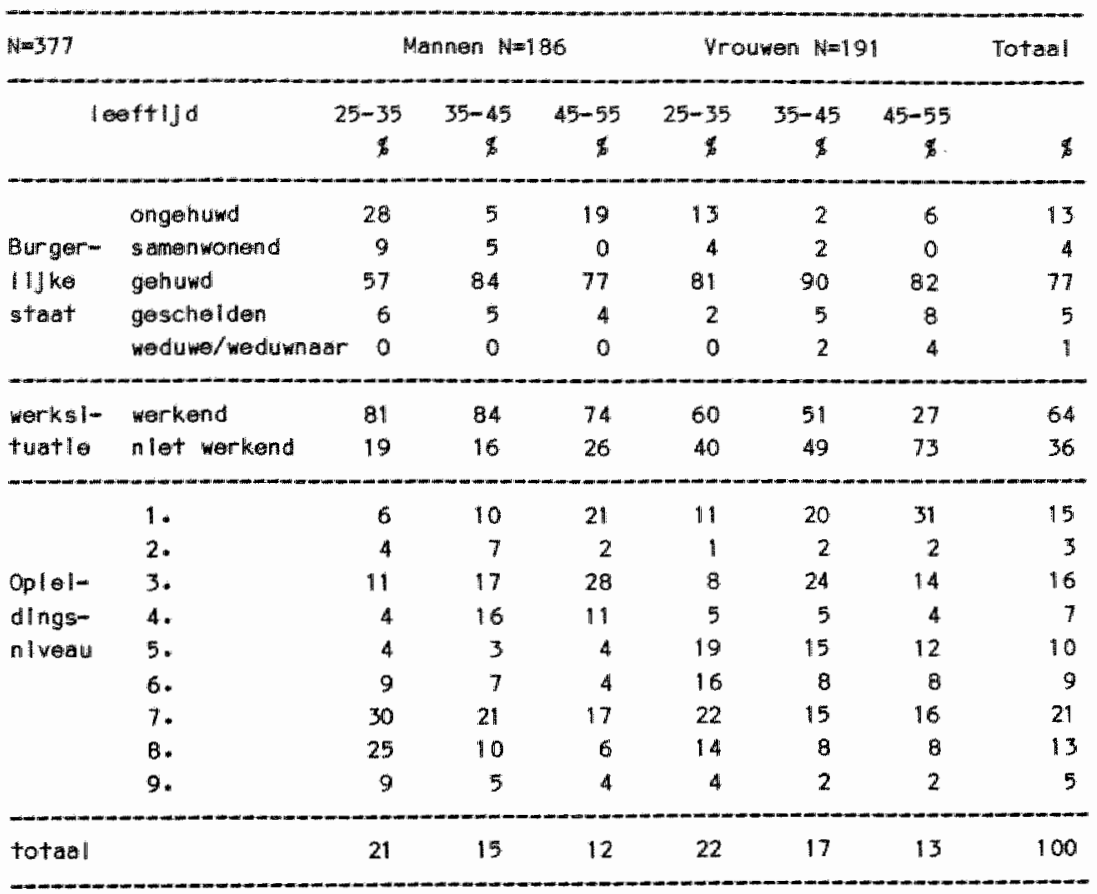

Toollchting bill bovenstaande tabel:

- de categor le nlet-werken anvat tevens de submcategorlean hilswrouw, W. W., W.H.V., A.0.H., A.A.W., Zlektewet en anderszlins.

- het opleldingsnlveau werd Ingedeelld conform de NIJmeegse beroepenklapper (Van Wasterllazk, Kropman, Collarlsi, 1975) in de wolgende 9 nlweau"s:

1. LO of VGLO/LAVO of en Ige Jaren ULO/MAVO zonder meer

2. LO of VGLORLAVO of enIge Jaren ULO/MAVO pI US specit leke part-time opleldiling

3. dlplom lager beroepsonderwlis of primalre hul shoudschool zonder meer

4. diploma lager beroepsonderwijs of primalre hulshoudschool plus specl fleke pertwitime oplolding

5. dlploni ULO/MAVO of en ige Jaren VHMO zonder meer

6. diploma ULO/MAVO of enlge Jaran VHMO plus speclt leke part-time opleilding

7. diplome WHMo of middelbar bercepsonderw IJs

8. Alplong hoger beroopsonder $1 \mathrm{~s}$

9. dlplome universitelt of mogeschool. 
Aan het werk dat aan dit proefschrift ten grondslag ligt, hebben velen bijgedragen.

All ereerst wil ik mijn promotor Prof. Dr. J.J.C.B. Bremer en co-promotor $\mathrm{Dr}$. M. Beekers bedanken voor hun begeleiding en ondersteuning bij het tot stand komen van dit proefschrift.

Jos Bongaarts, AnneMieke Brands, Jan Gooijen, Leo Maassen en Martha Moonen dank ik voor hun steun en inzet als medeprojectgroepsleden. Jan van Houtem voor zijn bijdrage aan de data-verwerking.

AnneMieke Brands, Carla Colner, Lilian Houben, Gemma Janssen en Martha Moonen leverden een belangrijke bijdrage aan de data-verzameling. Van de Toneelacademie dank ik Jacques Giessen, Pieter Hoes, Doc Janssen, Clement Mantz, Leo Maassen, Sjef Troisfontaine en ook een aantal studenten voor hun bijdrage aan het tot stand komen van de video-programma's.

Georges Crolla, Jan Peumans, Irene Pijnenburg, Jan Schijen en de medewerkers van de afdeling $k 7 i n i s c h e$ gedragstherapie van het Psychomedisch Streekcentrum Vijverdal ben ik erkentelijk voor hun aandeel bij de uitvoering van de persoonlijke vaardigheidstherapieën.

Isel van Noppen dank $1 k$ voor de wijze waarop $z i j$ alle typewerk verzorgde: accuraat, zorgzaam, onvermoeibaar en steeds opgewekt. Op de meest onmogelijke tijden kon ik bij haar terecht on dingen op te halen en afspraken te maken. $Z i j$ was altijd weer bereid de vereiste aanpassingen in het manuscript aan te brengen.

Voorts will ik de referenten - Prof. Dr. R. Diekstra, Prof. Dr. H. Philipsen en Prof. Dr. M. Romme - bedanken voor de wijze waarop zij dit proefschrift beoordeelden. En natuurlijk ook alle respondenten die aan dit onderzoek hebben meegewerkt.

Jos Peters dank ik omdat hij de basis schiep waarop de Goldsteinprojectgroep tot ontwikkeling kon komen.

Last but not least wil ik mijn ouders bedanken, omdat zij degenen zijn die al mijn studies mogelijk maakten. 
Bea Beckers werd op 26 apri1 1952 geboren in Heugem (gemeente Maastricht). Na het behalen van haar gymnasium $\alpha$ diploma aan het Jeanne D'Arc Lyceum te Mastricht, studeerde zij psychologie aan de Katho1 leke Universiteit te Nijmegen. In juni 1978 behalde ze haar doctoraalexamen klinische psychologie. Haar doctoraall-scriptie had betrekking op het onderwerp psychotherapie en "lower class". Van september 1978 tot 1 jul 11984 was ze als wetenschappelijk medewerkster in tijdelijke dienst verbonden aan het Goldsteinproject van de afdeling Medische Psychologie van de Rijksuniversiteit Limburg. Het Goldsteinproject (1977-1985) was een project waarin medewerkers van de Rijksuniversiteit Limburg, de Toneelacademie Mastricht en de RIAGG's Heerlen en Maastricht samenwerkten aan de ontwikkeling van een kortdurende psychotherapiemethode voor clienten uit de lagere sociaal-econo$\mathrm{mi}$ sche klassen.

Tussen 1978 en 1984 volgde ze diverse postdoctorale psychotherapieopleidingen. Dit leidde inmiddels tot erkenningen als gewoon lid van de Vereniging voor Gedragstheraple alsook de Nederlandse Vereniging voor Psychotherapie. Ook behaalde ze haar registratie als klinisch psychologe en als psychologe/psychotherapeute bij het NIP. In maart 1985 werd ze als supervisor erkend door de Vereniging voor Gedragstherapie.

Sinds $j u l i f 1984$ is ze als $k 1$ inisch psychologe/gedragstherapeute verbonden aan de afdeling psychotherapie van het RIAGG te Heerlen. 